\title{
The latest process and challenges of microwave dielectric ceramics based on pseudo phase diagrams
}

\author{
Hongcheng YANG ${ }^{a, b}$, Shuren ZHANG ${ }^{a, b}$, Hongyu YANG $^{a, b}$, Qingyu WEN ${ }^{a, b}$, \\ Qiu YANG ${ }^{a, b}$, Ling GUI ${ }^{a, b}$, Qian $\mathrm{ZHAO}^{a, b}$, Enzhu LI ${ }^{a, b, *}$ \\ ${ }^{a}$ National Engineering Research Center of Electromagnetic Radiation Control Materials, \\ University of Electronic Science and Technology of China, Chengdu 610054, China \\ ${ }^{b}$ Key Laboratory of Multi-Spectral Absorbing Materials and Structures of Ministry of Education, \\ University of Electronic Science and Technology of China, Chengdu 610054, China
}

Received: April 28, 2021; Revised: June 4, 2021; Accepted: June 6, 2021

(C) The Author(s) 2021.

\begin{abstract}
The explosive process of 5G communication evokes the urgent demand of miniaturized and integrated dielectric ceramics filter. It is a pressing need to advance the development of dielectric ceramics utilization of emerging technology to design new materials and understand the polarization mechanism. This review provides the summary of the study of microwave dielectric ceramics (MWDCs) sintered higher than $1000{ }^{\circ} \mathrm{C}$ from 2010 up to now, with the purpose of taking a broad and historical view of these ceramics and illustrating research directions. To date, researchers endeavor to explain the structure-property relationship of ceramics with multitude of approaches and design a new formula or strategy to obtain excellent microwave dielectric properties. There are variety of factors that impact the permittivity, dielectric loss, and temperature stability of dielectric materials, covering intrinsic and extrinsic factors. Many of these factors are often intertwined, which can complicate new dielectric material discovery and the mechanism investigation. Because of the various ceramics systems, pseudo phase diagram was used to classify the dielectric materials based on the composition. In this review, the ceramics were firstly divided into ternary systems, and then brief description of the experimental probes and complementary theoretical methods that have been used to discern the intrinsic polarization mechanisms and the origin of intrinsic loss was mentioned. Finally, some perspectives on the future outlook for high-temperature MWDCs were offered based on the synthesis method, characterization techniques, and significant theory developments.
\end{abstract}

Keywords: high-temperature microwave dielectric ceramics (MWDCs); pseudo phase diagram; developments and challenges; composition-structure-property relationship

\section{Introduction}

Over the past half century, semiconductor integration

\footnotetext{
* Corresponding author.

E-mail: lienzhu@uestc.edu.cn
}

technology has become one of the most far-reaching and significant technological innovations in human society. The rapid development of this technology has enabled mankind to enter today's information society. However, semiconductor devices as active devices are only part of the electronic components. Another part of 
the huge amount and a wide variety of components with different functions are passive devices. The core materials of these components are various types of functional ceramic materials. Microwave dielectric ceramics (MWDCs) are the pivotal component of a passive device, which are mainly used as filters, resonators, RF antennae, frequency discriminators in electronic countermeasures, navigation, radar, home satellite live television receivers, and hand-held mobile phones. The applications of MWDCs in different frequency are directly plotted in Fig. 1. However, the development of microwave ceramics had gone through a sluggish procession because of the lack of suitable materials for dielectric resonator. The discovery of rutile (also known as titanium dioxide ceramics) in the 1970s makes it possible to synthesis dielectric resonator [1]. Various literature has been reported to explore the potential candidates of MWDCs after that, from single oxide, binary oxide, to ternary oxide. According to the data in the Web of Science, over 1000 papers were published about MWDCs around the world after 2000.
Figure 2 presents the trend of published papers where more than $30 \%$ of investigations belong to China.

To evaluate the dielectric properties of ceramics, the relative permittivity $\left(\varepsilon_{\mathrm{r}}\right)$, dielectric loss (loss tangent or quality factor $(Q \times f$ value)), and temperature coefficient of resonant frequency $\left(\tau_{\mathrm{f}}\right)$ are the three pivotal characteristics. As early as in 2006, the direction of development of microwave dielectric materials has been highlighted by Ohsato et al. [2], including high $Q$ and low $\varepsilon_{\mathrm{r}}$ ceramics for millimeter-wave application, high $Q$ and high $\varepsilon_{\mathrm{r}}$ ceramics for base station, and high $\varepsilon_{\mathrm{r}}$ ceramics for miniaturization of mobile phone. Up to now, researchers have explored hundreds of ceramics to enrich the database of MWDCs, but only a dozen of those ceramics with unique properties have been commercially used to fabricate relevant devices because most of the ceramics lack stability or generate large loss in the electronic components. Booming development of millimeter technology and $5 \mathrm{G}$ communication have rendered a new round of requirement of MWDCs of low permittivity with a stable dielectric loss in the scope

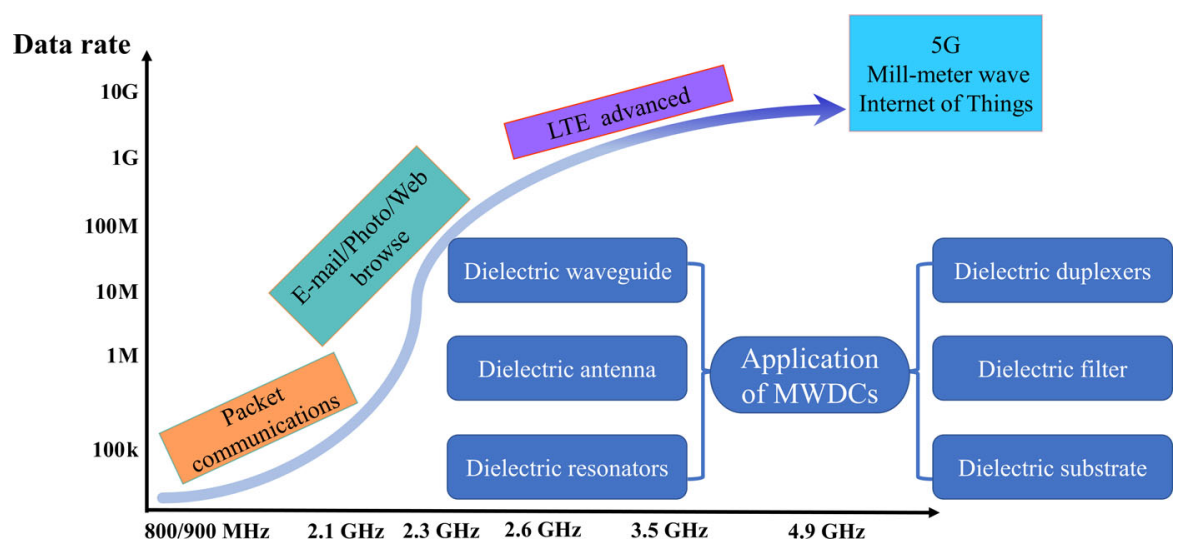

Fig. 1 Applications of MWDCs in different frequencies.
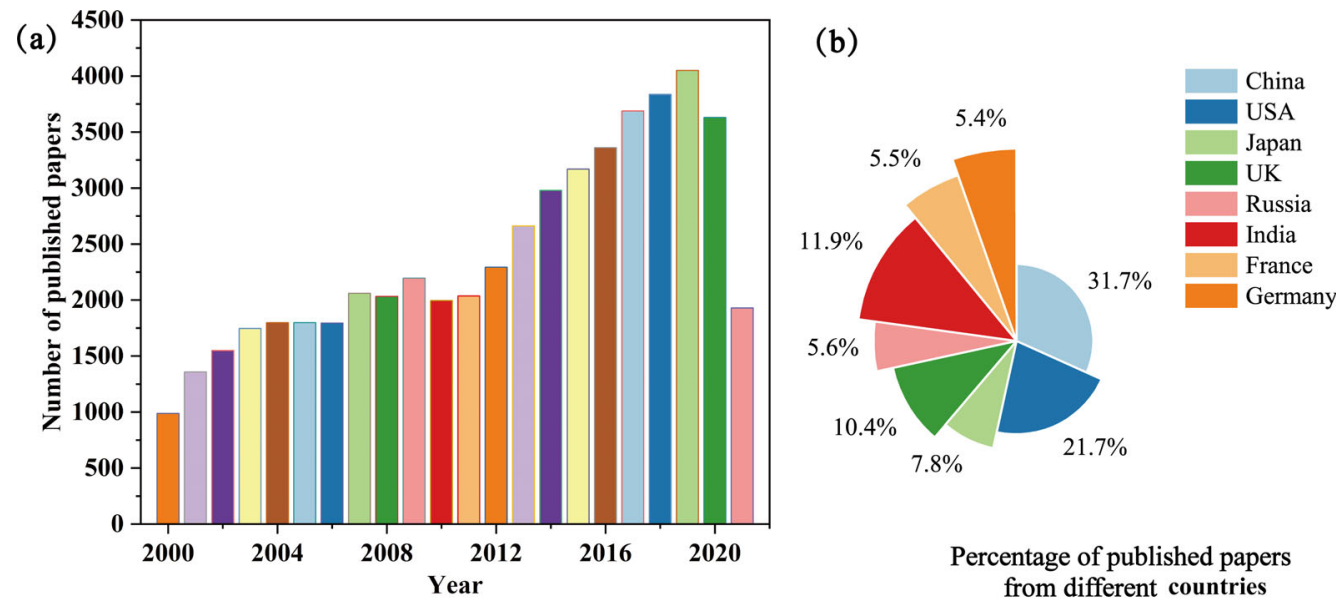

Fig. 2 (a) Number of published papers about MWDCs from 2000 and (b) percentage of published papers from different countries. 
of frequency up to $100 \mathrm{GHz}$. Especially, the emergency of COVID-19 makes video conferencing and telecommuting as a daily part in our lives. Consequently, the unprecedented growth of global data volume and huge demand for high data rates urge researchers to search more alternative materials for commercial electronic market. It is also a very significant issue for the industry to yield ceramics with ultra-low permittivity which are suitable for $5 \mathrm{G}$ and $6 \mathrm{G}$ communication system. However, it is still a "try and error" state in our experiments for discovering materials or optimizing the properties of the reported ceramics. The main difficulty in the development of MWDCs is to understand the fundamental relationship of compositionstructure-property and draw general trends throughout the field, after normalizing and comparing the various results. Despite long-term sustained attempts, there is no systematic or comprehensive theory which can provide common guidance in the experiments and drive currently reported ceramics toward commercialization applications.

With the exploration of MWDCs clusters and the development of modern experiment techniques, investigations about MWDCs have been largely scoped by the designs and search for new systems and reoptimizing their properties. It is paramount that an MWDCs candidate has an appropriate dielectric constant, low dielectric loss, and near-zero temperature coefficient of resonant frequency for applications. Generally, to tune the microwave dielectric properties, there are two parts that should be taken into consideration (extrinsic and intrinsic parts). Extrinsic part is usually regarded as the influence originated from the synthesis method and raw materials. MWDCs usually prepare by solid state reaction method, and the sintering conditions directly influence the microstructure and compactness of ceramics, which subsequently affect the microwave dielectric properties. Meanwhile, the selectivity of size distribution, purity, non-stoichiometric ratio, species of different compounds, and pretreatment of raw materials based on their physical and chemical properties are crucial for reaching optimal microwave dielectric properties. For example, the procedures to reduce pores are designed for ceramics containing the volatile element, evolving non-stoichiometric ratio in the chemical formula, and providing the compensation atmosphere of volatile element. The relevant attempts are mostly discussed for the rock salt structure ceramics such as $\mathrm{Li}_{2} \mathrm{Mg}_{3} \mathrm{TiO}_{6}$. Besides, various synthesis methods, namely sol-gel method, sink plasma sintering method, and high energy ball-milling method are gradually used for preparing the MWDCs, and numbers of studies analyze the discrepancy of microwave dielectric properties obtained with different methods. The intrinsic part stems from anharmonic lattice vibration, which primarily generates large dielectric loss. As yet, there is no technology or theory that could feasibly adjust the anharmonic lattice vibration to reduce dielectric loss. In the experiment, after carefully controlling the sintering conditions and selecting raw materials, the most pragmatic approach to optimize the properties is cation substitution with the consideration of the radii and the electronegativity of cations, contributing to reducing the dielectric loss or modifying the temperature coefficient of resonant frequency. Near-zero temperature coefficient of resonant frequency is also obtained by designing co-exited phase system with introduction of two ceramics with opposite $\tau_{\mathrm{f}}$ values, but the composite ceramics may lead to a poor $Q \times f$ value. More recently, the strategy of tri-layer structures of $\mathrm{Zn}_{1.01} \mathrm{Nb}_{2} \mathrm{O}_{6} / \mathrm{TiO}_{2} / \mathrm{Zn}_{1.01} \mathrm{Nb}_{2} \mathrm{O}_{6}$ [3], $\mathrm{MgTiO}_{3} / \mathrm{TiO}_{2} / \mathrm{MgTiO}_{3}$ [4], and $\mathrm{Zn}_{3} \mathrm{Nb}_{2} \mathrm{O}_{8} / \mathrm{TiO}_{2} /$ $\mathrm{Zn}_{3} \mathrm{Nb}_{2} \mathrm{O}_{8}$ [5] were verified as a method to obtain the temperature-stable ceramics with low dielectric loss.

Currently, the database of MWDCs is enriched by insightful information about the structure and properties, and the growing number of literature converts from description of phenomena to explanation of the theoretical mechanism of the dielectric materials. Thorough and comprehensive investigation of ceramics is gradually presented to estimate the extrinsic and intrinsic influence on the microwave dielectric properties. For instance, the common discussion of polarization mechanism is usually based on the ionic polarization, where the Clausius-Mossotti (C-M) equation is applied to evaluate the discrepancy of theoretical $\varepsilon_{\mathrm{r}}$ and measured $\varepsilon_{\mathrm{r}}$. The popularization of Rietveld-refinement in the literature supports the analysis of lattice parameters, packing fraction, and chemical bond characteristic obtained by the complex chemical bond theory $(\mathrm{P}-\mathrm{V}-\mathrm{L})$ theory. Especially, disassembling the crystal into the sum of sample binary compound based on the crystal parameters and coordinate numbers of each ions [6], the investigations about application of $\mathrm{P}-\mathrm{V}-\mathrm{L}$ theory into multi-type structure emerge in abundance. The origin of dielectric loss is quantified by lattice vibrational spectroscopy, and the contribution of each chemical bond to the microwave dielectric 
properties is verified by $\mathrm{P}-\mathrm{V}-\mathrm{L}$ theory. For some unique ceramics, researchers bend themselves to exploring the underlying mechanism for the observed phenomenon. The influence of long-range movement of charged defects in the grain and grain boundary was estimated by the impedance analysis, terahertz (THz) time-domain spectroscopy analysis, and the electron paramagnetic resonance spectra, which can explain the defect generation mechanism in doped $\mathrm{Li}_{2} \mathrm{ZnTi}_{3} \mathrm{O}_{8}$ ceramics. The analysis of disordered-ordered crystal structure evolution and super-lattice in rock salt ceramics and complex perovskite ceramics gives evidence to explain the ultra-low dielectric loss. Both the development of experimental and theoretical method allows us to summarize the relevant experimental probes of different systems and propose the challenges and prospects of MWDCs.

While many great review and perspective articles have been published about MWDCs, they have finished the review by classified MWDCs based on the criteria of sintering temperature, dielectric constant, and crystal structure [1,7-9]. Furthermore, the early works before 2010 are mainly concentrated on the description of phase composition, micrographic images, and variation of microwave dielectric properties. The topic about the MWDCs sintered lower than $950{ }^{\circ} \mathrm{C}$ is especially focused owing to the advantages of low-temperature co-fired ceramics (LTCC) technology where this approach guarantees the integration of electronic components. Considering either the timespan or topic covered, the mentioned ceramics, in this review, are all sintered higher than $1000{ }^{\circ} \mathrm{C}$. The LTCC system including ceramics with a few sintering aids, glass-ceramics system, or glass-free system is not referred. To follow the development of new analysis methods, MWDCs, beginning with the first reported properties and upgrading the relevant references after 2010, were included. Additionally, because of so various structures and properties of MWDCs, pseudo phase diagram was used to classify the ceramics according to the composition, which will serve as the basis and link for each pseudo phase diagram of diversity composition. The organization of this review consists of a brief section detailing the phase evolution or structure transformation of oxide ceramics in the designed pseudo phase diagram, and then the chronological experimental probes for a unique system are summarized.

\section{Phase diagram}

The phase diagram is a visual representation of the phase equilibrium, which defines the composition of multiphase system. It is an efficient and convenient technique to analyze the composition and their proportion, which plays a significant role in guiding the research and exploration of materials to reduce the manpower and material resources effectively. This section provides a broad context by summarizing the ceramics system based on pseudo phase diagram, and all the composition in the following pseudo phase diagram is in molar ratio. The endpoint of each pseudo phase diagram contains more than one component, and the labelled ceramics are the primary system reported by researchers. The summary of investigations in the same general formal is listed in detail.

\section{1 Silicate and germanate}

There is a low $\varepsilon_{\mathrm{r}}(<10)$ for silicates, owing to the low ionic polarizability of $\mathrm{Si}^{4+}$ and half covalent bond in $\mathrm{Si}-\mathrm{O}$. In the binary silicate, the $\mathrm{CaSiO}_{3}, \mathrm{Mg}_{2} \mathrm{SiO}_{4}$, $\mathrm{Zn}_{2} \mathrm{SiO}_{4}$, and $\mathrm{Re}_{2} \mathrm{SiO}_{5}$ are the main representatives, where $\mathrm{CaSiO}_{3}$ usually appeared as the crystalized phase in $\mathrm{CaO}-\mathrm{B}_{2} \mathrm{O}_{3}-\mathrm{SiO}_{2}$ glass. Ternary silicate such as diopside-type $\mathrm{CaMgSi}_{2} \mathrm{O}_{6}$, melitile-type $\mathrm{A}_{2} \mathrm{BC}_{2} \mathrm{O}_{7}$ and $\mathrm{AB}_{2} \mathrm{C}_{2} \mathrm{O}_{7}(\mathrm{~A}=\mathrm{Sr}, \mathrm{Ca}, \mathrm{Ba} ; \mathrm{B}=\mathrm{Mg}, \mathrm{Zn}, \mathrm{Co}, \mathrm{Mn}$, $\mathrm{Cu}$ ), and cuspidine-type $\mathrm{Ca}_{3} \mathrm{SnSi}_{2} \mathrm{O}_{9}$ were highlighted by researchers, due to the diverse crystal structures in those systems. With the wake of exploration of new ceramics, the germanate gradually occurred as a candidate material with low dielectric loss despite of the expensive cost of $\mathrm{GeO}_{2}$ as raw material. The pseudo phase diagram of the silicate and germanate is presented in Fig. 3, where the primary phases of binary and ternary silicate and germanate are listed in the phase diagram.

\subsubsection{Binary silicate ceramics}

Synthesis of dense $\mathrm{SiO}_{2}$ ceramic is challengeable because of its complexity in polymorphs and phase transitions. Until 2012, microwave dielectric properties of $\mathrm{SiO}_{2}$ ceramic were reported as $\varepsilon_{\mathrm{r}} \approx 3.81, Q \times f$ value $\approx$ $80,400 \mathrm{GHz}$, and $\tau_{\mathrm{f}} \approx-16.1 \mathrm{ppm} /{ }^{\circ} \mathrm{C}$, sintered at $1650{ }^{\circ} \mathrm{C}$ for $3 \mathrm{~h} \mathrm{[10]}$. After that, Li et al. [11] illustrated that $0.84 \mathrm{SiO}_{2}-0.16 \mathrm{TiO}_{2}$ composite ceramics possessed satisfied properties of $\varepsilon_{\mathrm{r}} \approx 5.91, Q \times f$ value $\approx 39,680 \mathrm{GHz}$, and $\tau_{\mathrm{f}} \approx-4.5 \mathrm{ppm} /{ }^{\circ} \mathrm{C}$, sintered at $1275{ }^{\circ} \mathrm{C}$ for $3 \mathrm{~h}$. 


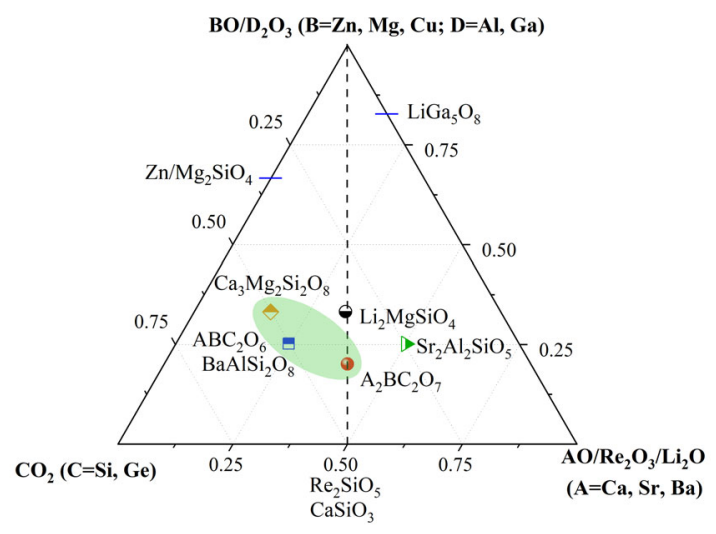

Fig. 3 Pseudo phase diagram of the silicate and germinate.

Comparing to the difficulty of preparing compact $\mathrm{SiO}_{2}$ ceramic, the restriction of preparing dense $\mathrm{CaSiO}_{3}$ ceramic stemmed from the narrow sintering temperature range of pure $\mathrm{CaSiO}_{3}$ and the porous microstructure [12]. Commonly, $\mathrm{CaSiO}_{3}$ was reported as a main phase in the $\mathrm{CaO}-\mathrm{B}_{2} \mathrm{O}_{3}-\mathrm{SiO}_{2}$ glass-ceramic system, which primarily determined the properties. There are two main phases of $\mathrm{CaSiO}_{3}$, containing low-temperature wollastonite $\left(\alpha-\mathrm{CaSiO}_{3}\right)$ and hightemperature preudo-wollastonite $\left(\beta-\mathrm{CaSiO}_{3}\right)$. Through a sol-gel method, the microwave dielectric properties of $\alpha-\mathrm{CaSiO}_{3}$ are: $\varepsilon_{\mathrm{r}} \approx 6.69, Q \times f$ value $\approx 25,398 \mathrm{GHz}$, sintered at $1320{ }^{\circ} \mathrm{C}$ [13]. In order to improve the microwave dielectric properties, $\left(\mathrm{Ca}_{1-x} \mathrm{Mg}_{x}\right) \mathrm{SiO}_{3}$ ceramics with $x=0.1,0.5,0.9$ were verified as single phases, and properties of $\varepsilon_{\mathrm{r}} \approx 6.49, Q \times f$ value $\approx 62,420 \mathrm{GHz}$, and $\tau_{\mathrm{f}} \approx-43.3 \mathrm{ppm} /{ }^{\circ} \mathrm{C}$ were obtained when sintered at $1320{ }^{\circ} \mathrm{C}$ with $x=0.1$ [14]. Besides, the investigation of $\mathrm{CaSiO}_{3}-\mathrm{Al}_{2} \mathrm{O}_{3}$ ceramics revealed that the secondary phases of $\mathrm{Ca}_{2} \mathrm{Al}_{2} \mathrm{SiO}_{7}$ and $\mathrm{CaAl}_{2} \mathrm{Si}_{2} \mathrm{O}_{8}$ would deteriorate the microwave dielectric properties with excessive $\mathrm{Al}_{2} \mathrm{O}_{3}$ [15,16]. According to $\mathrm{Hu}$ et al. [17], the phase transformation of $\mathrm{CaSiO}_{3}$ was inhibited with the increase of $\mathrm{SiO}_{2}$ content, and $\alpha-\mathrm{CaSiO}_{3}-2 \mathrm{wt} \% \mathrm{Al}_{2} \mathrm{O}_{3}-$ $2.5 \mathrm{wt} \% \mathrm{TiO}_{2}$ shows excellent properties of $\varepsilon_{\mathrm{r}} \approx 7.88$, $Q \times f$ value $\approx 24,412 \mathrm{GHz}$, and $\tau_{\mathrm{f}} \approx-0.52 \mathrm{ppm} /{ }^{\circ} \mathrm{C}$ [18]. To obtain compact ceramics, $\mathrm{SnO}_{2}$-doped $\alpha$-CaSiO 3 ceramics with $\varepsilon_{\mathrm{r}} \approx 9.27, Q \times f$ value $\approx 53,000 \mathrm{GHz}$, and $\tau_{\mathrm{f}} \approx-52 \mathrm{ppm} /{ }^{\circ} \mathrm{C}$ sintered at $1450{ }^{\circ} \mathrm{C}$ were reported in a relative density higher than $97 \%$ [19].

With a $Q \times f$ value larger than $100,000 \mathrm{GHz}$, another class of binary silicate can be written as $\mathrm{A}_{2} \mathrm{SiO}_{4}(\mathrm{~A}=$ $\mathrm{Ba}, \mathrm{Sr}, \mathrm{Ca}, \mathrm{Mg}, \mathrm{Zn}$ ) [20-23]. Forsterite $\mathrm{Mg}_{2} \mathrm{SiO}_{4}$ is extensively explored because of its superior microwave dielectric properties $\left(\varepsilon_{\mathrm{r}} \approx 7.8, Q \times f\right.$ value $\approx$
$240,000 \mathrm{GHz}$, and $\tau_{\mathrm{f}} \approx-67 \mathrm{ppm} /{ }^{\circ} \mathrm{C}$, sintered at 1450 $\left.1500{ }^{\circ} \mathrm{C}\right)[2,24,25]$. Nevertheless, the high sintering temperature and large $\tau_{\mathrm{f}}$ value inhibit its application. To adjust $\tau_{\mathrm{f}}$ value, both co-exited phase of $\mathrm{Mg}_{2} \mathrm{SiO}_{4}-\mathrm{Ca}_{0.9} \mathrm{Sr}_{0.1} \mathrm{TiO}_{3}$ [26] and $\mathrm{Zn}_{2} \mathrm{SiO}_{4}-\mathrm{TiO}_{2}$ [27] contributed to a near-zero $\tau_{\mathrm{f}}$ value. Melting $\mathrm{CuO}$ could enhance the sintering procession of $\mathrm{Zn}_{2} \mathrm{SiO}_{4}$, and the quality factor reached $105,500 \mathrm{GHz}$ when sintered at $1150{ }^{\circ} \mathrm{C}$ [28]. Zn-deficient formula was verified valid to suppress the formation of secondary phase in $\mathrm{Zn}_{2} \mathrm{SiO}_{4}$ ceramics, and $\mathrm{Zn}_{1.8} \mathrm{SiO}_{3.8}$ was estimated with properties of $\varepsilon_{\mathrm{r}} \approx 6.451, Q \times f$ value $\approx 102,807 \mathrm{GHz}$, and $\tau_{\mathrm{f}} \approx-32$ $\mathrm{ppm} /{ }^{\circ} \mathrm{C}$, sintered at $1300{ }^{\circ} \mathrm{C}[29]$.

After predicting the permittivity of $\mathrm{ZrO}_{2}-\mathrm{SiO}_{2}$, $\mathrm{HfO}_{2}-\mathrm{SiO}_{2}, \mathrm{La}_{2} \mathrm{O}_{2}-\mathrm{SiO}_{2}$, and $\mathrm{Y}_{2} \mathrm{O}_{3}-\mathrm{SiO}_{2}$, those systems were clarified as an alternative of dynamic random access memory capacitor dielectric materials [30]. The exploration of properties of $\mathrm{Sm}_{2} \mathrm{SiO}_{5}$ and $\mathrm{Nd}_{2} \mathrm{SiO}_{5}$ ceramics compensated the absence of study on microwave dielectric properties of $\mathrm{Re}_{2} \mathrm{O}_{3}-\mathrm{SiO}_{2}$, where the microwave dielectric properties were listed as $\varepsilon_{\mathrm{r}} \approx$ 8.44, $Q \times f$ value $\approx 64,000 \mathrm{GHz}$, and $\tau_{\mathrm{f}} \approx-37 \mathrm{ppm} /{ }^{\circ} \mathrm{C}$ and $\varepsilon_{\mathrm{r}} \approx 7.94, Q \times f$ value $\approx 38,800 \mathrm{GHz}$, and $\tau_{\mathrm{f}} \approx$ $-53 \mathrm{ppm} /{ }^{\circ} \mathrm{C}$ with the molar ratio of $\mathrm{Re}_{2} \mathrm{O}_{3} / \mathrm{SiO}_{2}=$ $1: 1.05$, respectively [31,32].

\subsubsection{Ternary silicate and germanate ceramics}

Clinopyroxene-type $\mathrm{ABC}_{2} \mathrm{O}_{6}(\mathrm{~A}=\mathrm{Ca} ; \mathrm{B}=\mathrm{Co}, \mathrm{Mg}, \mathrm{Zn}$, $\mathrm{Fe} ; \mathrm{C}=\mathrm{Si}, \mathrm{Ge}$ ) materials, akermanite-type $\mathrm{A}_{2} \mathrm{BC}_{2} \mathrm{O}_{7}$ $(\mathrm{A}=\mathrm{Sr}, \mathrm{Ca} ; \mathrm{B}=\mathrm{Mg}, \mathrm{Zn}, \mathrm{Co}, \mathrm{Mn} ; \mathrm{C}=\mathrm{Si}, \mathrm{Ge})$, and melilite-type $\mathrm{A}_{2} \mathrm{BSi}_{2} \mathrm{O}_{7}(\mathrm{~A}=\mathrm{Sr}, \mathrm{Ca}, \mathrm{Ba} ; \mathrm{B}=\mathrm{Mg}, \mathrm{Zn}$, $\mathrm{Co}, \mathrm{Mn}, \mathrm{Cu}$ ) occupied the primary family of ternary silicate ceramics. Increasing attention has been paid for $\mathrm{CaMgSi}_{2} \mathrm{O}_{6}$ owing to its low permittivity $\approx 7.5$, which is suitable to be substrate [14,33-35]. Both the substitution of $\mathrm{Zn}^{2+}, \mathrm{Co}^{2+}, \mathrm{Cu}^{2+}, \mathrm{Mn}^{2+}$ for $\mathrm{Mg}^{2+}$ and introduction of $\mathrm{Sr}^{2+}$ into $\mathrm{Ca}^{2+}$ of $\mathrm{CaMgSi}_{2} \mathrm{O}_{6}$ were benefit for reducing the dielectric loss. Microstructure with many pores of $\mathrm{CaMnSi}_{2} \mathrm{O}_{6}$ was observed by Chen et al. [36], and the effect of porosity on the properties was investigated by spherical-pore model. Akermanite-type $\mathrm{A}_{2} \mathrm{BC}_{2} \mathrm{O}_{7}(\mathrm{~A}=\mathrm{Sr}, \mathrm{Ca} ; \mathrm{B}=\mathrm{Mg}, \mathrm{Zn}, \mathrm{Co}, \mathrm{Mn} ; \mathrm{C}=\mathrm{Si}, \mathrm{Ge})$ systems belong to the structure group of $P 4 \overline{2} 1 \mathrm{~m}$ (113) in tetragonal, while melilite-type $\mathrm{A}_{2} \mathrm{BC}_{2} \mathrm{O}_{7}(\mathrm{~A}=\mathrm{Ba}$; $\mathrm{B}=\mathrm{Co}, \mathrm{Zn}, \mathrm{Cu}, \mathrm{Mg} ; \mathrm{C}=\mathrm{Si}, \mathrm{Ge})$ and $\mathrm{AB}_{2} \mathrm{C}_{2} \mathrm{O}_{7}(\mathrm{~A}=$ $\mathrm{Ba} ; \mathrm{B}=\mathrm{Co}, \mathrm{Zn} ; \mathrm{C}=\mathrm{Si}, \mathrm{Ge}$ ) systems were clarified in monoclinic structure [37-44]. The literature about the effect of structure evolution and chemical bond parameters in $\mathrm{A}_{2} \mathrm{BSi}_{2} \mathrm{O}_{7}$ and $\mathrm{AB}_{2} \mathrm{Si}_{2} \mathrm{O}_{7}$ represented that 
the $\mathrm{Si}-\mathrm{O}$ bond played the significant role in structural stability and dielectric polarization.

The monoclinic $\mathrm{Ca}_{3} \mathrm{SnSi}_{2} \mathrm{O}_{9}$ and $\mathrm{Ca}_{3} \mathrm{MgSi}_{2} \mathrm{O}_{8}$ with space group $P 2_{1} / c$ were investigated to supplement the compound of ternary silicate oxides. $\mathrm{Ca}_{3} \mathrm{SnSi}_{2} \mathrm{O}_{9}$ ceramics were obtained in a wide sintering temperature region from 1400 to $1525{ }^{\circ} \mathrm{C}$, with non-stoichiometric composition (molar ratio of $\mathrm{Ca}: \mathrm{Sn}: \mathrm{Si}=1: 1.2: 1$ ) as raw materials [45]. Single phase $\mathrm{Ca}_{3} \mathrm{MgSi}_{2} \mathrm{O}_{8}$ possessed near $99 \%$ of the theoretical density after sintered at $1375{ }^{\circ} \mathrm{C}$, with $\varepsilon_{\mathrm{r}} \approx 13.8, Q \times f$ value $\approx 27,000 \mathrm{GHz}$, and $\tau_{\mathrm{f}} \approx-62$ $\mathrm{ppm} /{ }^{\circ} \mathrm{C}$ [46]. Sintering behavior and phase composition of gillespite-structured $\mathrm{MCuSi}_{4} \mathrm{O}_{10}(\mathrm{M}=$ $\left.\mathrm{Ba}_{1-x} \mathrm{Sr}_{x}, \mathrm{Sr}_{1-x} \mathrm{Ca}_{x}\right)$ ceramics were established by Song et al. [47], and $\mathrm{SrCuSi}_{4} \mathrm{O}_{10}$ possessed microwave dielectric properties of $\varepsilon_{\mathrm{r}} \approx 5.59, Q \times f$ value $\approx 82,252 \mathrm{GHz}$, and $\tau_{\mathrm{f}} \approx-41.34 \mathrm{ppm} /{ }^{\circ} \mathrm{C}$. The first-principles calculation was applied to determine where $\mathrm{Ni}^{2+}$ and $\mathrm{Li}^{+}$would occupy in $\mathrm{BaAl}_{2} \mathrm{Si}_{2} \mathrm{O}_{8}$ ceramics, and the change of bond strength and bond valence were analyzed [48,49].

The unpresented ternary silicate and germanate phase in pseudo phase diagrams are summarized as well in this section. The rare earth-based ternary silicate oxides, such as apatite with general formula $\mathrm{A}_{10}\left(\mathrm{MO}_{4}\right)_{6} \mathrm{O}_{2}(\mathrm{~A}=$ alkaline earth, rare earth, $\mathrm{Pb} ; \mathrm{M}=$ $\mathrm{Si}, \mathrm{Ge}, \mathrm{P}, \mathrm{V})$, have received much attention since the apatite structure allowed numbers of substitutions at all the three sites. The lattice parameters and the local charge compensation of apatite type compounds were determined in 1972 [50], and those ceramics were established as candidate of fluorescent lamp phosphors and laser technology. To improve the densification of lithium apatite $\mathrm{LiRe}_{9}\left(\mathrm{SiO}_{4}\right)_{6} \mathrm{O}_{2}$ ceramics $(\mathrm{Re}=\mathrm{La}, \mathrm{Pr}$, $\mathrm{Nd}, \mathrm{Sm}, \mathrm{Eu}, \mathrm{Gd}, \mathrm{Er})$, relative density was higher than $90 \%$ for all samples after doping $1 \mathrm{wt} \% \mathrm{LiF}$ [51]. The microwave dielectric properties of $\mathrm{SrRE}_{4} \mathrm{Si}_{3} \mathrm{O}_{13}(\mathrm{RE}=$ La, Pr, Nd, Sm, Eu, Gd, Tb, Dy, Er, Tm, Yb, and Y) were in the range of 9-16 for permittivity with the maximum of $Q \times f$ value $\approx 26,000 \mathrm{GHz}$ [52], while the optimal microwave dielectric properties of $\mathrm{CaRE}_{4} \mathrm{Si}_{3} \mathrm{O}_{13}$ $(\mathrm{RE}=\mathrm{La}, \mathrm{Nd}, \mathrm{Sm}$, and $\mathrm{Er})$ were $\varepsilon_{\mathrm{r}} \approx 13.37, Q \times f$ value $\approx$ $18,600 \mathrm{GHz}$, and $\tau_{\mathrm{f}} \approx-17.8 \mathrm{ppm} /{ }^{\circ} \mathrm{C}$ at $\operatorname{Re}=\operatorname{Er}[53]$.

To obtain new dielectric materials, some researchers pursued materials with the composition containing $\mathrm{GeO}_{2}$ and $\mathrm{Ga}_{2} \mathrm{O}_{3}$ and reported microwave dielectric properties of those materials firstly. With inverse spinel structure, $\mathrm{LiGa}_{5} \mathrm{O}_{8}$ was verified as a cubic structure where $\mathrm{Li}^{+}$and $\mathrm{Ga}^{3+}$ distributed in the octahedral $\mathrm{B}$ site with 1:3 ordering [54]. The large deviation between $\varepsilon_{\mathrm{r}}$ and $\varepsilon_{\text {rth }}$ in $\mathrm{Ba}_{2} \mathrm{MGa}_{11} \mathrm{O}_{20}(\mathrm{M}=\mathrm{Bi}$, La) was ascribed to the "rattling" effect of cations and the existence of lone pair ions of $\mathrm{Bi}^{3+}$ [55]. The different $\tau_{\mathrm{f}}$ values of $\mathrm{AGe}_{4} \mathrm{O}_{9}(\mathrm{~A}=\mathrm{Ba}, \mathrm{Sr})$ were ascribed to the distortion of $\left[\mathrm{GeO}_{6}\right]$ octahedron where $\tau_{\mathrm{f}}$ values were $-44.2 \mathrm{ppm} /{ }^{\circ} \mathrm{C}$ for the former and $-11.7 \mathrm{ppm} /{ }^{\circ} \mathrm{C}$ for the later [56]. Normal garnet $\mathrm{A}_{3} \mathrm{Y}_{2} \mathrm{Ge}_{3} \mathrm{O}_{12}(\mathrm{~A}=\mathrm{Ca}, \mathrm{Mg})$ ceramics possessed $\tau_{\mathrm{f}} \approx 120.5 \mathrm{ppm} /{ }^{\circ} \mathrm{C}$ for $\mathrm{A}=\mathrm{Ca}$ and $-40.6 \mathrm{ppm} /{ }^{\circ} \mathrm{C}$ for $\mathrm{A}=\mathrm{Mg}$ [57]. As doped ions, $\left(\mathrm{Li}_{0.5} \mathrm{Ga}_{0.5}\right)^{3+}$ in $\mathrm{Mg}_{2} \mathrm{Al}_{4} \mathrm{Si}_{5} \mathrm{O}_{18}$ would obtain the highest $Q \times f$ value of 50,560 GHz [58]. $\mathrm{Ca}_{3} \mathrm{M}_{2} \mathrm{Si}_{3} \mathrm{O}_{12}(\mathrm{M}=\mathrm{Yb}, \mathrm{Y})$ ceramics were consistent with the general formula of garnet structure, and those ceramics crystalized as silico-carnotite structure with high-energy ball milling method [59]. The microwave dielectric properties were recorded as $\varepsilon_{\mathrm{r}} \approx 9.2, Q \times f$ value $\approx 56,400 \mathrm{GHz}$, and $\tau_{\mathrm{f}} \approx$ $-77.5 \mathrm{ppm} /{ }^{\circ} \mathrm{C}$ and $\varepsilon_{\mathrm{r}} \approx 8.7, Q \times f$ value $\approx 29,094 \mathrm{GHz}$, and $\tau_{\mathrm{f}} \approx-76.8 \mathrm{ppm} /{ }^{\circ} \mathrm{C}$ for $\mathrm{Ca}_{3} \mathrm{Yb}_{2} \mathrm{Si}_{3} \mathrm{O}_{12}$ and $\mathrm{Ca}_{3} \mathrm{Y}_{2} \mathrm{Si}_{3} \mathrm{O}_{12}$, respectively. A serial of $\mathrm{Ca}_{3} \mathrm{MZrGe}_{3} \mathrm{O}_{12}$ $(\mathrm{M}=\mathrm{Co}, \mathrm{Zn}), \mathrm{Ca}_{4} \mathrm{ZrGe}_{3} \mathrm{O}_{12}$, and $\mathrm{Ca}_{3} \mathrm{~B}_{2} \mathrm{Ge}_{3} \mathrm{O}_{12}(\mathrm{~B}=\mathrm{Al}$, $\mathrm{Ga}$ ) ceramics were successfully prepared, and the quality factors were higher than that of $\mathrm{Ca}_{3} \mathrm{M}_{2} \mathrm{Si}_{3} \mathrm{O}_{12}$ [60-62]. Similarly, $\mathrm{Sr}_{3} \mathrm{~B}_{2} \mathrm{Ge}_{3} \mathrm{O}_{12}(\mathrm{~B}=\mathrm{Yb}, \mathrm{Ho})$ were investigated by $\mathrm{Li}$ et al. [63] using vibration spectroscopy, and the $\tau_{\mathrm{f}}$ was tuned to near zero with $\mathrm{CaTiO}_{3}$ ceramics. $0.8 \mathrm{Y}_{3} \mathrm{MgAl}_{3} \mathrm{SiO}_{12}-0.2 \mathrm{TiO}_{2}$ ceramic sintered at $1475{ }^{\circ} \mathrm{C}$ showed a $\tau_{\mathrm{f}} \approx+5.2 \mathrm{ppm} /{ }^{\circ} \mathrm{C}$, where the co-existed phase contained $\mathrm{Y}_{2} \mathrm{Ti}_{2} \mathrm{O}_{7}$ and $\mathrm{TiO}_{2}$ along with $\mathrm{Y}_{3} \mathrm{MgAl}_{3} \mathrm{SiO}_{12}$ phase [64]. Dense $\mathrm{Mg}_{3} \mathrm{Ga}_{2} \mathrm{GeO}_{8}$ ceramics presented microwave dielectric properties of $\varepsilon_{\mathrm{r}} \approx 9.41, Q \times f$ value $\approx 133,113 \mathrm{GHz}$, and $\tau_{\mathrm{f}} \approx-63.54$ $\mathrm{ppm} /{ }^{\circ} \mathrm{C}$ [65]. Single phase $\mathrm{LiYSiO}_{4}$ ceramics could be obtained in $1100-1140{ }^{\circ} \mathrm{C}$, and a near-zero $\tau_{\mathrm{f}}$ of $(+4.52)-(+8.03) \mathrm{ppm} /{ }^{\circ} \mathrm{C}$ was observed [66].

Furthermore, phase transition from $A 2 / a$ to $P 2_{1} / a$ was observed in new silicate in the formula of $\mathrm{CaSn}_{1-x} \mathrm{Ti}_{x} \mathrm{SiO}_{5}$, where the variation of $\tau_{\mathrm{f}}$ values was ascribed to the $\mathrm{Sn} / \mathrm{TiO}_{6}$ octahedral distortion [67]. Secondary phase of $\mathrm{SnO}_{2}$ and $\mathrm{SrSiO}_{3}$ appeared at $0.2 \leqslant x \leqslant 0.45$ in $\mathrm{Ca}_{1-x} \mathrm{Sr}_{x} \mathrm{SnSiO}_{5}$ ceramics, which could adjust the positive $\tau_{\mathrm{f}}$ of $\mathrm{CaSnSiO}_{5}$ to $-1.2 \mathrm{ppm} /{ }^{\circ} \mathrm{C}$ [68]. $\mathrm{CaSiO}_{3}$ and $\mathrm{CaSnSiO}_{5}$ phases would improve the $\tau_{\mathrm{f}}$ to $-7.2 \mathrm{ppm} /{ }^{\circ} \mathrm{C}$ in $\mathrm{Ca}_{2}\left(\mathrm{Hf}_{1-x} \mathrm{Sn}_{x}\right) \mathrm{Si}_{4} \mathrm{O}_{12}$ when $x=0.4$ [69].

\section{2 Niobate and tantalate based on $\mathrm{ZnO}-\mathrm{Nb}_{2} \mathrm{O}_{5}-\mathrm{TiO}_{2}$}

There is a large body of niobate and tantalate dielectric ceramics, and the relevant researches highlight the phase evolution, structure transformation, and chemical 
bond characteristics. In order to elucidate the influence of undercoordinated sites on the dielectric properties, analysis according to $\mathrm{P}-\mathrm{V}-\mathrm{L}$ theory and vibration spectra is verified as valid approach to understand the relationship of the state of chemical bond with polarization and stability of lattice. Indeed, it seems that researchers could identify the contribution of each chemical bond to dielectric properties by $\mathrm{P}-\mathrm{V}-\mathrm{L}$ theory and infrared reflectivity spectrum. However, reaching general conclusions about the effect of a unique chemical bond or Wycoff site on different properties may be difficult, since the $\mathrm{P}-\mathrm{V}-\mathrm{L}$ theory is just predictable theoretically. The actual dielectric properties of ceramics are still evaluated based on experiments, and thorough, quantitative, and multiperspective analysis is required. Figure 4 is the phase diagram of the mainly reported niobate and tantalate dielectric ceramics, where the rutile-type, ixiolitetype, and columbite-type structures were obtained after $\left(\mathrm{Zn}_{1 / 3} \mathrm{Nb}_{2 / 3}\right)^{4+}$ was doped into $\mathrm{TiO}_{2}$. The detailed phase division of $\mathrm{A}_{0.5} \mathrm{~B}_{0.5} \mathrm{CO}_{4}$ and the relevant investigations of this binary system are summarized in the following.

\subsubsection{Rutile-trirutile/ixiolite/wolframite-columbite type ceramics}

Rutile, brookite, and anatase are the three types of $\mathrm{TiO}_{2}$ in nature. $\mathrm{TiO}_{2}$ itself possesses a high permittivity $\approx$ 100 , a low dielectric loss tangent $(\tan \sigma)$ value $\left(6 \times 10^{-5}\right.$ at a frequency of $3 \mathrm{GHz}$ ), and a high $\tau_{\mathrm{f}}$ value of $450 \mathrm{ppm} /{ }^{\circ} \mathrm{C}$ [70]. It is valid that $\mathrm{TiO}_{2}$ phase is used to target the aim of near zero $\tau_{\mathrm{f}}$ value as a secondary phase in the system with a negative $\tau_{\mathrm{f}}$ value. Meanwhile, long-term focus has been paid on the structure transformation and property optimization of $\mathrm{TiO}_{2}$ with

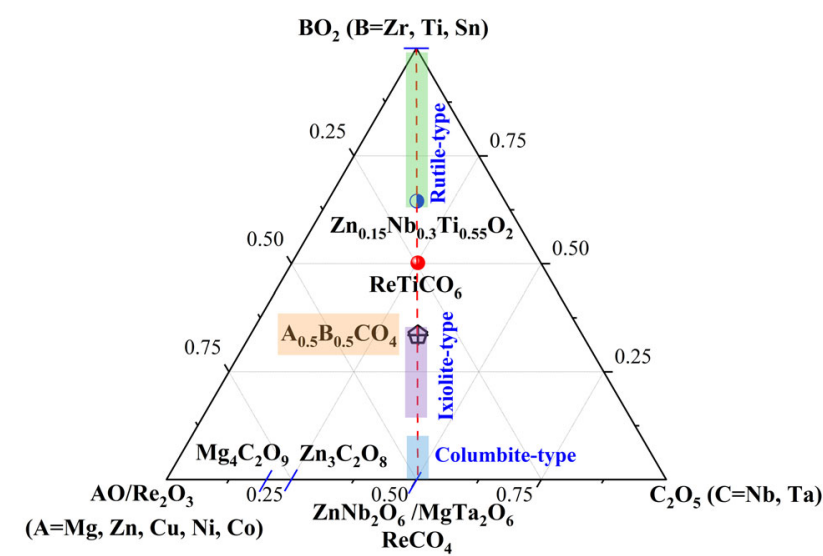

Fig. 4 Pseudo phase diagram of the niobate and tantalite. substitution ions of different physicochemical properties. The cation substitution for $\mathrm{Ti}^{4+}$ can reduce the dielectric loss or tune the $\tau_{\mathrm{f}}$ value, evolving monovalent, divalent, trivalent, tetravalent, or pentavalent cations, and their groups of two cations. Especially, the extensive elaboration of dependence of microwave dielectric properties on the crystal structure of $\left(\mathrm{Zn}_{1 / 3} \mathrm{~B}_{2 / 3}^{5+}\right)_{x} \mathrm{Ti}_{1-x} \mathrm{O}_{2}$ $\left(\mathrm{B}^{5+}=\mathrm{Nb}\right.$, Ta $)$ ceramics was reported by Kim and Kang [71]. The phase relation of ternary system of $\mathrm{ZnO}-\mathrm{TiO}_{2}-\mathrm{Nb}_{2} \mathrm{O}_{5}$ was first discussed in 1992 [72]. It summarized that the solid solution of rutile phase appeared in the range of molar content of $\left(\mathrm{Zn}_{1 / 3} \mathrm{Nb}_{2 / 3}\right)^{4+}$ lower than $58 \%$, ixiolite $\mathrm{ZnTiNb}_{2} \mathrm{O}_{8}$ exited in the range of $69 \%-85 \%$, while columbite solid solution of $\mathrm{ZnNb}_{2} \mathrm{O}_{6}$ formed when the content was higher than 93\% [73], and the solid solution area of different types was marked with shadow in the pseudo phase diagram in Fig. 4.

Compared with the ongoing report of $\mathrm{ZnTiNb}_{2} \mathrm{O}_{8}$, the study of $\mathrm{Zn}_{0.15} \mathrm{Nb}_{0.3} \mathrm{Ti}_{0.55} \mathrm{O}_{2}$ is still rare. Generally, $\mathrm{Zn}_{0.15} \mathrm{Nb}_{0.3} \mathrm{Ti}_{0.55} \mathrm{O}_{2}$ appeared as the secondary phase which would control the dielectric properties of composite ceramics [74-76]. It possessed properties of $\varepsilon_{\mathrm{r}} \approx 94.35, Q \times f$ value $\approx 10,889 \mathrm{GHz}$, and $\tau_{\mathrm{f}} \approx 353.43$ $\mathrm{ppm} /{ }^{\circ} \mathrm{C}$, sintered at $1050{ }^{\circ} \mathrm{C}$ [71], which was potential to be $\tau_{\mathrm{f}}$ compensator as $\mathrm{TiO}_{2}$. Yang et al. [77] directly added the $\mathrm{Zn}_{0.15} \mathrm{Nb}_{0.3} \mathrm{Ti}_{0.55} \mathrm{O}_{2}$ into $\mathrm{Zn}_{0.5} \mathrm{Ti}_{0.5} \mathrm{NbO}_{4}$ ceramics, and the structure evolution and chemical bond parameters have been calculated. $\mathrm{Zr}^{4+}$ with the larger radius than $\mathrm{Ti}^{4+}$ was used to dope into $\mathrm{Zn}_{0.15} \mathrm{Nb}_{0.3}\left(\mathrm{Ti}_{1-x} \mathrm{Zr}_{x}\right)_{0.55} \mathrm{O}_{2}$ [78], where the expansion of bond length and cell volume renders the decline of covalency of all bonds. The decline of bond ionicity was obtained since the shrinking of cell volume and bond length in $\mathrm{Zn}_{0.15} \mathrm{Nb}_{0.3-x} \mathrm{Ta}_{x} \mathrm{TiZr}_{0.55} \mathrm{O}_{2}$ [79].

The structure of formula $\mathrm{A}_{0.5} \mathrm{~B}_{0.5} \mathrm{CO}_{4}$ can be categorized into four types: wolframite-type $\mathrm{AZrB}_{2} \mathrm{O}_{8}$ $(\mathrm{A}=\mathrm{Mn}, \mathrm{Zn}, \mathrm{Mg}, \mathrm{Co}, \mathrm{Ni} ; \mathrm{B}=\mathrm{Nb}, \mathrm{Ta})$, rutile-type $\mathrm{A}_{0.5} \mathrm{Ti}_{0.5} \mathrm{NbO}_{4}(\mathrm{~A}=\mathrm{Ni}, \mathrm{Co}, \mathrm{Cu})$, tetragonal trirutiletype $\mathrm{A}_{0.5} \mathrm{Ti} / \mathrm{Sn}_{0.5} \mathrm{TaO}_{4}$ structure $(\mathrm{A}=\mathrm{Co}, \mathrm{Ni}, \mathrm{Zn}, \mathrm{Mg})$, and ixiolite-type $\mathrm{ZnTiNb}_{2} \mathrm{O}_{8}$. The schematic of those classifications is shown in Fig. 5, and the related investigations of each structure are illustrated in this section. The effects of different cations ( $\mathrm{Mn}, \mathrm{Zn}, \mathrm{Mg}$, $\mathrm{Ni}$, and $\mathrm{Co}$ ) at A-site of $\mathrm{AZrNb}_{2} \mathrm{O}_{8}$ illustrated that dielectric constant, quality factor, and $\tau_{\mathrm{f}}$ values relied on the ionic polarizability, packing fraction, and B-site octahedral distortions, respectively [80-85]. Among them, $\mathrm{MgZrNb}_{2} \mathrm{O}_{8}$ shows the optimal quality factor 
$\left(\varepsilon_{\mathrm{r}} \approx 26, Q \times f\right.$ value $\approx 120,816 \mathrm{GHz}$, and $\tau_{\mathrm{f}} \approx-50.2 \mathrm{ppm} /{ }^{\circ} \mathrm{C}$, at $f=6.85 \mathrm{GHz}$ [86]). The microwave dielectric properties of wolframite-type $\mathrm{AZrB}_{2} \mathrm{O}_{8}(\mathrm{~A}=\mathrm{Mn}, \mathrm{Zn}$, $\mathrm{Mg}, \mathrm{Co}, \mathrm{Ni} ; \mathrm{B}=\mathrm{Nb}, \mathrm{Ta}$ ) and the structure-relationship were determined via combining the far-infrared and terahertz spectroscopy with $\mathrm{P}-\mathrm{V}-\mathrm{L}$ theory [87-91]. Partial replace of A-site (such as $\mathrm{Mg}_{0.5} \mathrm{Zn}_{0.5} \mathrm{ZrNb}_{2} \mathrm{O}_{8}$ [92], $\mathrm{Zn}_{1-x} \mathrm{Co}_{x} \mathrm{ZrNb}_{2} \mathrm{O}_{8}$ [93-95]), Zr-site substitution of $\mathrm{Zn}\left(\mathrm{Ti}_{1-x} \mathrm{Zr}_{x}\right) \mathrm{Ta}_{2} \mathrm{O}_{8}$ [96], $\mathrm{ZnZr}_{1-x} \mathrm{Sn}_{x} \mathrm{Nb}_{2} \mathrm{O}_{8}$ [97,98], doped $\mathrm{Nb}$-site of $\mathrm{MgZr}\left(\mathrm{Nb}_{1-x} \mathrm{Sb}_{x}\right)_{2} \mathrm{O}_{8}$ [99,100], $\mathrm{ZnZrNbTaO}_{8}$ [101], $\mathrm{MgZrNb}_{2-x}\left(\mathrm{Sn}_{1 / 2} \mathrm{~W}_{1 / 2}\right)_{x} \mathrm{O}_{8}$ [102], and nonstoichiometric $\mathrm{MgZrNb}_{2+x} \mathrm{O}_{8+2.5 x}$ [103] provided evidence that relative density, packing fraction, bond valence, and chemical bond characteristics majored the variation of microwave dielectric properties. To adjust the negative $\tau_{\mathrm{f}}$ values, the study about the relationship of $\mathrm{TiO}_{2}$ on $\mathrm{MgZrNb}_{2} \mathrm{O}_{8}$ [104] and $\mathrm{ZnZrNb}_{2} \mathrm{O}_{8}$ [105] presented that co-exited ceramics would reach near zero $\tau_{\mathrm{f}}$ values. The microwave dielectric properties were $\varepsilon_{\mathrm{r}} \approx 43, Q \times f$ value $\approx 46,110 \mathrm{GHz}$, and $\tau_{\mathrm{f}} \approx-2.5$ $\mathrm{ppm} /{ }^{\circ} \mathrm{C}$ for $0.63 \mathrm{MgZrNb}_{2} \mathrm{O}_{8}-0.37 \mathrm{TiO}_{2}$ ceramics; $\varepsilon_{\mathrm{r}} \approx$ $44, Q \times f$ value $\approx 38,500 \mathrm{GHz}$, and $\tau_{\mathrm{f}} \approx-2.4 \mathrm{ppm} /{ }^{\circ} \mathrm{C}$ for $0.3 \mathrm{ZnZrNb}_{2} \mathrm{O}_{8}-0.7 \mathrm{TiO}_{2}$ ceramics. Additionally, literature demonstrated that $\mathrm{H}_{3} \mathrm{BO}_{3}$ or $\mathrm{B}_{2} \mathrm{O}_{3}$ addictive aids could contributed to densification and improvement of the sintering behavior for $\mathrm{ZnZrNb}_{2} \mathrm{O}_{8}$ and $\mathrm{MgZrNb}_{2} \mathrm{O}_{8}$ [106-108].

The dielectric properties of $\mathrm{A}_{0.5} \mathrm{~B}_{0.5} \mathrm{NbO}_{4}$ ceramics are much different. $\mathrm{Ni}_{0.5} \mathrm{Ti}_{0.5} \mathrm{NbO}_{4}$ and $\mathrm{Cu}_{0.5} \mathrm{Ti}_{0.5} \mathrm{NbO}_{4}$ crystalized in rutile structure presented with positive $\tau_{\mathrm{f}}$ values of 79.1 and $49.2 \mathrm{ppm} /{ }^{\circ} \mathrm{C}$, respectively $[109,110]$. The characteristic of rutile $\mathrm{Co}_{0.5} \mathrm{Ti}_{0.5} \mathrm{NbO}_{4}$ was sought by solid state reaction and sol-gel method [111,112], where the microwave dielectric properties were $\varepsilon_{\mathrm{r}} \approx 64$, $Q \times f$ value $\approx 65,300 \mathrm{GHz}, \tau_{\mathrm{f}} \approx 223.2 \mathrm{ppm} /{ }^{\circ} \mathrm{C}$ and $\varepsilon_{\mathrm{r}} \approx$
64.19, $Q \times f$ value $\approx 16,800 \mathrm{GHz}, \tau_{\mathrm{f}} \approx 66.17 \mathrm{ppm} /{ }^{\circ} \mathrm{C}$, respectively. In the solid solution of $\mathrm{Ni}_{0.5-x} \mathrm{Zn}_{x} \mathrm{Ti}_{0.5} \mathrm{NbO}_{4}$, the dielectric constant was enhanced from 56.8 to 62.54 [113]. Introduction of $\mathrm{CoNb}_{2} \mathrm{O}_{6}$ and $\mathrm{Zn}_{1.01} \mathrm{Nb}_{2} \mathrm{O}_{6}$ into $\mathrm{CoTiNb}_{2} \mathrm{O}_{8}$ rendered the $Q \times f$ increasing considerably due to the enhanced densification and obtained the $\tau_{\mathrm{f}}$ values of 0.5 and $0 \mathrm{ppm} /{ }^{\circ} \mathrm{C}$, respectively $[114,115]$. Zhang et al. [116] and Li et al. [117] reported that $\tau_{\mathrm{f}}$ value would shift from positive to negative after $\mathrm{Zr}$ substitution in $\mathrm{CoTi}_{1-\chi} \mathrm{Zr}_{x} \mathrm{Nb}_{2} \mathrm{O}_{8}$, where the $\tau_{\mathrm{f}}$ value was correlated with oxygen octahedral distortion and B-site bond valence. Superlattice diffraction peak which is relevant with cation ordering was observed in $\mathrm{Co}_{0.5} \mathrm{Ti}_{0.5} \mathrm{Nb}_{1-x} \mathrm{Sb}_{x} \mathrm{O}_{4}$ ceramics, contributing to the augment of $Q \times f$ value [118].

The trirutile-type structure was observed in some tantalates, antimonates, and bismuthates. This crystal structure was built by ordering octahedral cations along $c$-axis, which possessed three times $c$-axis of rutile-type one $[119,120]$. Currently, $\mathrm{Co}_{0.5} \mathrm{Ti}_{0.5} \mathrm{TaO}_{4}$ [121], $\mathrm{NiTiTa}_{2} \mathrm{O}_{8}$ [122], $\mathrm{Co}_{0.5} \mathrm{Zr}_{0.5} \mathrm{TaO}_{4}$ [90], $\mathrm{NiSnTa}_{2} \mathrm{O}_{8}$ [123] were reported as trirutile-type structure. Among them, $\mathrm{NiSnTa}_{2} \mathrm{O}_{8}$ showed a near zero $\tau_{\mathrm{f}}$ value $\left(\varepsilon_{\mathrm{r}} \approx 21.04\right.$, $Q \times f$ value $\approx 31,328 \mathrm{GHz}$, and $\tau_{\mathrm{f}} \approx-2.63 \mathrm{ppm} /{ }^{\circ} \mathrm{C}$ ).

Ixiolite phase $\mathrm{ZnTiNb}_{2} \mathrm{O}_{8}$ is a fully disordered $\alpha-\mathrm{PbO}_{2}$ structure, where $\mathrm{Zn} / \mathrm{Ti} / \mathrm{Nb}$ ions statistically occupied the octahedral cation sites [124]. Up to now, numbers of substitution on $\mathrm{ZnTiNb}_{2} \mathrm{O}_{8}$ have been reported, such as $\mathrm{Co}$ [125], $\mathrm{Mg}$ [74], $\mathrm{Ca}$ [126], $\mathrm{Sn}$ [127], $\mathrm{Zr}$ [128], and Ta [129-131]. The crystal structure refinement and Raman spectrum study of $\mathrm{ZnTiNb}_{2} \mathrm{O}_{8}$, together with the mode assignment were completed by Liao and $\mathrm{Li}$ [132]. In the $\mathrm{ZnO}-\mathrm{Nb}_{2} \mathrm{O}_{5}-x \mathrm{TiO}_{2}(1 \leqslant x \leqslant 2)$ system, ceramics were composed of $\mathrm{Zn}_{0.17} \mathrm{Nb}_{0.33} \mathrm{Ti}_{0.5} \mathrm{O}_{2}$ and $\mathrm{ZnTiNb}_{2} \mathrm{O}_{8}$ when $x \geqslant 1.8$ [133]. Using the effective

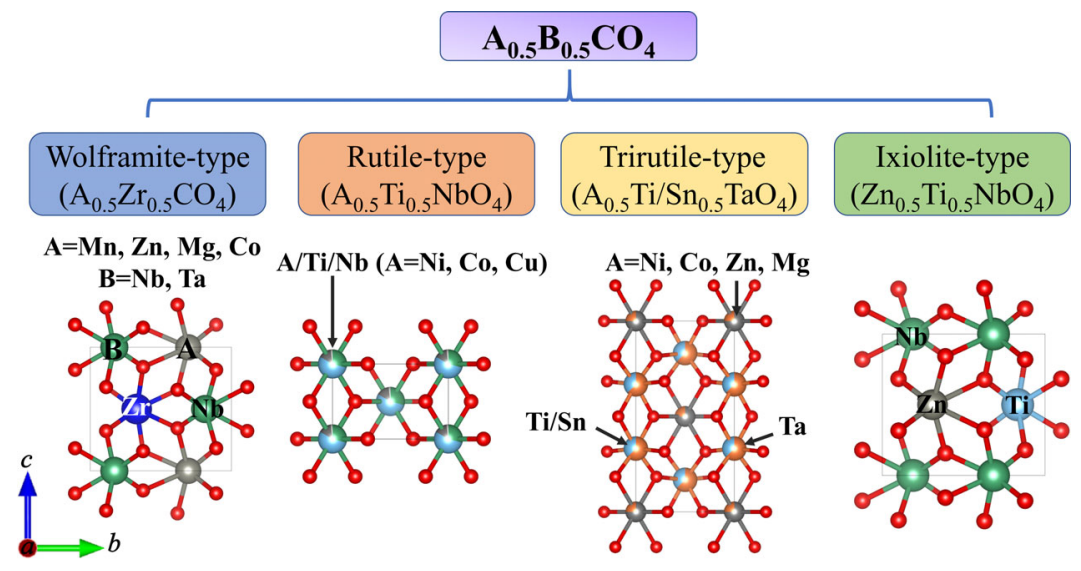

Fig. 5 Schematic of classification of $\mathrm{A}_{0.5} \mathrm{~B}_{0.5} \mathrm{CO}_{4}$. 
route of sintering reaction for $\mathrm{ZnNb}_{2} \mathrm{O}_{6}$ and $\mathrm{TiO}_{2}$ nano powders, a superior property of $\mathrm{ZnTiNb}_{2} \mathrm{O}_{8}$ was achieved compared with that prepared by solid-state method [134]. Dielectric constant and dielectric loss were evaluated in microwave and $\mathrm{THz}$ range in $\mathrm{Al}_{0.5} \mathrm{Nb}_{0.5}$ doped into $\mathrm{ZnTiNb}_{2} \mathrm{O}_{8}$, where the results indicated the negligible shift of dielectric constant in those frequencies, as shown in Fig. 6 [135]. Furthermore, ixiolite $\mathrm{MgTiNb}_{2} \mathrm{O}_{8}$ prepared by aqueous sol-gel process and then sintered at $1000{ }^{\circ} \mathrm{C}$ showed $\varepsilon_{\mathrm{r}} \approx 33.8$, $Q \times f$ value $\approx 26,260 \mathrm{GHz}$, and $\tau_{\mathrm{f}} \approx-19.2 \mathrm{ppm} /{ }^{\circ} \mathrm{C}$ [136].

In the family of $\mathrm{AB}_{2} \mathrm{O}_{6}(\mathrm{~A}=\mathrm{Ca}, \mathrm{Mg}, \mathrm{Mn}, \mathrm{Co}, \mathrm{Ni}$, $\mathrm{Zn} ; \mathrm{B}=\mathrm{Ta}, \mathrm{Nb})$, the relationship of permittivity with electronegativity was presented by Lee et al. [137]. Two structure classifications have been identified in this system, namely rutile-type (trirutile) and $\alpha-\mathrm{PbO}_{2}-$ type (tri- $\alpha-\mathrm{PbO}_{2}$, columibite) $[138,139]$. Comprehensive studies of columbite niobates concluded that the $\varepsilon_{\mathrm{r}}$ was in the range of $17-22, \tau_{\mathrm{f}}$ value varied from -45 to -76 ,

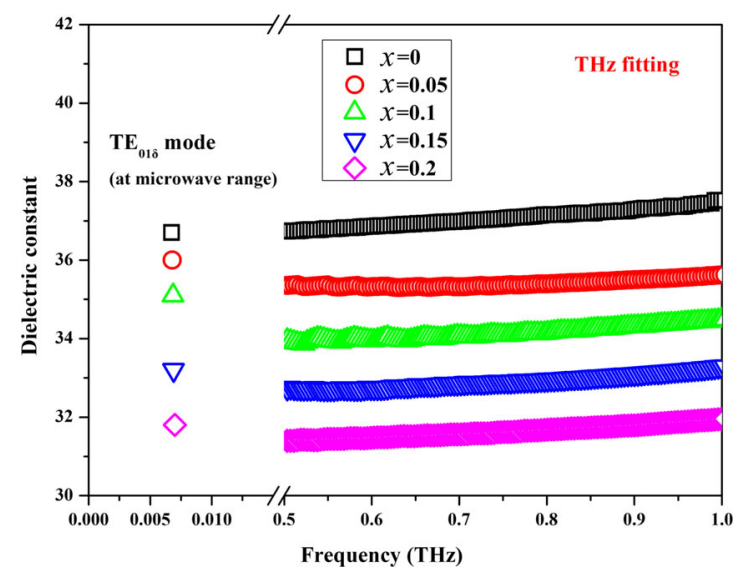

Fig. 6 Absorption coefficients of $\mathrm{ZnTi}_{1-x}\left(\mathrm{Al}_{0.5} \mathrm{Nb}_{0.5}\right)_{x} \mathrm{Nb}_{2} \mathrm{O}_{8}$ ceramics at 0.6 and $0.9 \mathrm{THz}$. Reproduced with permission from Ref. [135], (C) The American Ceramic Society 2019. and the $Q \times f$ value was over $95,000 \mathrm{GHz}$ of $\mathrm{MgNb}_{2} \mathrm{O}_{6}$ $[140,141]$. The investigations about property optimization and preparation methods were concentrated on $\mathrm{MgNb}_{2} \mathrm{O}_{6}, \mathrm{ZnNb}_{2} \mathrm{O}_{6}$, and $\mathrm{ZnTa}_{2} \mathrm{O}_{6}$ due to their potential of application. For sintering behavior, the sintering temperature can be reduced to $1150{ }^{\circ} \mathrm{C}$ of $\mathrm{MgNb}_{2} \mathrm{O}_{6}$ by sol-gel method [142]. Doped ceramics of $\left(\mathrm{Zn}_{1-x} \mathrm{Ni}_{x}\right) \mathrm{Ta}_{2} \mathrm{O}_{6} \quad$ [143], $\quad \mathrm{Zn}\left(\mathrm{Ta}_{1-x} \mathrm{Nb}_{x}\right)_{2} \mathrm{O}_{6} \quad$ [144], $\mathrm{Zn}\left(\mathrm{Ta}_{1-x} \mathrm{Sb}_{x}\right)_{2} \mathrm{O}_{6} \quad$ [145], and composite ceramics composed of $\mathrm{ZnO}-\mathrm{Nb}_{2} \mathrm{O}_{5}-1.75 \mathrm{TiO}_{2}-5 \mathrm{~mol} \% \mathrm{MgO}$, $(1-x) \mathrm{ZnTa}_{2} \mathrm{O}_{6}-x \mathrm{MgNb}_{2} \mathrm{O}_{6}, \quad(1-x) \mathrm{ZrTi}_{2} \mathrm{O}_{6}-x \mathrm{ZnNb}_{2} \mathrm{O}_{6}$, and $(1-x) \mathrm{ZnTa}_{2} \mathrm{O}_{6}-x \mathrm{NiNb}_{2} \mathrm{O}_{6}$ were designed successfully to reach near-zero $\tau_{\mathrm{f}}$ value [146-149]. Liu and Deng [150] proposed that the grain size of $\mathrm{ZnNb}_{2} \mathrm{O}_{6}$ $\left(\mathrm{Zn}_{0.7} \mathrm{Mg}_{0.3}\right) \mathrm{TiO}_{3}$ ceramics became smaller with the $\mathrm{ZnNb}_{2} \mathrm{O}_{6}$ content increasing. The secondary $\mathrm{ZnV}_{2} \mathrm{O}_{6}$ was observed with higher than $1 \mathrm{wt} \% \mathrm{~V}_{2} \mathrm{O}_{5}$ into $\mathrm{ZnNb}_{2} \mathrm{O}_{6}$ [151]. The property comparison of $\mathrm{MgTa}_{2} \mathrm{O}_{6}$ was obtained by sol-gel procession and solid reaction sintering by $\mathrm{Wu}$ et al. [152]. Liu et al. [153] verified that the unpaired d-electrons contribution to the room temperature loss should be taken into consideration of $\mathrm{ZrTiO}_{4}-\mathrm{ZnNb}_{2} \mathrm{O}_{6}$. It was interesting that the structure transformation was identified as tri- $\alpha-\mathrm{PbO}_{2}, \alpha-\mathrm{PbO}_{2}$, trirutile, and rutile in $(1-x) \mathrm{ZnTa}_{2} \mathrm{O}_{6}-x \mathrm{TiO}_{2}$ along with the increase of $x$ [154]. $\mathrm{ZnNb}_{2} \mathrm{O}_{6}$ ceramics prepared by microwave sintering exhibited relative density of $94.3 \%$, and the quality factor was dominated by the distribution of grain size [155]. Recently, the intrinsic dielectric properties were investigated using chemical bond theory and lattice vibrational spectra, which indicated that $\mathrm{B}_{1 \mathrm{u}}$ mode at $168.87 \mathrm{~cm}^{-1}$ was highly related to the dielectric properties [156], and the fitted results of infrared-related spectrum are presented in Fig. 7.
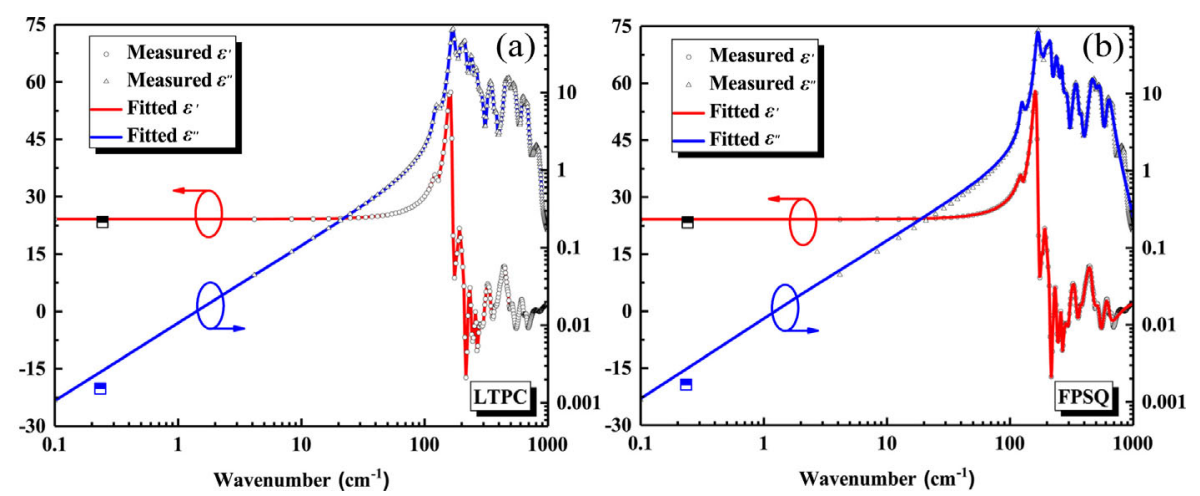

Fig. 7 Real $\varepsilon^{\prime}(\omega)$ and imaginary $\varepsilon^{\prime \prime}(\omega)$ of relative permittivity after (a) LTPC and (b) FPSQ mode fit. LTPC, Lorentz three parameter semiquantum model; FPSQ, four parameter semiquantum model. Reproduced with permission from Ref. [156], (C) The American Ceramic Society 2019. 


\subsection{2 $\mathrm{ReTiCO}_{6}$ ceramics}

The crystal structure of double tantalates of rare-earth elements with titanium tantalite compounds based on $\mathrm{ReTiTaO}_{6}$ is sorted into two parts: orthorhombic aeschynite symmetry with rare earth atomic number in the range of 55-66 and orthorhombic euxenite symmetry with that of 67-71 [157,158]. Generally, high $\varepsilon_{\mathrm{r}}$ and positive $\tau_{\mathrm{f}}$ were obtained for the former, while relatively low $\varepsilon_{\mathrm{r}}$ and negative $\tau_{\mathrm{f}}$ were observed for the latter. The effect of microstructure on properties of $\mathrm{RETiNbO}_{6}(\mathrm{RE}=\mathrm{La}, \mathrm{Sm}$, and Y) ceramics was presented by Lei et al. [159]. The dielectric constant of RETiNbO $_{6}$ system $(\mathrm{RE}=\mathrm{Ce}, \mathrm{Pr}, \mathrm{Nd}, \mathrm{Sm}, \mathrm{Eu}, \mathrm{Gd}, \mathrm{Tb}$, $\mathrm{Dy}, \mathrm{Y}$, and $\mathrm{Yb})$ and $\mathrm{RETiTaO}_{6}(\mathrm{RE}=\mathrm{La}, \mathrm{Ce}, \mathrm{Pr}, \mathrm{Nd}$, $\mathrm{Sm}, \mathrm{Eu}, \mathrm{Gd}, \mathrm{Tb}, \mathrm{Dy}, \mathrm{Ho}, \mathrm{Y}, \mathrm{Er}, \mathrm{Yb}, \mathrm{Al}$, and $\mathrm{In}$ ) increases with the $\mathrm{RE}$ ionic radius $[157,158]$. It was reported that $\mathrm{LaTiNbO}_{6}$ usually stabilized as a monoclinic structure, and Zhang and Zuo [160] proposed that ceramics with coexistence of $\mathrm{O}$ and $\mathrm{M}$ phases could be achieved after prolonging the annealing time. And then, they [161-164] conducted out the substitutions for $\mathrm{La}$ and $\mathrm{Nb}$ sites, in which the structure evolution, octahedral distortion, and vibrational spectrum were elaborated in detail. More recently, dielectric and optical properties of $\mathrm{Ln}_{0.8} \mathrm{Lu}_{0.2} \mathrm{TiNbO}_{6}$ $(\mathrm{Ln}=\mathrm{Ce}, \mathrm{Pr}, \mathrm{Nd}$, and $\mathrm{Sm})$ were presented by John and Solomon [165], where the optimal microwave dielectric properties were shown for $\mathrm{Sm}_{0.8} \mathrm{Lu}_{0.2} \mathrm{TiNbO}_{6}: \varepsilon_{\mathrm{r}} \approx 35$, $Q \times f$ value $\approx 37,390 \mathrm{GHz}$, and $\tau_{\mathrm{f}} \approx 15 \mathrm{ppm} /{ }^{\circ} \mathrm{C}$.

\subsection{3 $\mathrm{ReCO} \mathrm{O}_{4} / \mathrm{Mg}_{4} \mathrm{C}_{2} \mathrm{O}_{9} / \mathrm{Zn}_{3} \mathrm{C}_{2} \mathrm{O}_{8}$ ceramics}

The $\mathrm{ABO}_{4}$ composition material system of $\mathrm{RENbO}_{4}$ ( $\mathrm{RE}=$ lanthanoid atoms, being $\mathrm{La}$ to $\mathrm{Lu}$ as well as $\mathrm{Y}$ ) was firstly investigated in light of their luminescence, damping, and phase transformation characteristics, and their microwave dielectric properties were firstly proposed in 2006 [166]. The satisfied properties of $\mathrm{LaNbO}_{4}, \mathrm{NdNbO}_{4}$, and $\mathrm{SmNbO}_{4}$ attracted much attention recently. For $\mathrm{NdNbO}_{4}$ ceramics, substitution for $\mathrm{Nd}$ site by single cations such as $\mathrm{Sr}, \mathrm{Ca}, \mathrm{Mn}, \mathrm{Co}$, $\mathrm{Mg}, \mathrm{Zn}, \mathrm{Y}, \mathrm{Al}, \mathrm{Bi}, \mathrm{Sm}, \mathrm{La}$ [167-175], and $\mathrm{Nb}$ site by $\mathrm{Ta}, \mathrm{Sb}$ [176-179] were completed to adjust the microwave dielectric properties. In our recent reports, the groups of different isovalent cations of $\left(\mathrm{A}_{x} \mathrm{~B}_{1-x}\right)^{5+}$ $(\mathrm{A}=\mathrm{Mg}, \mathrm{Al}, \mathrm{Si}, \mathrm{Zr} ; \mathrm{B}=\mathrm{W}, \mathrm{Mo})$ have been listed as valid substitution for $\mathrm{Nb}$ site to reduce dielectric loss [180-183]. The analysis of combination of $\mathrm{P}-\mathrm{V}-\mathrm{L}$ theory and vibration spectrum suggested that doping into $\mathrm{Nb}$ site was beneficial to improving quality factor. Meanwhile, $\mathrm{NdNbO}_{4}$ prepared in sol-gel method or composite ceramics composed of $\mathrm{NdNbO}_{4}-\mathrm{CaTiO}_{3}$ [184], $\mathrm{NdNbO}_{4}-\mathrm{CaF}_{2}$ [185], and $\mathrm{NdNbO}_{4}-\mathrm{MgO}$ [186] have also been reported to perfect the properties. Similarly, intrinsic dielectric properties of $\mathrm{EuNbO}_{4}$ were studied by Liu et al. [187]. In the full range of $\mathrm{La}_{2} \mathrm{O}_{3}-\mathrm{Nb}_{2} \mathrm{O}_{5}-\mathrm{V}_{2} \mathrm{O}_{5}$ system, four typical phase regions were verified, including monoclinic fergusonite, tetragonal sheelite, B-site ordered sheelite, and composite of monoclinic $\mathrm{LaVO}_{4}$ and tetragonal sheelite phases [188]. Likewise, $\mathrm{MgO}$ was designed as an addition for $\mathrm{LaNbO}_{4}$ ceramics and the excellent properties were listed as $\varepsilon_{\mathrm{r}} \approx 19.8, Q \times f$ value $\approx 94,440 \mathrm{GHz}$, and $\tau_{\mathrm{f}} \approx$ $6.1 \mathrm{ppm} /{ }^{\circ} \mathrm{C}$ [189]. More recently, structure-property relationship of another $\mathrm{A}^{3+} \mathrm{B}^{5+} \mathrm{O}_{4}$ binary oxide, zircontype $\mathrm{AVO}_{4}(\mathrm{~A}=\mathrm{Eu}, \mathrm{Y})$ ceramics, was discussed by packing fraction and bond valence [190]. Ferroelastic phase transition from monoclinic fergusonite to tetragonal scheelite was observed by in situ Raman spectroscopy and X-ray diffraction of $\mathrm{La}\left(\mathrm{Nb}_{0.9} \mathrm{~V}_{0.1}\right) \mathrm{O}_{4}$, and the schematic of $\varepsilon_{\mathrm{r}}$ typical-ceramics versus temperature was shown by Zhou et al. [191]. NiO/CoO added into $\mathrm{LaNbO}_{4}$ would distinctly optimize the quality factor since the larger and uniform grain was obtained [192]. Although the thermal properties [193-196] and the first-principles calculation of electronic structure and optic properties of $\mathrm{RETaO}_{4}$ $(\mathrm{RE}=\mathrm{Y}, \mathrm{La}, \mathrm{Sm}, \mathrm{Eu}, \mathrm{Dy}, \mathrm{Er})$ [197] have been investigated, the intrinsic dielectric loss has not been summarized in this system. Microwave dielectric properties of $\mathrm{ErNbO}_{4}$ prepared by sol-gel method were reported by Devesa et al. [198], and the grain size varied from 31.27 to $86.65 \mu \mathrm{m}$ and 40.96 to $78.23 \mu \mathrm{m}$ by Rietveld refinement and Sherrer's formula, respectively. $\mathrm{ZrTiO}_{4}$ followed the general formula of $\mathrm{ABO}_{4}$, and the intrinsic dielectric loss of $\mathrm{Zr}_{0.8} \mathrm{Sn}_{0.2} \mathrm{TiO}_{4}$ was investigated by $\mathrm{THz}$ time domain spectroscopy [199].

The structure of corundum-like phase of $\mathrm{Mg}_{4} \mathrm{Nb}_{2} \mathrm{O}_{9}$ was verified by Kumada et al. [200], where the cations were ordered by the stack of two layers of a mixture of $\mathrm{Mg}$ and $\mathrm{Nb}$ and one layer of $\mathrm{Mg}$ along the $c$-axis. $\mathrm{Mg}_{4}\left(\mathrm{Nb}_{2-x} \mathrm{Ta}_{x}\right) \mathrm{O}_{9}$ solid solution was synthesized in the sintering temperature range of $1350-1400{ }^{\circ} \mathrm{C}$ [201], which possesses a comparable quality factor $(Q \times f$ value $\approx 350,000 \mathrm{GHz}$ for $x=2$ ) to that of $\mathrm{Al}_{2} \mathrm{O}_{3}$. To deal with the limitation of high sintering temperature, both $\mathrm{Mg}_{4} \mathrm{Nb}_{2} \mathrm{O}_{9}$ and $\mathrm{Mg}_{4} \mathrm{Ta}_{2} \mathrm{O}_{9}$ were generated by sol-gel method and the variation of property with 
sintering temperature was analyzed [202-204]. An accompanying minor phase of $\mathrm{Mg}_{5} \mathrm{Nb}_{4} \mathrm{O}_{15}$ gradually disappeared as the calcined temperature increased to $850{ }^{\circ} \mathrm{C}$. High frequency dielectric properties of $\mathrm{A}_{5} \mathrm{~B}_{4} \mathrm{O}_{15}$ microwave dielectric were evaluated by Kamba et al. [205] using far-infrared reflection, transmission spectroscopy, and time-resolved $\mathrm{THz}$ transmission spectroscopy. Considering the negative influence of second phase on properties and sintering behavior of $\mathrm{Mg}_{4} \mathrm{Nb}_{2} \mathrm{O}_{9}$, excess $\mathrm{MgO}$ and $\mathrm{Mg}(\mathrm{OH})_{2}$ were used to adjust the composition of $\mathrm{Mg}_{4} \mathrm{Nb}_{2} \mathrm{O}_{9}$ [206,207], which presented that the appearance of $\mathrm{Mg}_{4} \mathrm{Nb}_{2} \mathrm{O}_{9}$ pure phase was more easily with $\mathrm{Mg}(\mathrm{OH})_{2}$ as raw materials. A dramatically improvement of quality factor was achieved by $\mathrm{Ni}$ and $\mathrm{Ta}$ co-doped into this system, and $\left(\mathrm{Mg}_{0.95} \mathrm{Ni}_{0.05}\right)_{4}\left(\mathrm{Nb}_{1-x} \mathrm{Ta}_{x}\right)_{2} \mathrm{O}_{9}$ shows satisfied properties of $\varepsilon_{\mathrm{r}} \approx 12.76, Q \times f$ value $\approx 442,000 \mathrm{GHz}$, and $\tau_{\mathrm{f}} \approx$ $-54 \mathrm{ppm} /{ }^{\circ} \mathrm{C}$, when $x=1$ and sintered at $1375{ }^{\circ} \mathrm{C}$ [208]. $\left(\mathrm{B}_{x} \mathrm{~W}_{1-x}\right)^{5+}$ substitution at $\mathrm{Nb}^{5+}$ site $(\mathrm{B}=\mathrm{Li}, \mathrm{Mg}, \mathrm{Al}, \mathrm{Ti})$ in $\mathrm{Mg}_{4} \mathrm{Nb}_{2} \mathrm{O}_{9}$-based ceramics revealed that the $\tau_{\mathrm{f}}$ depended on the distortion of the oxygen octahedra, while $\left(\mathrm{Ti}_{1 / 2} \mathrm{~W}_{1 / 2}\right)^{5+}$ substitution had the highest quality factor of 233,000 $\mathrm{GHz}$ [209]. The investigation of $y\left(\mathrm{Mg}_{0.95} \mathrm{Co}_{0.05}\right)_{4} \mathrm{Ta}_{2} \mathrm{O}_{9}-(1-y) \mathrm{CaTiO}_{3}$ ceramics provided a promising dielectric material for application with temperature stability, and the properties were shown as $\varepsilon_{\mathrm{r}} \approx 25.78, Q \times f$ value $\approx 200,000 \mathrm{GHz}$, and $\tau_{\mathrm{f}} \approx$ $-4.69 \mathrm{ppm} /{ }^{\circ} \mathrm{C}$ [210].

$\mathrm{Zn}_{3} \mathrm{Nb}_{2} \mathrm{O}_{8}$ was another promising binary niobite compound, which could be successfully produced with $98 \%$ theoretical density sintered at $1100{ }^{\circ} \mathrm{C}$ [211]. A two-stage sintering method was proposed to optimize the microstructure of $\mathrm{Zn}_{3} \mathrm{Nb}_{2} \mathrm{O}_{8}$ [212], where the sintering temperatures were 1150 and $1200{ }^{\circ} \mathrm{C}$ for the first time and the second sintering temperatures were 1050 and $1100{ }^{\circ} \mathrm{C}$, respectively. Sintered based on this approach, ceramics presented denser grain packing and less abnormal grain growth. Adding secondary phase into ceramics to compensate for $\tau_{\mathrm{f}}$ value would introduce a large amount of second phase, which were ascribed to the large dielectric loss. Aiming to reduce the defects stemmed from the secondary phase, layercofired ceramic architectures were designed such as $\mathrm{Zn}_{1.01} \mathrm{Nb}_{2} \mathrm{O}_{6} / \mathrm{TiO}_{2} / \mathrm{Zn}_{1.01} \mathrm{Nb}_{2} \mathrm{O}_{6}$ [3], $\mathrm{MgTiO}_{3} / \mathrm{TiO}_{2} / \mathrm{MgTiO}_{3}$ [4], and $\mathrm{Zn}_{3} \mathrm{Nb}_{2} \mathrm{O}_{8} / \mathrm{TiO}_{2} / \mathrm{Zn}_{3} \mathrm{Nb}_{2} \mathrm{O}_{8}$ [5]. High- $Q$ value was remained and temperature-stable MWDCs were obtained for all the reported tri-layer co-fired ceramics.

\section{3 Rock-salt structure}

Closely followed by the ever-growing explosion of global data volume and the rapid boost of millimeterwave technology, the requirement of materials with low permittivity $\left(\varepsilon_{\mathrm{r}} \leqslant 25\right)$ and high $Q \times f$ value is increasingly urgent. In the exploration of new composition ceramics, many rock-salt Li-containing compounds emerge as focal points. The general formula of rock-salt ceramics is $\mathrm{A}_{a} \mathrm{~B}_{b} \mathrm{O}_{a+b}\left(\mathrm{~A}^{+}=\mathrm{Li}, \mathrm{Na}\right.$; $\mathrm{B}^{4+}=\mathrm{Ti}, \mathrm{Sn}, \mathrm{Zr} ; \mathrm{B}^{5+}=\mathrm{Nb}$ and $\left.\mathrm{Ta}\right) . \mathrm{Li}_{2} \mathrm{TiO}_{3}$ underwent an order-disorder phase transition at $1213{ }^{\circ} \mathrm{C}$, in which the structure consisted of ordered (Li, Ti) layer, with the property of $\varepsilon_{\mathrm{r}} \approx 12.76, Q \times f$ value $\approx 44,200 \mathrm{GHz}$, and $\tau_{\mathrm{f}} \approx-54 \mathrm{ppm} /{ }^{\circ} \mathrm{C}$ [213]. The sintering behavior of excess $\mathrm{Li}$ for non-stoichiometry $\mathrm{Li}_{2+x} \mathrm{TiO}_{3}$ ceramics was investigated by Bian and Dong [214] and Hao et al. [215] after the determination of pseudo-binary of $\mathrm{Li}_{2} \mathrm{O}-\mathrm{TiO}_{2}$ [216,217]. For co-doped substitution, $\mathrm{Zn}_{1 / 3} \mathrm{Nb}_{2 / 3}$, $\mathrm{Mg}_{1 / 3} \mathrm{Nb}_{2 / 3}$, and $\mathrm{Co}_{1 / 3} \mathrm{Nb}_{2 / 3}$ addition into $\mathrm{Li}_{2} \mathrm{TiO}_{3}$ could adjust the $\tau_{\mathrm{f}}$ from positive to negative [218-220]. $\mathrm{Cu}_{1 / 3} \mathrm{Nb}_{2 / 3}$ doped ceramics with 3 wt $\% \mathrm{H}_{3} \mathrm{BO}_{3}$ were designed as a patch antenna and a dielectric resonator antenna [221]. The solid solution of $\mathrm{Li}_{2} \mathrm{TiO}_{3}-\mathrm{MgO}$ [222], $\mathrm{Li}_{2} \mathrm{TiO}_{3}-\mathrm{ZnO}[223,224]$, and $\mathrm{Li}_{2} \mathrm{TiO}_{3}-\mathrm{Li}_{3} \mathrm{NbO}_{4}$ [225] attracted much interest of researcher owing to their high quality factor. The primarily reported ceramics of $\mathrm{Li}_{2} \mathrm{O}-\mathrm{MgO} / \mathrm{ZnO} / \mathrm{CoO}-\mathrm{Ti} / \mathrm{Sn} / \mathrm{ZrO}_{2}$ ternary system contain $\mathrm{Li}_{2} \mathrm{Mg} / \mathrm{NiTi} / \mathrm{ZrO}_{4}, \mathrm{Li}_{2} \mathrm{Zn} / \mathrm{Mg} / \mathrm{CoTi}_{3} \mathrm{O}_{8}$, $\mathrm{Li}_{2} \mathrm{Zn} / \mathrm{Co} / \mathrm{Mg}_{3} \mathrm{Ti}_{4} \mathrm{O}_{12}, \mathrm{Li}_{2} \mathrm{Mg} / \mathrm{Ni}_{3} \mathrm{Ti} / \mathrm{SnO}_{6}, \mathrm{Li}_{2} \mathrm{ZnTi}_{5} \mathrm{O}_{12}$, $\mathrm{Li}_{2} \mathrm{Mg}_{4} \mathrm{TiO}_{7}, \mathrm{Li}_{6} \mathrm{Mg}_{7} \mathrm{Ti}_{3} \mathrm{O}_{16}, \mathrm{Li}_{4} \mathrm{MgSn}_{2} \mathrm{O}_{7}$, and $\mathrm{Li}_{2} \mathrm{NiZrO}_{4}$; while $\mathrm{LiZnNbO}_{4}, \mathrm{Li}_{3} \mathrm{Mg}_{2} \mathrm{NbO}_{6}$, and $\mathrm{Li}_{2} \mathrm{Mg}_{3} \mathrm{NbO}_{6}$ occupied the dominated composition of $\mathrm{Li}_{2} \mathrm{O}-\mathrm{MgO}$ / $\mathrm{ZnO} / \mathrm{CoO}-\mathrm{Nb} / \mathrm{Ta} / \mathrm{Sb}_{2} \mathrm{O}_{5}$. The microwave dielectric properties of the mentioned pure phase ceramics are listed in Table 1 [224,226-246], and the phase diagram of rock-salt structure is plotted in Fig. 8, where the ordered-disordered range was summarized from Zhang et al. [246,247]. Simultaneously, Gu et al. [248] stated the two-phase and thermally stable ceramics of $0.8 \mathrm{Li}_{3} \mathrm{NbO}_{4}-0.2 \mathrm{Ca}_{0.8} \mathrm{Sr}_{0.2} \mathrm{TiO}_{3}$, where the $\tau_{\mathrm{f}}$ value was $5.2 \mathrm{ppm} /{ }^{\circ} \mathrm{C}$.

\subsection{1 $\mathrm{Li}_{2} \mathrm{O}-\mathrm{MgO} / \mathrm{ZnO} / \mathrm{CoO}-\mathrm{Ti} / \mathrm{Sn} / \mathrm{ZrO}_{2}$ ternary system}

Secondary phases of $\mathrm{Mg}_{2} \mathrm{TiO}_{4}$ and $\mathrm{Li}_{2} \mathrm{Mg}_{3} \mathrm{Ti}_{4} \mathrm{O}_{12}$ were highly related to the properties when Yao et al. [249] prepared the $\mathrm{Li}_{2} \mathrm{MgTiO}_{4}$ after sintered higher than $1250{ }^{\circ} \mathrm{C}$. The variation of dielectric properties of $\mathrm{Li}_{2} \mathrm{Mg}_{0.95} \mathrm{~A}_{0.05} \mathrm{TiO}_{4}(\mathrm{~A}=\mathrm{Ni}, \mathrm{Co}, \mathrm{Mn}, \mathrm{Zn})$ indicated that the dielectric polarizability dominated the dielectric constant [250], and a near zero $\tau_{\mathrm{f}}\left(-4.03 \mathrm{ppm} /{ }^{\circ} \mathrm{C}\right)$ was obtained for $0.1 \mathrm{~mol} \mathrm{Zn}$ substitution for $\mathrm{Mg}$ [251]. 


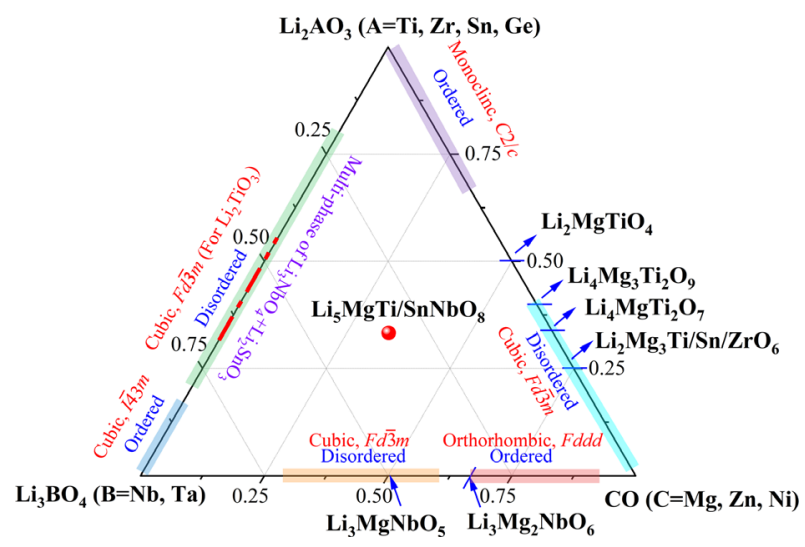

Fig. 8 Pseudo phase diagram of rock-salt structure.

Table 1 Microwave dielectric properties of pure phase with rock-salt structure

\begin{tabular}{|c|c|c|c|c|c|}
\hline Formula & $\varepsilon_{\mathrm{r}}$ & $Q \times f(\mathrm{GHz})$ & $\mathrm{f}\left(\mathrm{ppm} /{ }^{\circ} \mathrm{C}\right)$ & ST $\left({ }^{\circ} \mathrm{C}\right)$ & Ref. \\
\hline $\mathrm{Li}_{2} \mathrm{MgTiO}_{4}$ & 17.25 & 97,300 & -27.2 & 1360 & [226] \\
\hline $\mathrm{Li}_{2} \mathrm{NiTiO}_{4}$ & 19.25 & 51,290 & -20.1 & 1275 & [230] \\
\hline $\mathrm{Li}_{2} \mathrm{MgZrO}_{4}$ & 12.30 & 40,900 & -12.31 & 1175 & [234] \\
\hline $\mathrm{Li}_{2} \mathrm{MgTi}_{3} \mathrm{O}_{8}$ & 27.2 & 40,000 & 2.6 & 1000 & [227] \\
\hline $\mathrm{Li}_{2} \mathrm{CoTi}_{3} \mathrm{O}_{8}$ & 28.9 & 52,600 & 7.4 & 1025 & [228] \\
\hline $\mathrm{Li}_{2} \mathrm{ZnTi}_{3} \mathrm{O}_{8}$ & 25.6 & 90,000 & -10.8 & 1000 & [229] \\
\hline $\mathrm{Li}_{2} \mathrm{Co}_{3} \mathrm{Ti}_{4} \mathrm{O}_{12}$ & 21.4 & 35,000 & -22 & 1050 & [233] \\
\hline $\mathrm{Li}_{2} \mathrm{Mg}_{3} \mathrm{Ti}_{4} \mathrm{O}_{12}$ & 20.2 & 62,300 & -27.1 & 1125 & [232] \\
\hline $\mathrm{Li}_{2} \mathrm{Zn}_{3} \mathrm{Ti}_{4} \mathrm{O}_{12}$ & 20.6 & 106,700 & -48 & 1075 & [231] \\
\hline $\mathrm{Li}_{2} \mathrm{Mg}_{3} \mathrm{TiO}_{6}$ & 15.2 & 152,000 & -39 & 1280 & [235] \\
\hline $\mathrm{Li}_{2} \mathrm{Ni}_{3} \mathrm{TiO}_{6}$ & 13.18 & 9800 & -7.3 & 1275 & [238] \\
\hline $\mathrm{Li}_{2} \mathrm{Mg}_{4} \mathrm{TiO}_{7}$ & 13.43 & 233,600 & -7.24 & 1600 & [239] \\
\hline $\mathrm{Li}_{6} \mathrm{Mg}_{7} \mathrm{Ti}_{3} \mathrm{O}_{16}$ & 15.27 & 209,400 & -11.31 & 1550 & [240] \\
\hline $\mathrm{Li}_{2} \mathrm{ZnTi}_{5} \mathrm{O}_{12}$ & 38.4 & 54,300 & 82.9 & 1260 & [237] \\
\hline $\mathrm{Li}_{4} \mathrm{MgSn}_{2} \mathrm{O}_{7}$ & 12.4 & 58,754 & 12.1 & 1180 & [241] \\
\hline $\mathrm{Li}_{2} \mathrm{NiZrO}_{4}$ & 12.3 & 20,000 & -23.4 & 1300 & [242] \\
\hline $\mathrm{LiZnNbO}_{4}$ & 15.6 & 85,310 & -63.7 & 1070 & [236] \\
\hline $\mathrm{Li}_{3} \mathrm{Mg}_{2} \mathrm{NbO}_{6}$ & 14.94 & 100,965 & -21.96 & 1225 & [243] \\
\hline $\mathrm{Li}_{3} \mathrm{Mg}_{2} \mathrm{SbO}_{6}$ & 10.5 & 84,600 & -9.0 & 1300 & [244] \\
\hline $\mathrm{Li}_{2} \mathrm{Mg}_{3} \mathrm{NbO}_{6}$ & 16.8 & 79,642 & -22 & 1300 & [224] \\
\hline $\mathrm{Li}_{3} \mathrm{MgNbO}_{5}$ & 16.2 & 96,796 & -24.8 & 1260 & [245] \\
\hline
\end{tabular}

ST: sintering temperature $\left({ }^{\circ} \mathrm{C}\right)$.

Both $\mathrm{Li}_{2} \mathrm{Mg}_{4} \mathrm{TiO}_{7}$ and $\mathrm{Li}_{4} \mathrm{Mg}_{3} \mathrm{Ti}_{2} \mathrm{O}_{9}$ exhibited $\mathrm{LiFeO}_{2-}$ like cubic phase with space group $F m \overline{3} m$. The optimal combination of microwave dielectric properties of $\mathrm{Li}_{2}\left(\mathrm{Mg}_{0.9} \mathrm{~A}_{0.1}\right)_{4} \mathrm{TiO}_{7}(\mathrm{~A}=\mathrm{Co}, \mathrm{Ni}, \mathrm{Mg}, \mathrm{Zn}, \mathrm{Ca})$ was observed for $\mathrm{Zn}$ doped ceramics $\left(\varepsilon_{\mathrm{r}} \approx 14.77, Q \times f\right.$ value $\approx$ $162,200 \mathrm{GHz}$, and $\left.\tau_{\mathrm{f}} \approx-4.30 \mathrm{ppm} /{ }^{\circ} \mathrm{C}\right)$ and $\mathrm{Ca}\left(\varepsilon_{\mathrm{r}} \approx\right.$ $15.79, Q \times f$ value $\approx 100,300 \mathrm{GHz}$, and $\tau_{\mathrm{f}} \approx-1.43 \mathrm{ppm} /{ }^{\circ} \mathrm{C}$ ) [252]. Pure cubic $\mathrm{Li}_{4} \mathrm{Mg}_{3} \mathrm{Ti}_{2} \mathrm{O}_{9}$ phase was formed in the whole range of $0 \leqslant x \leqslant 0.4$ with $\mathrm{Mg}_{1 / 3} \mathrm{Ta}_{2 / 3}$ occupying Ti site [253].
Except for the sintering temperature, the heating rates and substation will directly influence the grain size, densification, and properties. Lu et al. [254] pointed out that the sintering rate increasing from 3 to $7{ }^{\circ} \mathrm{C} / \mathrm{min}$ would deteriorate the quality factor of $\mathrm{Li}_{2} \mathrm{ZnTi}_{3} \mathrm{O}_{8}$ ceramics. If ball milling is applied for the raw materials at first for $4 \mathrm{~h}$, then the sintering temperature of $\mathrm{Li}_{2} \mathrm{ZnTi}_{3} \mathrm{O}_{8}$ ceramics could reduce from 1075 to $925{ }^{\circ} \mathrm{C}$, and those ceramics were chemically compatible with Ag [255]. Sintering the ceramics in a box type electric furnace and in a microwave furnace would obtain $\mathrm{Li}_{2} \mathrm{ZnTi}_{3} \mathrm{O}_{8}$ ceramics with the grain size of 38 and $7 \mu \mathrm{m}$, respectively [256]. $\mathrm{Mg}, \mathrm{Co}$, and $\mathrm{Zn}$ substitution for $\mathrm{Zn}$ in $\mathrm{Li}_{2} \mathrm{ZnTi}_{3} \mathrm{O}_{8}$ increased the quality factor because of the more compact microstructure [257-259]. Whereas, the secondary phases were recorded after the introduction of $\mathrm{Sr}^{2+}$ or $\left(\mathrm{Sr}_{x} \mathrm{Ca}_{1-x}\right)$ into $\mathrm{Li}_{2} \mathrm{ZnTi}_{3} \mathrm{O}_{8}$ [260-262]. Phase evolution of $(1-x) \mathrm{Li}_{2} \mathrm{ZnTi}_{3} \mathrm{O}_{8}-x \mathrm{TiO}_{2}$ system indicated that pure $\mathrm{Li}_{2} \mathrm{ZnTi}_{3} \mathrm{O}_{8}$ with cubic structure was observed when $x \leqslant 0.2$ (the lattice parameter is similar to $\mathrm{MgFe}_{2} \mathrm{O}_{4}$ with space group of $F m \overline{3} m$ (227)), solid solution was exited in the range of $0.2 \leqslant x \leqslant 0.4$ with cubic structure (the lattice parameters is similar to $\mathrm{Zn}_{2} \mathrm{Ti}_{3} \mathrm{O}_{8}$ with space group of $P 4332$ (212)), and rutile $\mathrm{TiO}_{2}$ phase appeared when $x \geqslant$ 0.6 [263]. The $\tau_{\mathrm{f}}$ value moves from -15 to 102.4 in $(1-x) \mathrm{Li}_{2} \mathrm{ZnTi}_{3} \mathrm{O}_{8}-x \mathrm{TiO}_{2}(0 \leqslant x \leqslant 0.4)$ [264]; meanwhile, near zero $\tau_{\mathrm{f}}$ value was also achieved by Bari et al. [265] in this system. $4 \mathrm{wt} \% \mathrm{TiO}_{2}$ was added into $\mathrm{Li}_{2} \mathrm{ZnTi}_{3} \mathrm{O}_{8}$ with different particle sizes, where the nanoparticles and micron particles all generated a more uniform microstructure and relative density reached to $98.5 \%$ [266]. Similar to $\mathrm{TiO}_{2}$-doped $\mathrm{Li}_{2} \mathrm{ZnTi}_{3} \mathrm{O}_{8}$ ceramics, phase composition and properties of $\mathrm{Li}_{2} \mathrm{Mg}\left(\mathrm{Ti}_{1-x} \mathrm{Sn}_{x}\right)_{3} \mathrm{O}_{8}(x=$ $0.1-0.25)$ were concluded as with $0.10 \leqslant x \leqslant 0.15$, the spinel and rutile were co-exited; with $0.20 \leqslant x \leqslant$ 0.25 , the spinel, rutile, and ilmenite were obtained [267], and the optimal properties of $\mathrm{Li}_{2} \mathrm{ZnTi}_{3} \mathrm{O}_{8}$ $0.2 \mathrm{SnO}_{2}$ composite ceramics exhibited: $\varepsilon_{\mathrm{r}} \approx 20.9, Q \times f$ value $\approx 89,500 \mathrm{GHz}$, and $\tau_{\mathrm{f}} \approx-24 \mathrm{ppm} /{ }^{\circ} \mathrm{C}$ [268]. The variation of dielectric properties with density of $(1-x) \mathrm{Li}_{2}\left(\mathrm{Mg}_{0.95} \mathrm{Zn}_{0.05}\right)_{3} \mathrm{Ti}_{3} \mathrm{O}_{8}-x \mathrm{Li}_{2} \mathrm{TiO}_{3}(x=0.727,0.778$, 0.821 , and 0.889 ) was discussed systematically by Zhang et al. [269]. The concentration of oxygen vacancy, relative density, and decrease in damping behavior would influence the $Q \times f$ value of $\mathrm{Li}_{2} \mathrm{ZnTi}_{3} \mathrm{O}_{8}-x$ $\mathrm{wt} \% \mathrm{Nb}_{2} \mathrm{O}_{5}$ [270]. To trace the dielectric response of lattice vibration, the response process of dielectric loss in $\mathrm{Li}_{2} \mathrm{ZnTi}_{3-x} \mathrm{M}_{x} \mathrm{O}_{8}\left(\mathrm{M}=\mathrm{Al}^{3+}, \mathrm{Nb}^{5+},\left(\mathrm{Al}_{0.5} \mathrm{Nb}_{0.5}\right)^{4+}\right.$, 
$\left(\mathrm{Zn}_{1 / 3} \mathrm{Nb}_{2 / 3}\right)^{4+}$, and $\left.\left(\mathrm{Li}_{1 / 4} \mathrm{Nb}_{3 / 4}\right)^{4+}\right)$ was discussed systematically containing the conduction loss and lattice vibration loss [271]. The conduction loss which acts at frequency lower than terahertz is neglectful by researchers concentrating on MWDCs, while AC impedance analysis was used to identify the effect of dopants and the mechanism of conduction loss in this system. Combining the fitting $\mathrm{THz}$ time domain spectrum and far infrared reflectivity spectrum, the dielectric response was illustrated in depth based on lattice loss and conduction loss.

Ultra-low loss microwave dielectric materials of $\mathrm{Li}_{2} \mathrm{Mg}_{3} \mathrm{TiO}_{6}$-based ceramics are extensively studied via doping cations into $\mathrm{Mg}$ and $\mathrm{Ti}$ site. Bivalent cations [272] such as $\mathrm{Ca}^{2+}, \mathrm{Ni}^{2+}, \mathrm{Zn}^{2+}$, and $\mathrm{Mn}^{2+}$ were verified effectively to adjust the microwave dielectric properties for $\mathrm{Mg}$ site, and co-doped of $\mathrm{Al}_{1 / 2} \mathrm{Nb}_{1 / 2}$ and $\mathrm{Zn}_{1 / 3} \mathrm{Nb}_{2 / 3}$ for Ti-site enhanced the $Q \times f$ values to $174,300 \mathrm{GHz}$ [273] and 168,911 GHz [274], respectively. For MWDCs, compactness microstructure guarantees the satisfied microwave dielectric properties. However, porous microstructure caused by the loss of Li element under high temperature is a problem for all compounds containing Li. To cure the volatilization of lithium, Fang et al. [275-277] proposed a reliable method which provided the Li-rich sintering atmosphere, and they obtained serial MWDCs based on $\mathrm{Li}-\mathrm{Mg}-\mathrm{Sn} / \mathrm{Ti}$ oxides with excellent properties. The schematic representation of the devices provided with the Li-rich atmosphere is shown in Fig. 9, and this similar method was gradually popularized to other systems with volatilization element to obtain the ceramics with dense microstructure. The negative $\tau_{\mathrm{f}}$ values can be compensated by $\mathrm{Ca}_{0.8} \mathrm{Sr}_{0.2} \mathrm{TiO}_{3}$, and the sample with $0.91 \mathrm{Li}_{2} \mathrm{Mg}_{3} \mathrm{TiO}_{6}-0.09 \mathrm{Ca}_{0.8} \mathrm{Sr}_{0.2} \mathrm{TiO}_{3}$ showed a $\tau_{\mathrm{f}}$ value of $-3.65 \mathrm{ppm} /{ }^{\circ} \mathrm{C}$ [278].

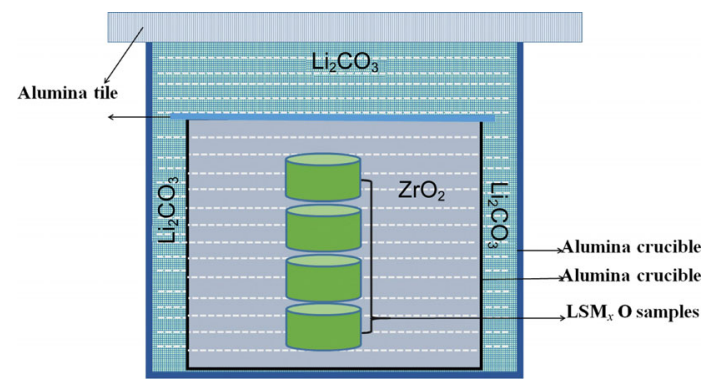

Fig. 9 Schematic representation of the $\mathrm{Li}_{2 /(1-x)} \mathrm{Sn}_{1 / 3(1-x)} \mathrm{Mg}_{x} \mathrm{O}$ $(x=0-4 / 7)$ placement for providing $\mathrm{ZrO}_{2}$-burying protective atmosphere and Li-rich sintering atmosphere. Reproduced with permission from Ref. [277], (C) The American Ceramic Society 2017.
The phase evolution of $\mathrm{Li}_{2} \mathrm{O}-3 \mathrm{MgO}-m \mathrm{TiO}_{2}(1 \leqslant$ $m \leqslant 6$ ) was summarized as the phase diagram shown in Fig. 10 [279], where the phase structures changed as $\left(\mathrm{Li}_{2} \mathrm{Mg}_{3} \mathrm{TiO}_{6}, m=1\right) \rightarrow\left(\mathrm{Li}_{2} \mathrm{Mg}_{3} \mathrm{Ti}_{4} \mathrm{O}_{12}\right.$ and $\mathrm{Mg}_{2} \mathrm{TiO}_{4}$, $m=2, \quad 3) \rightarrow\left(\mathrm{Li}_{2} \mathrm{Mg}_{3} \mathrm{Ti}_{4} \mathrm{O}_{12}, \quad m=4\right) \rightarrow\left(\mathrm{Li}_{2} \mathrm{Mg}_{3} \mathrm{Ti}_{4} \mathrm{O}_{12}\right.$, $\mathrm{MgTiO}_{3}$, and $\left.\mathrm{Li}_{2} \mathrm{MgTi}_{3} \mathrm{O}_{8}, \quad m=5\right) \rightarrow\left(\mathrm{Li}_{2} \mathrm{Mg}_{3} \mathrm{Ti}_{4} \mathrm{O}_{12}\right.$, $\mathrm{MgTiO}_{3}, \mathrm{Li}_{2} \mathrm{MgTi}_{3} \mathrm{O}_{8}$, and $\left.\mathrm{MgTi}_{2} \mathrm{O}_{5}, m=6\right)$. The application of $\mathrm{P}-\mathrm{V}-\mathrm{L}$ theory to $\mathrm{Li}_{2} \mathrm{MgTiO}_{4}$ [280], $\mathrm{Li}_{4} \mathrm{Mg}_{3} \mathrm{Ti}_{2} \mathrm{O}_{9}$ [281], and $\mathrm{Li}_{2} \mathrm{Mg}_{3} \mathrm{TiO}_{6}$ [282] revealed that the bond ionicity $\left(f_{\mathrm{i}}\right)$ descended as $f_{\mathrm{i}}(\mathrm{Ti}-\mathrm{O})>$ $f_{\mathrm{i}}(\mathrm{Mg}-\mathrm{O})>f_{\mathrm{i}}(\mathrm{Li}-\mathrm{O})$. As analogy with $\mathrm{Li}_{2} \mathrm{O}-3 \mathrm{MgO}-$ $m \mathrm{TiO}_{2}$ ceramics, $\mathrm{Li}_{2} \mathrm{ZrO}_{3}-\mathrm{MgO}$ ceramics were explored as well [234,283,284]. High quality factor could be obtained in $\left(\mathrm{Mg}_{1 / 3} \mathrm{Sb}_{2 / 3}\right)^{4+}$ substitutions for $\mathrm{Li}_{2} \mathrm{Mg}_{4} \mathrm{ZrO}_{7}$ ceramics, which reached 153,140 GHz [285]. Zirconium deficiency of $\mathrm{Li}_{2} \mathrm{Mg}_{3} \mathrm{Zr}_{1-x} \mathrm{O}_{6}$ ceramics was designed and remarkable dielectric properties were presented: $\varepsilon_{\mathrm{r}} \approx 13.13$, $Q \times f$ value $\approx 116,400 \mathrm{GHz}$, and $\tau_{\mathrm{f}} \approx-26.30 \mathrm{ppm} /{ }^{\circ} \mathrm{C}$ [286].

\subsection{2 $\mathrm{Li}_{2} \mathrm{O}-\mathrm{MgO} / \mathrm{ZnO} / \mathrm{CoO}-\mathrm{Nb} / \mathrm{Ta}_{2} \mathrm{O}_{5}$ ternary system}

An intermediate compound of $\mathrm{Li}_{3} \mathrm{Mg}_{2} \mathrm{NbO}_{6}$ at $x=1 / 3$ appeared in the investigation of structure evolution of $\mathrm{Li}_{(3-3 x)} \mathrm{M}_{4 x} \mathrm{Nb}_{(1-x)} \mathrm{O}_{4}(\mathrm{M}=\mathrm{Mg}, \mathrm{Zn})$, and the results indicated that solid solution could be formed in a wide range between $\mathrm{Li}_{3} \mathrm{NbO}_{4}$ and $\mathrm{MgO}$ [224]. Considering the existed compounds of $\mathrm{Li}_{2} \mathrm{TiO}_{3}-\mathrm{MgO}$ and $\mathrm{Li}_{3} \mathrm{NbO}_{4}-$ $\mathrm{MgO}$, Zhang et al. [246] supposed that a threecomponent solid solution would be formed in $\mathrm{Li}_{2} \mathrm{TiO}_{3}-$ $\mathrm{Li}_{3} \mathrm{NbO}_{4}-\mathrm{MgO}$, and the pseudo phase diagrams of those component were presented in Fig. 11. The most extensively studied ceramics in this system are $\mathrm{Li}_{2} \mathrm{Mg}_{3} \mathrm{Nb} / \mathrm{TaO}_{6}$ and $\mathrm{Li}_{3} \mathrm{Mg}_{2} \mathrm{NbO}_{6}$. For instance, a large grain size $(130 \mu \mathrm{m})$ was recorded after using reaction sintering process to generate $\mathrm{Li}_{3} \mathrm{Mg}_{2} \mathrm{NbO}_{6}$ [287]. Single cation doped solid solution of $\mathrm{Li}_{3}\left(\mathrm{Mg}_{1-x} \mathrm{Co}_{x}\right)_{2} \mathrm{NbO}_{6}$ [288], $\mathrm{Li}_{3}\left(\mathrm{Mg}_{1-x} \mathrm{Mn}_{x}\right)_{2} \mathrm{NbO}_{6}$ [289], $\mathrm{Li}_{3} \mathrm{Mg}_{2} \mathrm{Nb}_{1-x} \mathrm{Mo}_{x} \mathrm{O}_{6+x / 2}$ [290],

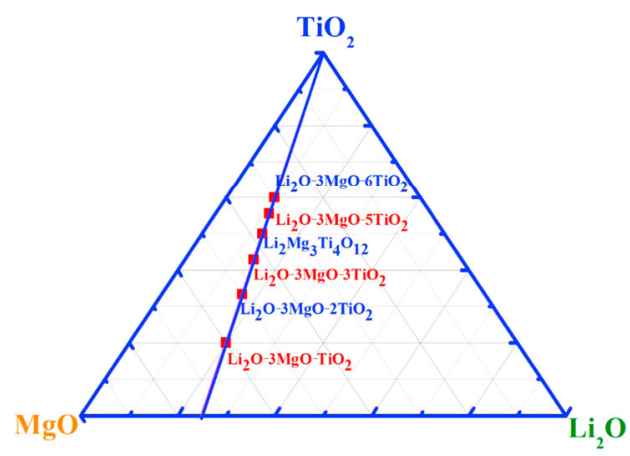

Fig. 10 Ternary phase diagram of $\mathrm{Li}_{2} \mathrm{O}-3 \mathrm{MgO}-m \mathrm{TiO}_{2}$ systems. Reproduced with permission from Ref. [279], (C) Elsevier Ltd and Techna Group S.r.1. 2016. 
$\mathrm{Li}_{3} \mathrm{Mg}_{2} \mathrm{Nb}_{1-x} \mathrm{Ta}_{x} \mathrm{O}_{6}$ [291], $\mathrm{Li}_{3} \mathrm{Mg}_{2} \mathrm{Nb}_{1-x} \mathrm{~V}_{x} \mathrm{O}_{6}$ [292], $\mathrm{Li}_{3} \mathrm{Mg}_{2} \mathrm{Sb}_{1-x} \mathrm{O}_{6} \quad$ [293], $\mathrm{Li}_{3} \mathrm{Mg}_{2-x} \mathrm{Zn}_{x} \mathrm{SbO}_{6} \quad$ [294], $\mathrm{Li}_{3} \mathrm{Mg}_{2}\left(\mathrm{Nb}_{1-x} \mathrm{~W}_{x}\right) \mathrm{O}_{6+x / 2}$ [295], $\mathrm{Li}_{3} \mathrm{Mg}_{2} \mathrm{Nb}_{1-x} \mathrm{Ti}_{x} \mathrm{O}_{6-x / 2}$ [296], $\mathrm{Li}_{3+x} \mathrm{Mg}_{2} \mathrm{Nb}_{1-x} \mathrm{Ti}_{x} \mathrm{O}_{6}$ [297], and $\mathrm{Li}_{3} \mathrm{Mg}_{2} \mathrm{Nb}_{0.96}\left(\mathrm{M}_{x} \mathrm{~W}_{1-x}\right)_{0.04} \mathrm{O}_{6}$ $\left(\mathrm{M}=\mathrm{Li}^{+}, \mathrm{Mg}^{2+}, \mathrm{Al}^{3+}, \mathrm{Ti}^{4+}\right)$ [298] or non-stoichiometric $\mathrm{Li}_{3} \mathrm{Mg}_{2+x} \mathrm{SbO}_{6}$ [299] have been probed and analyzed to explain the variation of dielectric properties through current theory including $\mathrm{P}-\mathrm{V}-\mathrm{L}$ theory, packing fraction, and $\mathrm{C}-\mathrm{M}$ equations. It was interesting that the "dark hole" phenomenon of $\mathrm{Li}_{2} \mathrm{TiO}_{3}$ was cured by adding $\mathrm{Li}_{3} \mathrm{Mg}_{2} \mathrm{NbO}_{6}$ and the $\tau_{\mathrm{f}}$ value of $0.96 \mathrm{Li}_{2} \mathrm{TiO}_{3}-$ $0.04 \mathrm{Li}_{3} \mathrm{Mg}_{2} \mathrm{NbO}_{6}$ was $2.6 \mathrm{ppm} /{ }^{\circ} \mathrm{C}$ [300]. Since yet there was no literature about the structure transformation of $\mathrm{Li}_{2} \mathrm{TiO}_{3}-\mathrm{Li}_{3} \mathrm{NbO}_{4}-\mathrm{MgO}$ to renew the understanding of rock-salt ceramics, Zhang et al. [247,301,302] gradually updated the reports about $\mathrm{Li}_{3} \mathrm{Mg}_{2} \mathrm{NbO}_{6}$-based ceramics. The phase transitions among the orthorhombic, cubic, and monoclinic were verified by XRD (Fig. 12) and TEM analysis (Fig. 13). The systematical analysis of lattice evolution and ordering transformation indicated that the low dielectric loss of this system was mainly ascribed to the superlattice. The $\mathrm{THz}$ time-domain spectroscopy was firstly used in this system to evaluate the intrinsic dielectric loss associated with phonon oscillation. Meanwhile, the configurational entropy was calculated to explain the change of disordered and ordered crystal structures, where the disordering cubic phase generated much larger configurational entropy than the ordered orthorhombic and monoclinic phase (Fig. 14).

(b)
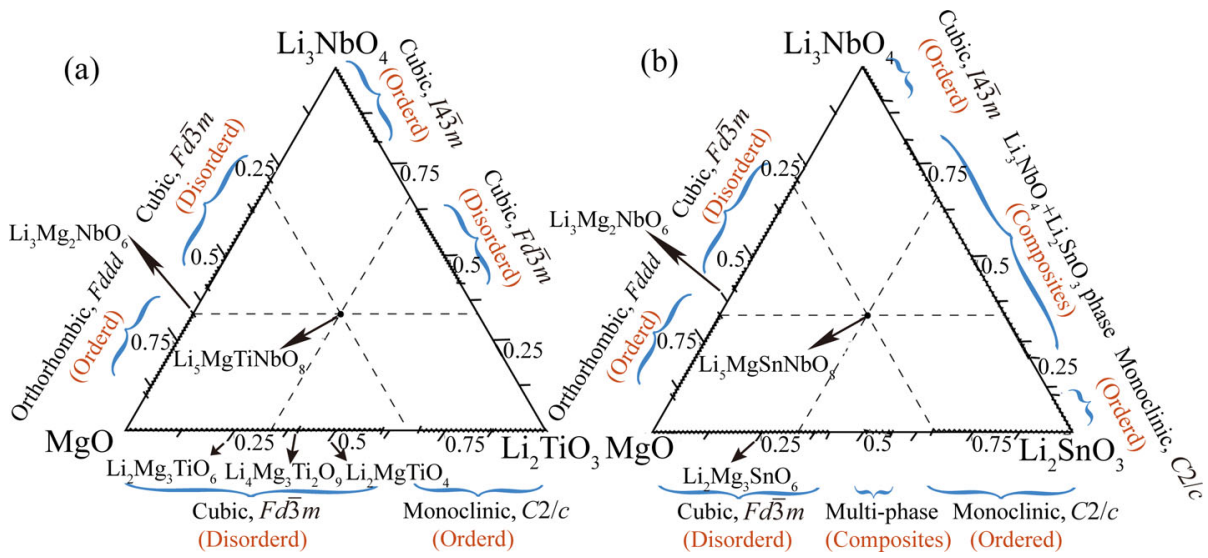

Fig. 11 Pseudo phase diagrams of (a) $\mathrm{Li}_{2} \mathrm{TiO}_{3}-\mathrm{Li}_{3} \mathrm{NbO}_{4}-\mathrm{MgO}$ and (b) $\mathrm{Li}_{2} \mathrm{SnO}_{3}-\mathrm{Li}_{3} \mathrm{NbO}_{4}-\mathrm{MgO}$ ternary systems. Reproduced with permission from Ref. [246], (C) Elsevier Ltd and Techna Group S.r.l. 2020.
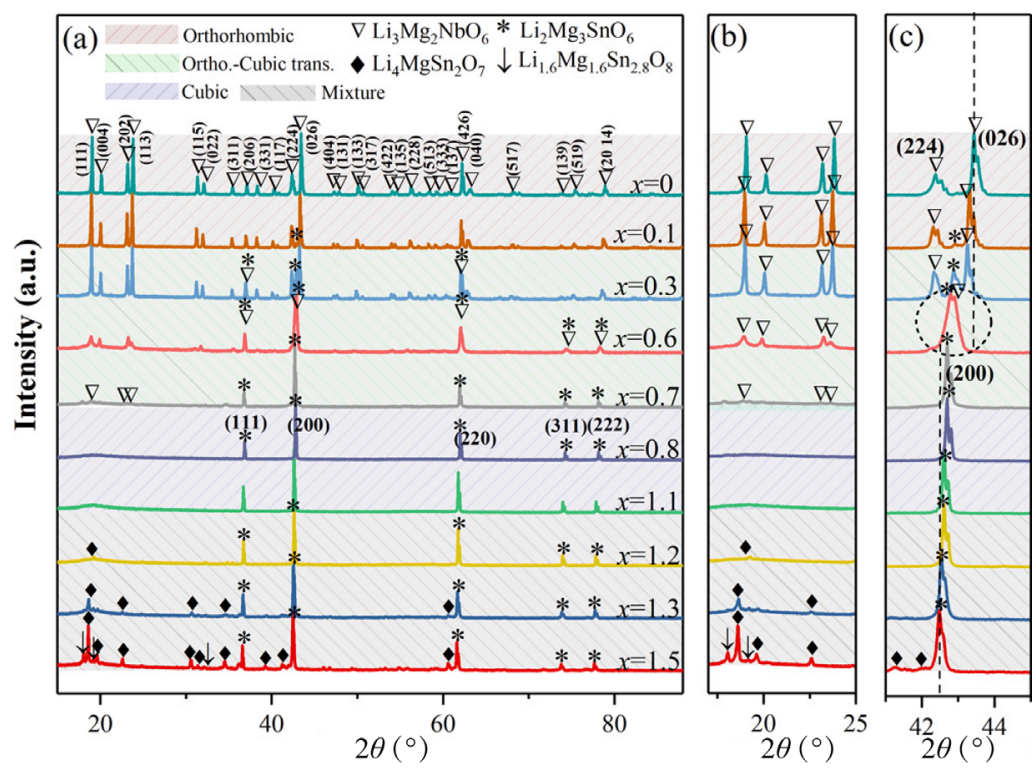

Fig. 12 (a) XRD patterns of $\mathrm{Li}_{3} \mathrm{Mg}_{2-x / 3} \mathrm{Sn}_{x} \mathrm{Nb}_{1-2 x / 3} \mathrm{O}_{6}(x=0-1.5)$ MWDCs sintered at $1290{ }^{\circ} \mathrm{C}$ for 4 h. (b) Amplified spectra of the XRD patterns from $17^{\circ}$ to $25^{\circ}$. (c) Amplified spectra of the XRD patterns from $41^{\circ}$ to $45^{\circ}$. Reproduced with permission from Ref. [302], (C) American Chemical Society 2020. 


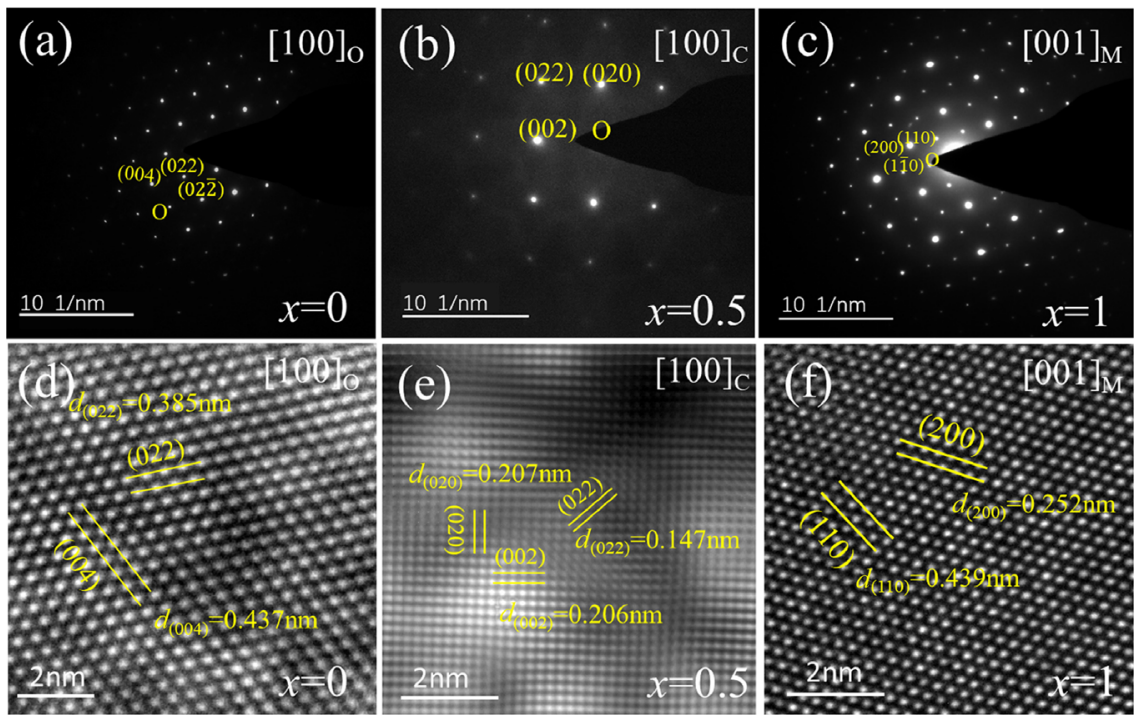

Fig. 13 Selected area electron diffraction (SAED) patterns of $\mathrm{Li}_{3+x} \mathrm{Mg}_{2-2 x} \mathrm{Nb}_{1-x} \mathrm{Ti}_{2 x} \mathrm{O}_{6}(0 \leqslant x \leqslant 1$ ) ceramics for (a) $x=0$ sample taken along $[100]_{\mathrm{O}}$ zone axis, (b) $x=0.5$ sample along $[100]_{\mathrm{C}}$ zone axis, and (c) $x=1$ sample along [001 $]_{\mathrm{M}}$ zone axis. $(\mathrm{d}-\mathrm{f})$ Corresponding high resolution transmission electron microscopy (HRTEM) images of the selected areas of the above samples. Reproduced with permission from Ref. [247], C Elsevier Ltd and Techna Group S.r.1. 2020.

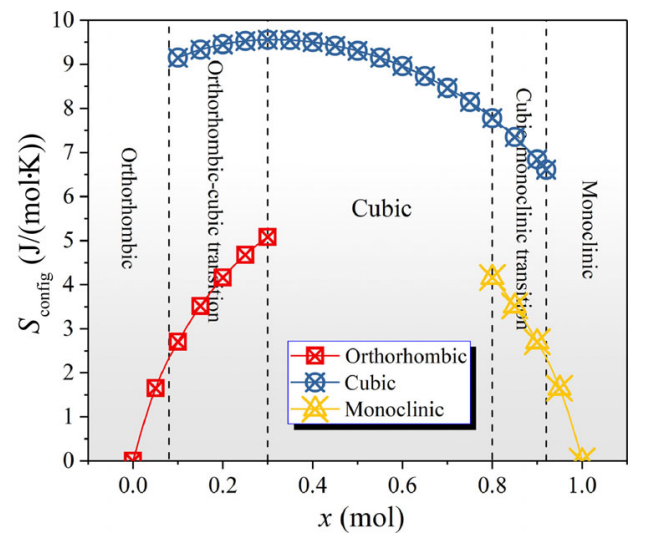

Fig. 14 Configurational entropy $\left(S_{\text {config }}\right)$ of the cation substitutions for the three different types of phases in the $\mathrm{Li}_{3+x} \mathrm{Mg}_{2-2 x} \mathrm{Nb}_{1-x} \mathrm{Ti}_{2 x} \mathrm{O}_{6}(0 \leqslant x \leqslant 1)$ system as a function of the substitution amount $(x)$. Reproduced with permission from Ref. [247], (C) Acta Materialia Inc. 2021.

In contrast to the large scale studies of $\mathrm{Li}_{3} \mathrm{Mg}_{2} \mathrm{NbO}_{6}$ based ceramics, only $\mathrm{Li}_{4} \mathrm{MgSn}_{(2-1.25 x)} \mathrm{Nb}_{x} \mathrm{O}_{7}(0 \leqslant x \leqslant$ 0.15) was reported to evaluate the change of microstructure in $\mathrm{Li}_{4} \mathrm{MgSn}_{2} \mathrm{O}_{7}$. The mean grain size of the doped ceramics ranged from 1.35 to $4.01 \mu \mathrm{m}$ and the cracks appeared along with the occurrence of the secondary phase [303].

\section{4 Tungsten bronze structure and titanate based on $\mathrm{BaO}-\mathrm{TiO}_{2}$}

Since 1970 , the exploration of $\mathrm{BaO}-\mathrm{TiO}_{2}$ system has been continuous renewed. Among them, $\mathrm{BaO}-4 \mathrm{TiO}_{2}$ and $2 \mathrm{BaO}-9 \mathrm{TiO}_{2}$ are the most extensively investigated ceramics as the representative ceramics with medium dielectric constant. The pseudo phase diagram of tungsten bronze structure and binary system based on $\mathrm{BaO}-\mathrm{TiO}_{2}$ system is shown in Fig. 15. In contrast to other sections in this review, the investigations about the compounds within this phase diagrams are relatively less, because the study of ceramics in $\mathrm{BaO}-\mathrm{R}_{2} \mathrm{O}_{3}-\mathrm{TiO}_{2} \quad(\mathrm{R}=\mathrm{La}-\mathrm{Gd})$ has been almost accomplished and widely used in the industry.

\subsection{1 $\mathrm{BaO}-\mathrm{TiO}_{2} / \mathrm{Nb}_{2} \mathrm{O}_{5} / \mathrm{Ta}_{2} \mathrm{O}_{5}$ system and $\mathrm{Re}_{2} \mathrm{TiO}_{5}$}

The frequency dependence of $Q \times f$ value was observed for $\mathrm{Ba}_{2} \mathrm{Ti}_{9} \mathrm{O}_{20}$ ceramics, which was ascribed to the extrinsic dielectric loss [304]. After adding $\mathrm{Sm}_{2} \mathrm{O}_{3}$ into $\mathrm{BaTi}_{4} \mathrm{O}_{9}$, precursor of $\mathrm{BaTi}_{4} \mathrm{O}_{9}$ and $\mathrm{BaSm}_{2} \mathrm{Ti}_{4} \mathrm{O}_{12}$ was

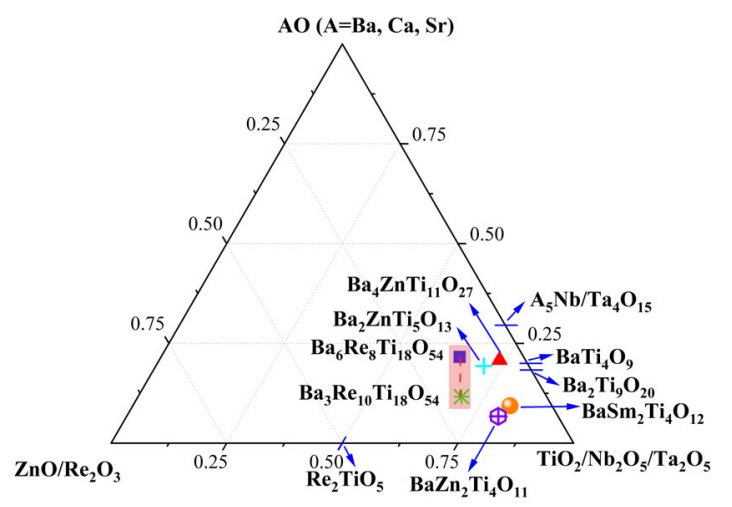

Fig. 15 Pseudo phase diagram of tungsten bronze structure and binary titanite. 
modeled by a cool iso-static press and calcined at $1300{ }^{\circ} \mathrm{C}$, and a near-zero temperature coefficient of $+2.2 \mathrm{ppm} /{ }^{\circ} \mathrm{C}$ was achieved with $40 \mathrm{~mol} \% \mathrm{Sm}_{2} \mathrm{O}_{3}$ [305]. $\left(\mathrm{Zn}_{1 / 3} \mathrm{Nb}_{2 / 3}\right)^{4+}$ substitution for $\mathrm{Ti}^{4+}$ in $\mathrm{Ba}_{2} \mathrm{Ti}_{9} \mathrm{O}_{20}$ modified the $\tau_{\mathrm{f}}$ value to $+7 \mathrm{ppm} /{ }^{\circ} \mathrm{C}$ [306]. Pseudobrookite-type $\mathrm{A}_{5} \mathrm{~B}_{4} \mathrm{O}_{15}(\mathrm{~A}=\mathrm{Ba}, \mathrm{Sr}, \mathrm{Mg}, \mathrm{Ca} ; \mathrm{B}=\mathrm{Nb}, \mathrm{Ta})$ was firstly investigated by Jawahar et al. [307], which showed $\varepsilon_{\mathrm{r}} \approx$ $11-51, Q \times f$ value $\approx 2400-88,000 \mathrm{GHz}$, and $\tau_{\mathrm{f}} \approx$ (-73)-232 ppm $/{ }^{\circ} \mathrm{C}$. Based on sol-gel method, $\mathrm{Mg}_{5} \mathrm{Nb}_{4} \mathrm{O}_{15}$ nano-powders were obtained at $600{ }^{\circ} \mathrm{C}$, and then the sintering temperature can be reduced to $1300{ }^{\circ} \mathrm{C}$ [204]. On the basis of $\mathrm{P}-\mathrm{V}-\mathrm{L}$ chemical bond theory, the relationship of chemical bond characteristic and microwave dielectric properties of $\mathrm{Eu}_{2} \mathrm{TiO}_{5}$ was discussed deeply [308]. Meanwhile, the electron localization function (ELF) based on the first-principles calculation was evaluated to provide the information of bond covalency [309], which provided a strategy to estimate the chemical bond characterization.

\subsubsection{Tungsten bronze structure}

The different compositions of tungstenbronze-type with $\mathrm{Ba}_{6-3 x} \mathrm{R}_{8+2 x} \mathrm{Ti}_{18} \mathrm{O}_{54}$ solid solution reported by Ohsato [310] in 2001, and the compounds were presented in Fig. 16. The relative permittivity of $\mathrm{BaO}-\mathrm{R}_{2} \mathrm{O}_{3}-\mathrm{TiO}_{2}(\mathrm{R}=\mathrm{La}-\mathrm{Gd})$ was higher than 80 , and the solid solubility region became narrower as the ionic radius of rare earth increasing [311]. The doping effect and the determination of crystal structure of $\mathrm{Ba}_{6-3 x} \mathrm{R}_{8+2 x} \mathrm{Ti}_{18} \mathrm{O}_{54}$ were summarized in the review of dielectric materials for wireless communication [1]. After 2010, there are only a few studies focused on this system. Three distinct phases were formed using variable size $\mathrm{TiO}_{2}$ reagents into $\mathrm{BaO}-\mathrm{Nd}_{2} \mathrm{O}_{3}-\mathrm{TiO}_{2}$ [312]. $\mathrm{Ba}_{6-3 x} \mathrm{R}_{8+2 x} \mathrm{Ti}_{18} \mathrm{O}_{54}$ (BRT, $\mathrm{R}=\mathrm{La}, \mathrm{Pr}, \mathrm{Nd}, \mathrm{Sm}$ )

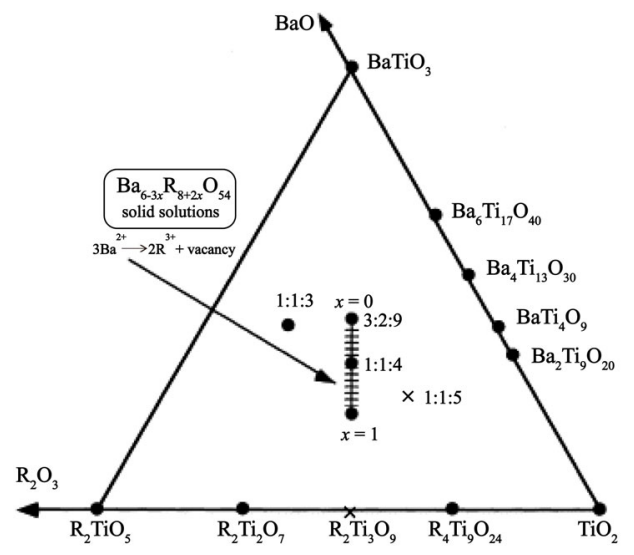

Fig. $16 \mathrm{BaO}-\mathrm{R}_{2} \mathrm{O}_{3}-\mathrm{TiO}_{2}(\mathrm{R}=$ rare earth $)$ ternary system. Reproduced with permission from Ref. [310], (C) Elsevier Science Ltd. 2001. solid solution family was reported with high permittivity. When $x=2 / 3, \mathrm{Ba}_{4} \mathrm{Nd}_{9.33} \mathrm{Ti}_{18} \mathrm{O}_{54}$ was regarded as the most investigated ceramics to lower its $\tau_{\mathrm{f}}$ value and sintering temperature or improve its $Q \times f$ value. Yao et al. [313] and Chen et al. [314] proposed that with $\mathrm{Al}_{2} \mathrm{O}_{3}$ added $\mathrm{BaO}-\mathrm{Nd}_{2} \mathrm{O}_{3}-\mathrm{TiO}_{3}$ ceramics, the $Q \times f$ value would increase obviously. The temperaturestable ceramics could be obtained by $\mathrm{Pb}$ and $\mathrm{Sr}$ substitution for $\mathrm{Ba}_{3.75} \mathrm{Nd}_{9.5} \mathrm{Ti}_{18} \mathrm{O}_{54}$ [315]; $\mathrm{Ba}_{4.5} \mathrm{Re}_{9} \mathrm{Ti}_{18} \mathrm{O}_{54}$ $(\mathrm{Re}=\mathrm{La}, \mathrm{Nd})$ [316]; solid solution of $\mathrm{Ba}_{4.2} \mathrm{Nd}_{9.2} \mathrm{Ti}_{18-x} \mathrm{Sn}_{x} \mathrm{O}_{54}$ [317], $\left(\mathrm{Ba}_{0.98} \mathrm{Sr}_{0.02}\right)_{3.75} \mathrm{Nd}_{9.5} \mathrm{Ti}_{18 x}\left(\mathrm{Zn}_{1 / 3} \mathrm{Nb}_{2 / 3}\right)_{x} \mathrm{O}_{54}$ [318], $\mathrm{Ba}_{6-3 x} \mathrm{Nd}_{8+2 x} \mathrm{Ti}_{18-y}\left(\mathrm{Cr}_{1 / 2} \mathrm{Nb}_{1 / 2}\right)_{y} \mathrm{O}_{54} \quad$ [319], $\mathrm{Ba}_{4} \mathrm{Nd}_{9.33}$ $\left(\mathrm{Al}_{0.5} \mathrm{Nb}_{0.5}\right)_{x} \mathrm{Ti}_{18-x} \mathrm{O}_{54}$ [320], $\mathrm{Ba}_{3.75} \mathrm{Nd}_{9.5} \mathrm{Ti}_{18-z}\left(\mathrm{Al}_{1 / 2} \mathrm{Nb}_{1 / 2}\right) \mathrm{O}_{54}$ [321], and $\mathrm{Ba}_{x} \mathrm{Sr}_{1-x} \mathrm{TiO}_{3}$ [322]; $\mathrm{NdAlO}_{3}$ [323] addition to $\mathrm{Ba}_{4} \mathrm{Sm}_{9.33} \mathrm{Ti}_{18} \mathrm{O}_{54} ; \mathrm{MgO}, \mathrm{Al}_{2} \mathrm{O}_{3}$, and $\mathrm{MnO}_{2}$ substituted for $\mathrm{Ti}^{4+}$ [324] in $\mathrm{Ba}_{4.2} \mathrm{Sm}_{9.2} \mathrm{Ti}_{18} \mathrm{O}_{54}, \mathrm{Ba}_{4} \mathrm{La}_{3.73} \mathrm{Sm}_{4.66} \mathrm{Bi}_{0.93} \mathrm{Ti}_{18} \mathrm{O}_{54}$, $\mathrm{Ba}_{4}\left(\mathrm{Pr}_{0.4} \mathrm{Sm}_{0.6}\right)_{28 / 3} \mathrm{Ti}_{18-y} \mathrm{Ga}_{4 y / 3} \mathrm{O}_{54}$ [325], and $\mathrm{Ba}_{4}\left(\mathrm{Pr}_{1-x}\right.$ $\left.\mathrm{Sm}_{x}\right)_{28 / 3} \mathrm{Al}_{4 y / 3} \mathrm{O}_{54}$ [326]. Among those reports, the analysis of Raman spectrum of $\mathrm{Ba}_{3.75} \mathrm{Nd}_{9.5} \mathrm{Ti}_{18-z}\left(\mathrm{Al}_{1 / 2} \mathrm{Nb}_{1 / 2}\right) \mathrm{O}_{54}$ enriched the theoretical study of tungstenbronze-type.

\subsection{3 $\mathrm{BaO}-\mathrm{ZnO}-\mathrm{TiO}_{2}$ system}

Ceramics based on the $\mathrm{BaO}-\mathrm{ZnO}-\mathrm{TiO}_{2}$ system have been concluded as $\mathrm{Ba}_{4} \mathrm{ZnTi}_{11} \mathrm{O}_{27}, \mathrm{BaZn}_{2} \mathrm{Ti}_{4} \mathrm{O}_{11}$, $\mathrm{Ba}_{2} \mathrm{ZnTi}_{5} \mathrm{O}_{13}$, and $\mathrm{Ba}_{x} \mathrm{Zn}_{x} \mathrm{Ti}_{8-x} \mathrm{O}_{16}$-hollandite [327]. The substitution of $\mathrm{Cu}$ for $\mathrm{Zn}$ dramatically increased the $Q \times f$ value because of the restrain of the formation of $\mathrm{Ti}^{3+}$ ions [328]. Considering the opposite $\tau_{\mathrm{f}}$ values of $\mathrm{BaTi}_{4} \mathrm{O}_{9}$ and $\mathrm{BaZn}_{2} \mathrm{Ti}_{4} \mathrm{O}_{11}$, the $\tau_{\mathrm{f}}$ values of composite ceramic based on those two phases varied gradually from 12 to $-13 \mathrm{ppm} /{ }^{\circ} \mathrm{C}$ [329]. $\mathrm{CuO}$ also worked as flux former to enhance the densification in the $\mathrm{BaTi}_{4} \mathrm{O}_{9}-$ $\mathrm{BaZn}_{2} \mathrm{Ti}_{4} \mathrm{O}_{11}$ composite ceramics, and the $0.85 \mathrm{BaTi}_{4} \mathrm{O}_{9}-$ $0.15 \mathrm{BaZn}_{2} \mathrm{Ti}_{4} \mathrm{O}_{11}-1 \mathrm{wt} \% \mathrm{CuO}$ presented the properties as $\varepsilon_{\mathrm{r}} \approx 36.4, Q \times f$ value $\approx 62,600 \mathrm{GHz}$, and $\tau_{\mathrm{f}} \approx$ $+0.2 \mathrm{ppm} /{ }^{\circ} \mathrm{C}$ [330]. Phase evolution of $\mathrm{BaZn}_{2} \mathrm{Ti}_{4} \mathrm{O}_{11}-$ $\mathrm{BaNd}_{2} \mathrm{Ti}_{4} \mathrm{O}_{12}$ ceramics was determined by $\mathrm{Yu}$ et al. [331], where $0.8 \mathrm{BaZn}_{2} \mathrm{Ti}_{4} \mathrm{O}_{11}-0.2 \mathrm{BaNd}_{2} \mathrm{Ti}_{4} \mathrm{O}_{12}$ ceramics possessed properties as $\varepsilon_{\mathrm{r}} \approx 39.1, Q \times f$ value $\approx 37,850 \mathrm{GHz}$, and $\tau_{\mathrm{f}} \approx-9 \mathrm{ppm} /{ }^{\circ} \mathrm{C}$.

\section{5 Perovskite related structure}

The ideal perovskite (written as $\mathrm{ABO}_{3}$ ) is cubically symmetric with a space group of $\operatorname{Pm} \overline{3} m$, and the represented material is $\mathrm{SrTiO}_{3}$. Due to the flexibility of $\mathrm{ABO}_{3}$ perovskite, variants of perovskite have been investigated, and the classification of perovskiterelated structure with representative structure is summarized in Fig. 17. The perovskite-related structure 


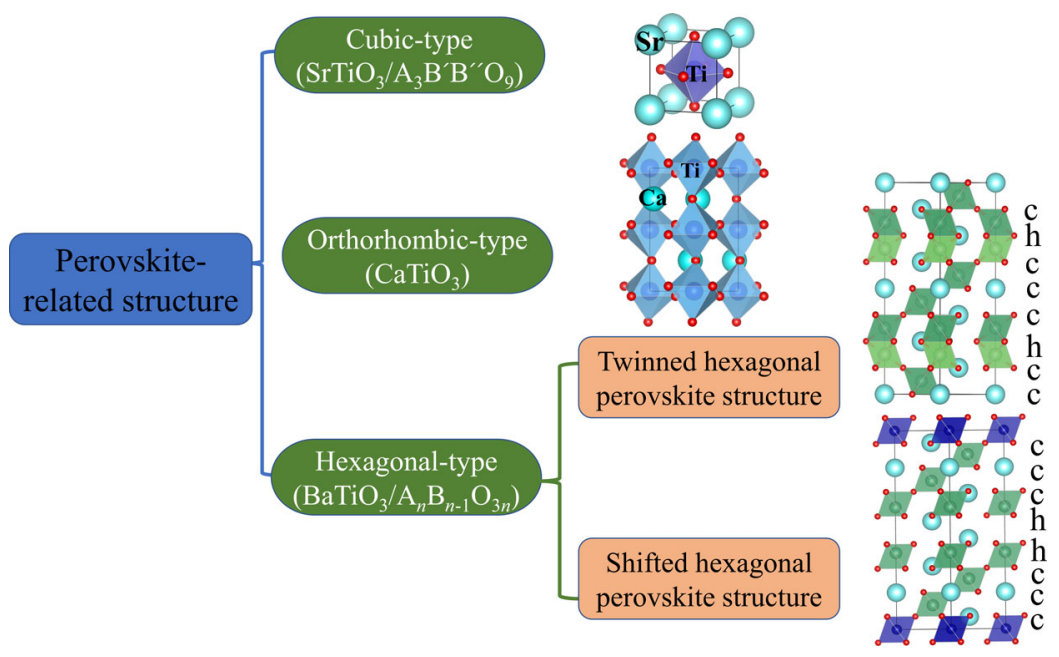

Fig. 17 Classification and the representative structure of perovskite-related structure.

contained cubic-type, orthorhombic-type, and hexagonaltype structures. For hexagonal-type structure, the twinned hexagonal structure means the closely packed $\mathrm{AO}_{3}$ layers were stacked in the order of $(\mathrm{ccch})_{2}$, while the shifted hexagonal structure corresponds to ccchhecc order. The typical representative of twinned structure is $\mathrm{Ba}_{8} \mathrm{CoTa}_{6} \mathrm{O}_{24}$ and the shifted structure is $\mathrm{Ba}_{8} \mathrm{CoNb}_{6} \mathrm{O}_{24}$ with eight-layer hexagonal perovskite structure [332]. The pseudo phase diagram of $\mathrm{ABO}_{3}$ and complex $\mathrm{ABO}_{3}$ type is provided in Fig. 18. From cubic and orthorhombic to hexagonal perovskite structure, researchers have proposed that tolerance factor, distortion of octahedron, and temperature of phase transition determined the variation of $\tau_{\mathrm{f}}$ value, and the ordered/ disordered cations were primarily related to quality factor.

\subsection{1 $\mathrm{ABO}_{3}$ formula}

This section contains the ceramics with a general

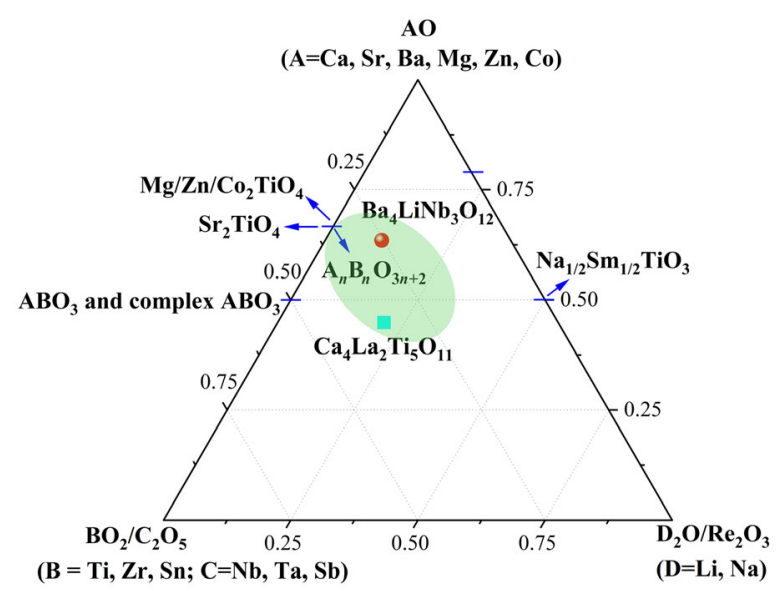

Fig. 18 Pseudo phase diagram of perovskite related structure. formula of $\mathrm{ABO}_{3}$ and their related structure or system. Perovskite family is entirely studied because of their pyro and piezo electricity, linear and non-linear electricoptic properties, and superconducting properties. A serials of investigation of $\mathrm{CaTiO}_{3}$ with $\mathrm{MgTiO}_{3}$-based [333-339], $\mathrm{LaAlO}_{3}$-based [340-347], $\mathrm{LaGaO}_{3}$ [348], $\mathrm{Re}\left(\mathrm{Zn}_{1 / 2} \mathrm{Ti}_{1 / 2}\right) \mathrm{O}_{3}$ [349], $\left(\mathrm{Mg}_{1-x} \mathrm{Zn}_{x}\right)_{1.8} \mathrm{Ti}_{1.1} \mathrm{O}_{4}$ [350], $\mathrm{BiSbO}_{4}$ [351], $\quad \mathrm{Nd}\left(\mathrm{Mg}_{0.4} \mathrm{Zn}_{0.1} \mathrm{Sn}_{0.5}\right) \mathrm{O}_{3}$ [352], $\mathrm{Sm}_{0.9} \mathrm{Nd}_{0.1} \mathrm{AlO}_{3}$ [353], $\mathrm{Ca}\left(\mathrm{Mg}_{1 / 3} \mathrm{Nb}_{2 / 3}\right) \mathrm{O}_{3}$ [354], $\left(\mathrm{Li}_{0.5} \mathrm{La}_{0.5}\right) \mathrm{TiO}_{3}$ [355], $\mathrm{Li}_{0.5} \mathrm{Nd}_{0.5} \mathrm{TiO}_{3}$ [356], $\mathrm{Li}_{0.5} \mathrm{Sm}_{0.5} \mathrm{TiO}_{3}$ [357], $\mathrm{Mg}_{0.95} \mathrm{Co}_{0.05} \mathrm{TiO}_{3}$ [335], (Sm,Nd) $\mathrm{AlO}_{3}$ [358-364], $\mathrm{Zn}_{2} \mathrm{SnO}_{4}$ [365], $\mathrm{Li}_{3} \mathrm{NbO}_{4}$ [248], $\mathrm{Ca}\left(\mathrm{Mg}_{1 / 3} \mathrm{Nb}_{2 / 3}\right) \mathrm{O}_{3}$ [366], $\mathrm{Sm}_{0.9} \mathrm{Nd}_{0.1} \mathrm{AlO}_{3}$ [367], $\mathrm{Na}_{0.5} \mathrm{Nd}_{0.5} \mathrm{TiO}_{3} \quad$ [368], $\mathrm{Nd}\left(\mathrm{Mg}_{1 / 2} \mathrm{Ti}_{1 / 2}\right) \mathrm{O}_{3} \quad$ [369,370], $\mathrm{Bi}_{0.5} \mathrm{Na}_{0.5} \mathrm{TiO}_{3} \quad$ [371], 3CaO- $-\mathrm{Re}_{2} \mathrm{O}_{3}-2 \mathrm{WO}_{3}$ system [372], $\mathrm{Ba}_{0.6} \mathrm{Sr}_{0.4} \mathrm{La}_{4} \mathrm{Ti}_{4} \mathrm{O}_{15}$ [373], $\mathrm{La}_{2} \mathrm{MgGeO}_{6}$ [374], $\left(\mathrm{Ca}_{0.8} \mathrm{Sr}_{0.2}\right)\left(\mathrm{Sn}_{x} \mathrm{Ti}_{1-x}\right) \mathrm{O}_{3}$ [375], $\mathrm{Ca}_{0.7} \mathrm{Ti}_{0.7} \mathrm{La}_{0.3}\left(\mathrm{Al}_{0.3-x} \mathrm{Ga}_{x}\right) \mathrm{O}_{3}$ [376], $\mathrm{Ca}_{(1-x)} \mathrm{Nd}_{2 x / 3} \mathrm{TiO}_{3}$ [377], $\mathrm{Ca}_{0.6} \mathrm{La}_{0.2667} \mathrm{TiO}_{3}$ [378], $\mathrm{Ca}_{0.6} \mathrm{La}_{0.267} \mathrm{Ti}_{1-x}\left(\mathrm{Nb}_{0.5} \mathrm{Ga}_{0.5}\right)_{x} \mathrm{O}_{3} \quad$ [379], $\mathrm{Ca}_{0.6} \mathrm{Nd}_{0.8 / 3} \mathrm{TiO}_{3}-$ $\left(\mathrm{Li}_{0.5} \mathrm{Nd}_{0.5}\right) \mathrm{TiO}_{3} \quad$ [380], $\mathrm{Ca}_{0.4-x} \mathrm{Mg}_{x} \mathrm{Sm}_{0.4} \mathrm{TiO}_{3} \quad$ [381], $\mathrm{CaTi}_{1-x}\left(\mathrm{Nb}_{0.5} \mathrm{Ga}_{0.5}\right)_{x} \mathrm{O}_{3}$ [382], $\mathrm{Ca}_{0.66} \mathrm{Ti}_{0.66} \mathrm{Sm}_{0.34} \mathrm{Al}_{0.34} \mathrm{O}_{3}$ [383], $\mathrm{Ca}_{0.66} \mathrm{Ti}_{0.66} \mathrm{Nd}_{0.34} \mathrm{Al}_{0.34} \mathrm{O}_{3}$ [384], $\mathrm{CaTi}_{1-x}\left(\mathrm{Al}_{0.5} \mathrm{Nb}_{0.5}\right)_{x} \mathrm{O}_{3}$ [385,386], $\mathrm{Ca}_{0.6} \mathrm{La}_{0.8 / 3}\left(\mathrm{Sn}_{x} \mathrm{Ti}_{1-x}\right) \mathrm{O}_{3}$ [387], $\mathrm{Ca}_{(1-3 x / 2)} \mathrm{Ce}_{x} \mathrm{TiO}_{3}$ [388], $\quad \mathrm{Ca}_{0.35} \mathrm{Li}_{0.25} \mathrm{Nd}_{0.35} \mathrm{Ti}_{1-x}\left(\mathrm{Zn}_{1 / 3} \mathrm{Ta}_{2 / 3}\right)_{x} \mathrm{O}_{3} \quad$ [389], $\mathrm{Ca}_{0.61} \mathrm{Nd}_{0.26} \mathrm{Ti}_{1-x} \mathrm{Cr}_{x} \mathrm{O}_{3} \quad$ [390], $\mathrm{CaTi}_{1-x}\left(\mathrm{Mg}_{1 / 2} \mathrm{~W}_{1 / 2}\right)_{x} \mathrm{O}_{3}$ [391], and $\mathrm{Ca}\left(\mathrm{Hf}_{x} \mathrm{Ti}_{1-x}\right) \mathrm{O}_{3}$ [392] ceramics have been reported thoroughly. Different thermally treated methods to minimize the dielectric loss for $\mathrm{CaTiO}_{3}$ were proposed by $\mathrm{Hu}$ et al. [393]. The dielectric constant values saturated at 7.7-8.5 of $\mathrm{Ca}_{0.8} \mathrm{Sr}_{0.2} \mathrm{SnO}_{3}$ ceramics in the sintering temperature range of $1450-1540{ }^{\circ} \mathrm{C}$ [394]. $0.4 \mathrm{Nd}_{2.94 / 3} \mathrm{Ba}_{0.03}\left(\mathrm{Mg}_{0.5} \mathrm{Sn}_{0.5}\right) \mathrm{O}_{3}-0.6 \mathrm{Ca}_{0.8} \mathrm{Sr}_{0.2} \mathrm{TiO}_{3}$ ceramics modified the $\tau_{\mathrm{f}}$ value to $-7 \mathrm{ppm} /{ }^{\circ} \mathrm{C}$ when sintered at $1600{ }^{\circ} \mathrm{C}$ [395]. Although numbers of 
investigations about optimizing the properties of $\mathrm{CaTiO}_{3}$ ceramics have been reported, the vibrational characteristic of $\mathrm{CaTiO}_{3}$ was verified by Shi et al. [396] in 2020.

For solid solution of $\mathrm{Ba}\left[\mathrm{Ti}_{0.4} \mathrm{Ga}_{0.3} \mathrm{Nb}_{0.3(1-x)} \mathrm{Sb}_{0.3 x}\right] \mathrm{O}_{3}$, a near zero $\tau_{\mathrm{f}}$ value of $-1.1 \mathrm{ppm} /{ }^{\circ} \mathrm{C}$ was obtained with $x=0.5$ [397], while a $\tau_{\mathrm{f}}$ value of $8.2 \mathrm{ppm} /{ }^{\circ} \mathrm{C}$ was achieved for $\left(\mathrm{Sr}_{0.2} \mathrm{Ga}_{0.488} \mathrm{Nd}_{0.208}\right) \mathrm{Ti}_{1-x} \mathrm{Ga}_{4 x / 3} \mathrm{O}_{3}$ with $x=$ 0.5 [398]. A dramatical decrease of $\tau_{\mathrm{f}}$ value from 1171 to $-82 \mathrm{ppm} /{ }^{\circ} \mathrm{C}$ was obtained for $\operatorname{Sr}\left(\mathrm{Zr}_{x} \mathrm{Ti}_{1-x}\right) \mathrm{O}_{3}$ [399]. In the chemical formula of $\mathrm{SrO}\left(\mathrm{Sr}_{1-x} \mathrm{Ba}_{x} \mathrm{TiO}_{3}\right)_{n}(x=0$, $0.5 ; n=1-4)$, it is demonstrated that samples with $n=$ 1,2 had no dielectric non-linear behavior in the temperature range of $(-165)-50{ }^{\circ} \mathrm{C}$, while the tunability increased with $n$ increasing [400]. Two second phases containing $\mathrm{BaWO}_{4}$ and $\mathrm{Ba}_{2} \mathrm{Ti}_{5} \mathrm{O}_{12}$ were observed in $\mathrm{Ba}_{0.5} \mathrm{Sr}_{0.5} \mathrm{Ti}_{-3 y / 2} \mathrm{~W}_{y} \mathrm{O}_{3}$ system with $y \geqslant$ 0.02 [401], and $\mathrm{BaTiSiO}_{5}$ phase was indexed in $\mathrm{Ba}_{0.4} \mathrm{Sr}_{0.6} \mathrm{Ti}_{1-y} \mathrm{Si}_{y} \mathrm{O}_{3}$ [402]. The dielectric constant can be adjusted apparently in the $\mathrm{Ba}_{0.4} \mathrm{Sr}_{0.6} \mathrm{TiO}_{3}-\mathrm{BaMoO}_{4}$ and $\mathrm{Ba}_{0.5} \mathrm{Sr}_{0.5} \mathrm{TiO}_{3}-\mathrm{AMoO}_{4}(\mathrm{~A}=\mathrm{Ba}, \mathrm{Sr})$ composite ceramics, where only cubic perovskite structure and scheelite structure were detected $[403,404]$. However, the $\mathrm{BaMoO}_{4}$ was observed when $\mathrm{MgMoO}_{4}$ added into $\mathrm{Ba}_{0.5} \mathrm{Sr}_{0.5} \mathrm{TiO}_{3}$ [405]. Adding $\mathrm{Zr}_{0.8} \mathrm{Sn}_{0.2} \mathrm{TiO}_{4}$ into $\mathrm{Ba}_{0.4} \mathrm{Sr}_{0.6} \mathrm{TiO}_{3}$, the dielectric constant and dielectric loss increased with the increase of the content of $\mathrm{Zr}_{0.8} \mathrm{Sn}_{0.2} \mathrm{TiO}_{4}$ [406]. Adding $\mathrm{Fe}$ power in $\mathrm{Ba}_{0.4} \mathrm{Sr}_{0.6} \mathrm{TiO}_{3}$ ceramics indicated that the appearance of $\mathrm{Fe}^{2+}$ and $\mathrm{Fe}^{3+}$ would decrease the $\mathrm{O}$ vacancy concentrations and enhance the microwave dielectric properties [407]. In the ternary system of $\mathrm{Ba}_{0.5} \mathrm{Sr}_{0.5} \mathrm{TiO}_{3}-$ $\mathrm{MgO}-\mathrm{Mg}_{2} \mathrm{TiO}_{4}$ [408], $\mathrm{Ba}_{0.5} \mathrm{Sr}_{0.5} \mathrm{TiO}_{3}-\mathrm{MgO}-\mathrm{Mg}_{2} \mathrm{SiO}_{4}$ [409], and $(1-x-y) \mathrm{BaTiO}_{3}-x \mathrm{Cr}_{2} \mathrm{Ti}_{3} \mathrm{O}_{9}-y \mathrm{Bi}_{2} \mathrm{O}_{3}$ [410], the dielectric constant reduced with more $\mathrm{Mg}_{2} \mathrm{TiO}_{4}$ and $\mathrm{Mg}_{2} \mathrm{SiO}_{4}$, while solid solution was observed with $\mathrm{Cr}^{3+}$ and $\mathrm{Bi}^{3+}$ into $\mathrm{BaTiO}_{3}$. Co-doping $\mathrm{ZnO}, \mathrm{Al}_{2} \mathrm{O}_{3}$, and $\mathrm{MgO}$ on the $\mathrm{Ba}_{0.66} \mathrm{Sr}_{0.4} \mathrm{TiO}_{3}$ would generate $\mathrm{Mg}(\mathrm{Zn}) \mathrm{Al}_{2} \mathrm{O}_{4}$ as the secondary phase [411]. The lattice vibrations of $\mathrm{Ba}_{0.4} \mathrm{Sr}_{0.6} \mathrm{TiO}_{3}$ ceramics were systematically investigated by Jiang et al. [412] after Mn substituted for $\mathrm{Sr}$. $\mathrm{Zr}$ and Sn doped into $\mathrm{Ba}_{0.1} \mathrm{Mg}_{0.9} \mathrm{TiO}_{3}$ ceramic would bring about $\mathrm{Ba}_{2} \mathrm{Ti}_{9} \mathrm{O}_{20}$ and $\mathrm{BaTi}_{5} \mathrm{O}_{11}$ [413]. Similar to $\mathrm{CaTiO}_{3}$, the effect of $\mathrm{LnAlO}_{3}(\mathrm{Ln}=\mathrm{Sm}, \mathrm{Nd})$ on $\mathrm{BaTiO}_{3}$-based ceramics was systematically studied by Liu et al. [414] and Xie et al. [415]. Solid solution of $\mathrm{Ba}_{x} \mathrm{Mg}_{1-x} \mathrm{Ti}_{0.95} \mathrm{Sn}_{0.05} \mathrm{O}_{3}$ [416] and local 1:1 ordering in B-site of $\operatorname{Sr}\left(\mathrm{Ga}_{0.5} \mathrm{Nb}_{0.5}\right)_{1-x} \mathrm{Ti}_{x} \mathrm{O}_{3}$ was verified by TEM and Raman spectroscopy, and the decline of quality factor stemmed from the anharmonicity by $\mathrm{Ti}$ substitution [417]. $0.2 \mathrm{SrTiO}_{3}-0.8 \mathrm{Ca}_{0.61} \mathrm{Nd}_{0.26} \mathrm{Ti}_{1-x} \mathrm{Al}_{4 x / 3} \mathrm{O}_{3}$ ceramics also reached a near zero $\tau_{\mathrm{f}}$ value with $x=0.5$ [418]. $(1-x) \mathrm{Mg}\left(\mathrm{Ti}_{0.95} \mathrm{Sn}_{0.05}\right) \mathrm{O}_{3}-x \mathrm{BaTiO}_{3}$ compounds experienced a phase transition of tetragonal-structure $\mathrm{BaTiO}_{3}$, monoclinic-structure $\mathrm{Ba}_{4} \mathrm{Ti}_{11} \mathrm{O}_{26}$, and triclinic-structure $\mathrm{Ba}_{2} \mathrm{Ti}_{9} \mathrm{O}_{20}$ [419]. Likewise, $\mathrm{Sr}_{(1-1.5 x)} \mathrm{Ce}_{x} \mathrm{TiO}_{3} \quad(x=$ 0.1-0.67) ceramics changed from cubic, tetragonal, to orthorhombic, and the dielectric behaviors were dominated by oxygen vacancies and defect dipoles [420]. Tian et al. $[421,422]$ reported that $\left(\mathrm{Co}_{0.5} \mathrm{~W}_{0.5}\right)^{4+}$ and $\left(\mathrm{Zn}_{0.5} \mathrm{~W}_{0.5}\right)^{4+}$ occupying the Ti-site in $\mathrm{BaTiO}_{3}$ would render the $\tau_{\mathrm{f}}$ value change from positive to negative. $\mathrm{BaWO}_{4}$ phase appeared in $\mathrm{Ba}_{1-x} \mathrm{Sr}_{x}\left(\mathrm{Mg}_{0.5} \mathrm{~W}_{0.5}\right) \mathrm{O}_{3}$ ceramics and $\mathrm{Ba}_{2} \mathrm{Mg}_{0.95} \mathrm{Zn}_{0.05} \mathrm{WO}_{6}$, and the grain size distributed in a narrow range around $0.8 \mu \mathrm{m}[423,424]$. A $\tau_{\mathrm{f}}$ value of $-2.4 \mathrm{ppm} /{ }^{\circ} \mathrm{C}$ was achieved for B-site deficient $\mathrm{Ba}\left(\mathrm{Mg}_{(1-x) / 2} \mathrm{Y}_{x / 3} \square_{x / 6} \mathrm{~W}_{1 / 2}\right) \mathrm{O}_{3}$ [425]. In the nonstoichiometric system of $\left(\mathrm{Sr}_{0.4} \mathrm{Ce}_{0.4}\right)_{1-x} \mathrm{Nd}_{x} \mathrm{Ti}_{0.8} \mathrm{Mg}_{0.2} \mathrm{O}_{3}$, solid solution was obtained when $x \leqslant 0.2$, while the satisfied properties were $\varepsilon_{\mathrm{r}} \approx 53, Q \times f$ value $\approx$ $26,700 \mathrm{GHz}$, and $\tau_{\mathrm{f}} \approx+2.8 \mathrm{ppm} /{ }^{\circ} \mathrm{C}$ with $x=0.4$ [426]. Meanwhile, compositional dependence of microwave dielectric properties of doped $\mathrm{SrTiO}_{3}$ sintered in air is presented as Fig. 19. It was demonstrated that $\mathrm{SrTiO}_{3}$ added into $\mathrm{ZnAl}_{2} \mathrm{O}_{4}-3 \mathrm{Zn}_{2} \mathrm{SiO}_{4}-2 \mathrm{SiO}_{2}$ could reduce the sintering temperature from 1320 to $1180-1200{ }^{\circ} \mathrm{C}$ [427].

With the same general formula of $\mathrm{ABO}_{3}$, the investigations of $\mathrm{NdGaO}_{3}, \mathrm{NdNbO}_{3}$, and $\mathrm{AgTa} / \mathrm{NbO}_{3}$ are listed adjacently to $\mathrm{CaTiO}_{3}$ and $\mathrm{SrTiO}_{3}$. Phase composition was identified for $\mathrm{NdGaO}_{3}-\mathrm{Bi}_{0.5} \mathrm{Na}_{0.5} \mathrm{TiO}_{3}$ system, and new temperature-stable ceramics with $0.4 \mathrm{NdGaO}_{3}-0.6 \mathrm{Bi}_{0.5} \mathrm{Na}_{0.5} \mathrm{TiO}_{3}$ was obtained [428]. Order-disorder transformation of A-site-deficient perovskites plays a significant role in conductivity of materials. The investigation of crystal structure and dielectric properties of the $\mathrm{Nd}_{(1-x) / 3} \mathrm{M}_{x} \mathrm{NbO}_{3}(\mathrm{M}=\mathrm{Li}$, $\mathrm{Ag} ; 0 \leqslant x \leqslant 0.2)$ suggested that the dielectric loss majored by the lithium or silver ionic conduction at low frequencies [429]. Solid solution of $\mathrm{AgNb} / \mathrm{TaO}_{3}$ based ceramics was then studied extensively $[430,431]$. Temperature-stable MWDCs with the formula of $(\mathrm{La}, \mathrm{Nd})_{2 / 3} \mathrm{TiO}_{3}$ were studied by Saleem et al. [432].

$\mathrm{MgTiO}_{3}$ also belongs to the general formula of $\mathrm{ABO}_{3}$. The substitution for $\mathrm{MgTiO}_{3}$ such as $\mathrm{Ni}, \mathrm{Zn}, \mathrm{Co}$, and $\mathrm{Mn}$ for $\mathrm{Mg}$ has been investigated systematically [433-436], where $\left(\mathrm{Mg}_{1-x} \mathrm{Co}_{x}\right) \mathrm{TiO}_{3}$ ceramics were crystalized as ilmenite structure when $x \leqslant 0.5$, and the 


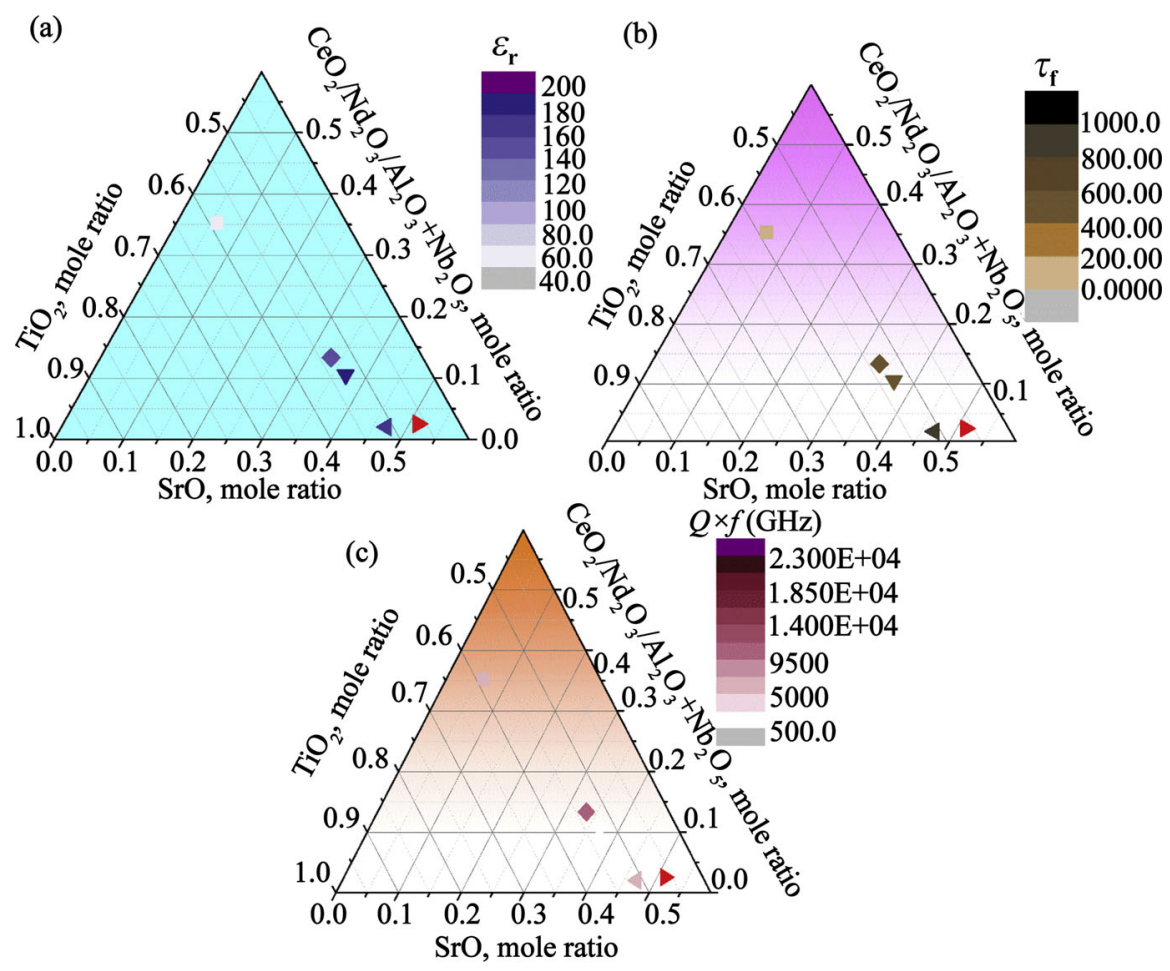

Fig. 19 Compositional dependence of microwave dielectric characteristics of $\mathrm{Nd}_{2} \mathrm{O}_{3}, \mathrm{CeO}_{2}, \mathrm{Al}_{2} \mathrm{O}_{3}$, and $\mathrm{Nb}_{2} \mathrm{O}_{3}$ doped $\mathrm{SrTiO}_{3}$ compound sintered in air, closed pipe, and nitrogen atmosphere with (a) relative permittivity $\left(\varepsilon_{\mathrm{r}}\right)$, (b) TCF $\left(\tau_{\mathrm{f}}\right)$, and (c) $Q \times f$ value, respectively. Reproduced with permission from Ref. [426], (C) The Chinese Ceramic Society 2020.

secondary phase was detected with more doping cations [437]. $\left(\mathrm{Zn}_{1-x} \mathrm{Mg}_{x}\right) \mathrm{TiO}_{3}$ was prepared and demonstrated that the dielectric constant and loss decreased with $\mathrm{Mg}$ increase [438]. For Sn doped into Ti site in $\mathrm{MgTiO}_{3}$, in the range of $x=0.05-0.07$, the ceramics exhibited excellent microwave dielectric properties of $\varepsilon_{\mathrm{r}} \approx 16.8-17.1, Q \times f$ value $\approx 298,000$ $312,000 \mathrm{GHz}$, and $\tau_{\mathrm{f}} \approx(-53)-(-50) \mathrm{ppm} /{ }^{\circ} \mathrm{C}$ [439]. $\mathrm{Mg}_{0.95} \mathrm{Co}_{0.05} \mathrm{TiO}_{3}$ ceramics possessed properties as $\varepsilon_{\mathrm{r}} \approx$ 17.03, $Q \times f$ value $\approx 170 \mathrm{THz}$, and $\tau_{\mathrm{f}} \approx-40 \mathrm{ppm} /{ }^{\circ} \mathrm{C}$ when prepared by Semi Alkoxide precursor method [440]. Gong et al. [441] obtained $\operatorname{Mg}\left(\mathrm{Sn}_{0.05} \mathrm{Ti}_{0.95}\right) \mathrm{O}_{3}$ ceramics with microwave dielectric properties $\varepsilon_{\mathrm{r}} \approx 17.6$, $Q \times f$ value $\approx 328,543 \mathrm{GHz}$, and $\tau_{\mathrm{f}} \approx-42 \mathrm{ppm} /{ }^{\circ} \mathrm{C}$, and Jia et al. [442] proposed that $\mathrm{Mg}\left(\mathrm{Ti}_{1-x} \mathrm{Nb}_{x}\right) \mathrm{O}_{3}$ showed microwave dielectric properties: $\varepsilon_{\mathrm{r}} \approx 18.12, Q \times f$ value $\approx$ $163,618 \mathrm{GHz}$, and $\tau_{\mathrm{f}} \approx-40.1 \mathrm{ppm} /{ }^{\circ} \mathrm{C}$. Through sol-gel process, the quality factor of geikielite-type $\mathrm{MgTiO}_{3}$ saturated when the ceramics sintered at $1200{ }^{\circ} \mathrm{C}$ [443]. After adding $\mathrm{B}_{2} \mathrm{O}_{3}$ into $\mathrm{MgTiO}_{3}$, the composite ceramics could be densified at $1100{ }^{\circ} \mathrm{C}$ [444]. Investigation of introduction $\mathrm{SrTiO}_{3}$ into $\mathrm{Mg}\left(\mathrm{Zr}_{0.05} \mathrm{Ti}_{0.95}\right) \mathrm{O}_{3}$ ceramics suggested that a close zero $\tau_{\mathrm{f}}$ value could achieve at $0.96 \mathrm{Mg}\left(\mathrm{Zr}_{0.05} \mathrm{Ti}_{0.95}\right) \mathrm{O}_{3}-0.04 \mathrm{SrTiO}_{3} \quad[445,446]$. In the study of a designed composition of $\mathrm{MgTiO}_{3}(\mathrm{Mg} / \mathrm{Ti}=$
$1,1.02,1.04,1.05,1.07)$, the generation of $\mathrm{MgTi}_{2} \mathrm{O}_{5}$ which derived from $\mathrm{Mg} / \mathrm{Ti}=1$ was restrained, and then pure phase of $\mathrm{MgTiO}_{3}$ was obtained when $\mathrm{Mg} / \mathrm{Ti}=$ 1.02 [447]. $\left(\mathrm{Co}_{1-x} \mathrm{Zn}_{x}\right) \mathrm{TiO}_{3}$ sintered at $1350{ }^{\circ} \mathrm{C}$ possessed $\varepsilon_{\mathrm{r}} \approx 20, Q \times f$ value $\approx 107,000 \mathrm{GHz}$, and $\tau_{\mathrm{f}} \approx-60 \mathrm{ppm} /{ }^{\circ} \mathrm{C}$ with $x=0.05$ [448]. The choice of raw material of $\mathrm{MgO}$ and $\mathrm{Mg}(\mathrm{OH})_{2}$ had a major influence on the phase formation and dielectric loss for $0.97 \mathrm{MgTiO}_{3}-0.03 \mathrm{SrTiO}_{3}$ [449]. In the system of $(1-x) \mathrm{MgTiO}_{3-x} \mathrm{Mg}_{2.05} \mathrm{SiO}_{4.05}$ $0.06 \mathrm{CaTiO}_{3}, \tau_{\mathrm{f}} \approx 1.45 \mathrm{ppm} /{ }^{\circ} \mathrm{C}$ was obtained with $x=$ 0.2 [450]. $\mathrm{ZnTiO}_{3}$-type phase, $\mathrm{Zn}_{2} \mathrm{TiO}_{4}$-type, and $\mathrm{TiO}_{2}$ phase were co-existed in $\left(\mathrm{Zn}_{0.3} \mathrm{Co}_{0.7}\right) \mathrm{Ti}_{1-x} \mathrm{Sn}_{x} \mathrm{O}_{3}$, and the satisfied microwave dielectric properties were $\varepsilon_{\mathrm{r}} \approx$ 24, $Q \times f$ value $\approx 66,700 \mathrm{GHz}$, and $\tau_{\mathrm{f}} \approx-5.43 \mathrm{ppm} /{ }^{\circ} \mathrm{C}$ with $x=0.02$ [451]. It was interesting that $\mathrm{MgTiO}_{3}$ and $\mathrm{Mg}_{2} \mathrm{TiO}_{4}$ were the main phases in $\mathrm{Mg}_{n+1} \mathrm{Ti}_{n} \mathrm{O}_{3 n+1}(n=2$, $3,4,5,6$, and 7), and the $\mathrm{Mg}_{2} \mathrm{TiO}_{4}$ was effectively inhibited with $n$ increasing [452]. New cofired tri-layer ceramic architecture of $\mathrm{MgTiO}_{3} / \mathrm{TiO}_{2} / \mathrm{MgTiO}_{3}$ was designed to realize the temperature-stable and ultrahigh- $Q$ ceramics, where the property comparison of $\mathrm{MgO}-\mathrm{TiO}_{2}$ system (Fig. 20) indicated that this new strategy was effective for developing high-performance dielectric resonators [4]. $2 \mathrm{wt} \% \mathrm{~B}_{2} \mathrm{O}_{3}$ as an addictive could effectively reduce the sintering temperature from 
1275 to $1175{ }^{\circ} \mathrm{C}$ in $0.9625 \mathrm{MgTiO}_{3}-0.0375 \mathrm{Ca}_{0.5} \mathrm{Sr}_{0.5} \mathrm{TiO}_{3}$ [453]. $\mathrm{Mg}_{2} \mathrm{TiO}_{4}$-related and $\mathrm{Mg}_{6} \mathrm{Ti}_{5} \mathrm{O}_{16}$-based ceramics in $\mathrm{MgO}_{-} \mathrm{TiO}_{2}$ system were also reported. $\mathrm{Mg}_{6} \mathrm{Ti}_{5} \mathrm{O}_{16}$-based MWDCs were systematically investigated by $\mathrm{Yu}$ et al. [454], where the $\tau_{\mathrm{f}}$ value could be adjusted to $-3 \mathrm{ppm} /{ }^{\circ} \mathrm{C}$ by $\mathrm{Ca}^{2+}$ substitution. To explore the application for mobile communication, $\mathrm{Nb}^{5+}$ ion was added into $\mathrm{Mg}_{2} \mathrm{SnO}_{4}$ to improve the quality factor [455]. By mechanical synthesis method, the value of quality factor was sensitive to the initial particle size and microstructure of $\mathrm{Mg}_{2} \mathrm{TiO}_{4}$ [456]. Meanwhile, the oxygen vacancies and average sizes were highly influenced on the dielectric loss of adding $\mathrm{La}_{2} \mathrm{O}_{3}, \mathrm{~V}_{2} \mathrm{O}_{5}$, and $\mathrm{CeO}_{2}$ into $\mathrm{Mg}_{2} \mathrm{TiO}_{4}$ [457,458]. A maximum quality factor value of $210,700 \mathrm{GHz}$ was obtained in $\left(\mathrm{Mg}_{1-x} \mathrm{Zn}_{x}\right)_{1.8} \mathrm{Ti}_{1.1} \mathrm{O}_{4}$ with $x=0.06$ [459]. $\left[\left(\mathrm{Mg}_{0.5} \mathrm{Zn}_{0.5}\right)_{0.95} \mathrm{Co}_{0.05}\right]_{2} \mathrm{TiO}_{4}$ was demonstrated as the optimal composition in the solid solution of $(\mathrm{Mg}$, $\mathrm{Zn})_{2} \mathrm{TiO}_{4}-\mathrm{Co}_{2} \mathrm{TiO}_{4}$ with $Q \times f$ value $\approx 2100,000 \mathrm{GHz}$ [460]. The average particle size of pure $\mathrm{Mg}_{2} \mathrm{TiO}_{4}$ nano-powders was reduced to $163 \mathrm{~nm}$ via high energy ball milling method, and the excellent properties were $\varepsilon_{\mathrm{r}} \approx 13.9, Q \times f$ value $\approx 98,600 \mathrm{GHz}$, and $\tau_{\mathrm{f}} \approx$ $-50.9 \mathrm{ppm} /{ }^{\circ} \mathrm{C}$ [461]. Similarly to the formula of $\mathrm{Mg}_{2} \mathrm{TiO}_{4}$, spinel-based $\mathrm{CoZnTiO}_{4}$ ceramics were obtained after sintered at $1200{ }^{\circ} \mathrm{C}$, and the properties were majored by the relative density and grain size [462]. Solid solution of $\mathrm{Mg}_{2}\left(\mathrm{Ti}_{1-x} \mathrm{Sn}_{x}\right) \mathrm{O}_{4}$ [463] and $\mathrm{ZnNiTiO}_{4} / \mathrm{ZnNiTi}_{1-x} \mathrm{Sn}_{x} \mathrm{O}_{4}$ $[464,465]$ was also reported. Until now, the intrinsic dielectric behavior of $\mathrm{Mg}_{2} \mathrm{TiO}_{4}$ based on $\mathrm{P}-\mathrm{V}-\mathrm{L}$ theory and infrared spectra was presented by Li et al. [466], where the $\mathrm{Ti}(1)-\mathrm{O}$ bond plays a primary role in dielectric loss. Meanwhile, $\mathrm{Mg}_{2} \mathrm{Ti}_{1-x} \mathrm{Ga}_{4 x / 3} \mathrm{O}_{4}$ would reach a $Q \times f$ value $\approx 205,416 \mathrm{GHz}$ [467].

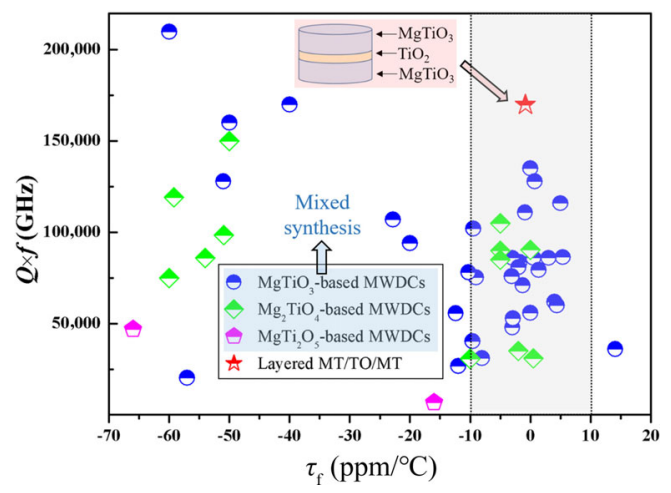

Fig. 20 Summary of $Q \times f$ value versus $\tau_{\mathrm{f}}$ plot for $\mathrm{MgO}-\mathrm{TiO}_{2}$ system MWDCs. Reproduced with permission from Ref. [4], (C) Elsevier Ltd and Techna Group S.r.l. 2018.
Furthermore, there are some compounds in the formula of $\mathrm{Na}_{0.5} \mathrm{Ln}_{0.5} \mathrm{TiO}_{3}(\mathrm{Ln}=\mathrm{Sm}, \mathrm{Nd})$. Fang et al. [468] and Zhou et al. [469] reported a serials of substitution, such as $\mathrm{Na}_{0.5} \mathrm{Nd}_{0.2} \mathrm{Sm}_{0.3} \mathrm{Ti}_{1-x} \mathrm{Sn}_{x} \mathrm{O}_{3}$, $\mathrm{Na}_{0.5} \mathrm{Nd}_{0.5} \mathrm{Ti}_{1-x} \mathrm{Sn}_{x} \mathrm{O}_{3}, \mathrm{Na}_{0.5} \mathrm{Nd}_{0.2} \mathrm{Sm}_{0.3} \mathrm{Ti}_{1-x} \mathrm{Zr}_{x} \mathrm{O}_{3}$ [470], and $\mathrm{Na}_{1 / 2} \mathrm{Sm}_{1 / 2} \mathrm{Ti}_{1-x}\left(\mathrm{Cr}_{1 / 2} \mathrm{Nb}_{1 / 2}\right)_{x} \mathrm{O}_{3}$ [471]. Near zero $\tau_{\mathrm{f}}$ value appeared in $\mathrm{Li}_{0.5} \mathrm{Sm}_{0.5} \mathrm{TiO}_{3}-\mathrm{Na}_{0.5} \mathrm{Sm}_{0.5} \mathrm{TiO}_{3}$ [472].

\subsection{2 $A_{2} B^{\prime} B^{\prime \prime} O_{6}$ formula}

Due to the flexibility and adjustability of the crystal structure of perovskite, the investigation of complex perovskite with various cations occupying $\mathrm{Ti}$ site gradually emerged. The structural studies of $\mathrm{A}_{2} \mathrm{~B}^{\prime} \mathrm{B}^{\prime \prime} \mathrm{O}_{6}$ $\left(\mathrm{A}=\mathrm{Ba}, \mathrm{Sr}, \mathrm{Ca} ; \mathrm{B}^{\prime}=\right.$ lanthanide, $\mathrm{Mg}, \mathrm{Cr}, \mathrm{Bi} ; \mathrm{B}^{\prime \prime}=\mathrm{Nb}$, $\mathrm{Ta}, \mathrm{Sb}, \mathrm{W})$ indicated that phase transitions were ascribed to the tilting of $\mathrm{B}^{\prime} \mathrm{O}_{6} / \mathrm{B}^{\prime \prime} \mathrm{O}_{6}$. In the $\mathrm{Ba}_{2-2 x} \mathrm{Sr}_{2 x} \mathrm{SmSbO}_{6}$ system, phase transitions of $F m \overline{3} m$, $I_{2} / m$, and $P 2_{1} / n$ were observed and the $\tau_{\mathrm{f}}$ value shifted from +25 to $-50 \mathrm{ppm} /{ }^{\circ} \mathrm{C}$ [473]. Effect of nonstoichiometry $\quad \mathrm{Ba}_{1+x}(\mathrm{MgW})_{1 / 2} \mathrm{O}_{3}, \quad \mathrm{Ba}\left(\mathrm{Mg}_{1+y} \mathrm{~W}\right)_{1 / 2} \mathrm{O}_{3}$, and $\mathrm{Ba}\left(\mathrm{MgW}_{1+z}\right)_{1 / 2} \mathrm{O}_{3}$ and the sintering temperature on microwave dielectric properties was systematically investigated by $\mathrm{Wu}$ and Bian [474] and Chen et al. [475], respectively. A zero $\tau_{\mathrm{f}}$ value ceramic was obtained in $\mathrm{Ba}_{2} \mathrm{Mg}_{1-x} \mathrm{Ca}_{x} \mathrm{WO}_{6}$ system with $x=0.1$ [474]. First-principles calculation of assignment for vibrational spectra of $\mathrm{Ba}\left(\mathrm{Mg}_{1 / 2} \mathrm{~W}_{1 / 2}\right) \mathrm{O}_{3}$ MWDCs is shown in Fig. 21 [476], which proposed that $\mathrm{F}_{1 \mathrm{u}}(2)$ modes originated from $\mathrm{Mg}-\mathrm{O}_{6}$ vibrations had the largest contribution to the dielectric properties. The investigation of microwave dielectric properties of giant permittivity ceramics with a $\mathrm{A}_{2} \mathrm{~B}^{\prime} \mathrm{B}^{\prime \prime} \mathrm{O}_{6}$ formula $\left(\mathrm{Ba}\left(\mathrm{Fe}_{1 / 2} \mathrm{Nb}_{1 / 2}\right) \mathrm{O}_{3}\right.$ and $\left.\mathrm{Sr}\left(\mathrm{Fe}_{1 / 2} \mathrm{Nb}_{1 / 2}\right) \mathrm{O}_{3}\right)$ indicated that the permittivity was independent of frequency [477].

$\mathrm{Ln}\left(\mathrm{B}_{0.5} \mathrm{C}_{0.5}\right) \mathrm{O}_{3}(\mathrm{Ln}=\mathrm{La}, \mathrm{Sm}, \mathrm{Nd} ; \mathrm{B}=\mathrm{Mg}, \mathrm{Zn} ; \mathrm{C}=$ $\mathrm{Ti}, \mathrm{Sn}$ ) ceramics belonging to the general formula of $\mathrm{A}_{2} \mathrm{~B}^{\prime} \mathrm{B}^{\prime \prime} \mathrm{O}_{6}$ have been reported as low dielectric loss materials with an adjustable temperature coefficient of resonant frequency. Among them, minor amount of low-melt point oxide of $\mathrm{Bi}_{2} \mathrm{O}_{3}$ and $\mathrm{B}_{2} \mathrm{O}_{3}$ was usually used to enhance the sintering densification of $\mathrm{Sm}\left(\mathrm{Mg}_{0.5} \mathrm{Ti}_{0.5}\right) \mathrm{O}_{3}$ [478,479], $\mathrm{CuO}$ was added into $\mathrm{La}_{2.98 / 3} \mathrm{Sr}_{0.01}\left(\mathrm{Mg}_{0.5} \mathrm{Sn}_{0.5}\right) \mathrm{O}_{3}$ to enhance the densification [480], and $\mathrm{V}_{2} \mathrm{O}_{5}$ was valid for reducing the sintering temperature of $\mathrm{Nd}\left(\mathrm{Zn}_{1 / 2} \mathrm{Ti}_{1 / 2}\right) \mathrm{O}_{3}$ [481]. Solid solution of $\mathrm{Nd}_{(1-x)} \mathrm{Sm}_{x}\left(\mathrm{Mg}_{0.5} \mathrm{Sn}_{0.5}\right) \mathrm{O}_{3}$ [482], $\mathrm{Nd}\left(\mathrm{Mg}_{0.5-x} \mathrm{Co}_{x} \mathrm{Sn}_{0.5}\right) \mathrm{O}_{3}$ [483], $\mathrm{Nd}_{(1-2 x / 3)} \mathrm{Ca}_{x}\left(\mathrm{Mg}_{0.5} \mathrm{Sn}_{0.5}\right) \mathrm{O}_{3}$ [484], $\mathrm{Nd}_{(1-2 x / 3)} \mathrm{Sr}_{x}$ $\left(\mathrm{Mg}_{0.5} \mathrm{Sn}_{0.5}\right) \mathrm{O}_{3}$ [485], $\mathrm{Nd}_{(1-2 x / 3)} \mathrm{Ba}_{x}\left(\mathrm{Mg}_{0.5} \mathrm{Sn}_{0.5}\right) \mathrm{O}_{3}$ [486], 

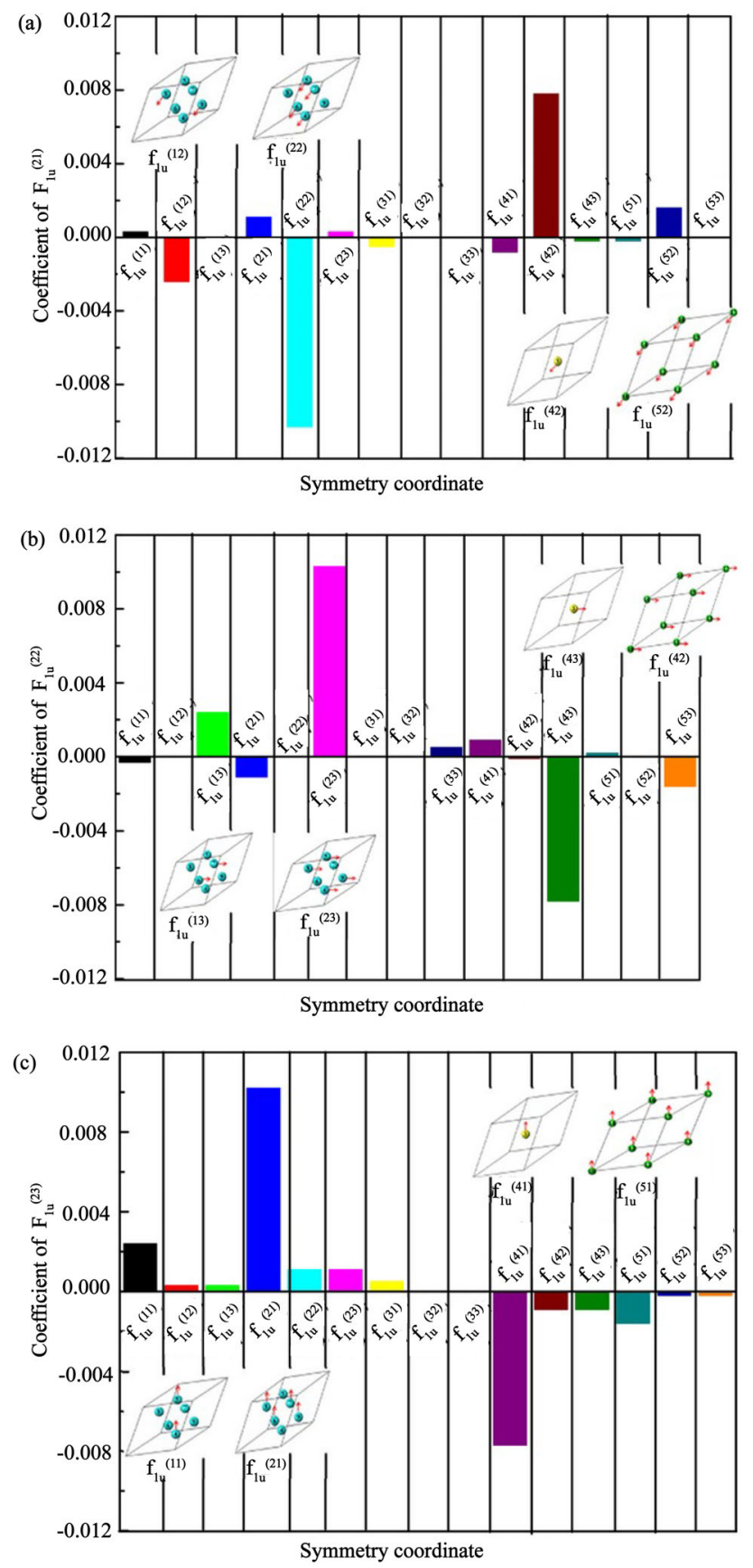

Fig. 21 Combinations of the symmetry coordinates (normalized) for IR-active $\mathrm{F}_{1 \mathrm{u}}(2)$ modes. Reproduced with permission from Ref. [476], (C) The American Ceramic Society 2013.

$\mathrm{Nd}\left(\mathrm{Mg}_{0.5-x} \mathrm{Ni}_{x} \mathrm{Sn}_{0.5}\right) \mathrm{O}_{3}$ [487], $\mathrm{Nd}\left(\mathrm{Mg}_{0.5-x} \mathrm{Zn}_{x} \mathrm{Sn}_{0.5}\right) \mathrm{O}_{3}$ [488], $\mathrm{Nd}\left(\mathrm{Mg}_{0.5} \mathrm{Sn}_{0.5-x} \mathrm{Ti}_{x}\right) \mathrm{O}_{3} \quad$ [489], $\quad \mathrm{Nd}\left(\mathrm{Mg}_{0.5-x} \mathrm{Ca}_{x} \mathrm{Sn}_{0.5}\right) \mathrm{O}_{3}$ [490], $\mathrm{Nd}\left[\left(\mathrm{Zn}_{1-x} \mathrm{Co}_{x}\right)_{0.5} \mathrm{Ti}_{0.5}\right] \mathrm{O}_{3}[491], \mathrm{Nd}\left(\mathrm{Zn}_{0.5+x} \mathrm{Ti}_{0.5}\right) \mathrm{O}_{3}$ [492], $\mathrm{Nd}_{(1+x)}\left(\mathrm{Mg}_{1 / 2} \mathrm{Sn}_{1 / 2}\right) \mathrm{O}_{3}$ [493], $\mathrm{Nd}\left(\mathrm{Mg}_{0.5} \mathrm{Sn}_{0.5(1+x)}\right) \mathrm{O}_{3}$ [494], $\mathrm{La}_{1-x} \mathrm{~B}_{x}\left(\mathrm{Mg}_{0.5} \mathrm{Sn}_{0.5}\right) \mathrm{O}_{3}$ [495], $\quad \mathrm{La}_{(1-x)} \mathrm{Sm}_{x}\left(\mathrm{Mg}_{0.5} \mathrm{Sn}_{0.5}\right) \mathrm{O}_{3}$ [495], $\mathrm{La}_{0.97} \mathrm{Sm}_{0.03}\left(\mathrm{Mg}_{0.5} \mathrm{Sn}_{0.5}\right) \mathrm{O}_{3}-\mathrm{Ca}_{0.8} \mathrm{Sr}_{0.2} \mathrm{TiO}_{3}$ [395], $\mathrm{La}_{1-x} \mathrm{Yb}_{x}\left(\mathrm{Mg}_{0.5} \mathrm{Sn}_{0.5}\right) \mathrm{O}_{3} \quad$ [496], $\quad \mathrm{La}\left(\mathrm{Mg}_{0.5-x} \mathrm{Ba}_{x} \mathrm{Sn}_{0.5}\right) \mathrm{O}_{3}$ [497], $\operatorname{Pr}_{0.22} \mathrm{Y}_{0.78} \mathrm{TiTaO}_{6}$ [498], $\mathrm{La}\left(\mathrm{Mg}_{0.4} \mathrm{Sr}_{0.1} \mathrm{Sn}_{0.5}\right) \mathrm{O}_{3}$
$\mathrm{Nd}\left(\mathrm{Co}_{0.5} \mathrm{Ti}_{0.5}\right) \mathrm{O}_{3}-\mathrm{Ca}_{0.8} \mathrm{Sr}_{0.2} \mathrm{TiO}_{3}[499,500], \mathrm{La}\left(\mathrm{Mg}_{0.5-x} \mathrm{Sr}_{x} \mathrm{Sn}_{0.5}\right) \mathrm{O}_{3}$ [501], $\mathrm{Ca}_{0.6} \mathrm{La}_{0.267} \mathrm{TiO}_{3}-\mathrm{Ca}\left(\mathrm{Sm}_{0.5} \mathrm{Nb}_{0.5}\right) \mathrm{O}_{3}$ [502], and $\mathrm{La}\left[\mathrm{Al}_{1-x}\left(\mathrm{Mg}_{0.5} \mathrm{Ti}_{0.5}\right)_{x}\right] \mathrm{O}_{3}$ [503] was investigated based on sintering behavior and microstructure. Not only the investigations reported the microwave dielectric properties, but also the structure-property relationship containing intrinsic loss, vibrational modes, and chemical bond characteristics of $\mathrm{Y}_{2} \mathrm{MgTiO}_{6}$ was studied in detail, and the schematic representation of vibrational modes of Y site was presented in Fig. 22 [504].

\subsubsection{A $A\left(B_{1 / 3}^{\prime} B_{2 / 3}^{\prime \prime}\right) O_{3}$ formula}

$\mathrm{A}\left(\mathrm{B}_{1 / 3}^{\prime} \mathrm{B}_{2 / 3}^{\prime \prime}\right) \mathrm{O}_{3}\left(\mathrm{~A}=\mathrm{Ba}, \mathrm{Ca} ; \mathrm{B}^{\prime}=\mathrm{Mg}, \mathrm{Zn} ; \mathrm{B}^{\prime \prime}=\mathrm{Nb}, \mathrm{Ta}\right)$ ceramics have been commercially used due to their excellent $Q \times f$ value, and the near-zero $\tau_{\mathrm{f}}$ value. The order structures of $\mathrm{Ca}_{1-0.3 x} \mathrm{La}_{0.2 x}\left[\left(\mathrm{Mg}_{1 / 3} \mathrm{Ta}_{2 / 3}\right)_{1-x} \mathrm{Ti}_{x}\right] \mathrm{O}_{3^{-}}$ based, $\mathrm{Ba}\left(\mathrm{Mg}_{1 / 3} \mathrm{Nb}_{2 / 3}\right) \mathrm{O}_{3}$-based, $\mathrm{Ba}\left(\mathrm{Zn}_{1 / 3} \mathrm{Ta}_{2 / 3}\right) \mathrm{O}_{3}$-based and $\mathrm{Ba}_{3} \mathrm{CaNb}_{2} \mathrm{O}_{9}$ ceramics were investigated by TEM and the vibrational spectra to explain the cation ordering [505-525]. Meanwhile, superstructure reflections were obviously recorded in this system, such as $\mathrm{Ba}\left(\mathrm{Zn}_{1 / 3} \mathrm{Ta}_{2 / 3}\right) \mathrm{O}_{3}$ doped with $\mathrm{Nb}_{2} \mathrm{O}_{5}, \mathrm{MnO}_{2}$, and $\mathrm{V}_{2} \mathrm{O}_{3}$ [526,527]. The wavelength of 1:2 ordered superlattice modulation was about $0.71 \mathrm{~nm}$, while that of disordered superlattice modulation was $0.41 \mathrm{~nm}$ of $\mathrm{Ba}\left(\left(\mathrm{Co}_{0.6-x / 2} \mathrm{Zn}_{0.4-x / 2} \mathrm{Mg}_{x}\right)_{1 / 3} \mathrm{Nb}_{2 / 3}\right) \mathrm{O}_{3}$, shown as Fig. 23 [511]. Adding $\mathrm{MnO}_{2}$ into $\mathrm{Ba}\left(\mathrm{Co}_{1 / 3} \mathrm{Nb}_{2 / 3}\right) \mathrm{O}_{3}$ would enhance the grain growth and restrain the evaporation of $\mathrm{CoO}$ [527]. Meanwhile, the influence of $\mathrm{B}^{\prime \prime}$-site non-stoichiometry of $\mathrm{Ba}\left(\mathrm{Co}_{0.56} \mathrm{Y}_{0.04} \mathrm{Zn}_{0.35}\right)_{1 / 3} \mathrm{Nb}_{2 / 3+x}$ on properties was reported by Tang et al. [528], where $\mathrm{Ba}_{5} \mathrm{Nb}_{4} \mathrm{O}_{15}$ as a secondary phase was recorded. Simulation is carried out for $\mathrm{Ba}\left(\mathrm{Zn}_{1 / 3} \mathrm{Ta}_{2 / 3}\right) \mathrm{O}_{3}$ for the design of linear metal taper [529]. Peng et al. [530] reported that addition of $\mathrm{La}_{2} \mathrm{O}_{3}$ into $\mathrm{Ba}\left(\mathrm{Mg}_{1 / 3} \mathrm{Ta}_{2 / 3}\right) \mathrm{O}_{3}$, $\mathrm{Ba}_{1-x} \mathrm{Ca}_{x}\left(\mathrm{Mg}_{1 / 3} \mathrm{Ta}_{2 / 3}\right) \mathrm{O}_{3}$, and $\mathrm{Ba}\left[\mathrm{Mg}_{1-x} \mathrm{Zn}_{x}\right]_{1 / 3} \mathrm{Ta}_{2 / 3} \mathrm{O}_{3}$ led to the appearance of $\mathrm{Ba}_{0.5} \mathrm{TaO}_{3}$, and $\tau_{\mathrm{f}}$ value reached to near zero [531,532]. The optimal properties of $\mathrm{Ba}\left[\mathrm{Mg}_{(1-x) / 3} \mathrm{Sn}_{x} \mathrm{Ta}_{2(1-x) / 3}\right] \mathrm{O}_{3}$ exhibited as $\varepsilon_{\mathrm{r}} \approx 24.1$, $Q \times f$ value $\approx 138,500 \mathrm{GHz}$, and $\tau_{\mathrm{f}} \approx+0.2 \mathrm{ppm} /{ }^{\circ} \mathrm{C}$ [533]. The variation of $\tau_{\mathrm{f}}$ values for $1: 1$ and 1:2 complex perovskites was clarified to be mainly relevant with tolerance factors, which are summarized in Fig. 24 [524]. It has been verified that samples with non-stoichiometric $\mathrm{Mg}^{2+}$ and $\mathrm{Ta}^{5+}$ in $\mathrm{Ba}\left(\mathrm{Mg}_{1 / 3} \mathrm{Ta}_{2 / 3}\right) \mathrm{O}_{3}$ exhibited a wide temperature stability [525,534], and the correlations between $Q \times f$ versus $\varepsilon_{\mathrm{r}}$ and $\tau_{\mathrm{f}}$ versus $\varepsilon_{\mathrm{r}}$ of high- $Q(\geqslant 100,000 \mathrm{GHz})$ MWDCs are presented in Fig. 25. 

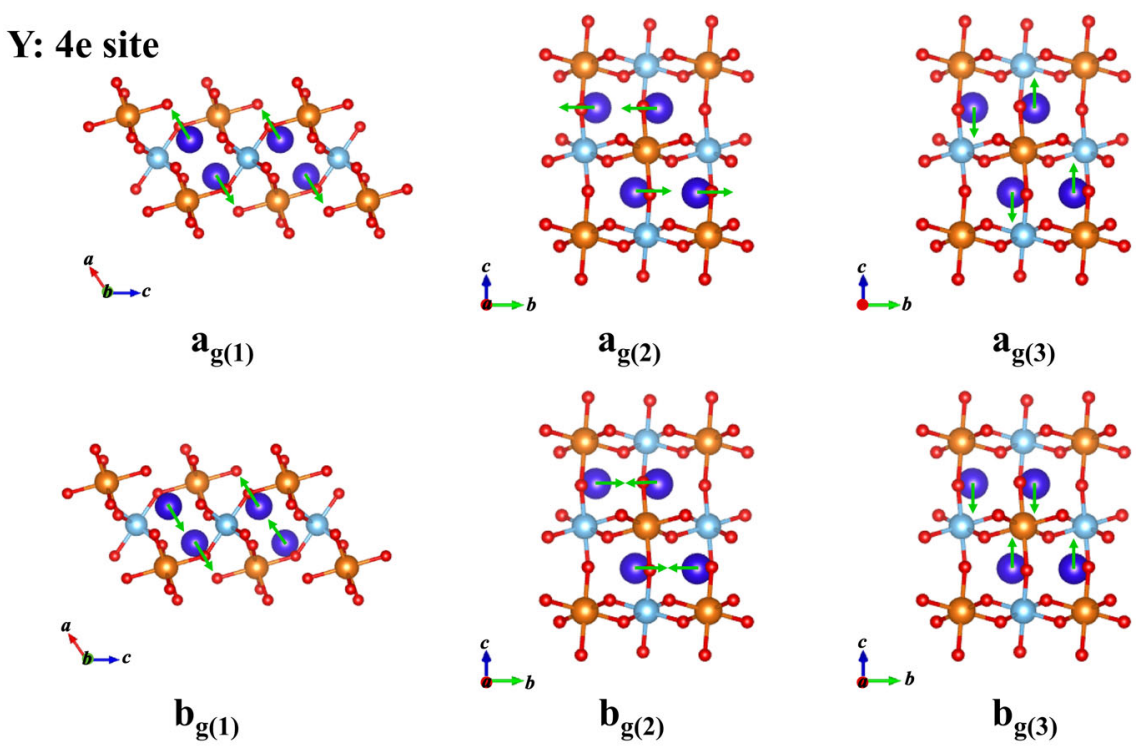

Fig. 22 Schematic representations of the vibrational modes of $\mathrm{Y}_{2} \mathrm{MgTiO}_{6}$ system ( $\mathrm{Y}$ at $4 \mathrm{e}$ site). Reproduced with permission from Ref. [504], (C) The American Ceramic Society 2019.
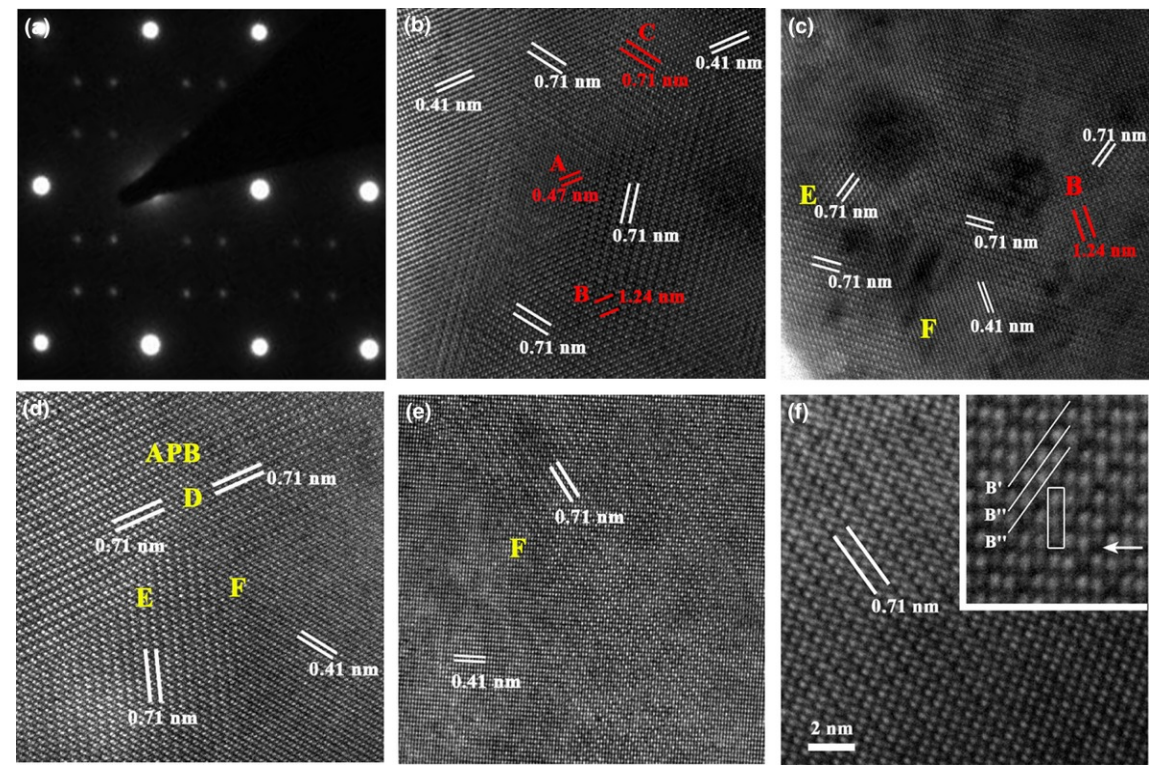

Fig. 23 SAED pattern with zone axis $[1 \overline{1} 0]_{\mathrm{c}}$ and the corresponding HRTEM images for $\mathrm{Ba}\left(\left(\mathrm{Co}_{0.6-x / 2} \mathrm{Zn}_{0.4-x / 2} \mathrm{Mg}_{x}\right)_{1 / 3} \mathrm{Nb}_{2 / 3}\right) \mathrm{O}_{3}$ ceramics: (a) $x=0.1$; (b) $x=0$; (c) $x=0.1$; (d) $x=0.2$; (e) $x=0.3$; (f) HRTEM image of an ordered area in high magnification. Reproduced with permission from Ref. [511], (c) The American Ceramic Society 2013.

\subsection{4 $A_{n} B_{n} O_{3 n+2}$ formula}

Perovskite-related oxides of series $\mathrm{A}_{n} \mathrm{~B}_{n} \mathrm{O}_{3 n+2}=\mathrm{ABO}_{x}$ $(x=3+2 / n)(\mathrm{A}=\mathrm{Ca}, \mathrm{Sr}$, or $\mathrm{La}$ and $\mathrm{B}=\mathrm{Ti}$ or $\mathrm{Nb})$ with $n=4,4.33,4.5,5,6$, and 7 have been a focus owing to their electronic and dielectric properties. The crystal type and the physical properties rely on the value of $n$, which descripts the number of octahedral layers in the slabs [535]. Besides $\mathrm{Ca}_{5} \mathrm{Nb}_{5} \mathrm{O}_{17}$, the $\mathrm{A}_{n} \mathrm{~B}_{n} \mathrm{O}_{3 n+2}$ phases appeared in the binary system of $\mathrm{La}_{2} \mathrm{Ti}_{2} \mathrm{O}_{7}-\mathrm{CaTiO}_{3}$,
$\mathrm{Nd}_{2} \mathrm{Ti}_{2} \mathrm{O}_{7}-\mathrm{CaTiO}_{3}$, and $\mathrm{Ca}_{2} \mathrm{Nb}_{2} \mathrm{O}_{7}-\mathrm{CaTiO}_{3}$. Joseph et al. [536] reported the microwave dielectric properties of $\mathrm{Ca}_{5} \mathrm{~A}_{4} \mathrm{TiO}_{17}(\mathrm{~A}=\mathrm{Nb}, \mathrm{Ta})$ as $\varepsilon_{\mathrm{r}} \approx 44.9, Q \times f$ value $\approx$ $17,600 \mathrm{GHz}$, and $\tau_{\mathrm{f}} \approx-112.9 \mathrm{ppm} /{ }^{\circ} \mathrm{C}$ for $\mathrm{Ca}_{5} \mathrm{Nb}_{4} \mathrm{TiO}_{17}$; $\varepsilon_{\mathrm{r}} \approx 40.1, Q \times f$ value $\approx 16,500 \mathrm{GHz}$, and $\tau_{\mathrm{f}} \approx-53.6$ $\mathrm{ppm} /{ }^{\circ} \mathrm{C}$ for $\mathrm{Ca}_{5} \mathrm{Ta}_{4} \mathrm{TiO}_{17}$. The solid solution of $\mathrm{SrLa}_{4-x} \mathrm{Sm}_{x} \mathrm{Ti}_{5} \mathrm{O}_{17}(0 \leqslant x \leqslant 4)$ and $\mathrm{Sr}_{1-x} \mathrm{Ca}_{x} \mathrm{La}_{4-x} \mathrm{Ti}_{5} \mathrm{O}_{17}$ $(0 \leqslant x \leqslant 1)$ would lower the $\tau_{\mathrm{f}}$ to zero with a dielectric constant of near 53 [537,538], while $\tau_{\mathrm{f}}$ declined to $+70 \mathrm{ppm} /{ }^{\circ} \mathrm{C}$ by $\mathrm{Zr}$ substituted for $\mathrm{Ti}$ of 


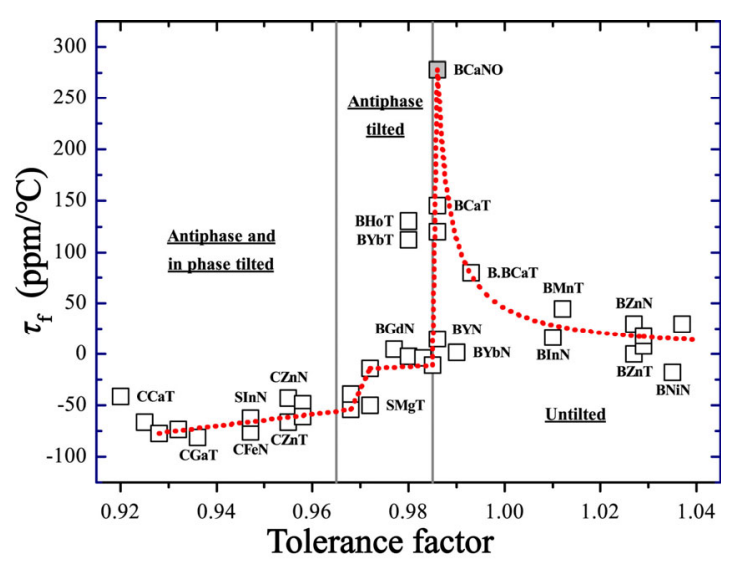

Fig. 24 Temperature coefficient of resonant frequency $\left(\tau_{\mathrm{f}}\right)$ versus tolerance factor $(t)$ for $\mathrm{A}\left(\mathrm{B}^{\prime}, \mathrm{B}^{\prime \prime}\right) \mathrm{O}_{3}(\mathrm{~A}=\mathrm{Ca}, \mathrm{Sr}$, $\mathrm{Ba} ; \mathrm{B}^{\prime}=\mathrm{Mg}, \mathrm{Ca}, \mathrm{Mn}, \mathrm{Fe}, \mathrm{Ni}, \mathrm{Zn}, \mathrm{Ga}, \mathrm{In}, \mathrm{Y}, \mathrm{Gd}, \mathrm{Tb}, \mathrm{Dy}$, $\mathrm{Ho}, \mathrm{Er}, \mathrm{Yb} ; \mathrm{B}^{\prime \prime}=\mathrm{Nb}$, Ta) 1:1 and 1:2 complex perovskites. Reproduced with permission from Ref. [524], C Elsevier Ltd and Techna Group S.r.l. 2016.

$\mathrm{SrLa}_{4} \mathrm{Ti}_{5} \mathrm{O}_{17}$ [539]. The intermediate of two end member phases of $\mathrm{CaLa}_{4} \mathrm{Ti}_{5} \mathrm{O}_{17}$ and $\mathrm{Ca}_{5} \mathrm{Nb}_{4} \mathrm{TiO}_{17}$ showed that the $\varepsilon_{\mathrm{r}}$ varied from 45 to $52, Q \times f$ was in the range of $9870-5680 \mathrm{GHz}$, and $\tau_{\mathrm{f}}$ value ranged between -38 and $-126.4 \mathrm{ppm} /{ }^{\circ} \mathrm{C}$ [540]. $\mathrm{La}_{3} \mathrm{Ti}_{2} \mathrm{TaO}_{11}$ is an member of $n=3$ in this series, and the textured $\mathrm{La}_{3} \mathrm{Ti}_{2} \mathrm{TaO}_{11}$ was fabricated by spark plasma sintering, showing that grain-orientation control was an effective way to tailor the properties of this ceramic [541]. $\mathrm{SrCa}_{4} \mathrm{Nb}_{4} \mathrm{TiO}_{17}$ and $\mathrm{Ca}_{5} \mathrm{Nb}_{4} \mathrm{TiO}_{17}$ sintered at their optimal temperature presented an elongated and plate-like grain [542]. From 0 to 4 , the $\tau_{\mathrm{f}}$ value shifted from -117 to 415 in $\mathrm{NaCa}_{4-x} \mathrm{Sr}_{x} \mathrm{Nb}_{5} \mathrm{O}_{17}$ [543], while the $\tau_{\mathrm{f}}$ value changed in the range of $(-117)-473 \mathrm{ppm} /{ }^{\circ} \mathrm{C}$ for $\mathrm{Na}_{1-x} \mathrm{~K}_{x} \mathrm{Ca}_{4} \mathrm{Nb}_{5} \mathrm{O}_{17}$ [544].

\subsection{5 $\mathrm{Ca}_{4} \mathrm{La}_{2} \mathrm{Ti}_{5} \mathrm{O}_{17}$}

The dielectric properties of $\mathrm{Ca}_{4} \mathrm{La}_{2} \mathrm{Ti}_{5} \mathrm{O}_{17}$ were firstly reported by Rejini et al. [545], which were crystalized as perovskite structure and the XRD results were matched well based on the formula of $\mathrm{Ca}_{0.706} \mathrm{La}_{0.353} \mathrm{Ti}_{0.882} \mathrm{O}_{3}$. There are rare studies about this system, which just concentrated on the modification of $\tau_{\mathrm{f}}$ value. For example, the dielectric constant declined from 71.86 to 35.23 in the solid solution of $\mathrm{Ca}_{4} \mathrm{La}_{2} \mathrm{Ti}_{5-x}\left(\mathrm{Mg}_{1 / 3} \mathrm{Nb}_{2 / 3}\right)_{x} \mathrm{O}_{17}$ $(0 \leqslant x \leqslant 4)$, and a near-zero $\tau_{\mathrm{f}}$ value $\left(1.62 \mathrm{ppm} /{ }^{\circ} \mathrm{C}\right)$ was achieved at $x=3$ [546]. Meanwhile, a near-zero $\tau_{\mathrm{f}}$ value was measured for $0.4 \mathrm{Ca}_{4} \mathrm{La}_{2} \mathrm{Ti}_{5} \mathrm{O}_{17}-0.6 \mathrm{NdAlO}_{3}$ ceramics [547] and $\mathrm{Mg}_{4} \mathrm{La}_{2} \mathrm{Ti}_{5} \mathrm{O}_{17}$ ceramics [548].

\subsection{6 $A_{n} B_{n-1} O_{3 n}$ formula}

A series of $\mathrm{A}_{4} \mathrm{~B}_{3} \mathrm{O}_{12}$-type cation-deficient perovskite ceramics were consistent with the formula of $\mathrm{Sr}_{4-m} \mathrm{La}_{m} \mathrm{Ti}_{m-1} \mathrm{Ta}_{4-m} \mathrm{O}_{12}(m=1,2,3) . \mathrm{Sr}_{3} \mathrm{LaNb}_{3} \mathrm{O}_{12}$ and $\mathrm{SrLa}_{3} \mathrm{Ti}_{2} \mathrm{NbO}_{12}$ were firstly characterized by Fang et al. [549,550]. B-site deficient twinned perovskites such as $\mathrm{Ba}_{8} \mathrm{Ti}_{3} \mathrm{Nb}_{4} \mathrm{O}_{24}, \mathrm{Ba}_{8} \mathrm{MTa}_{6} \mathrm{O}_{24}(\mathrm{M}=\mathrm{Mg}, \mathrm{Zn}, \mathrm{Ni}, \mathrm{Co}, \mathrm{Cu})$, and $\mathrm{Ba}_{8} \mathrm{Ga}_{4-x} \mathrm{Ta}_{4+0.6 x} \mathrm{O}_{24}$ are classified as $\mathrm{A}_{n} \mathrm{~B}_{n-1} \mathrm{O}_{3 n}$
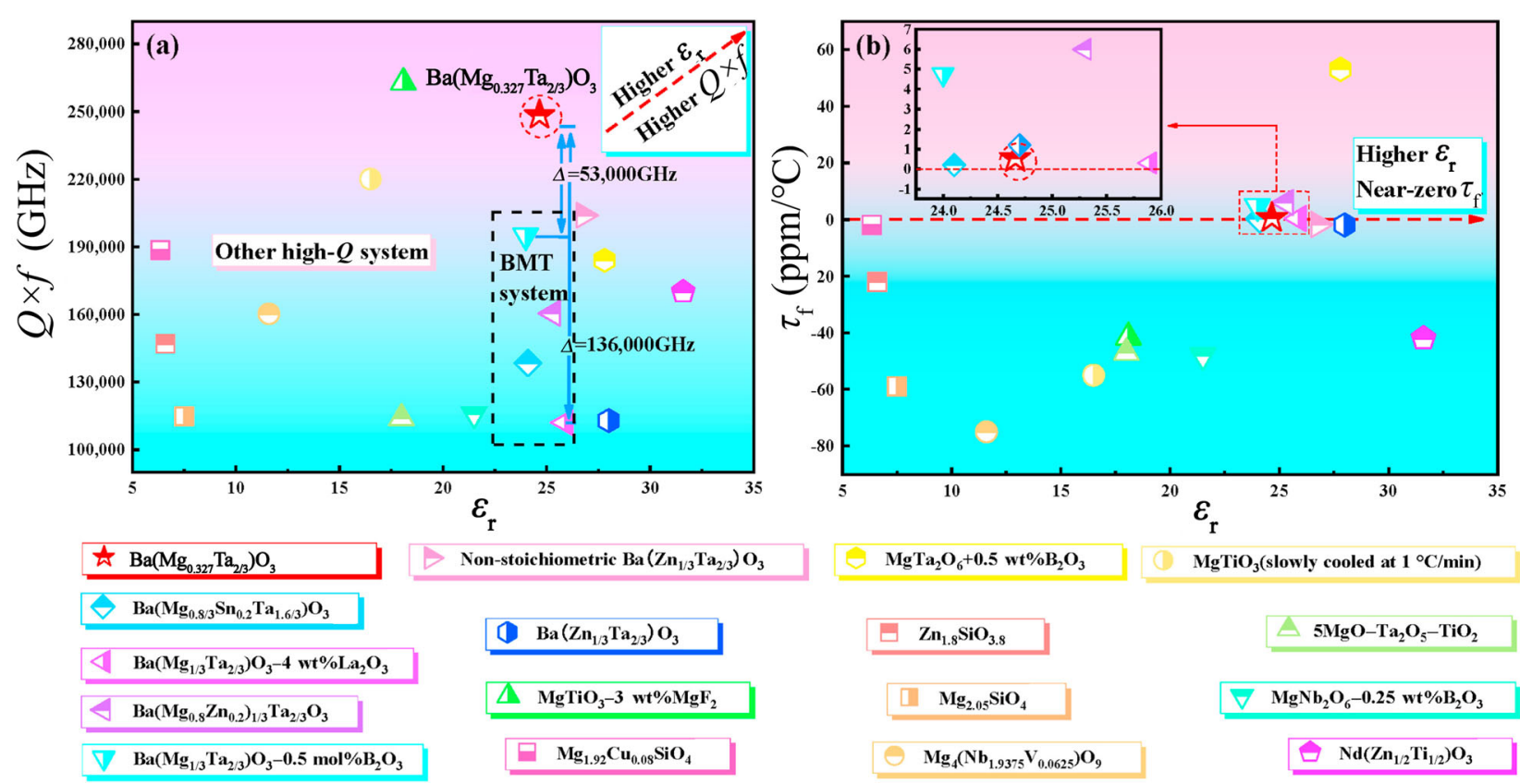

$\mathrm{MgTiO}_{3}$ (slowly cooled at $\left.1^{\circ} \mathrm{C} / \mathrm{min}\right)$

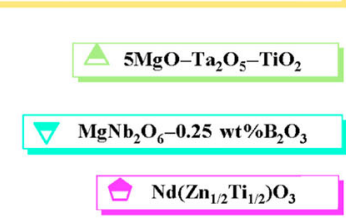

Fig. 25 Correlation between microwave dielectric properties of high- $Q(Q \times f \geqslant 100,000 \mathrm{GHz})$ MWDCs: (a) $Q \times f$ versus $\varepsilon_{\mathrm{r}}$; (b) $\tau_{\mathrm{f}}$ versus $\varepsilon_{\mathrm{r}}$. Reproduced with permission from Ref. [534], C Elsevier Ltd and Techna Group S.r.l. 2020. 
hexagonal perovskites. $\mathrm{Ba}_{8} \mathrm{ZnTa}_{6} \mathrm{O}_{24}$ is a secondary phase of $\mathrm{Ba}\left(\mathrm{Zn}_{1 / 3} \mathrm{Ta}_{2 / 3}\right) \mathrm{O}_{3}$-based systems, and the dielectric properties in the range of $5 \mathrm{~Hz}-50 \mathrm{MHz}$ of $\mathrm{Sb}$ substitution for $\mathrm{Nb}$-site have been systematically studied by Suresh et al. [551,552] through spectroscopic methods. In the microwave frequency region, the $Q \times f$ value and $\tau_{\mathrm{f}}$ values of $\mathrm{Ba}_{8}\left(\mathrm{Mg}_{1-x} \mathrm{Zn}_{x}\right) \mathrm{Ta}_{6} \mathrm{O}_{24}$ ceramics decreased with the augment of $x$ [553]. Similarly, a single phase with hexagonal $8 \mathrm{H}$ perovskite structure of $\mathrm{Ba}_{8} \mathrm{Ti}_{3} \mathrm{Nb}_{4-x} \mathrm{Sb}_{x} \mathrm{O}_{24}$ ceramics was prepared, and $\tau_{\mathrm{f}}$ value declined from 110 to $2 \mathrm{ppm} /{ }^{\circ} \mathrm{C}$ [554]. $\mathrm{BaWO}_{4}$ was used to adjust the large $\tau_{\mathrm{f}}$ value of $8 \mathrm{H}$ hexagonal perovskite $\mathrm{Ba}_{4} \mathrm{LiNb}_{3} \mathrm{O}_{12}$, and the properties of $\varepsilon_{\mathrm{r}} \approx 16.9, Q \times f$ value $\approx 75,500 \mathrm{GHz}$, and $\tau_{\mathrm{f}} \approx+8.7$ $\mathrm{ppm} /{ }^{\circ} \mathrm{C}$ were obtained [555]. Phase transformation in the sequence of hexagonal, hexagonal along with cubic, and cubic was observed in $\mathrm{Ba}_{4} \mathrm{LiNb}_{3-x} \mathrm{Sb}_{x} \mathrm{O}_{12}$ and $\mathrm{Ba}_{4} \mathrm{LiTa}_{3-x} \mathrm{Sb}_{x} \mathrm{O}_{12}$ system. Especially, the optimal microwave dielectric properties were achieved for $\mathrm{Ba}_{4} \mathrm{LiNb}_{2} \mathrm{SbO}_{12}$ with a zero $\tau_{\mathrm{f}}[556,557] . \tau_{\mathrm{f}}$ value dropped from positive to negative in $\mathrm{Ba}_{3} \mathrm{LiTa}_{3-x} \mathrm{Sb}_{x} \mathrm{Ti}_{5} \mathrm{O}_{21}$ [558], and $\mathrm{Ba}_{3} \mathrm{LiNb}_{3-x} \mathrm{Sb}_{x} \mathrm{Ti}_{5} \mathrm{O}_{21}$ [559], while the $\tau_{\mathrm{f}}$ value just reduced from 205 to $70 \mathrm{ppm} /{ }^{\circ} \mathrm{C}$ for $\mathrm{Ba}_{3} \mathrm{LiNb}_{3-x} \mathrm{Ta}_{x} \mathrm{Ti}_{5} \mathrm{O}_{21}$ [560]. A-site deficient perovskite structure was well matched for $\mathrm{LiSmTa}_{4} \mathrm{O}_{12}$ ceramics with tetragonal perovskite structure (A-site deficient perovskite structure), and the optimal microwave dielectric properties were $\varepsilon_{\mathrm{r}} \approx 59.60, Q \times f$ value $\approx 7760 \mathrm{GHz}$, and $\tau_{\mathrm{f}} \approx+41.8 \mathrm{ppm} /{ }^{\circ} \mathrm{C}$ [561].

\subsection{7 $\mathrm{Sr}_{n+1} \mathrm{Ti}_{n} \mathrm{O}_{3 n+1}(n=1,2,34, \infty)$ formula}

Researchers paid their attention to Ruddlesden-Popper (R-P) structure until the dielectric properties of $\mathrm{CaReAlO}_{4}(\mathrm{Re}=\mathrm{Nd}, \mathrm{Sm}, \mathrm{Y})$ were reported. The general formula of R-P compounds was written as
$\left(\mathrm{A}, \mathrm{A}^{\prime}\right)_{n+1} \mathrm{~B}_{n} \mathrm{O}_{3 n+1}$, where the structure was built by corner-sharing $\left(\mathrm{BO}_{6}\right)$ octahedral and interlayer of $\left(\left(\mathrm{A}, \mathrm{A}^{\prime}\right) \mathrm{O}\right) . \mathrm{MLnAlO}_{4}$ and $\mathrm{SrLn}_{2} \mathrm{Al}_{2} \mathrm{O}_{7}(\mathrm{M}=\mathrm{Ca}, \mathrm{Sr}$; $\mathrm{R}=\mathrm{Y}, \mathrm{Sm}, \mathrm{Nd}, \mathrm{La})$ belong to the $\mathrm{R}-\mathrm{P}$ series with $n=1$ and 2, respectively. The crystal structures of $\mathrm{SrLaAlO}_{4}$ and $\mathrm{SrLa}_{2} \mathrm{Al}_{2} \mathrm{O}_{7}$ are presented in Fig. 26. Single crystals of $\mathrm{ABCO}_{4}$ layered compounds with $\mathrm{K}_{2} \mathrm{NiF}_{4}$ structure were used as substrates for high-temperature superconductive thin films, while dielectric properties in this system were mainly investigated by Chen and his co-workers [562-574]. They contributed to analyze the relation between the intrinsic dielectric properties and crystal structure of $\mathrm{MRAlO}_{4}(\mathrm{M}=\mathrm{Ca}, \mathrm{Sr}$; and $\mathrm{R}=$ $\mathrm{Y}, \mathrm{Sm}, \mathrm{Nd}, \mathrm{La})$. Combining the compression/dilation effects of different cation-oxygen bonds and the stability of crystal structure with vibrational spectrum, they emphasized that the drop of the quality factor was ascribed to the abnormal variations of axial bonds and the theoretical dielectric loss was obtained after fitted the infrared reflectivity spectra. With $\left(\mathrm{Zn}_{0.5} \mathrm{Ti}_{0.5}\right)^{3+}$ substituted for $\mathrm{Al}^{3+}$ of $\mathrm{SrLaAlO}_{4}$, the best combination of microwave dielectric properties was $\varepsilon_{\mathrm{r}} \approx 23.5, Q \times f$ value $\approx 102,000 \mathrm{GHz}$, and $\tau_{\mathrm{f}} \approx-3.4 \mathrm{ppm} /{ }^{\circ} \mathrm{C}$ [572]. In the $\mathrm{SrLaAlO}_{4}-\mathrm{Sr}_{2} \mathrm{TiO}_{4}$ system, some diffraction peaks shifted toward higher angles along with the variation of $x$, while some of them shifted toward lower angles, as shown in Fig. 27 [569]. This phenomenon was explained by the opposite change of $a$-axis and $c$-axis, where the octahedron elongated in the $a b$ plane with the shrinkage in the $\mathrm{c}$ direction. The tolerance factor $(t)$ of perovskite layer was used to evaluate the stability of those compounds, and the relation of $t$ and $r\left(\mathrm{M}^{2+}\right) / r\left(\mathrm{Ln}^{3+}\right)$ was plotted in Fig. 28 [573]. $\mathrm{Sr}_{0.6} \mathrm{Ca}_{0.4} \mathrm{LaAlO}_{4}$ with $10 \mathrm{wt} \% \mathrm{TiO}_{2}$ presented a near zero $\tau_{\mathrm{f}} \approx-2.5 \mathrm{ppm} /{ }^{\circ} \mathrm{C}$ [575].

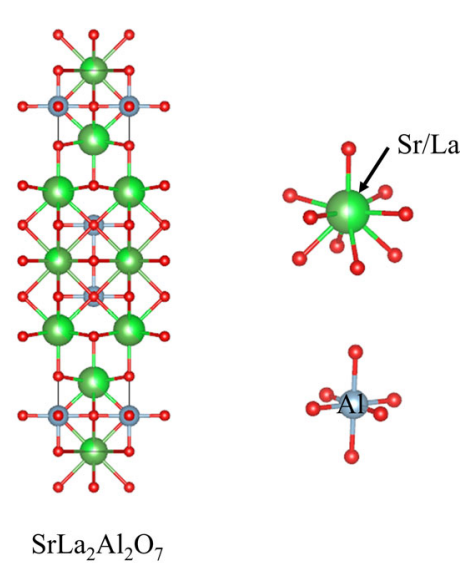

Fig. 26 Crystal structures of $\mathrm{SrLaAlO}_{4}$ and $\mathrm{SrLa}_{2} \mathrm{Al}_{2} \mathrm{O}_{7}$. 

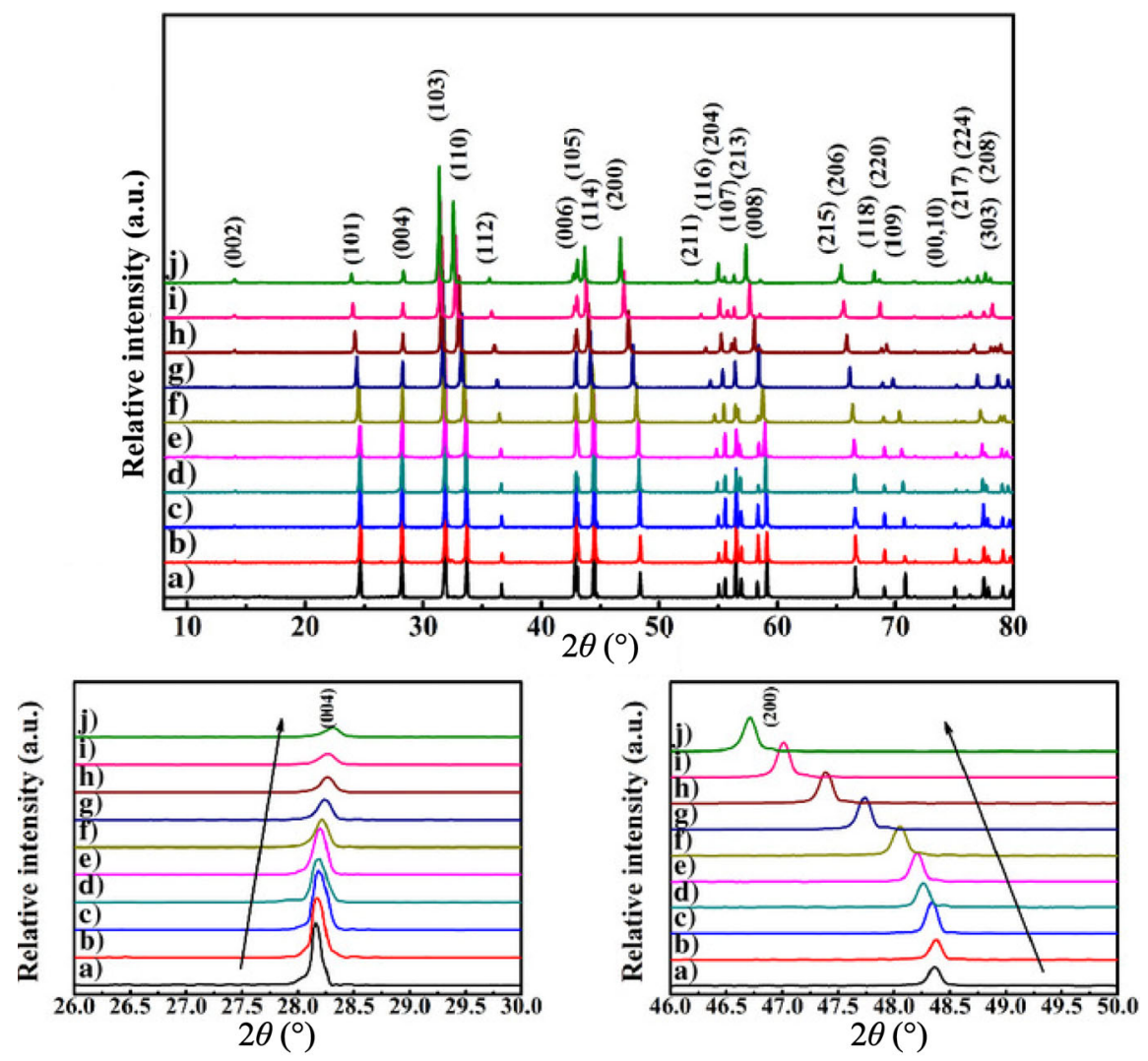

Fig. $27 \mathrm{XRD}$ powder diffraction patterns of ceramics in $(1-x) \mathrm{SrLaAlO}_{4}-x \mathrm{Sr}_{2} \mathrm{TiO}_{4}$ system with enlarged (004) and (200) diffraction peaks: (a) $x=0$, (b) $x=0.025$, (c) $x=0.05$, (d) $x=0.10$, (e) $x=0.15$, (f) $x=0.2$, (g) $x=0.4$, (h) $x=0.6$, (i) $x=0.8$, and (j) $x=1$. Reproduced with permission from Ref. [569], (C) The American Ceramic Society 2011.

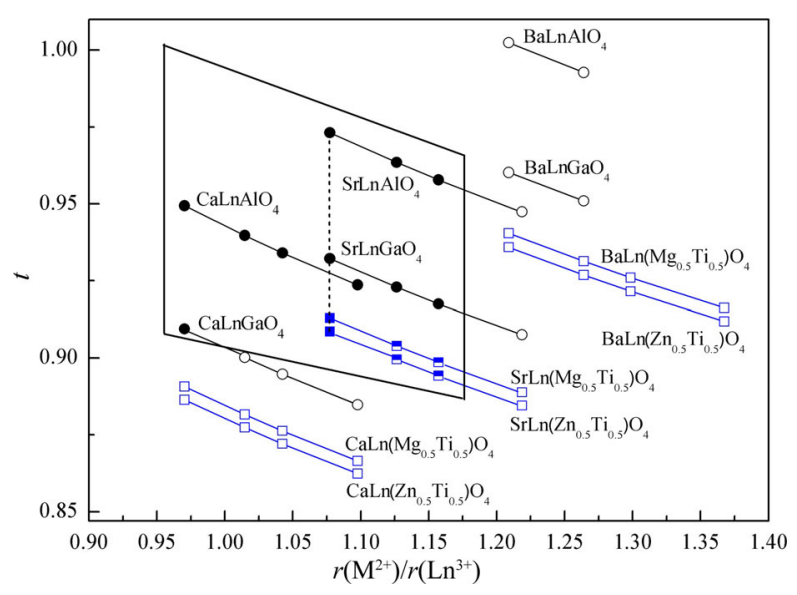

Fig. 28 Stability of $\mathrm{K}_{2} \mathrm{NiF}_{4}$ structure in $\mathrm{MLnBO}_{4}(\mathrm{M}=$ $\mathrm{Ca}, \mathrm{Sr}, \mathrm{Ba} ; \mathrm{Ln}=\mathrm{Y}, \mathrm{Sm}, \mathrm{Nd}, \mathrm{La}$; B = Al, Ga, $\left(\mathrm{Mg}_{0.5} \mathrm{Ti}_{0.5}\right)$, $\left.\left(\mathrm{Zn}_{0.5} \mathrm{Ti}_{0.5}\right)\right)$ compounds in relation to $t$ and $r\left(\mathrm{M}^{2+}\right) / r\left(\mathrm{Ln}^{3+}\right)$. Reproduced with permission from Ref. [573], (C) The American Ceramic Society 2017.

On the other hand, the $\mathrm{R}-\mathrm{P}$ structure such as $\mathrm{Sr}_{n+1} \mathrm{Ti}_{n} \mathrm{O}_{3 n+1}(n=1,2)$ [576], $\mathrm{SrLn}_{2} \mathrm{Al}_{2} \mathrm{O}_{7}(\mathrm{Ln}=\mathrm{La}$, $\mathrm{Nd}, \mathrm{Sm}$ ) [577-581], was also established as $\mathrm{K}_{2} \mathrm{NiF}_{4}$ structure. The interlayer polarization was verified to influence the microstructure and internal stress, and the complete structure information of $\mathrm{SrLn}_{2} \mathrm{Al}_{2} \mathrm{O}_{7}$ ceramics was obtained by TEM. Solid solution of $\left(\mathrm{Sr}_{1-x} \mathrm{Ca}_{x}\right)_{2} \mathrm{TiO}_{4} \quad$ [582], $\quad \mathrm{Sr}_{2} \mathrm{Ti}_{1-x} \mathrm{Sn}_{x} \mathrm{O}_{4} \quad$ [583], $\mathrm{Sr}_{2}$ $\left[\mathrm{Ti}_{1-x}\left(\mathrm{Al}_{0.5} \mathrm{Nb}_{0.5}\right)_{x}\right] \mathrm{O}_{4}$ [584], and $\left(\mathrm{Sr}_{1-3 x / 2} \mathrm{La}_{x}\right)_{2} \mathrm{Ti}_{1-y} \mathrm{Ce}_{y} \mathrm{O}_{4}$ [585] was prepared to reduce the large $\tau_{\mathrm{f}}$ value of $\mathrm{Sr}_{2} \mathrm{TiO}_{4}$. Moreover, $\mathrm{Sr}_{2} \mathrm{CeO}_{4}$ was obtained by Dai and Zuo [586], and the substitution of $\mathrm{Ti}^{4+}$ for $\mathrm{Ce}^{4+}$ in $\mathrm{Sr}_{2} \mathrm{CeO}_{4}$ generated a ceramic with excellent properties of $\varepsilon_{\mathrm{r}} \approx 20.7, Q \times f$ value $\approx 115,550 \mathrm{GHz}$, and $\tau_{\mathrm{f}} \approx$ $-1.8 \mathrm{ppm} /{ }^{\circ} \mathrm{C}$.

\section{6 Other system and machine learning in MWDCs}

Although the pseudo phase diagrams contain various primary systems, some ceramics such as $\mathrm{CeO}_{2}$, $\mathrm{MgAl}_{2} \mathrm{O}_{4}, \mathrm{Ca}_{3} \mathrm{Ln}_{2} \mathrm{~W}_{2} \mathrm{O}_{12}$, and $\mathrm{Ln}_{2} \mathrm{MoO}_{6}(\mathrm{Ln}=\mathrm{La}, \mathrm{Y})$ do not classify. It is difficult to arrange those ceramics to any phase diagram and the relevant reports are relatively less, and thus, the investigations about the mentioned ceramics are listed in this section. $\mathrm{Ce}_{0.75} \mathrm{Y}_{0.25} \mathrm{O}_{1.875}$ ceramic was indexed as $\mathrm{CeO}_{2}$ phase, and the grain size changed from 0.64 to $1.23 \mu \mathrm{m}$ contributing to a higher $Q \times f$ value [587]. The $\tau_{\mathrm{f}}$ value 
of $(1-x) \mathrm{Bi}_{2}\left(\mathrm{Li}_{0.5} \mathrm{Ta}_{1.5}\right) \mathrm{O}_{7}-x \mathrm{TiO}_{2}$ was tuned to $-1.45 \mathrm{ppm} /{ }^{\circ} \mathrm{C}$ with $x=0.04$ [588]. $0.875 \mathrm{CeO}_{2}-0.125 \mathrm{TiO}_{2}$ composition possessed properties of $\varepsilon_{\mathrm{r}} \approx 27.38, Q \times f$ value $\approx$ $12,950 \mathrm{GHz}$, and $\tau_{\mathrm{f}} \approx-2.49 \mathrm{ppm} /{ }^{\circ} \mathrm{C}$, which could meet the criterion of practical application [589]. $\mathrm{MgAl}_{2} \mathrm{O}_{4}$ transparent ceramic was designed and optimal microwave dielectric properties were obtained: $\varepsilon_{\mathrm{r}} \approx 8.2$, $Q \times f$ value $\approx 110,510 \mathrm{GHz}$, and $\tau_{\mathrm{f}} \approx-74.1 \mathrm{ppm} /{ }^{\circ} \mathrm{C}$ [590]. The $\left(\mathrm{Mg}_{0.5} \mathrm{Ti}_{0.4}\right)^{3+}$ for $\mathrm{Al}^{3+}$ in $\mathrm{MgAl}_{2} \mathrm{O}_{4}$ could reduce the sintering temperature approximately $200{ }^{\circ} \mathrm{C}$ due to the less concentration of the Al-O bond [591]. Vibrational spectroscopy and microwave dielectric properties of $\mathrm{Ca}_{3} \mathrm{Ln}_{2} \mathrm{~W}_{2} \mathrm{O}_{12}(\mathrm{Ln}=\mathrm{La}, \mathrm{Sm})$ were analyzed by Liu and Song [592], and the $\varepsilon_{\mathrm{r}}$ of those two phases were 18.7 and 19.5. $\mathrm{Ln}_{2} \mathrm{MoO}_{6}(\mathrm{Ln}=\mathrm{La}, \mathrm{Y})$ ceramics possessed a relative permittivity of 14.1-17.1, and the quality factor was $67,090 \mathrm{GHz}$ for $\mathrm{La}_{2} \mathrm{MoO}_{6}$ and 27,760 GHz for $\mathrm{Y}_{2} \mathrm{MoO}_{6}$, respectively [593].

In the wake of the update of computer science, date-driven approaches including data mining and machine learning have been applied in many disciplines for obtaining the obscure quantitative relationships. For material science, machine learning was used to realize the property prediction, composition optimization, and experimental design [594-600]. Qin et al. [601] employed five commonly-used algorithms with 32 intrinsic chemical, structural, and thermodynamic features for modeling to predict low permittivity materials, where a database of 3300 materials has not been reported and the distribution of permittivity in virtual space of materials was shown in Fig. 29. Quantitative prediction of the $Q \times f$ value of gillespitetype $\mathrm{ACuSi}_{4} \mathrm{O}_{10}(\mathrm{~A}=\mathrm{Ca}, \mathrm{Sr}, \mathrm{Ba})$ ceramics was obtained by machine learning, and the results of $\left(\mathrm{Ca}_{x} \mathrm{Sr}_{1-x}\right) \mathrm{CuSi}_{4} \mathrm{O}_{10}$ and $\left(\mathrm{Ba}_{y} \mathrm{Sr}_{1-y}\right) \mathrm{CuSi}_{4} \mathrm{O}_{10}$ ceramics matched well with the experimental $Q \times f$ value, as shown in Fig. 30 [602].

\section{Conclusions and further outlook}

MWDCs with a suitable permittivity, low dielectric loss, and temperature stability are a perpetual pursuit for researchers. Those ceramics offer technoeconomic advantages including integration, lightweight, and reliability. With the continuous exploration, significant progress is presently being made in designing new compounds, analyzing the polarization mechanism (a)

(b)

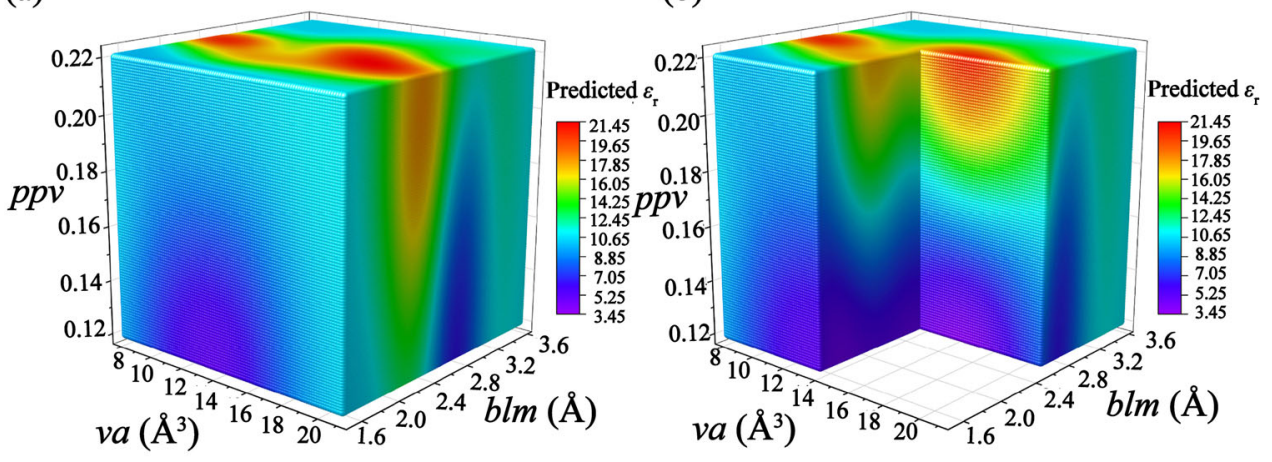

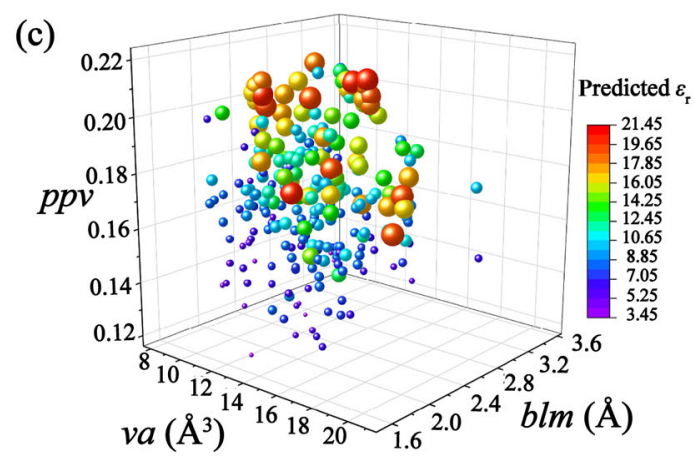

Fig. 29 Distributions of (a) model predicted relative permittivity in virtual space of materials, (b) cross-section of (a) for a clear view of low permittivity zone, and (c) measured permittivity. The notations of $v a, b l m$, and $p p v$ are average cell volume per atom, average bond length, and polarizability per unit volume, respectively. Reproduced with permission from Ref. [601], (C) The Chinese Ceramic Society 2021. 


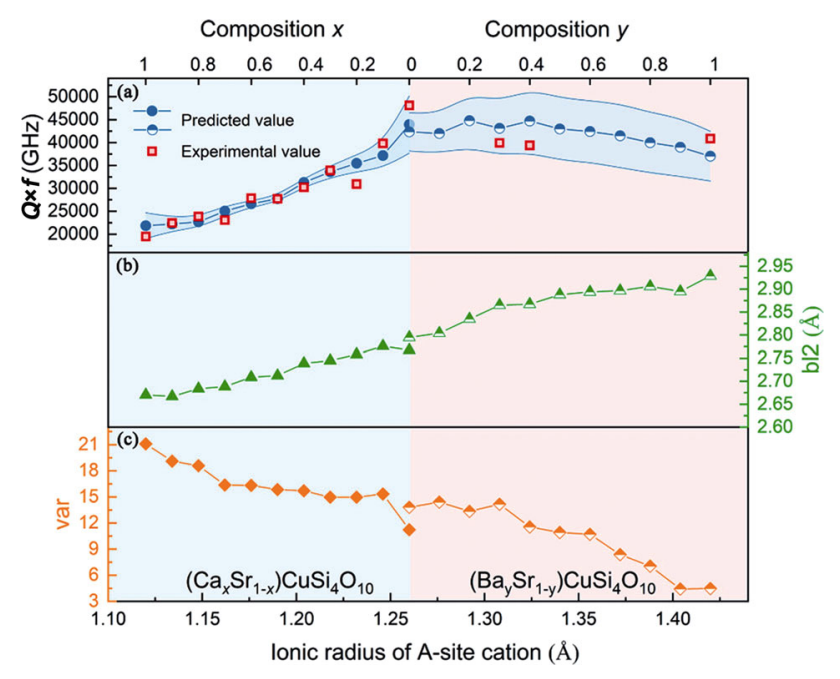

Fig. 30 Machine learning prediction results. (a) Experimental and predicted $Q \times f$ values, (b) feature of bl2 (bond length of $\mathrm{A}-\mathrm{O}_{2}$ bond), and (c) feature of var (variance in bond lengths of $\mathrm{A}-\mathrm{O}$ bond) of $\left(\mathrm{Ca}_{x} \mathrm{Sr}_{1-x}\right) \mathrm{CuSi}_{4} \mathrm{O}_{10}$ and $\left(\mathrm{Ba}_{y} \mathrm{Sr}_{1-y}\right) \mathrm{CuSi}_{4} \mathrm{O}_{10}$ ceramics. The shadow area in (a) represents the standard error of 100 trials. Reproduced with permission from Ref. [602], (C) American Chemical Society 2021.

along with the origin of dielectric loss, and predicting the microwave dielectric properties by theoretical model of machine learning. The relevant computational and experimental methods currently used to probe, predict, and understand intrinsic mechanisms are covered in this review. Because target ceramic system and their associated investigations are so diverse, we provide a brief classification on the composition of ceramics using pseudo phase diagram. The exploration of substitution of the given ceramics or new compounds is listed briefly following the pseudo phase diagram. Experimentally, it appears that substitution and composite ceramics are the most common used methods to optimize the microwave dielectric properties for a given system (reduce dielectric loss or adjust the $\tau_{\mathrm{f}}$ value to near zero). The previous doping researches are concentrated on single ion substitution, while more development of the co-doping (group of two aliovalent cations with a certain mole ratio) appears recently. For the probe of new dielectric materials, the new system usually belongs to germanate and gallate, besides the familiar system of silicate, titanate, niobate, and tantalate. Comparing with conventional solid state reaction method, fabrication techniques containing solution-processed sol-gel method, high energy ball milling method, spark plasma sintering, and microwave sintering have been demonstrated as the promising approaches to improve the properties or sintering behaviors so far. Providing the atmosphere with the volatile element in the sintering procession is a valid method to reduce the pores. Multi-layer ceramic architecture has been verified as a design for temperature-stable ceramics, and the wide application for more system or in the industry is waiting for the exploration.

The influence factor of microwave dielectric properties evolves extrinsic and intrinsic parts. The defects such as porosity, microstructure, and secondary phase are related to the relative density and grain size, which are extrinsic factors. Those results of a unique ceramics can be easily obtained by XRD and SEM, while the investigation of dielectric responded mechanism of intrinsic part is difficult due to the restrain of characterization techniques and the lack of general theory. Theoretically, from Clausius-Mossotti equation, packing fraction, cation valence, distortion of octahedron to the combination of $\mathrm{P}-\mathrm{V}-\mathrm{L}$ theory, lattice dynamics, and $\mathrm{THz}$ time-domain spectroscopy with the first-principles calculation, the intrinsic mechanism for MWDCs is gradually created. Recent efforts to employ $\mathrm{P}-\mathrm{V}-\mathrm{L}$ theory and infrared reflectivity spectra to understanding the intrinsic mechanism seem to be an easy and potential approach to draw conclusions for prediction the microwave dielectric properties. However, the development of "try and error" situation in experiments is a long-term procession. Toward this state end, greater fundamental understanding of dielectric response mechanism and increased practical performance metrics are required. The experimental trials and theoretical calculation serve as a database of MWDCs, and then, the machine learning is applied to predict new materials and their microwave dielectric properties. There has been an emerging trend about machine learning to provide new insight to draw a general conclusion to verify the effect of each factor on the variation of microwave dielectric properties. Challenges remain in the reconciliation of conclusion between existing theoretical approaches, the evaluation of $\mathrm{P}-\mathrm{V}-\mathrm{L}$ theory on microwave dielectric properties, and the advancement of first-principles calculation for describing the state of bond. Based on the theoretical analysis of MWDCs and the careful control of extrinsic influence, more comprehensive applicationspecific analyses to justify their adoption in electronic market may be able to complete.

While there is always a need for fundamental research, 

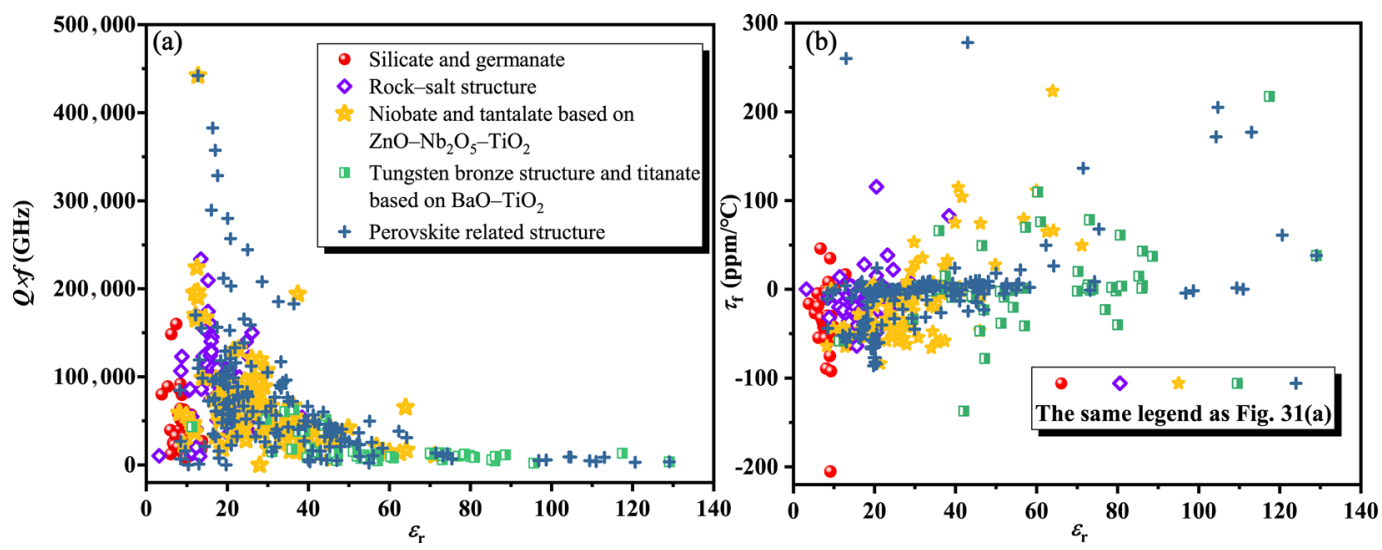

Fig. 31 Microwave dielectric properties of listed references: (a) $\varepsilon_{\mathrm{r}}$ versus $Q \times f$ values and (b) $\varepsilon_{\mathrm{r}}$ versus $\tau_{\mathrm{f}}$ values.

the acceleration of the commercial application of new materials and property optimized ceramics is another persistent target for researchers. This includes ending the limitation of currently available system and exploration materials with stable and excellent properties for electronic market. For example, alternative materials with satisfied microwave dielectric properties equal to perovskite ceramics are required in the industry. With the development of $5 \mathrm{G}$ and $6 \mathrm{G}$, there is an urgent need for ceramics with ultra-low dielectric constant $(<5)$, low dielectric loss, and excellent temperature-stability in high frequencies. The compounds of borate, aluminate, silicate, and fluoride with low polarization should take into consideration as promising candidate. It may be a direction for discovering composite materials consisted of ceramics and organics. Meanwhile, reducing the sintering temperature of ceramics for meeting the need of LTCC is a highly challenging issue owing to its advantages in fabrication of electronic devices. On the other hand, the repeatability of microwave dielectric properties and the normalized evaluation method should be emphasized. The advancement of preparation method with simplified procedures should be taken into consideration as well. The investigation combining the discussion of the performance of a simulated and fabricated device with the analysis of fundamental mechanism of structure-property relationship should be more popularized to provide an entire and systematical exploration. As a summary, the microwave dielectric properties listed in the references are presented in Figs. 31(a) and 31(b).

Lastly, we hope this brief progress report helps to understand the recent experimental methods and suggests an insight to take a new research direction for MWDCs.

\section{Acknowledgements}

This work is supported by the National Natural Science Foundation of China (Grant No. 51872037).

\section{References}

[1] Sebastian M T. Dielectric Materials for Wireless Communication. London, UK: Elsevier, 2008.

[2] Ohsato H, Tsunooka T, Sugiyama T, et al. Forsterite ceramics for millimeterwave dielectrics. $J$ Electroceramics 2006, 17: 445-450.

[3] Zhang J, Luo Y, Yue ZX, et al. High- $Q$ and temperaturestable microwave dielectrics in layer cofired $\mathrm{Zn}_{1.01} \mathrm{Nb}_{2} \mathrm{O}_{6} /$ $\mathrm{TiO}_{2} / \mathrm{Zn}_{1.01} \mathrm{Nb}_{2} \mathrm{O}_{6}$ ceramic architectures. J Am Ceram Soc 2019, 102: 342-350.

[4] Zhang J, Yue ZX, Luo Y, et al. $\mathrm{MgTiO}_{3} / \mathrm{TiO}_{2} / \mathrm{MgTiO}_{3}$ : An ultrahigh- $Q$ and temperature-stable microwave dielectric ceramic through cofired trilayer architecture. Ceram Int 2018, 44: 21000-21003.

[5] Luo WJ, Li LX, Zhang BW, et al. The mechanism of microwave response in layer-cofired $\mathrm{Zn}_{3} \mathrm{Nb}_{2} \mathrm{O}_{8}-\mathrm{TiO}_{2}-$ $\mathrm{Zn}_{3} \mathrm{Nb}_{2} \mathrm{O}_{8}$ ceramic architecture. J Alloys Compd 2020, 824: 153978.

[6] Levine BF. Bond susceptibilities and ionicities in complex crystal structures. J Chem Phys 1973, 59: 1463-1486.

[7] Sebastian MT, Jantunen H. Low loss dielectric materials for LTCC applications: A review. Int Mater Rev 2008, 53: 57-90.

[8] Sebastian MT, Wang H, Jantunen H. Low temperature co-fired ceramics with ultra-low sintering temperature: A review. Curr Opin Solid State Mater Sci 2016, 20: 151170.

[9] Zhou D, Pang LX, Wang DW, et al. $\mathrm{BiVO}_{4}$ based high $k$ microwave dielectric materials: A review. J Mater Chem $C$ 2018, 6: 9290-9313.

[10] Fang Y, Li L, Xiao Q, et al. Preparation and microwave dielectric properties of cristobalite ceramics. Ceram Int 2012, 38: 4511-4515. 
[11] Li F, Liu P, Ruan P, et al. Microwave dielectric properties of $(1-x) \mathrm{SiO}_{2}-x \mathrm{TiO}_{2}$ ceramics. Ceram Int 2015, 41: S582S587.

[12] Sreekanth Chakradhar RP, Nagabhushana BM, Chandrappa GT, et al. Solution combustion derived nanocrystalline macroporous wollastonite ceramics. Mater Chem Phys 2006, 95: 169-175.

[13] Wang HP, Zhang QL, Yang H, et al. Synthesis and microwave dielectric properties of $\mathrm{CaSiO}_{3}$ nanopowder by the sol-gel process. Ceram Int 2008, 34: 1405-1408.

[14] Sun HP, Zhang QL, Yang H, et al. $\left(\mathrm{Ca}_{1-x} \mathrm{Mg}_{x}\right) \mathrm{SiO}_{3}$ : A low-permittivity microwave dielectric ceramic system. Mater Sci Eng: B 2007, 138: 46-50.

[15] Wang HP, Chen JM, Yang WY, et al. Effects of $\mathrm{Al}_{2} \mathrm{O}_{3}$ addition on the sintering behavior and microwave dielectric properties of $\mathrm{CaSiO}_{3}$ ceramics. J Eur Ceram Soc 2012, 32: 541-545.

[16] $\mathrm{Hu} \mathrm{W}$, Liu $\mathrm{HX}$, Hao $\mathrm{H}$, et al. Influence of $\mathrm{Al}_{2} \mathrm{O}_{3}$ addition on the microstructure and microwave dielectric properties of $\alpha-\mathrm{CaSiO}_{3}$ ceramics. J Mater Sci: Mater Electron 2015, 26: 211-216.

[17] Hu W, Liu HX, Hao $\mathrm{H}$, et al. Phase transition, microstructure and microwave dielectric properties of $\alpha-\mathrm{CaSiO}_{3}$ ceramics with $\mathrm{SiO}_{2}$ addition. J Mater Sci: Mater Electron 2015, 26: 1977-1981.

[18] $\mathrm{Hu} \mathrm{W}$, Liu $\mathrm{HX}$, Hao $\mathrm{H}$, et al. Influence of $\mathrm{TiO}_{2}$ additive on the microwave dielectric properties of $\alpha-\mathrm{CaSiO}_{3}-\mathrm{Al}_{2} \mathrm{O}_{3}$ ceramics. Ceram Int 2015, 41: S510-S514.

[19] Ma Q, Wu SP, Jiang C, et al. Microwave dielectric properties of $\mathrm{SnO}_{2}$-doped $\mathrm{CaSiO}_{3}$ ceramics. Ceram Int 2013, 39: 2223-2229.

[20] Joseph T, Sebastian MT. Microwave dielectric properties of alkaline earth orthosilicates $\mathrm{M}_{2} \mathrm{SiO}_{4}(\mathrm{M}=\mathrm{Ba}, \mathrm{Sr}, \mathrm{Ca})$. Mater Lett 2011, 65: 891-893.

[21] Li LX, Wang YC, Xia WS, et al. Effects of $\mathrm{Zn} / \mathrm{Mg}$ ratio on the microstructure and microwave dielectric properties of $\left(\mathrm{Zn}_{1-x} \mathrm{Mg}_{x}\right)_{2} \mathrm{SiO}_{4}$ ceramics. J Electron Mater 2012, 41: 684-688.

[22] Ullah A, Liu HX, Hao H, et al. Phase and microstructure evaluation and microwave dielectric properties of $\mathrm{Mg}_{1-x} \mathrm{Ni}_{x} \mathrm{SiO}_{3}$ ceramics. J Electron Mater 2016, 45: 51335139.

[23] Fu ZF, Ma JL, Liu P, et al. Crystal structure and microwave dielectric properties of middle-temperaturesintered $\mathrm{Mg}_{2} \mathrm{Si}_{1-x} \mathrm{~V}_{x} \mathrm{O}_{4}$ ceramics. J Electroceramics 2016, 36: $82-86$.

[24] Tsunooka T, Androu M, Higashida Y, et al. Effects of $\mathrm{TiO}_{2}$ on sinterability and dielectric properties of high- $Q$ forsterite ceramics. $J$ Eur Ceram Soc 2003, 23: 2573-2578.

[25] Song KX, Chen XM, Fan XC. Effects of Mg/Si ratio on microwave dielectric characteristics of forsterite ceramics. J Am Ceram Soc 2007, 90: 1808-1811.

[26] Liu L, Feng YB, Qiu T, et al. Microstructures and microwave dielectric properties of $\mathrm{Mg}_{2} \mathrm{SiO}_{4}-\mathrm{Ca}_{0.9} \mathrm{Sr}_{0.1} \mathrm{TiO}_{3}$ ceramics. J Mater Sci: Mater Electron 2015, 26: 13161321.

[27] Weng ZZ, Song CX, Xiong ZX, et al. Microstructure and broadband dielectric properties of $\mathrm{Zn}_{2} \mathrm{SiO}_{4}$ ceramics with nano-sized $\mathrm{TiO}_{2}$ addition. Ceram Int 2019, 45: 1325113256.

[28] Lai YM, Zeng YM, Han J, et al. Structure dependence of microwave dielectric properties in $\mathrm{Zn}_{2-x} \mathrm{SiO}_{4-x}-x \mathrm{CuO}$ ceramics. J Eur Ceram Soc 2021, 41: 2602-2609.

[29] Liang Z, Han XN, Wang G, et al. Microwave dielectric properties and sintering behaviors of $\mathrm{Zn}_{1.8} \mathrm{SiO}_{3.8}$ ceramics. J Mater Sci: Mater Electron 2021, 32: 517-523.

[30] Kingon AI, Maria JP, Streiffer SK. Alternative dielectrics to silicon dioxide for memory and logic devices. Nature 2000, 406: 1032-1038.

[31] Wu SP, Jiang C, Mei YX, et al. Synthesis and microwave dielectric properties of $\mathrm{Sm}_{2} \mathrm{SiO}_{5}$ ceramics. $\mathrm{J} \mathrm{Am}$ Ceram Soc 2012, 95: 37-40.

[32] Jiang C, Wu SP, Ma Q, et al. Synthesis and microwave dielectric properties of $\mathrm{Nd}_{2} \mathrm{SiO}_{5}$ ceramics. $J$ Alloys Compd 2012, 544: 141-144.

[33] Lai YM, Su H, Wang G, et al. Improved microwave dielectric properties of $\mathrm{CaMgSi}_{2} \mathrm{O}_{6}$ ceramics through $\mathrm{CuO}$ doping. J Alloys Compd 2019, 772: 40-48.

[34] Xiao M, Wei YS, Zhang P. The effect of sintering temperature on the crystal structure and microwave dielectric properties of $\mathrm{CaCoSi}_{2} \mathrm{O}_{6}$ ceramic. Mater Chem Phys 2019, 225: 99-104.

[35] Cai CY, Chen XQ, Li H, et al. Microwave dielectric properties of $\mathrm{Ca}_{1-x} \mathrm{Sr}_{x} \mathrm{MgSi}_{2} \mathrm{O}_{6}$ ceramics. Ceram Int 2020, 46: 27679-27685.

[36] Chen XQ, Li H, Zhang PC, et al. Phase composition, microstructure, and microwave dielectric properties of $\mathrm{CaMnSi}_{2} \mathrm{O}_{6}$ ceramics. Ceram Int 2021, 47: 4083-4089.

[37] Li CC, Yin CZ, Chen JQ, et al. Crystal structure and dielectric properties of germanate melilites $\mathrm{Ba}_{2} \mathrm{MGe}_{2} \mathrm{O}_{7}$ $(\mathrm{M}=\mathrm{Mg}$ and $\mathrm{Zn}$ ) with low permittivity. J Eur Ceram Soc 2018, 38: 5246-5251.

[38] Manu KM, Karthik C, Ubic R, et al. Effect of $\mathrm{Ca}^{2+}$ substitution on the structure, microstructure, and microwave dielectric properties of $\mathrm{Sr}_{2} \mathrm{Al}_{2} \mathrm{SiO}_{7}$ ceramic. $J$ Am Ceram Soc 2013, 96: 3842-3848.

[39] Manu KM, Joseph T, Sebastian MT. Temperature compensated $\mathrm{Sr}_{2} \mathrm{Al}_{2} \mathrm{SiO}_{7}$ ceramic for microwave applications. Mater Chem Phys 2012, 133: 21-23.

[40] Xiao M, Wei YS, Sun HR, et al. Crystal structure and microwave dielectric properties of low-permittivity $\mathrm{Sr}_{2} \mathrm{MgSi}_{2} \mathrm{O}_{7}$ ceramic. J Mater Sci: Mater Electron 2018, 29: 20339-20346.

[41] Xiao M, Wei YS, Zhang P. The correlations between complex chemical bond theory and microwave dielectric properties of $\mathrm{Ca}_{2} \mathrm{MgSi}_{2} \mathrm{O}_{7}$ ceramics. J Electron Mater 2019, 48: 1652-1659.

[42] Song XQ, Lei W, Xie MQ, et al. Sintering behaviour, lattice energy and microwave dielectric properties of 
melilite-type $\mathrm{BaCo}_{2} \mathrm{Si}_{2} \mathrm{O}_{7}$ ceramics. Mater Res Express 2020, 6: 126322.

[43] Song XQ, Lu WZ, Lou YH, et al. Synthesis, lattice energy and microwave dielectric properties of $\mathrm{BaCu}_{2-x} \mathrm{Co}_{x} \mathrm{Si}_{2} \mathrm{O}_{7}$ ceramics. J Eur Ceram Soc 2020, 40: 3035-3041.

[44] Song XQ, Zou ZY, Lu WZ, et al. Crystal structure, lattice energy and microwave dielectric properties of melilite-type $\mathrm{Ba}_{1-x} \mathrm{Sr}_{x} \mathrm{Cu}_{2} \mathrm{Si}_{2} \mathrm{O}_{7}$ solid solutions. $J$ Alloys Compd 2020, 835: 155340.

[45] Wu SP, Chen DF, Mei YX, et al. Synthesis and microwave dielectric properties of $\mathrm{Ca}_{3} \mathrm{SnSi}_{2} \mathrm{O}_{9}$ ceramics. $J$ Alloys Compd 2012, 521: 8-11.

[46] Bafrooei HB, Liu B, Su WT, et al. $\mathrm{Ca}_{3} \mathrm{MgSi}_{2} \mathrm{O}_{8}$ : Novel low-permittivity microwave dielectric ceramics for $5 \mathrm{G}$ application. Mater Lett 2020, 263: 127248.

[47] Song XQ, Lei W, Wang F, et al. Phase evolution, crystal structure, and microwave dielectric properties of gillespitetype ceramics. J Am Ceram Soc 2021, 104: 1740-1749.

[48] Li C, Ding SH, Zhang Y, et al. Effects of $\mathrm{Ni}^{2+}$ substitution on the crystal structure, bond valence, and microwave dielectric properties of $\mathrm{BaAl}_{2-2 x} \mathrm{Ni}_{2 x} \mathrm{Si}_{2} \mathrm{O}_{8-x}$ ceramics. $J$ Eur Ceram Soc 2021, 41: 2610-2616.

[49] Li C, Ding SH, Song TX, et al. Structure and microwave dielectric properties of $\mathrm{BaAl}_{2-2 x} \mathrm{Li}_{2 x} \mathrm{Si}_{2} \mathrm{O}_{8-2 x}$ ceramics. Ceram Int 2021, 47: 4895-4904.

[50] Felsche J. Rare earth silicates with the apatite structure. $J$ Solid State Chem 1972, 5: 266-275.

[51] Manu KM, Karthik C, Leu LC, et al. Crystal structure and microwave dielectric properties of $\mathrm{LiRE}_{9}\left(\mathrm{SiO}_{4}\right)_{6} \mathrm{O}_{2}$ ceramics $(\mathrm{RE}=\mathrm{La}, \mathrm{Pr}, \mathrm{Nd}, \mathrm{Sm}, \mathrm{Eu}, \mathrm{Gd}$, and $\mathrm{Er}) . \mathrm{J} \mathrm{Am}$ Ceram Soc 2013, 96: 1504-1511.

[52] Thomas S, Sebastian MT. Microwave dielectric properties of $\mathrm{SrRE}_{4} \mathrm{Si}_{3} \mathrm{O}_{13}$ (La, Pr, Nd, Sm, Eu, Gd, Tb, Dy, Er, Tm, Yb, and Y) ceramics. J Am Ceram Soc 2009, 92: 29752981.

[53] Du K, Zou ZY, Song XQ, et al. Correlation between crystal structure and microwave dielectric properties of $\mathrm{CaRE}_{4} \mathrm{Si}_{3} \mathrm{O}_{13}(\mathrm{RE}=\mathrm{La}, \mathrm{Nd}, \mathrm{Sm}$, and Er). J Mater Sci: Mater Electron 2020, 31: 3274-3280.

[54] Ao LY, Tang Y, Li J, et al. Structure characterization and microwave dielectric properties of $\mathrm{LiGa}_{5} \mathrm{O}_{8}$ ceramic with low- $\varepsilon_{\mathrm{r}}$ and low loss. J Eur Ceram Soc 2020, 40: 54985503.

[55] Ao LY, Li J, Tang Y, et al. Structure, far-infrared reflectance spectra, and microwave dielectric properties of $\mathrm{Ba}_{2} \mathrm{MGa}_{11} \mathrm{O}_{20}(\mathrm{M}=\mathrm{Bi}, \mathrm{La})$ ceramics. Ceram Int 2021, 47: 11899-11905.

[56] Li FH, Tang Y, Li J, et al. Effect of A-site cation on crystal structure and microwave dielectric properties of $\mathrm{AGe}_{4} \mathrm{O}_{9}$ $(\mathrm{A}=\mathrm{Ba}, \mathrm{Sr})$ ceramics. J Eur Ceram Soc 2021, 41: 41534159.

[57] Tang Y, Zhang ZW, Li J, et al. $\mathrm{A}_{3} \mathrm{Y}_{2} \mathrm{Ge}_{3} \mathrm{O}_{12}(\mathrm{~A}=\mathrm{Ca}, \mathrm{Mg})$ : Two novel microwave dielectric ceramics with contrasting $\tau_{\mathrm{f}}$ and $Q \times f$. J Eur Ceram Soc 2020, 40: 3989-3995.

[58] Lou WC, Song KX, Hussain F, et al. Bond characteristics and microwave dielectric properties of $\left(\mathrm{Li}_{0.5} \mathrm{Ga}_{0.5}\right)^{2+}$ doped $\mathrm{Mg}_{2} \mathrm{Al}_{4} \mathrm{Si}_{5} \mathrm{O}_{18}$ ceramics. Ceram Int 2020, 46: 2863128638.

[59] Wang Y, Tang Y, Li J, et al. Microwave dielectric properties of silico-carnotite $\mathrm{Ca}_{3} \mathrm{M}_{2} \mathrm{Si}_{3} \mathrm{O}_{12} \quad(\mathrm{M}=\mathrm{Yb}, \mathrm{Y})$ ceramics synthesized via high energy ball milling. Ceram Int 2021, 47: 4831-4837.

[60] Su CX, Fang L, Ao LY, et al. Structure, Raman spectra and microwave dielectric properties of novel garnet-type $\mathrm{Ca}_{3} \mathrm{MZrGe}_{3} \mathrm{O}_{12}(\mathrm{M}=\mathrm{Co}, \mathrm{Zn})$ ceramics. J Asian Ceram Soc 2021, 9: 424-432.

[61] Zhai YF, Tang Y, Li J, et al. Structure, Raman spectra and properties of two low- $\varepsilon$ microwave dielectric ceramics $\mathrm{Ca}_{3} \mathrm{~B}_{2} \mathrm{Ge}_{3} \mathrm{O}_{12}(\mathrm{~B}=\mathrm{Al}, \mathrm{Ga})$. Ceram Int 2020, 46: 28710 28715.

[62] Su CX, Ao LY, Zhai YF, et al. Novel low-permittivity microwave dielectric ceramics in garnet-type $\mathrm{Ca}_{4} \mathrm{ZrGe}_{3} \mathrm{O}_{12}$. Mater Lett 2020, 275: 128149.

[63] Li J, Tang Y, Zhang ZW, et al. Two novel garnet $\mathrm{Sr}_{3} \mathrm{~B}_{2} \mathrm{Ge}_{3} \mathrm{O}_{12}(\mathrm{~B}=\mathrm{Yb}, \mathrm{Ho})$ microwave dielectric ceramics with low permittivity and high Q. J Eur Ceram Soc 2021, 41: 1317-1323.

[64] Tan ZY, Song KX, Bafrooei HB, et al. The effects of $\mathrm{TiO}_{2}$ addition on microwave dielectric properties of $\mathrm{Y}_{3} \mathrm{MgAl}_{3} \mathrm{SiO}_{12}$ ceramic for $5 \mathrm{G}$ application. Ceram Int 2020, 46: 15665-15669.

[65] Yang AH, Tang Y, Li J, et al. Structure and infrared reflectivity spectra of novel $\mathrm{Mg}_{3} \mathrm{Ga}_{2} \mathrm{GeO}_{8}$ microwave dielectric ceramic with high $Q$. Ceram Int 2021, 47: 2450-2455.

[66] Su CX, Ao LY, Zhang ZW, et al. Crystal structure, Raman spectra and microwave dielectric properties of novel temperature-stable $\mathrm{LiYbSiO}_{4}$ ceramics. Ceram Int 2020, 46: 19996-20003.

[67] Du K, Wang F, Song XQ, et al. Correlation between crystal structure and dielectric characteristics of $\mathrm{Ti}^{4+}$ substituted $\mathrm{CaSnSiO}_{5}$ ceramics. J Eur Ceram Soc 2021, 41: 2568-2578.

[68] Du K, Fan J, Zou ZY, et al. Crystal structure, phase compositions, and microwave dielectric properties of malayaite-type $\mathrm{Ca}_{1-x} \mathrm{Sr}_{x} \mathrm{SnSiO}_{5}$ ceramics. J Am Ceram Soc 2020, 103: 6369-6377.

[69] Du K, Song XQ, Zou ZY, et al. Improved microwave dielectric properties of novel low-permittivity Sn-doped $\mathrm{Ca}_{2} \mathrm{HfSi}_{4} \mathrm{O}_{12}$ ceramics. Mater Res Bull 2020, 129: 110887.

[70] Templeton A, Wang XR, Penn SJ, et al. Microwave dielectric loss of titanium oxide. J Am Ceram Soc 2000, 83: 95-100.

[71] Kim ES, Kang DH. Relationships between crystal structure and microwave dielectric properties of $\left(\mathrm{Zn}_{1 / 3} \mathrm{~B}_{2 / 3}{ }^{5+}\right)_{x} \mathrm{Ti}-x \mathrm{O}_{2}\left(\mathrm{~B}^{5+}=\mathrm{Nb}, \mathrm{Ta}\right)$ ceramics. Ceram Int 2008, 34: 883-888.

[72] Baumgarte A, Blachnik R. Phase relations in the system titaniumdioxide-diniobium-zinc-hexoxide. Mater Res Bull 1992, 27: 1287-1294. 
[73] Yang HY, Zhang SR, Yang HC, et al. Usage of P-V-L bond theory in studying the structural/property regulation of microwave dielectric ceramics: A review. Inorg Chem Front 2020, 7: 4711-4753.

[74] Liao QW, Li LX, Ding X, et al. A new temperature stable microwave dielectric material $\mathrm{Mg}_{0.5} \mathrm{Zn}_{0.5} \mathrm{TiNb}_{2} \mathrm{O}_{8} . \mathrm{J} \mathrm{Am}$ Ceram Soc 2012, 95: 1501-1503.

[75] Yang HY, Li EZ, Duan SX, et al. Structure, microwave properties and low temperature sintering of $\mathrm{Ta}_{2} \mathrm{O}_{5}$ and $\mathrm{Co}_{2} \mathrm{O}_{3}$ codoped $\mathrm{Zn}_{0.5} \mathrm{Ti}_{0.5} \mathrm{NbO}_{4}$ ceramics. Mater Chem Phys 2017, 199: 43-53.

[76] Li LX, Cai HC, Yu XX, et al. Structure analysis and microwave dielectric properties of $\mathrm{Ca}_{x} \mathrm{Zn}_{1-x} \mathrm{Sn}_{0.08} \mathrm{Ti}_{1.92} \mathrm{Nb}_{2} \mathrm{O}_{10}$ ceramics. J Alloys Compd 2014, 584: 315-321.

[77] Yang HY, Zhang SR, Yang HC, et al. Structural evolution and microwave dielectric properties of $x \mathrm{Zn}_{0.5} \mathrm{Ti}_{0.5} \mathrm{NbO}_{4}^{-}$ $(1-x) \mathrm{Zn}_{0.15} \mathrm{Nb}_{0.3} \mathrm{Ti}_{0.55} \mathrm{O}_{2}$ ceramics. Inorg Chem 2018, 57: 8264-8275.

[78] Yang HY, Zhang SR, Yang HC, et al. Effects of $\mathrm{ZrO}_{2}$ substitution on crystal structure and microwave dielectric properties of $\mathrm{Zn}_{0.15} \mathrm{Nb}_{0.3}\left(\mathrm{Ti}_{1-x} \mathrm{Zr}_{x}\right)_{0.55} \mathrm{O}_{2}$ ceramics. Ceram Int 2018, 44: 22710-22717.

[79] Chen YW, Zhang SR, Yang HY, et al. Bond ionicity, lattice energy and structural evolution of $\mathrm{Ta}$ substituted $0.15 \mathrm{ZnO}-0.15 \mathrm{Nb}_{2} \mathrm{O}_{5}-0.55 \mathrm{TiO}_{2}$ dielectric ceramics. Ceram Int 2019, 45: 8832-8839.

[80] Ramarao SD, Murthy VRK. Crystal structure refinement and microwave dielectric properties of new low dielectric loss $\mathrm{AZrNb}_{2} \mathrm{O}_{8}$ (A: Mn, Zn, Mg and Co) ceramics. Scripta Mater 2013, 69: 274-277.

[81] Jiang XS, Pan HL, Feng ZB, et al. Characterization of microwave dielectric materials $\mathrm{NiZrNb}_{2} \mathrm{O}_{8}$ based on the chemical bond theory. J Mater Sci: Mater Electron 2016, 27: 10963-10969.

[82] Pan HL, Feng ZB, Bi JX, et al. Preparation, characterization, and dielectric properties of wolframitestructure $\mathrm{MnZrNb}_{2} \mathrm{O}_{8}$ ceramics at microwave frequency. $J$ Alloys Compd 2015, 651: 440-444.

[83] Xia WS, Yang FY, Zhang GY, et al. New low-dielectricloss $\mathrm{NiZrNb}_{2} \mathrm{O}_{8}$ ceramics for microwave application. $J$ Alloys Compd 2016, 656: 470-475.

[84] Wu HT, Bi JX, Wang HJ, et al. Sintering characteristics and microwave dielectric properties of low loss $\mathrm{ZnZrNb}_{2} \mathrm{O}_{8}$ ceramics achieved by reaction sintering process. J Mater Sci: Mater Electron 2016, 27: 56705675.

[85] Wu HT, Feng ZB, Mei QJ, et al. Correlations of crystal structure, bond energy and microwave dielectric properties of $\mathrm{AZrNb}_{2} \mathrm{O}_{8}(\mathrm{~A}=\mathrm{Zn}, \mathrm{Co}, \mathrm{Mg}, \mathrm{Mn})$ ceramics. $J$ Alloys Compd 2015, 648: 368-373.

[86] Cheng Y, Zuo RZ, Lv Y. Preparation and microwave dielectric properties of low-loss $\mathrm{MgZrNb}_{2} \mathrm{O}_{8}$ ceramics. Ceram Int 2013, 39: 8681-8685.

[87] Yang HY, Zhang SR, Li YP, et al. Investigations of dielectric properties of wolframite $\mathrm{A}_{0.5} \mathrm{Zr}_{0.5} \mathrm{NbO}_{4}$ ceramics by bond theory and far-infrared spectroscopy. Ceram Int 2020, 46: 3688-3694.

[88] Wu HT, Kim ES. Characterization of crystal structure and microwave dielectric properties of $\mathrm{AZrNb}_{2} \mathrm{O}_{8}(\mathrm{~A}=\mathrm{Zn}, \mathrm{Co}$, $\mathrm{Mg}, \mathrm{Mn}$ ) ceramics based on complex bond theory. Ceram Int 2016, 42: 5785-5791.

[89] Zhang Y, Ding SH, Li C, et al. Bond analysis of novel $\mathrm{MnZrTa}_{2} \mathrm{O}_{8}$ microwave dielectric ceramics with monoclinic structure. J Mater Sci 2020, 55: 8491-8501.

[90] Yang HY, Zhang SR, Yang HC, et al. Structure, phase composition, Raman spectra, and microwave dielectric properties of novel $\mathrm{Co}_{0.5} \mathrm{Zr}_{0.5} \mathrm{TaO}_{4}$ ceramics. Ceram Int 2019, 45: 15445-15450.

[91] Xia WS, Zhang LY, Wang Y, et al. Extrinsic effects on microwave dielectric properties of high- $Q \quad \mathrm{MgZrTa}_{2} \mathrm{O}_{8}$ ceramics. J Mater Sci: Mater Electron 2016, 27: 1132511330 .

[92] Cai HC, Li LX, Sun H, et al. A microwave dielectric material $\mathrm{Mg}_{0.5} \mathrm{Zn}_{0.5} \mathrm{ZrNb}_{2} \mathrm{O}_{8}$. Mater Lett 2015, 144: 78-81.

[93] Ye J, Li LX, Sun H, et al. Microstructure and microwave dielectric characteristics of $\left(\mathrm{Zn}_{1-x} \mathrm{Co}_{x}\right) \mathrm{ZrNb}_{2} \mathrm{O}_{8}$ ceramics. J Mater Sci: Mater Electron 2015, 26: 8954-8959.

[94] Yang ZL, Pan HL, Jiang XS, et al. Characterization of low loss microwave dielectric materials $\mathrm{Zn}_{0.92} \mathrm{Co}_{0.08} \mathrm{ZrNb}_{2} \mathrm{O}_{8}$ based on the complex chemical bond theory. J Mater Sci: Mater Electron 2017, 28: 1597-1604.

[95] Pan HL, Liu QQ, Zhang YH, et al. Crystal structure and microwave dielectric characteristics of Co-substituted $\mathrm{Zn}_{1-x} \mathrm{Co}_{x} \mathrm{ZrNb}_{2} \mathrm{O}_{8}(0 \leqslant x \leqslant 0.1)$ ceramics. RSC Adv 2016, 6: 86889-86903.

[96] Wang SY, Xiao BY, Li JY, et al. Structural evolution, Raman spectra, and microwave dielectric properties of Zr-substituted $\mathrm{ZnTiTa}_{2} \mathrm{O}_{8}$ ceramics. J Mater Sci: Mater Electron 2020, 31: 10298-10305.

[97] Li LX, Zhang S, Ye J, et al. Crystal structure and microwave dielectric properties of the low dielectric loss $\mathrm{ZnZr}_{1-x} \mathrm{Sn}_{x} \mathrm{Nb}_{2} \mathrm{O}_{8}$ ceramics. Ceram Int 2016, 42: $9157-$ 9161.

[98] Ye J, Li LX, Li S, et al. A new microwave dielectric material $\mathrm{ZnZr}_{0.8} \mathrm{Sn}_{0.2} \mathrm{Nb}_{2} \mathrm{O}_{8}$. J Mater Sci: Mater Electron 2016, 27: 97-102.

[99] Xiao M, He SS, Lou J, et al. Structure and microwave dielectric properties of $\mathrm{MgZr}\left(\mathrm{Nb}_{1-x} \mathrm{Sb}_{x}\right)_{2} \mathrm{O}_{8}(0 \leq x \leq 0.1)$ ceramics. J Alloys Compd 2019, 777: 350-357.

[100] Zhao YG, Zhang P. A novel low loss microwave dielectric ceramic $\mathrm{ZnZrNb}_{1.84} \mathrm{Sb}_{0.16} \mathrm{O}_{8}$ with wolframite structure. $J$ Mater Sci: Mater Electron 2016, 27: 2933-2937.

[101] Li LX, Sun H, Lv X, et al. A new microwave dielectric material $\mathrm{ZnZrNbTaO}_{8}$. Mater Lett 2015, 160: 363-365.

[102] Xiao M, He SS, Meng J, et al. Dependence of microwave dielectric properties on the substitution of isovalent composite ion for $\mathrm{Nb}$-site of $\mathrm{MgZrNb}_{2-x}\left(\mathrm{Sn}_{1 / 2} \mathrm{~W}_{1 / 2}\right)_{x} \mathrm{O}_{8}$ $(0 \leqslant x \leqslant 0.15)$ ceramics. J Mater Sci: Mater Electron 2019, 30: 18280-18286.

[103] Xiao M, He SS, Meng J, et al. Bond ionicity, lattice energy, 
bond energy and the microwave dielectric properties of non-stoichiometric $\mathrm{MgZrNb}_{2+x} \mathrm{O}_{8+2.5 x}$ ceramics. Mater Chem Phys 2020, 242: 122412.

[104] Zhang J, Zuo RZ, Cheng Y. Relationship of the structural phase transition and microwave dielectric properties in $\mathrm{MgZrNb}_{2} \mathrm{O}_{8}-\mathrm{TiO}_{2}$ ceramics. Ceram Int 2016, 42: 76817689.

[105] Lyu XS, Li LX, Zhang S, et al. Crystal structure and microwave dielectric properties of novel $(1-x) \mathrm{ZnZrNb}_{2} \mathrm{O}_{8}-x \mathrm{TiO}_{2}$ ceramics. Mater Lett 2016, 171: $129-132$.

[106] Wu HT, Guo JD, Bi JX, et al. Effect of $\mathrm{H}_{3} \mathrm{BO}_{3}$ addition on the sintering behavior and microwave dielectric properties of wolframite-type $\mathrm{MgZrNb}_{2} \mathrm{O}_{8}$ ceramics. $J$ Alloys Compd 2016, 661: 535-540.

[107] Wu HT, Mei QJ, Xing CF, et al. Effects of $\mathrm{B}_{2} \mathrm{O}_{3}$ addition on sintering behavior and microwave dielectric properties of ixiolite-structure $\mathrm{ZnTiNb}_{2} \mathrm{O}_{8}$ ceramics. $J$ Alloys Compd 2016, 679: 26-31.

[108] Bi JX, Xing CF, Jiang XS, et al. Effect of $\mathrm{H}_{3} \mathrm{BO}_{3}$ on sintering behavior and microwave dielectric properties of monoclinal structure $\mathrm{ZnZrNb}_{2} \mathrm{O}_{8}$ ceramics. J Mater Sci: Mater Electron 2016, 27: 8055-8061.

[109] Liao QW, Li LX, Ren X, et al. A new microwave dielectric material $\mathrm{Ni}_{0.5} \mathrm{Ti}_{0.5} \mathrm{NbO}_{4}$. Mater Lett 2012, 89: 351-353.

[110] Tseng CF. Microwave dielectric properties of a new $\mathrm{Cu}_{0.5} \mathrm{Ti}_{0.5} \mathrm{NbO}_{4}$ ceramics. J Eur Ceram Soc 2015, 35: 383-387.

[111] Tseng CF. Microwave dielectric properties of low loss microwave dielectric ceramics: $\mathrm{A}_{0.5} \mathrm{Ti}_{0.5} \mathrm{NbO}_{4}(\mathrm{~A}=\mathrm{Zn}$, Co). J Eur Ceram Soc 2014, 34: 3641-3648.

[112] Zhang Y, Zhang YC. Microwave dielectric properties of sol-gel derived $\mathrm{CoTiNb}_{2} \mathrm{O}_{8}$ ceramics. J Alloys Compd 2016, 683: 86-91.

[113] Chen TK, Ma WB, Sun QC, et al. The microwave dielectric properties of $(\mathrm{Ni}, \mathrm{Zn})_{0.5} \mathrm{Ti}_{0.5} \mathrm{NbO}_{4}$ solid solution. Mater Lett 2013, 113: 111-113.

[114] Zhang Y, Zhang YC, Xiang MQ. Microwave dielectric properties of temperature stable $\mathrm{CoTiNb}_{2} \mathrm{O}_{8}-\mathrm{CoNb}_{2} \mathrm{O}_{6}$ composite ceramics. Mater Lett 2016, 178: 175-177.

[115] Zhang Y, Ding SH, You L, et al. Temperature stable microwave dielectric ceramic $\mathrm{CoTiNb}_{2} \mathrm{O}_{8}-\mathrm{Zn}_{1.01} \mathrm{Nb}_{2} \mathrm{O}_{6}$ with ultra-low dielectric loss. J Electron Mater 2019, 48: 867-872.

[116] Zhang Y, Zhang YC, Xiang MQ. Crystal structure and microwave dielectric characteristics of $\mathrm{Zr}$-substituted $\mathrm{CoTiNb}_{2} \mathrm{O}_{8}$ ceramics. J Eur Ceram Soc 2016, 36: 1945-1951.

[117] Li YY, Lu XC, Zhang Y, et al. Characterization of $\mathrm{Co}_{0.5}\left(\mathrm{Ti}_{1-x} \mathrm{Zr}_{x}\right)_{0.5} \mathrm{NbO}_{4}$ microwave dielectric ceramics based on structural refinement. Ceram Int 2017, 43: 11516-11522.

[118] Wang J, Lu XC, Li YY, et al. Correlations between microwave dielectric properties and crystal structures of Sb-doped $\mathrm{Co}_{0.5} \mathrm{Ti}_{0.5} \mathrm{NbO}_{4}$ ceramics. Ceram Int 2020, 46:
3464-3470.

[119] Kremer RK, Greedan JE. Magnetic ordering in $\mathrm{CoTa}_{2} \mathrm{O}_{6}$ and $\mathrm{NiTa}_{2} \mathrm{O}_{6}$. J Solid State Chem 1988, 73: 579-582.

[120] Reimers JN, Greedan JE, Stager CV, et al. Crystal structure and magnetism in $\mathrm{CoSb}_{2} \mathrm{O}_{6}$ and $\mathrm{CoTa}_{2} \mathrm{O}_{6}$. J Solid State Chem 1989, 83: 20-30.

[121] Yang HY, Zhang SR, Chen YW, et al. Crystal chemistry, Raman spectra, and bond characteristics of trirutile-type $\mathrm{Co}_{0.5} \mathrm{Ti}_{0.5} \mathrm{TaO}_{4}$ microwave dielectric ceramics. Inorg Chem 2019, 58: 968-976.

[122] Kumada N, Koike N, Nakanome K, et al. Synthesis of rutile-type solid solution $\mathrm{Ni}_{1-x} \mathrm{Co}_{x} \mathrm{Ti}\left(\mathrm{Nb}_{1-y} \mathrm{Ta}_{y}\right)_{2} \mathrm{O}_{8}(0 \leqslant$ $x \leqslant 1,0 \leqslant y \leqslant 1)$ and its optical property. $J$ Asian Ceram Soc 2017, 5: 284-289.

[123] Li EZ, Wen QY, Yang HC, et al. Novel temperature stable $\mathrm{NiSnTa}_{2} \mathrm{O}_{8}$ microwave dielectric ceramics with trirutile structure. Ceram Int 2020, 46: 6079-6084.

[124] Baumgarte A, Blachnik R. Isothermal sections in the systems $\mathrm{ZnO}-\mathrm{AO}_{2}-\mathrm{Nb}_{2} \mathrm{O}_{5}(\mathrm{~A}=\mathrm{Ti}, \mathrm{Zr}, \mathrm{Sn})$ at $1473 \mathrm{~K} . J$ Alloys Compd 1994, 210: 75-81.

[125] Huan ZL, Sun QC, Ma WB, et al. Crystal structure and microwave dielectric properties of $\left(\mathrm{Zn}_{1-x} \mathrm{Co}_{x}\right) \mathrm{TiNb}_{2} \mathrm{O}_{8}$ ceramics. J Alloys Compd 2013, 551: 630-635.

[126] Li LX, Sun H, Lv X, et al. Microstructure and microwave dielectric characteristics of the $\mathrm{Ca}_{x} \mathrm{Zn}_{1-x} \mathrm{TiNb}_{2} \mathrm{O}_{8}$ temperature stable ceramics. J Mater Sci: Mater Electron 2016, 27: 126-133.

[127] Liao QW, Li LX, Zhang P, et al. Correlation of crystal structure and microwave dielectric properties for $\mathrm{Zn}\left(\mathrm{Ti}_{1-x} \mathrm{Sn}_{x}\right) \mathrm{Nb}_{2} \mathrm{O}_{8}$ ceramics. Mater Sci Eng: B 2011, 176: 41-44.

[128] Liao QW, Li LX, Ding X. Phase constitution, structure analysis and microwave dielectric properties of $\mathrm{Zn}_{0.5} \mathrm{Ti}_{1-x} \mathrm{Zr}_{x} \mathrm{NbO}_{4}$ ceramics. Solid State Sci 2012, 14: 1385-1391.

[129] Liao QW, Li LX, Zhang P, et al. Correlation of crystal structure and microwave dielectric properties for $\mathrm{ZnTi}\left(\mathrm{Nb}_{1-x} \mathrm{Ta}_{x}\right)_{2} \mathrm{O}_{8}$ ceramics. Solid State Sci 2011, 13: 1201-1204.

[130] Liao QW, Li LX, Ren X, et al. New low-loss microwave dielectric material $\mathrm{ZnTiNbTaO}_{8} . J$ Am Ceram Soc 2011, 94: 3237-3240.

[131] Park JH, Choi YJ, Nahm S, et al. Crystal structure and microwave dielectric properties of $\mathrm{ZnTi}\left(\mathrm{Nb}_{1-x} \mathrm{Ta}_{x}\right)_{2} \mathrm{O}_{8}$ ceramics. J Alloys Compd 2011, 509: 6908-6912.

[132] Liao QW, Li LX. Structural dependence of microwave dielectric properties of ixiolite structured $\mathrm{ZnTiNb}_{2} \mathrm{O}_{8}$ materials: Crystal structure refinement and Raman spectra study. Dalton Trans 2012, 41: 6963.

[133] Ruan P, Liu P, Guo BC, et al. Microwave dielectric properties of $\mathrm{ZnO}-\mathrm{Nb}_{2} \mathrm{O}_{5}-x \mathrm{TiO}_{2}$ ceramics prepared by reaction-sintering process. J Mater Sci: Mater Electron 2016, 27: 4201-4205.

[134] Bafrooei HB, Feizpour M, Sayyadi-Shahraki A, et al. High-performance $\mathrm{ZnTiNb}_{2} \mathrm{O}_{8}$ microwave dielectric 
ceramics produced from $\mathrm{ZnNb}_{2} \mathrm{O}_{6}-\mathrm{TiO}_{2}$ nano powders. $J$ Alloys Compd 2020, 834: 155082.

[135] Luo WJ, Li LX, Yu SH, et al. Bond theory, terahertz spectra, and dielectric studies in donor-acceptor (Nb-Al) substituted $\mathrm{ZnTiNb}_{2} \mathrm{O}_{8}$ system. J Am Ceram Soc 2019, 102: 4612-4620.

[136] Mei QJ, Li CY, Guo JD, et al. Synthesis, characterization, and microwave dielectric properties of ternary-phase ixiolite-structure $\mathrm{MgTiNb}_{2} \mathrm{O}_{8}$ ceramics. Mater Lett 2015, 145: 7-10.

[137] Lee HJ, Kim IT, Hong KS. Dielectric properties of $\mathrm{AB}_{2} \mathrm{O}_{6}$ compounds at microwave frequencies $(\mathrm{A}=\mathrm{Ca}, \mathrm{Mg}, \mathrm{Mn}$, Co, Ni, Zn, and B = Nb, Ta). Jpn J Appl Phys 1997, 36: L1318-L1320.

[138] Blasse G. Qualitative approach to the structural differences between some mixed metal oxides containing $\mathrm{Sb}^{5+}, \mathrm{Nb}^{5+}$ and $\mathrm{Ta}^{5+}$. J Inorg Nucl Chem 1964, 26: 1191-1199.

[139] Lee HJ, Hong KS, Kim SJ, et al. Dielectric properties OF $\mathrm{MNb}_{2} \mathrm{O}_{6}$ compounds (where $\mathrm{M}=\mathrm{Ca}, \mathrm{Mn}, \mathrm{Co}, \mathrm{Ni}$, or $\mathrm{Zn}$ ). Mater Res Bull 1997, 32: 847-855.

[140] Pullar RC, Breeze JD, Alford NM. Characterization and microwave dielectric properties of $\mathrm{M}^{2+} \mathrm{Nb}_{2} \mathrm{O}_{6}$ ceramics. $J$ Am Ceram Soc 2005, 88: 2466-2471.

[141] Chen YC, Weng MZ, Chang KC. Effect of sintering temperature and time on microwave dielectric properties of $\mathrm{CaNb}_{2} \mathrm{O}_{6}$ ceramics. J Mater Sci: Mater Electron 2014, 25: $844-851$.

[142] $\mathrm{Wu} \mathrm{HT}$, Jiang YS, Wu WB, et al. Synthesis and microwave dielectric properties of columbite-structure $\mathrm{MgNb}_{2} \mathrm{O}_{6}$ ceramics by aqueous sol-gel technique. $J$ Electroceramics 2012, 28: 191-196.

[143] Xia WS, Li LX, Ji LJ, et al. Phase evolution, bond valence and microwave characterization of $\left(\mathrm{Zn}_{1-x} \mathrm{Ni}_{x}\right) \mathrm{Ta}_{2} \mathrm{O}_{6}$ ceramics. Mater Lett 2012, 66: 296-298.

[144] Xia WS, Li LX, Ning PF, et al. Relationship between bond ionicity, lattice energy, and microwave dielectric properties of $\mathrm{Zn}\left(\mathrm{Ta}_{1-x} \mathrm{Nb}_{x}\right)_{2} \mathrm{O}_{6}$ ceramics. J Am Ceram Soc 2012, 95: 2587-2592.

[145] Xia WS, Zhang GY, Shi LW, et al. Enhanced microwave dielectric properties of $\mathrm{ZnTa}_{2} \mathrm{O}_{6}$ ceramics with $\mathrm{Sb}^{5+}$ ion substitution. Mater Lett 2014, 124: 64-66.

[146] $\mathrm{Sp} \mathrm{W,} \mathrm{Jh} \mathrm{L.} \mathrm{Mg-substituted} \mathrm{ZnNb}_{2} \mathrm{O}_{6}-\mathrm{TiO}_{2}$ composite ceramics for $\mathrm{RF} /$ microwaves ceramic capacitors. $J$ Alloys Compd 2011, 509: 8126-8129.

[147] Fu BJ, Zhang YC, Yue H. Microwave dielectric properties of $(1-x) \mathrm{ZnTa}_{2} \mathrm{O}_{6}-x \mathrm{MgNb}_{2} \mathrm{O}_{6}$ ceramics. Ceram Int 2013, 39: 3789-3793.

[148] Zhang YC, You CY, Fu BJ, et al. Tailoring of microwave dielectric properties in $(1-x) \mathrm{ZnTa}_{2} \mathrm{O}_{6}-x \mathrm{NiNb}_{2} \mathrm{O}_{6}$ ceramics. Ferroelectrics 2013, 451: 54-61.

[149] Yu SQ, Tang B, Zhang SR, et al. Phase structure and microwave dielectric properties of Mn-doped $(1-x) \mathrm{ZrTi}_{2} \mathrm{O}_{6}-x \mathrm{ZnNb}_{2} \mathrm{O}_{6}(x=0.13-0.53)$ ceramics. $J$ Mater Sci: Mater Electron 2013, 24: 418-422.

[150] Liu XC, Deng JP. Phase structure and dielectric property of the $\mathrm{ZnNb}_{2} \mathrm{O}_{6}-\left(\mathrm{Mg}_{0.3} \mathrm{Zn}_{0.7}\right) \mathrm{TiO}_{3}$ multiphase ceramics. $J$ Mater Sci: Mater Electron 2012, 23: 506-510.

[151] Yan Z, Huang JL, Gu YJ, et al. Effects of $\mathrm{V}_{2} \mathrm{O}_{5}$ addition on the microstructure and microwave dielectric properties of $\mathrm{ZnNb}_{2} \mathrm{O}_{6}$ ceramics. Adv Mater Res 2012, 476-478: 940-943.

[152] Wu HT, Jiang YS, Yue YL. Low-temperature synthesis and microwave dielectric properties of trirutile-structure $\mathrm{MgTa}_{2} \mathrm{O}_{6}$ ceramics by aqueous sol-gel process. Ceram Int 2012, 38: 5151-5156.

[153] Liu LT, Matusevich A, Garg C, et al. The dominance of paramagnetic loss in microwave dielectric ceramics at cryogenic temperatures. Appl Phys Lett 2012, 101: 252901.

[154] Park JH, Nahm S, Park JG. Crystal structure and microwave dielectric properties of $(1-x) \mathrm{ZnTa}_{2} \mathrm{O}_{6}-x \mathrm{TiO}_{2}$ ceramics. J Alloys Compd 2012, 537: 221-226.

[155] Shahgholi N, Asadian K, Ebadzadeh T. Microstructural and microwave dielectric properties of $\mathrm{ZnNb}_{2} \mathrm{O}_{6}$ ceramics prepared through microwave sintering. Ceram Int 2014, 40: 14335-14339.

[156] Yang HY, Zhang SR, Yang HC, et al. Intrinsic dielectric properties of columbite $\mathrm{ZnNb}_{2} \mathrm{O}_{6}$ ceramics studied by $\mathrm{P}-\mathrm{V}-\mathrm{L}$ bond theory and Infrared spectroscopy. $\mathrm{J} \mathrm{Am}$ Ceram Soc 2019, 102: 5365-5374.

[157] Sebastian MT, Solomon S, Ratheesh R, et al. Preparation, characterization, and microwave properties of $\mathrm{RETiNbO}_{6}$ $(\mathrm{RE}=\mathrm{Ce}, \mathrm{Pr}, \mathrm{Nd}, \mathrm{Sm}, \mathrm{Eu}, \mathrm{Gd}, \mathrm{Tb}, \mathrm{Dy}, \mathrm{Y}$, and $\mathrm{Yb})$ dielectric ceramics. J Am Ceram Soc 2001, 84: 14871489.

[158] Surendran KP, Solomon S, Varma MR, et al. Microwave dielectric properties of $\mathrm{RETiTaO}_{6}(\mathrm{RE}=\mathrm{La}, \mathrm{Ce}, \mathrm{Pr}, \mathrm{Nd}$, $\mathrm{Sm}, \mathrm{Eu}, \mathrm{Gd}, \mathrm{Tb}, \mathrm{Dy}, \mathrm{Ho}, \mathrm{Y}, \mathrm{Er}, \mathrm{Yb}, \mathrm{Al}$, and In) ceramics. $J$ Mater Res 2002, 17: 2561-2566.

[159] Lei Y, Reaney IM, Liu YC, et al. Microwave dielectric properties and microstructures of $\mathrm{RETiNbO}_{6}(\mathrm{RE}=\mathrm{La}$, Sm and Y). Adv Mater Res 2011, 197-198: 285-289.

[160] Zhang J, Zuo RZ. A novel self-composite property-tunable LaTiNbO ${ }_{6}$ microwave dielectric ceramic. Mater Res Bull 2016, 83: 568-572.

[161] Zhang J, Zuo RZ. Sintering behavior, structural phase transition, and microwave dielectric properties of $\mathrm{La}_{1-x} \mathrm{Zn}_{x} \mathrm{TiNbO}_{6-x / 2}$ ceramics. J Am Ceram Soc 2017, 100: 4362-4368.

[162] Zhang J, Zuo RZ. Phase structural transition and microwave dielectric properties in isovalently substituted $\mathrm{La}_{1-x} \operatorname{Ln}_{x} \mathrm{TiNbO}_{6}(\mathrm{Ln}=\mathrm{Ce}, \mathrm{Sm})$ ceramics. Ceram Int 2017 , 43: 7065-7072.

[163] Zhang J, Zuo RZ. Octahedral distortion, phase structural stability, and microwave dielectric properties in equivalently substituted $\mathrm{LaTiNbO}_{6}$ ceramics. J Am Ceram Soc 2017, 100: 5249-5258.

[164] Zhang J, Zuo RZ. Raman scattering and infrared reflectivity study of orthorhombic/monoclinic $\mathrm{LaTiNbO}_{6}$ microwave dielectric ceramics by $\mathrm{A} / \mathrm{B}$-site substitution. 
Ceram Int 2018, 44: 16191-16198.

[165] John F, Solomon S. Dielectric and optical properties of $\mathrm{Ln}_{0.8} \mathrm{Lu}_{0.2} \mathrm{TiNbO}_{6}(\mathrm{Ln}=\mathrm{Ce}, \mathrm{Pr}, \mathrm{Nd} \& \mathrm{Sm})$ ceramics. Phys Lett $A$ 2020, 384: 126731.

[166] Kim DW, Kwon DK, Yoon SH, et al. Microwave dielectric properties of rare-earth ortho-niobates with ferroelasticity. $J$ Am Ceram Soc 2006, 89: 3861-3864.

[167] Zhang P, Song ZK, Wang Y, et al. Effect of ion substitution for $\mathrm{Nd}^{3+}$ based on structural characteristic on the microwave dielectric properties of $\mathrm{NdNbO}_{4}$ ceramic system. J Am Ceram Soc 2014, 97: 976-981.

[168] Song ZK, Zhang P, Wang Y, et al. Improved quality factor of $\mathrm{NdNbO}_{4}$ microwave dielectric ceramic by $\mathrm{Mn}^{2+}$ substitution. J Alloys Compd 2014, 583: 546-549.

[169] Chen YH, Wang H, Pang LX, et al. Effect of $\mathrm{Zn}^{2+}$ substitution on sintering behavior and dielectric properties of $\mathrm{NdNbO}_{4}$ ceramics. Ferroelectrics 2010, 407: 61-68.

[170] Xiao M, Gu QQ, Zhou ZQ, et al. Study of the microwave dielectric properties of $\left(\mathrm{La}_{1-x} \mathrm{Sm}_{x}\right) \mathrm{NbO}_{4}(x=0-0.10)$ ceramics via bond valence and packing fraction. $J \mathrm{Am}$ Ceram Soc 2017, 100: 3952-3960.

[171] Zhang $\mathrm{P}$, Zhao YG. Influence of $\mathrm{Sm}^{3+}$ substitutions for $\mathrm{Nd}^{3+}$ on the microwave dielectric properties of $\left(\mathrm{Nd}_{1-x} \mathrm{Sm}_{x}\right) \mathrm{NbO}_{4}(x=0.02-0.15)$ ceramics. $J$ Alloys Compd 2016, 654: 240-245.

[172] Zhao YG, Zhang P. Complex chemical bond theory, Raman spectra and microwave dielectric properties of low loss ceramics $\mathrm{NdNbO}_{4}-x \mathrm{Al}_{2} \mathrm{O}_{3}$. J Mater Sci: Mater Electron 2016, 27: 2511-2522.

[173] Zhang P, Zhao YG. New temperature stable $\left(\mathrm{Nd}_{1-x} \mathrm{La}_{x}\right)_{1.02} \mathrm{Nb}_{0.988} \mathrm{O}_{4}$ microwave dielectric ceramics. Mater Lett 2015, 161: 620-623.

[174] Zhang P, Zhao YG, Li LX. The correlations among bond ionicity, lattice energy and microwave dielectric properties of $\left(\mathrm{Nd}_{1-x} \mathrm{La}_{x}\right) \mathrm{NbO}_{4}$ ceramics. Phys Chem Chem Phys 2015, 17: 16692-16698.

[175] Pang LX, Zhou D. Modification of $\mathrm{NdNbO}_{4}$ microwave dielectric ceramic by Bi substitutions. J Am Ceram Soc 2019, 102: 2278-2282.

[176] Zhang P, Zhao Y, Liu J, et al. Correlation of crystal structure and microwave dielectric properties of $\mathrm{Nd}_{1.02}\left(\mathrm{Nb}_{1-x} \mathrm{Ta}_{x}\right)_{0.988} \mathrm{O}_{4}$ ceramic. Dalton Trans 2015, 44: 5053-5057.

[177] Zhang P, Zhao YG, Liu J, et al. Enhanced microwave dielectric properties of $\mathrm{NdNbO}_{4}$ ceramic by $\mathrm{Ta}^{5+}$ substitution. J Alloys Compd 2015, 640: 90-94.

[178] Zhang P, Zhao YG, Wang XY. The relationship between bond ionicity, lattice energy, coefficient of thermal expansion and microwave dielectric properties of $\mathrm{Nd}\left(\mathrm{Nb}_{1-x} \mathrm{Sb}_{x}\right) \mathrm{O}_{4}$ ceramics. Dalton Trans 2015, 44: 10932-10938.

[179] Zhang P, Zhao YG, Wang XY. The correlations between electronic polarizability, packing fraction, bond energy and microwave dielectric properties of $\mathrm{Nd}\left(\mathrm{Nb}_{1-x} \mathrm{Sb}_{x}\right) \mathrm{O}_{4}$ ceramics. J Alloys Compd 2015, 644: 621-625.
[180] Yang HC, Zhang SR, Yang HY, et al. Influence of $\left(\mathrm{Al}_{1 / 3} \mathrm{~W}_{2 / 3}\right)^{5+}$ co-substitution for $\mathrm{Nb}^{5+}$ in $\mathrm{NdNbO}_{4}$ and the impact on the crystal structure and microwave dielectric properties. Dalton Trans 2018, 47: 15808-15815.

[181] Yang HC, Zhang SR, Yang HY, et al. Structure stability, bond characteristics and microwave dielectric properties of co-substituted $\mathrm{NdNbO}_{4}$ ceramics. Ceram Int 2019, 45: 3620-3626.

[182] Yang HC, Zhang SR, Yang HY, et al. $\mathrm{NdNb}_{1-x}\left(\mathrm{Mg}_{1 / 4} \mathrm{~W}_{3 / 4}\right)_{x} \mathrm{O}_{4}(0.02 \leqslant x \leqslant 0.06)$ solid solution characterized by infrared spectrum and complex chemical theory. J Alloys Compd 2019, 787: 358-366.

[183] Yang HC, Zhang SR, Yang HY, et al. Bond characteristics, vibrational spectrum and optimized microwave dielectric properties of chemically substituted $\mathrm{NdNbO}_{4}$. Ceram Int 2019, 45: 16940-16947.

[184] Zhang P, Song ZK, Wang Y, et al. Effect of $\mathrm{CaTiO}_{3}$ addition on microwave dielectric properties of $\mathrm{NdNbO}_{4}$ ceramics as multi-function material. J Alloys Compd 2013, 581: 741-746.

[185] Zhang P, Wang T, Xia WS, et al. Microwave dielectric properties of a new ceramic system $\mathrm{NdNbO}_{4}$ with $\mathrm{CaF}_{2}$ addition. $J$ Alloys Compd 2012, 535: 1-4.

[186] Peng Y, Xia WS, Yi CJ, et al. Effects of MgO additive on microwave dielectric properties of $\mathrm{NdNbO}_{4}$ ceramics. $J$ Mater Sci: Mater Electron 2020, 31: 785-790.

[187] Liu LT, Chen YG, Feng ZB, et al. Crystal structure, infrared spectra, and microwave dielectric properties of the $\mathrm{EuNbO}_{4}$ ceramic. Ceram Int 2021, 47: 4321-4326.

[188] Guo D, Zhou D, Li WB, et al. Phase evolution, crystal structure, and microwave dielectric properties of water-insoluble $(1-x) \mathrm{LaNbO}_{4-x} \mathrm{LaVO}_{4}(0 \leqslant x \leqslant 0.9)$ ceramics. Inorg Chem 2017, 56: 9321-9329.

[189] Tang TL, Xia WS, Zhang B, et al. Optimization on quality factor of $\mathrm{LaNbO}_{4}$ microwave dielectric ceramics. J Mater Sci: Mater Electron 2019, 30: 15293-15298.

[190] Chen JW, Fang L, Li J, et al. Packing fraction, bond valence and crystal structure of $\mathrm{AVO}_{4}(\mathrm{~A}=\mathrm{Eu}, \mathrm{Y})$ microwave dielectric ceramics with low permittivity. $J$ Mater Sci: Mater Electron 2020, 31: 19180-19187.

[191] Zhou D, Guo HH, Fu MS, et al. Anomalous dielectric behaviour during the monoclinic to tetragonal phase transition in $\mathrm{La}\left(\mathrm{Nb}_{0.9} \mathrm{~V}_{0.1}\right) \mathrm{O}_{4}$. Inorg Chem Front 2021, 8: 156-163.

[192] Deng JY, Xia WS, Zhang WH, et al. Optimization of sintering behavior and microwave dielectric properties of $\mathrm{LaNbO}_{4}$ ceramics with $\mathrm{NiO} / \mathrm{CoO}$ additive. $J$ Alloys Compd 2021, 859: 158378.

[193] Chen L, Hu MY, Wu P, et al. Thermal expansion performance and intrinsic lattice thermal conductivity of ferroelastic $\mathrm{RETaO}_{4}$ ceramics. J Am Ceram Soc 2019, 102: 4809-4821.

[194] Wu P, Hu MY, Chen L, et al. The effect of $\mathrm{ZrO}_{2}$ alloying on the microstructures and thermal properties of $\mathrm{DyTaO}_{4}$ for high-temperature application. J Am Ceram Soc 2019, 
102: 889-895.

[195] Wu $\mathrm{P}, \mathrm{Hu} \mathrm{MY}$, Chen $\mathrm{L}$, et al. Investigation on microstructures and thermo-physical properties of ferroelastic $\left(\mathrm{Y}_{1-x} \mathrm{Dy}_{x}\right) \mathrm{TaO}_{4}$ ceramics. Materialia 2018, 4: 478-486.

[196] Wu P, Chong XY, Feng J. Effect of $\mathrm{Al}^{3+}$ doping on mechanical and thermal properties of $\mathrm{DyTaO}_{4}$ as promising thermal barrier coating application. $\mathrm{J} \mathrm{Am}$ Ceram Soc 2018, 101: 1818-1823.

[197] Ma Z, Zheng J, Wang S, et al. First-principle calculations of crystal structures, electronic structures, and optical properties of $\mathrm{RETaO}_{4}(\mathrm{RE}=\mathrm{Y}, \mathrm{La}, \mathrm{Sm}, \mathrm{Eu}, \mathrm{Dy}, \mathrm{Er})$. Opt Eng 2018, 57: 017107.

[198] Devesa S, Teixeira SS, Rooney AP, et al. Structural, morphological and dielectric properties of $\mathrm{ErNbO}_{4}$ prepared by the sol-gel method. J Phys Chem Solids 2020, 146: 109619.

[199] Nedelcu L, Geambasu CD, Enculescu M, et al. Intrinsic dielectric loss in $\mathrm{Zr}_{0.8} \mathrm{Sn}_{0.2} \mathrm{TiO}_{4}$ ceramics investigated by terahertz time domain spectroscopy. Materials 2021, 14: 216.

[200] Kumada N, Taki K, Kinomura N. Single crystal structure refinement of a magnesium niobium oxide: $\mathrm{Mg}_{4} \mathrm{Nb}_{2} \mathrm{O}_{9}$. Mater Res Bull 2000, 35: 1017-1021.

[201] Ogawa H, Kan A, Ishihara S, et al. Crystal structure of corundum type $\mathrm{Mg}_{4}\left(\mathrm{Nb}_{2-x} \mathrm{Ta}_{x}\right) \mathrm{O}_{9}$ microwave dielectric ceramics with low dielectric loss. J Eur Ceram Soc 2003, 23: 2485-2488.

[202] Wu HT, Li LX, Zou Q, et al. Synthesis, characterization, and microwave dielectric properties of $\mathrm{Mg}_{4} \mathrm{Nb}_{2} \mathrm{O}_{9}$ ceramics produced through the aqueous sol-gel process. $J$ Alloys Compd 2011, 509: 2232-2237.

[203] Mei QJ, Li CY, Guo JD, et al. Influence of sintering temperature on dielectric properties and crystal structure of corundum-structured $\mathrm{Mg}_{4} \mathrm{Ta}_{2} \mathrm{O}_{9}$ ceramics at microwave frequencies. Ceram Int 2013, 39: 9145-9149.

[204] Wu HT, Wu WB, Yue YL, et al. Synthesis and microwave dielectric properties of pseudobrookite-type structure $\mathrm{Mg}_{5} \mathrm{Nb}_{4} \mathrm{O}_{15}$ ceramics by aqueous sol-gel technique. Ceram Int 2012, 38: 4271-4276.

[205] Kamba S, Petzelt J, Buixaderas E, et al. High frequency dielectric properties of $\mathrm{A}_{5} \mathrm{~B}_{4} \mathrm{O}_{15}$ microwave ceramics. $J$ Appl Phys 2001, 89: 3900-3906.

[206] Guo JD, Li CY, Mei QJ, et al. Effect of MgO excess on structure and microwave dielectric properties of $\mathrm{Mg}_{4} \mathrm{Nb}_{2} \mathrm{O}_{9}$ ceramics. Mater Technol 2015, 30: 134-137.

[207] Yang T, Han ZX, Liu P, et al. Microwave dielectric properties of $\mathrm{Mg}_{4} \mathrm{Nb}_{2} \mathrm{O}_{9}$ ceramics with excess $\mathrm{Mg}(\mathrm{OH})_{2}$ produced by a reaction-sintering process. Ceram Int 2015, 41: S572-S575.

[208] Li BJ, Wang SY, Lin SH, et al. Dielectric properties and crystal structure of $\left(\mathrm{Mg}_{0.95} \mathrm{Ni}_{0.05}\right)_{4}\left(\mathrm{Nb}_{1-x} \mathrm{Ta}_{x}\right)_{2} \mathrm{O}_{9}$ ceramics. J Ceram Soc Japan 2016, 124: 140-144.

[209] Kim JH, Kim ES. Microwave dielectric properties of $\mathrm{Mg}_{4} \mathrm{Nb}_{2} \mathrm{O}_{9}$-based ceramics with $\left(\mathrm{B}_{x} \mathrm{~W}_{1-x}\right)^{5+}$ substitutions at $\mathrm{Nb}^{5+}$ sites $(\mathrm{B}=\mathrm{Li}, \mathrm{Mg}, \mathrm{Al}, \mathrm{Ti})$. Ceram Int 2017, 43: S339-S342.

[210] Li BJ, Wang SY, Chiu CY, et al. Dielectric properties and mixture behavior of $y\left(\mathrm{Mg}_{0.95} \mathrm{Co}_{0.05}\right)_{4} \mathrm{Ta}_{2} \mathrm{O}_{9}-(1-y) \mathrm{CaTiO}_{3}$ ceramic system at microwave frequency. J Alloys Compd 2016, 661: 357-362.

[211] Pakawanit P, Ananta S. Influence of sintering temperature on densification and microstructure of $\mathrm{Zn}_{3} \mathrm{Nb}_{2} \mathrm{O}_{8}$ ceramics derived from nanopowders. Adv Mater Res 2011, 194-196: 656-659.

[212] Amonpattaratkit P, Ngamjarurojana A, Ananta S. Microstructure and dielectric properties of $\mathrm{Zn}_{3} \mathrm{Nb}_{2} \mathrm{O}_{8}$ ceramics prepared by a two-stage sintering method. Ceram Int 2013, 39: S331-S334.

[213] Bian JJ, Wang L, Yuan LL. Microwave dielectric properties of $\mathrm{Li}_{2+x} \mathrm{Ti}_{1-4 x} \mathrm{Nb}_{3 x} \mathrm{O}_{3}(0 \leqslant x \leqslant 0.1)$. Mater Sci Eng: B 2009, 164: 96-100.

[214] Bian JJ, Dong YF. Sintering behavior, microstructure and microwave dielectric properties of $\mathrm{Li}_{2+x} \mathrm{TiO}_{3}(0 \leqslant x \leqslant$ 0.2). Mater Sci Eng: B 2011, 176: 147-151.

[215] Hao YZ, Zhang QL, Zhang J, et al. Enhanced sintering characteristics and microwave dielectric properties of $\mathrm{Li}_{2} \mathrm{TiO}_{3}$ due to nano-size and nonstoichiometry effect. $J$ Mater Chem 2012, 22: 23885.

[216] Izquierdo G, West AR. Phase equilibria in the system $\mathrm{Li}_{2} \mathrm{O}-\mathrm{TiO}_{2}$. Mater Res Bull 1980, 15: 1655-1660.

[217] Mikkelsen JC. Pseudobinary phase relations of $\mathrm{Li}_{2} \mathrm{Ti}_{3} \mathrm{O}_{7} . J$ Am Ceram Soc 1980, 63: 331-335.

[218] Chen GH, Xu HR, Yuan CL. Microstructure and microwave dielectric properties of $\mathrm{Li}_{2} \mathrm{Ti}_{1-x}\left(\mathrm{Zn}_{1 / 3} \mathrm{Nb}_{2 / 3}\right)_{x} \mathrm{O}_{3}$ ceramics. Ceram Int 2013, 39: 4887-4892.

[219] Guo HH, Zhou D, Pang LX, et al. Influence of $\left(\mathrm{Mg}_{1 / 3} \mathrm{Nb}_{2 / 3}\right)$ complex substitutions on crystal structures and microwave dielectric properties of $\mathrm{Li}_{2} \mathrm{TiO}_{3}$ ceramics with extreme low loss. J Materiomics 2018, 4: 368-382.

[220] Chen WS, Hung ML, Hsu CH. Effects of $\left(\mathrm{Co}_{1 / 3} \mathrm{Nb}_{2 / 3}\right)^{4+}$ substitution on microstructure and microwave dielectric properties of $\mathrm{Li}_{2} \mathrm{Ti}_{1-x}\left(\mathrm{Co}_{1 / 3} \mathrm{Nb}_{2 / 3}\right)_{x} \mathrm{O}_{3}$ ceramics for applications in ceramic antenna. J Asian Ceram Soc 2021, 9: 433-442.

[221] Guo HH, Fu MS, Zhou D, et al. Design of a high-efficiency and -gain antenna using novel low-loss, temperature-stable $\mathrm{Li}_{2} \mathrm{Ti}_{1-x}\left(\mathrm{Cu}_{1 / 3} \mathrm{Nb}_{2 / 3}\right)_{x} \mathrm{O}_{3}$ microwave dielectric ceramics. ACS Appl Mater Interfaces 2021, 13: 912-923.

[222] Bian JJ, Dong YF. New high $Q$ microwave dielectric ceramics with rock salt structures: $(1-x) \mathrm{Li}_{2} \mathrm{TiO}_{3}+x \mathrm{MgO}$ system $(0 \leqslant x \leqslant 0.5)$. J Eur Ceram Soc 2010, 30: 325-330.

[223] Huang CL, Tseng YW, Chen JY. High- $Q$ dielectrics using ZnO-modified $\mathrm{Li}_{2} \mathrm{TiO}_{3}$ ceramics for microwave applications. J Eur Ceram Soc 2012, 32: 3287-3295.

[224] Bian JJ, Liang Z, Wang L. Structural evolution and microwave dielectric properties of $\mathrm{Li}_{(3-3 x)} \mathrm{M}_{4 x} \mathrm{Nb}_{(1-x)} \mathrm{O}_{4}$ $(\mathrm{M}=\mathrm{Mg}, \mathrm{Zn} ; 0 \leqslant x \leqslant 0.9)$. J Am Ceram Soc 2011, 94: 
1447-1453.

[225] Wu NX, Bian JJ. Microstructure and microwave dielectric properties of $(1-y) \mathrm{Li}_{3} \mathrm{NbO}_{4}+y \mathrm{Li}_{2} \mathrm{TiO}_{3}\left(\mathrm{Li}_{2} \mathrm{SnO}_{3}\right)$ ceramics. Mater Sci Eng: B 2012, 177: 1793-1798.

[226] Tseng YW, Chen JY, Kuo YC, et al. Low-loss microwave dielectrics using rock salt oxide $\mathrm{Li}_{2} \mathrm{MgTiO}_{4}$. J Alloys Compd 2011, 509: L308-L310.

[227] Chen XL, Zhou HF, Fang L, et al. Microwave dielectric properties and its compatibility with silver electrode of $\mathrm{Li}_{2} \mathrm{MgTi}_{3} \mathrm{O}_{8}$ ceramics. $J$ Alloys Compd 2011, 509: 5829-5832.

[228] Fang L, Chu DJ, Zhou HF, et al. Microwave dielectric properties and low temperature sintering behavior of $\mathrm{Li}_{2} \mathrm{CoTi}_{3} \mathrm{O}_{8}$ ceramic. $J$ Alloys Compd 2011, 509: 1880-1884.

[229] Taghipour Armaki H, Taheri-Nassaj E, Bari M. Phase analysis and improvement of quality factor of $\mathrm{Li}_{2} \mathrm{ZnTi}_{3} \mathrm{O}_{8}$ ceramics by annealing treatment. J Alloys Compd 2013, 581: 757-761.

[230] Lyu XS, Li LX, Cai HC, et al. A new microwave dielectric material $\mathrm{LiNi}_{0.5} \mathrm{Ti}_{0.5} \mathrm{O}_{2}$. Ceram Int 2015, 41: 9168-9171.

[231] Zhou HF, Liu XB, Chen XL, et al. $\mathrm{ZnLi}_{2 / 3} \mathrm{Ti}_{4 / 3} \mathrm{O}_{4}$ : A new low loss spinel microwave dielectric ceramic. J Eur Ceram Soc 2012, 32: 261-265.

[232] Zhou HF, Liu XB, Chen XL, et al. Preparation, phase structure and microwave dielectric properties of a new low cost $\mathrm{MgLi}_{2 / 3} \mathrm{Ti}_{4 / 3} \mathrm{O}_{4}$ compound. Mater Chem Phys 2012, 137: $22-25$.

[233] Zhou HF, Liu XB, Chen XL, et al. Preparation, phase structure and microwave dielectric properties of $\mathrm{CoLi}_{2 / 3} \mathrm{Ti}_{4 / 3} \mathrm{O}_{4}$ ceramic. Mater Res Bull 2012, 47: 1278-1280.

[234] Bi JX, Xing CF, Jiang XS, et al. Characterization and microwave dielectric properties of new low loss $\mathrm{Li}_{2} \mathrm{MgZrO}_{4}$ ceramics. Mater Lett 2016, 184: 269-272.

[235] Fu ZF, Liu P, Ma JL, et al. New high $Q$ low-fired $\mathrm{Li}_{2} \mathrm{Mg}_{3} \mathrm{TiO}_{6}$ microwave dielectric ceramics with rock salt structure. Mater Lett 2016, 164: 436-439.

[236] Zhou HF, Gong JZ, Fan GC, et al. Enhanced sintering ability and microwave dielectric properties of $\mathrm{LiZnNbO}_{4}$ ceramics with pretreatment of raw materials. J Alloys Compd 2016, 665: 113-118.

[237] $\mathrm{Su} \mathrm{CH}$, Huang CL. Investigation of the microwave dielectric properties of $\mathrm{Li}_{2} \mathrm{ZnTi}_{5} \mathrm{O}_{12}$ ceramics. J Alloys Compd 2016, 678: 102-108.

[238] Liu QQ, Pan HL, Tao WH, et al. New rock salt structure dielectric material $\mathrm{Li}_{2} \mathrm{Ni}_{3} \mathrm{TiO}_{6}$ at microwave frequency. $J$ Mater Sci: Mater Electron 2017, 28: 9893-9899.

[239] Bi JX, Li CC, Zhang YH, et al. Crystal structure, infrared spectra and microwave dielectric properties of ultra low-loss $\mathrm{Li}_{2} \mathrm{Mg}_{4} \mathrm{TiO}_{7}$ ceramics. Mater Lett 2017, 196: $128-131$.

[240] Pan HL, Wu HT. Crystal structure, infrared spectra and microwave dielectric properties of new ultra low-loss $\mathrm{Li}_{6} \mathrm{Mg}_{7} \mathrm{Ti}_{3} \mathrm{O}_{16}$ ceramics. Ceram Int 2017, 43: 14484
14487.

[241] Zuo RZ, Qi H, Qin F, et al. A new Li-based ceramic of $\mathrm{Li}_{4} \mathrm{MgSn}_{2} \mathrm{O}_{7}$ : Synthesis, phase evolution and microwave dielectric properties. J Eur Ceram Soc 2018, 38: 5442-5447.

[242] Jiang PB, Hu YD, Bao SX, et al. A novel microwave dielectric ceramic $\mathrm{Li}_{2} \mathrm{NiZrO}_{4}$ with rock salt structure. $R S C$ Adv 2019, 9: 32936-32939.

[243] Wu HT, Kim ES. Characterization of low loss microwave dielectric materials $\mathrm{Li}_{3} \mathrm{Mg}_{2} \mathrm{NbO}_{6}$ based on the chemical bond theory. J Alloys Compd 2016, 669: 134-140.

[244] Pei CJ, Hou CD, Li Y, et al. A low $\varepsilon_{\mathrm{r}}$ and temperature-stable $\mathrm{Li}_{3} \mathrm{Mg}_{2} \mathrm{SbO}_{6}$ microwave dielectric ceramics. J Alloys Compd 2019, 792: 46-49.

[245] Li J, Zhang ZW, Tian YF, et al. Crystal structure and microwave dielectric properties of a novel rock-salt type $\mathrm{Li}_{3} \mathrm{MgNbO}_{5}$ ceramic. J Mater Sci 2020, 55: 15643-15652.

[246] Zhang X, Jiang ZH, Tang B, et al. A new series of low-loss multicomponent oxide microwave dielectrics with a rock salt structure: $\mathrm{Li}_{5} \mathrm{MgABO}_{8}(\mathrm{~A}=\mathrm{Ti}, \mathrm{Sn} ; \mathrm{B}=\mathrm{Nb}, \mathrm{Ta})$. Ceram Int 2020, 46: 10332-10340.

[247] Zhang X, Fang ZX, Yang HY, et al. Lattice evolution, ordering transformation and microwave dielectric properties of rock-salt $\mathrm{Li}_{3+x} \mathrm{Mg}_{2-2 x} \mathrm{Nb}_{1-x} \mathrm{Ti}_{2 x} \mathrm{O}_{6}$ solidsolution system: A newly developed pseudo ternary phase diagram. Acta Mater 2021, 206: 116636.

[248] Gu FF, Chen GH, Li XQ, et al. Structural and microwave dielectric properties of the $(1-x) \mathrm{Li}_{3} \mathrm{NbO}_{4}-x \mathrm{Ca}_{0.8} \mathrm{Sr}_{0.2} \mathrm{TiO}_{3}$ thermally stable ceramics. Mater Chem Phys 2015, 167: 354-359.

[249] Yao GG, Hu XS, Tian XL, et al. Synthesis and microwave dielectric properties of $\mathrm{Li}_{2} \mathrm{MgTiO}_{4}$ ceramics. Ceram Int 2015, 41: S563-S566.

[250] Du H, Li CC, Liu FL, et al. Influence of ionic substitution on the microwave dielectric properties of $\mathrm{Li}_{2} \mathrm{Mg}_{0.95} \mathrm{~A}_{0.05} \mathrm{TiO}_{4}(\mathrm{~A}=\mathrm{Ni}, \mathrm{Co}, \mathrm{Mn}, \mathrm{Zn})$ ceramics. $J$ Mater Sci: Mater Electron 2017, 28: 8304-8308.

[251] Wang P, Wang YR, Bi JX, et al. Effects of $\mathrm{Zn}^{2+}$ substitution on the crystal structure, Raman spectra, bond energy and microwave dielectric properties of $\mathrm{Li}_{2} \mathrm{MgTiO}_{4}$ ceramics. J Alloys Compd 2017, 721: 143-148.

[252] Xing CF, Liu QQ, Wu HT. Sintering characteristics, crystal structure, and microwave dielectric properties of $\mathrm{Li}_{2}\left(\mathrm{Mg}_{0.9} \mathrm{~A}_{0.1}\right)_{4} \mathrm{TiO}_{7}\left(\mathrm{~A}=\mathrm{Co}^{2+}, \mathrm{Ni}^{2+}, \mathrm{Mg}^{2+}, \mathrm{Zn}^{2+}, \mathrm{Ca}^{2+}\right) . J$ Mater Sci: Mater Electron 2019, 30: 302-307.

[253] Xing CF, Wu HT. Crystal structure and microwave dielectric properties of $\mathrm{Li}_{4} \mathrm{Mg}_{3}\left[\mathrm{Ti}_{1-x}\left(\mathrm{Mg}_{1 / 3} \mathrm{Ta}_{2 / 3}\right)_{x}\right]_{2} \mathrm{O}_{9}$ $(x=0-0.4)$ ceramics. Ceram Int 2019, 45: 4142-4145.

[254] Lu XP, Zheng Y, Huang Q, et al. Correlation of heating rates, crystal structures, and microwave dielectric properties of $\mathrm{Li}_{2} \mathrm{ZnTi}_{3} \mathrm{O}_{8}$ ceramics. J Electron Mater 2015 , 44: 4243-4249.

[255] Zhou HF, Wang N, Gong JZ, et al. Processing of low-fired glass-free $\mathrm{Li}_{2} \mathrm{MgTi}_{3} \mathrm{O}_{8}$ microwave dielectric ceramics. $J$ Alloys Compd 2016, 688: 8-13. 
[256] Tajik Z, Sayyadi-Shahraki A, Taheri-Nassaj E, et al. Effect of synthesis and sintering technique on the long-range 1:3 cation ordering and microwave dielectric loss of $\mathrm{Li}_{2} \mathrm{ZnTi}_{3} \mathrm{O}_{8}$ ceramics. Ceram Int 2020, 46: 20905-20913.

[257] Huang $\mathrm{CL}, \mathrm{Su} \mathrm{CH}$, Chang $\mathrm{CM}$. High $Q$ microwave dielectric ceramics in the $\mathrm{Li}_{2}\left(\mathrm{Zn}_{1-x} \mathrm{~A}_{x}\right) \mathrm{Ti}_{3} \mathrm{O}_{8}(\mathrm{~A}=\mathrm{Mg}, \mathrm{Co}$; $x=0.02-0.1)$ system. $J$ Am Ceram Soc 2011, 94: 41464149.

[258] Fang L, Chu DJ, Zhou HF, et al. Microwave dielectric properties of temperature stable $\mathrm{Li}_{2} \mathrm{Zn}_{x} \mathrm{Co}_{1-x} \mathrm{Ti}_{3} \mathrm{O}_{8}$ ceramics. J Alloys Compd 2011, 509: 8840-8844.

[259] Wang LJ, Sun QC, Ma WB, et al. Microwave dielectric characteristics of $\mathrm{Li}_{2}\left(\mathrm{Mg}_{0.94} \mathrm{M}_{0.06}\right) \mathrm{Ti}_{3} \mathrm{O}_{8}(\mathrm{M}=\mathrm{Zn}, \mathrm{Co}$, and $\mathrm{Mn})$ ceramics. Ceram Int 2013, 39: 5185-5190.

[260] Ren HS, Wu ZL, He F, et al. Investigation on phase and microstructures of a temperature stable high- $Q$ $\mathrm{Li}_{2} \mathrm{Zn}_{0.95} \mathrm{Sr}_{0.05} \mathrm{Ti}_{3} \mathrm{O}_{8}$ microwave dielectric ceramic. $J$ Mater Sci: Mater Electron 2019, 30: 8154-8159.

[261] Ren HS, Xie TY, Wu ZL, et al. Crystal structure, phase evolution and dielectric properties in the $\mathrm{Li}_{2} \mathrm{ZnTi}_{3} \mathrm{O}_{8}-$ $\mathrm{SrTiO}_{3}$ system as temperature stable high- $Q$ material. $J$ Alloys Compd 2019, 797: 18-25.

[262] Tian S, Liao ZL, Wang H, et al. Influence of $\mathrm{Ca}_{x} \mathrm{Sr}_{1-x}(0 \leqslant$ $x \leqslant 1)$ substitution for $\mathrm{Zn}$ on microwave dielectric properties of $\mathrm{Li}_{2} \mathrm{ZnTi}_{3} \mathrm{O}_{8}$ ceramic as temperature stable materials. J Wuhan Univ Technol Mater Sci Ed 2020, 35: 686-690.

[263] Liu XB, Zhou HF, Chen XL, et al. Phase structure and microwave dielectric properties of $(1-x) \mathrm{Li}_{2} \mathrm{Zn}_{3} \mathrm{Ti}_{4} \mathrm{O}_{12}-$ $x \mathrm{TiO}_{2}$ ceramics. J Alloys Compd 2012, 515: 22-25.

[264] Wang W, Zhou HF, Chen XL, et al. Crystal structure and optimized microwave dielectric properties of $(1-x) \mathrm{LiZn}_{0.5} \mathrm{Ti}_{1.5} \mathrm{O}_{4}-x \mathrm{TiO}_{2}$ ceramics for application in dielectric resonator. J Mater Sci: Mater Electron 2013, 24: 2641-2645.

[265] Bari M, Taheri-Nassaj E, Taghipour-Armaki H. Phase evolution, microstructure, and microwave dielectric properties of reaction-sintered $\mathrm{Li}_{2} \mathrm{ZnTi}_{3} \mathrm{O}_{8}$ ceramic obtained using nanosized $\mathrm{TiO}_{2}$ reagent. J Electron Mater 2015, 44: 3670-3676.

[266] Bari M, Taheri-Nassaj E, Taghipour-Armaki H. Role of nano- and micron-sized particles of $\mathrm{TiO}_{2}$ additive on microwave dielectric properties of $\mathrm{Li}_{2} \mathrm{ZnTi}_{3} \mathrm{O}_{8}-$ 4 wt $\% \mathrm{TiO}_{2}$ ceramics. J Am Ceram Soc 2013, 96: 37373741 .

[267] Zhang P, Wang Y, Liu J, et al. A high improved quality factor of $\mathrm{Li}_{2} \mathrm{MgTi}_{3} \mathrm{O}_{8}$ microwave dielectric ceramics system. Mater Lett 2014, 123: 195-197.

[268] Zhang P, Zhao YG. High- $Q$ microwave dielectric materials of $\mathrm{Li}_{2} \mathrm{ZnTi}_{3} \mathrm{O}_{8}$ ceramics with $\mathrm{SnO}_{2}$ additive. Ceram Int 2016, 42: 2882-2886.

[269] Zhang YD, Han J, Liang R, et al. Novel temperature stable $\mathrm{Li}_{2} \mathrm{TiO}_{3}$-based microwave dielectric ceramics with low loss. Mater Lett 2015, 153: 118-120.

[270] Li W, Li JH, Shen JX, et al. Crystal structure, Raman spectra, and microwave dielectric properties of high- $Q$ $\mathrm{Li}_{2} \mathrm{ZnTi}_{3} \mathrm{O}_{8}$ systems with $\mathrm{Nb}_{2} \mathrm{O}_{5}$ addition. Ceram Int 2021 , 47: 8601-8609.

[271] Zhang BW, Li LX, Luo WJ. Oxygen vacancy regulation and its high frequency response mechanism in microwave ceramics. J Mater Chem C 2018, 6: 11023-11034.

[272] Zhang P, Xie H, Zhao YG, et al. Microwave dielectric properties of low loss $\mathrm{Li}_{2}\left(\mathrm{Mg}_{0.95} \mathrm{~A}_{0.05}\right)_{3} \mathrm{TiO}_{6}\left(\mathrm{~A}=\mathrm{Ca}^{2+}, \mathrm{Ni}^{2+}\right.$, $\mathrm{Zn}^{2+}, \mathrm{Mn}^{2+}$ ) ceramics system. $J$ Alloys Compd 2016, 689: 246-249.

[273] Shi XL, Zhang HW, Zhang DN, et al. Structure and microwave dielectric properties of $\mathrm{Li}_{2} \mathrm{Mg}_{3} \mathrm{Ti}_{1-x}\left(\mathrm{Al}_{1 / 2} \mathrm{Nb}_{1 / 2}\right)_{x} \mathrm{O}_{6}$ ceramics. Ceram Int 2020, 46: 13737-13742.

[274] Zhan Y, Li LX. Low-permittivity and high- $Q$ value $\mathrm{Li}_{2} \mathrm{Mg}_{3} \mathrm{Ti}_{1-x}\left(\mathrm{Zn}_{1 / 3} \mathrm{Nb}_{2 / 3}\right)_{x} \mathrm{O}_{6}$ microwave dielectric ceramics for microstrip antenna applications in $5 \mathrm{G}$ millimeter wave. J Alloys Compd 2021, 857: 157608.

[275] Fang ZX, Tang B, Si F, et al. Phase evolution, structure and microwave dielectric properties of $\mathrm{Li}_{2+x} \mathrm{Mg}_{3} \mathrm{SnO}_{6}(x=$ 0.00-0.12) ceramics. Ceram Int 2017, 43: 13645-13652.

[276] Fang ZX, Tang B, Si F, et al. Temperature stable and high-Q microwave dielectric ceramics in the $\mathrm{Li}_{2} \mathrm{Mg}_{3-x} \mathrm{Ca}_{x} \mathrm{TiO}_{6}$ system $(x=0.00-0.18)$. Ceram Int 2017 , 43: $1682-1687$.

[277] Fang ZX, Tang B, Yuan Y, et al. Structure and microwave dielectric properties of the $\mathrm{Li}_{2 / 3(1-x)} \mathrm{Sn}_{1 / 3(1-x)} \mathrm{Mg}_{x} \mathrm{O}$ systems $(x=0-4 / 7)$. J Am Ceram Soc 2018, 101: 252-264.

[278] Xie TY, Zhang LZ, Ren HS, et al. A novel temperaturestable and low-loss microwave dielectric using $\mathrm{Ca}_{0.8} \mathrm{Sr}_{0.2} \mathrm{TiO}_{3}$-modified $\mathrm{Li}_{2} \mathrm{Mg}_{3} \mathrm{TiO}_{6}$ ceramics. $J$ Mater Sci: Mater Electron 2017, 28: 13705-13709.

[279] Zhou HF, Tan XH, Huang J, et al. Sintering behavior, phase evolution and microwave dielectric properties of thermally stable $\mathrm{Li}_{2} \mathrm{O}-3 \mathrm{MgO}-m \mathrm{TiO}_{2}$ ceramics $(1 \leqslant m \leqslant$ 6). Ceram Int 2017, 43: 3688-3692.

[280] Pan HL, Xing CF, Jiang XS, et al. Characterization on low loss dielectric $\mathrm{Li}_{2} \mathrm{MgTiO}_{4}$ ceramics based on chemical bond theory at microwave frequency. $J$ Alloys Compd 2016, 688: 416-421.

[281] Bi JX, Niu YJ, Wu HT. $\mathrm{Li}_{4} \mathrm{Mg}_{3} \mathrm{Ti}_{2} \mathrm{O}_{9}$ : A novel low-loss microwave dielectric ceramic for LTCC applications. Ceram Int 2017, 43: 7522-7530.

[282] Pan HL, Cheng L, Wu HT. Relationships between crystal structure and microwave dielectric properties of $\mathrm{Li}_{2}\left(\mathrm{Mg}_{1-x} \mathrm{Co}_{x}\right)_{3} \mathrm{TiO}_{6}(0 \leqslant x \leqslant 0.4)$ ceramics. Ceram Int 2017, 43: 15018-15026.

[283] Fu ZF, Liu P, Ma JL, et al. Novel series of ultra-low loss microwave dielectric ceramics: $\mathrm{Li}_{2} \mathrm{Mg}_{3} \mathrm{BO}_{6}(\mathrm{~B}=\mathrm{Ti}, \mathrm{Sn}$, Zr). J Eur Ceram Soc 2016, 36: 625-629.

[284] Bi JX, Xing CF, Yang CH, et al. Phase composition, microstructure and microwave dielectric properties of rock salt structured $\mathrm{Li}_{2} \mathrm{ZrO}_{3}-\mathrm{MgO}$ ceramics. J Eur Ceram Soc 2018, 38: 3840-3846.

[285] Liu LT, Wang LG, Du JL, et al. Effects of $\left(\mathrm{Mg}_{1 / 3} \mathrm{Sb}_{2 / 3}\right)^{4+}$ substitutions on the sintering behaviors and microwave 
dielectric properties of $\mathrm{Li}_{2} \mathrm{Mg}_{4} \mathrm{Zr}_{1-x}\left(\mathrm{Mg}_{1 / 3} \mathrm{Sb}_{2 / 3}\right)_{x} \mathrm{O}_{7}$ ceramics. J Alloys Compd 2021, 865: 158942.

[286] Shi XL, Zhang HW, Zhang DN, et al. Effect of zirconium deficiency on structure characteristics, morphology and microwave dielectric properties of $\mathrm{Li}_{2} \mathrm{Mg}_{3} \mathrm{Zr}_{1-x} \mathrm{O}_{6}$ ceramics. Ceram Int 2021, 47: 12567-12573.

[287] Wang G, Zhang DN, Gan GW, et al. Synthesis, crystal structure and low loss of $\mathrm{Li}_{3} \mathrm{Mg}_{2} \mathrm{NbO}_{6}$ ceramics by reaction sintering process. Ceram Int 2019, 45: 19766-19770.

[288] Xing CF, Bi JX, Wu HT. Effect of Co-substitution on microwave dielectric properties of $\mathrm{Li}_{3}\left(\mathrm{Mg}_{1-x} \mathrm{Co}_{x}\right)_{2} \mathrm{NbO}_{6}$ $(0.00 \leqslant x \leqslant 0.10)$ ceramics. J Alloys Compd 2017, 719: 58-62.

[289] Zhang P, Liu L, Xiao M, et al. A novel temperature stable and high $Q$ microwave dielectric ceramic in $\mathrm{Li}_{3}\left(\mathrm{Mg}_{1-x} \mathrm{Mn}_{x}\right)_{2} \mathrm{NbO}_{6}$ system. J Mater Sci: Mater Electron 2017, 28: 12220-12225.

[290] Zhang P, Sun KX, Xiao M, et al. Crystal structure, densification, and microwave dielectric properties of $\mathrm{Li}_{3} \mathrm{Mg}_{2}\left(\mathrm{Nb}_{(1-x)} \mathrm{Mo}_{x}\right) \mathrm{O}_{6+x / 2}(0 \leqslant x \leqslant 0.08)$ ceramics. $J$ Am Ceram Soc 2019, 102: 4127-4135.

[291] Wang G, Zhang DN, Huang X, et al. Crystal structure and enhanced microwave dielectric properties of $\mathrm{Ta}^{5+}$ substituted $\mathrm{Li}_{3} \mathrm{Mg}_{2} \mathrm{NbO}_{6}$ ceramics. J Am Ceram Soc 2020, 103: 214-223.

[292] Pei CJ, Li Y, Hou CD, et al. Sintering behavior and microwave dielectric properties of $\mathrm{V}^{5+}$ substituted $\mathrm{Li}_{3} \mathrm{Mg}_{2} \mathrm{SbO}_{6}$ ceramics. J Mater Sci: Mater Electron 2019, 30: 14495-14499.

[293] Pei CJ, Tan JJ, Li Y, et al. Effect of Sb-site nonstoichiometry on the structure and microwave dielectric properties of $\mathrm{Li}_{3} \mathrm{Mg}_{2} \mathrm{Sb}_{1-x} \mathrm{O}_{6}$ ceramics. $J A d v$ Ceram 2020, 9: 588-594.

[294] Li H, Zhang PC, Chen XQ, et al. Effect of $\mathrm{Zn}^{2+}$ substitution for $\mathrm{Mg}^{2+}$ in $\mathrm{Li}_{3} \mathrm{Mg}_{2} \mathrm{SbO}_{6}$ and the impact on the bond characteristics and microwave dielectric properties. $J$ Alloys Compd 2020, 832: 155043.

[295] Zhang P, Hao MM, Mao XR, et al. Effects of $\mathrm{W}^{6+}$ substitution on crystal structure and microwave dielectric properties of $\mathrm{Li}_{3} \mathrm{Mg}_{2} \mathrm{NbO}_{6}$ ceramics. Ceram Int 2020, 46: 21336-21342.

[296] Wang G, Zhang DN, Li J, et al. Crystal structure, bond energy, Raman spectra, and microwave dielectric properties of Ti-doped $\mathrm{Li}_{3} \mathrm{Mg}_{2} \mathrm{NbO}_{6}$ ceramics. $\mathrm{J} \mathrm{Am}$ Ceram Soc 2020, 103: 4321-4332.

[297] Zhang P, Sun KX, Mao XR, et al. Crystal structures and high microwave dielectric properties in $\mathrm{Li}^{+} / \mathrm{Ti}^{4+}$ ions co-doped $\mathrm{Li}_{3} \mathrm{Mg}_{2} \mathrm{NbO}_{6}$ ceramics. Ceram Int 2020, 46: 8097-8103.

[298] Zhang P, Hao MM, Xiao M. Microwave dielectric properties of $\mathrm{Li}_{3} \mathrm{Mg}_{2} \mathrm{NbO}_{6}$-based ceramics with $\left(\mathrm{M}_{x} \mathrm{~W}_{1-x}\right)^{5+}\left(\mathrm{M}=\mathrm{Li}^{+}, \mathrm{Mg}^{2+}, \mathrm{Al}^{3+}, \mathrm{Ti}^{4+}\right)$ substitutions at $\mathrm{Nb}^{5+}$ sites. J Alloys Compd 2021, 853: 157386.

[299] Wang G, Zhang HW, Huang X, et al. Crystal structure and enhanced microwave dielectric properties of nonstoichiometric $\mathrm{Li}_{3} \mathrm{Mg}_{2+x} \mathrm{NbO}_{6}$ ceramics. Mater Lett 2019 , 235: 84-87.

[300] Chu X, Gan L, Ren SQ, et al. Low-loss and temperature-stable $(1-x) \mathrm{Li}_{2} \mathrm{TiO}_{3}-x \mathrm{Li}_{3} \mathrm{Mg}_{2} \mathrm{NbO}_{6}$ microwave dielectric ceramics. Ceram Int 2020, 46: 8413-8419.

[301] Zhang X, Tang B, Fang ZX, et al. Structural evolution and microwave dielectric properties of a novel $\mathrm{Li}_{3} \mathrm{Mg}_{2-x / 3} \mathrm{Nb}_{1-2 x / 3} \mathrm{Ti}_{x} \mathrm{O}_{6}$ system with a rock salt structure. Inorg Chem Front 2018, 5: 3113-3125.

[302] Zhang X, Zhang X, Fang ZX, et al. Effects of lattice evolution and ordering on the microwave dielectric properties of tin-modified $\mathrm{Li}_{3} \mathrm{Mg}_{2} \mathrm{NbO}_{6}$-based ceramics. $J$ Phys Chem C 2020, 124: 22069-22081.

[303] Qin F, Zhang S, Zuo RZ. Ultralow-loss and thermally stable $\mathrm{Li}_{4} \mathrm{MgSn}_{2-1.25 x} \mathrm{Nb}_{x} \mathrm{O}_{7}$ microwave dielectric ceramics. J Mater Sci: Mater Electron 2020, 31: 5567-5572.

[304] Li L, Chen XM. Frequency-dependent Qf value of low-loss $\mathrm{Ba}_{2} \mathrm{Ti}_{9} \mathrm{O}_{20}$ ceramics at microwave frequencies. Ceram Int 2012, 38: 6831-6835.

[305] Huang XL, Song Y, Wang FP. Microwave dielectric properties of $\mathrm{BaTi}_{4} \mathrm{O}_{9}-\mathrm{BaSm}_{2} \mathrm{Ti}_{4} \mathrm{O}_{12}$ composite ceramics. J Ceram Soc Japan 2013, 121: 880-883.

[306] Yang QH, Luo T, Yu T, et al. Improvement of microwave dielectric properties of $\mathrm{Ba}_{2} \mathrm{Ti}_{9} \mathrm{O}_{20}$ ceramics using $\left[\mathrm{Zn}_{1 / 3} \mathrm{Nb}_{2 / 3}\right]^{4+}$ substitution for $\mathrm{Ti}^{4+}$. J Mater Sci: Mater Electron 2020, 31: 15184-15191.

[307] Jawahar IN, Mohanan P, Sebastian MT. $\mathrm{A}_{5} \mathrm{~B}_{4} \mathrm{O}_{15}(\mathrm{~A}=\mathrm{Ba}$, $\mathrm{Sr}, \mathrm{Mg}, \mathrm{Ca}, \mathrm{Zn} ; \mathrm{B}=\mathrm{Nb}, \mathrm{Ta})$ microwave dielectric ceramics. Mater Lett 2003, 57: 4043-4048.

[308] Zheng JJ, Yang YK, Wu HT, et al. Structure, infrared spectra and microwave dielectric properties of the novel $\mathrm{Eu}_{2} \mathrm{TiO}_{5}$ ceramics. J Am Ceram Soc 2020, 103: 43334341.

[309] Niu H, Gou HY, Ewing RC, et al. First-principles investigation of structural, elastic and electronic properties of lanthanide titanate oxides $\mathrm{Ln}_{2} \mathrm{TiO}_{5}$. MRS Online Proc Libr 2011, 1298: 85-90.

[310] Ohsato $H$. Science of tungstenbronze-type like $\mathrm{Ba}_{6-3 x} \mathrm{R}_{8+2 x} \mathrm{Ti}_{18} \mathrm{O}_{54}(\mathrm{R}=$ rare earth) microwave dielectric solid solutions. J Eur Ceram Soc 2001, 21: 2703-2711.

[311] Suvorov D, Valant M, Kolar D. The role of dopants in tailoring the microwave properties of $\mathrm{Ba}_{6-x} \mathrm{R}_{8+2 / 3 x} \mathrm{Ti}_{18} \mathrm{O}_{54}$ $\mathrm{R}=(\mathrm{La}-\mathrm{Gd})$ Ceramics. J Mater Sci 1997, 32: 6483-6488.

[312] Snashall AL, Norén L, Liu Y, et al. Phase analysis and microwave dielectric properties of $\mathrm{BaO}-\mathrm{Nd}_{2} \mathrm{O}_{3}-5 \mathrm{TiO}_{2}$ composite ceramics using variable size $\mathrm{TiO}_{2}$ reagents. Ceram Int 2012, 38: S153-S157.

[313] Yao XG, Lin HX, Zhao XY, et al. Effects of $\mathrm{Al}_{2} \mathrm{O}_{3}$ addition on the microstructure and microwave dielectric properties of $\mathrm{Ba}_{4} \mathrm{Nd}_{9.33} \mathrm{Ti}_{18} \mathrm{O}_{54}$ ceramics. Ceram Int 2012, 38: 6723-6728.

[314] Chen HT, Xiong Z, Yuan Y, et al. Dependence of microwave dielectric properties on site substitution in $\mathrm{Ba}_{3.75} \mathrm{Nd}_{9.5} \mathrm{Ti}_{18} \mathrm{O}_{54}$ ceramic. J Mater Sci: Mater Electron 
2016, 27: 10951-10957.

[315] Setasuwon P, Freer R, Azough F, et al. $\left(\mathrm{Ba}_{1-y} \mathrm{~Pb}_{y}\right)_{3 \cdot{ }_{7}} \mathrm{Nd}_{9.5} \mathrm{Ti}_{18} \mathrm{O}_{54}$ and $\left(\mathrm{Ba}_{1-y} \mathrm{Sr}_{y}\right)_{3.75} \mathrm{Nd}_{9.5} \mathrm{Ti}_{18} \mathrm{O}_{54}$ microwave dielectric ceramics: Effect of $\mathrm{Pb}$ and $\mathrm{Sr}$ substitution on dielectric properties. Br Ceram Trans 2002, 101: 237-241.

[316] Muhammad R, Iqbal Y, Rambo CR. Characterization of $\mathrm{Ba}_{4 \cdot 5} \mathrm{Re}_{9} \mathrm{Ti}_{18} \mathrm{O}_{54}(\mathrm{Re}=\mathrm{La}, \mathrm{Nd})$ microwave dielectric ceramics. J Mater Sci: Mater Electron 2014, 25: 1652-1656.

[317] Huang BY, Wang ZF, Chen T, et al. Microstructure and microwave dielectric properties of $\mathrm{Ba}_{4.2} \mathrm{Nd}_{9.2} \mathrm{Ti}_{18-x} \mathrm{Sn}_{x} \mathrm{O}_{54}$ $(x=0,0.25,0.5,1,1.5,2)$ ceramics. J Mater Sci: Mater Electron 2015, 26: 3375-3379.

[318] Guo X, Tang B, Chen HT, et al. Microwave dielectric properties and microstructure of $\left(\mathrm{Ba}_{0.98} \mathrm{Sr}_{0.02}\right)_{3.75} \mathrm{Nd}_{9.5} \mathrm{Ti}_{18-x}\left(\mathrm{Zn}_{1 / 3} \mathrm{Nb}_{2 / 3}\right)_{x} \mathrm{O}_{54}$ ceramics. $J$ Mater Sci: Mater Electron 2015, 26: 6182-6188.

[319] Guo X, Tang B, Liu JQ, et al. Microwave dielectric properties and microstructure of $\mathrm{Ba}_{6-3 x} \mathrm{Nd}_{8+2 x} \mathrm{Ti}_{18-y}\left(\mathrm{Cr}_{1 / 2} \mathrm{Nb}_{1 / 2}\right)_{y} \mathrm{O}_{54}$ ceramics. $J$ Alloys Compd 2015, 646: 512-516.

[320] An SB, Jiang J, Wang JZ, et al. Microwave dielectric property modification of $\mathrm{Ba}_{4} \mathrm{Nd}_{9.33} \mathrm{Ti}_{18} \mathrm{O}_{54}$ ceramics by the substitution of $\left(\mathrm{Al}_{0.5} \mathrm{Nb}_{0.5}\right)^{4+}$ for $\mathrm{Ti}^{4+}$ and the addition of $\mathrm{NdAlO}_{3}$. Ceram Int 2020, 46: 3960-3967.

[321] Xiong Z, Tang B, Fang ZX, et al. Crystal structure, Raman spectroscopy and microwave dielectric properties of $\mathrm{Ba}_{3.75} \mathrm{Nd}_{9.5} \mathrm{Ti}_{18-z}\left(\mathrm{Al}_{1 / 2} \mathrm{Nb}_{1 / 2}\right)_{z} \mathrm{O}_{54}$ ceramics. J Alloys Compd 2017, 723: 580-588.

[322] Zhou LL, Zhou HQ, Shao H, et al. Microstructure and microwave dielectric properties of $\mathrm{Ba}_{6-3 x} \mathrm{Sm}_{8+2 x} \mathrm{Ti}_{18} \mathrm{O}_{54}$ ceramics with various $\mathrm{Ba}_{x} \mathrm{Sr}_{1-x} \mathrm{TiO}_{3}$ additions. $J$ Rare Earths 2012, 30: 142-145.

[323] Xu Y, Fu RL, Agathopoulos S, et al. Synthesis and microwave dielectric properties of $\mathrm{BaO}-\mathrm{Sm}_{2} \mathrm{O}_{3}-5 \mathrm{TiO}_{2}$ ceramics with $\mathrm{NdAlO}_{3}$ additions. Ceram Int 2016, 42: 14573-14580.

[324] Yao XG, Lin HX, Chen W, et al. Anti-reduction of $\mathrm{Ti}^{4+}$ in $\mathrm{Ba}_{4.2} \mathrm{Sm}_{9.2} \mathrm{Ti}_{18} \mathrm{O}_{54}$ ceramics by doping with $\mathrm{MgO}, \mathrm{Al}_{2} \mathrm{O}_{3}$ and $\mathrm{MnO}_{2}$. Ceram Int 2012, 38: 3011-3016.

[325] Wang G, Fu QY, Shi H, et al. Novel thermally stable, high quality factor $\mathrm{Ba}_{4}\left(\mathrm{Pr}_{0.4} \mathrm{Sm}_{0.6}\right)_{28 / 3} \mathrm{Ti}_{18-y} \mathrm{Ga}_{4 y / 3} \mathrm{O}_{54}$ microwave dielectric ceramics. $J$ Am Ceram Soc 2020, 103: 2520-2527.

[326] Wang G, Fu QY, Guo PJ, et al. A/B-site cosubstituted $\mathrm{Ba}_{4} \mathrm{Pr}_{28 / 3} \mathrm{Ti}_{18} \mathrm{O}_{54}$ microwave dielectric ceramics with temperature stable and high $Q$ in a wide range. Ceram Int 2020, 46: 11474-11483.

[327] Roth RS, Rawn CJ, Lindsay CG, et al. Phase equilibria and crystal chemistry of the binary and ternary barium polytitanates and crystallography of the barium zinc polytitanates. J Solid State Chem 1993, 104: 99-118.

[328] Tang B, Yu SQ, Chen HT, et al. The influence of $\mathrm{Cu}$ substitution on the microwave dielectric properties of
BaZn $\mathrm{Ti}_{4} \mathrm{O}_{11}$ ceramics. J Alloys Compd 2013, 551: 463-467.

[329] Yu SQ, Tang B, Zhang SR, et al. Temperature stable high-Q microwave dielectric ceramics in $(1-x) \mathrm{BaTi}_{4} \mathrm{O}_{9-x} \mathrm{BaZn}_{2} \mathrm{Ti}_{4} \mathrm{O}_{11}$ system. Mater Lett 2012, 67: 293-295.

[330] Yu SQ, Tang $\mathrm{B}$, Zhang $\mathrm{X}$, et al. Improved high- $Q$ microwave dielectric ceramics in $\mathrm{CuO}$-doped $\mathrm{BaTi}_{4} \mathrm{O}_{9}-$ $\mathrm{BaZn}_{2} \mathrm{Ti}_{4} \mathrm{O}_{11}$ system. J Am Ceram Soc 2012, 95: 19391943.

[331] Yu SQ, Zhang SR, Tang B, et al. Microwave dielectric properties of $\mathrm{BaO}-2(1-x) \mathrm{ZnO}-x \mathrm{Nd}_{2} \mathrm{O}_{3}-4 \mathrm{TiO}_{2}(x=0-1.0)$ ceramics. Ceram Int 2012, 38: 613-618.

[332] Yang XY, Kyzzhibek $\mathrm{T}$, Genevois $\mathrm{C}$, et al. $\mathrm{Ba}_{8} \mathrm{CoNb}_{6-x} \mathrm{Ta}_{x} \mathrm{O}_{24}$ eight-layer shifted hexagonal perovskite ceramics with spontaneous $\mathrm{Ta}^{5+}$ ordering and near-zero $\tau_{\mathrm{f}}$. Inorg Chem 2019, 58: 10974-10982.

[333] Sanoj MA, Reshmi CP, Sreena KP, et al. Sinterability and microwave dielectric properties of nano structured $0.95 \mathrm{MgTiO}_{3}-0.05 \mathrm{CaTiO}_{3}$ synthesised by top down and bottom up approaches. J Alloys Compd 2011, 509: 3089-3095.

[334] Rajput SS, Keshri S. Structural, vibrational and microwave dielectric properties of $(1-x) \mathrm{Mg}_{0.95} \mathrm{Co}_{0.05} \mathrm{TiO}_{3}-(x) \mathrm{Ca}_{0.8} \mathrm{Sr}_{0.2} \mathrm{TiO}_{3} \quad$ ceramic composites. J Alloys Compd 2013, 581: 223-229.

[335] Rajput SS, Keshri S, Gupta VR. Microwave dielectric properties of $(1-x) \mathrm{Mg}_{0.95} \mathrm{Zn}_{0.05} \mathrm{TiO}_{3}-(x) \mathrm{Ca}_{0.6} \mathrm{La}_{0.8 / 3} \mathrm{TiO}_{3}$ ceramic composites. J Alloys Compd 2013, 552: 219-226.

[336] Huang JB, Yang B, Yu CY, et al. Microwave and terahertz dielectric properties of $\mathrm{MgTiO}_{3}-\mathrm{CaTiO}_{3}$ ceramics. Mater Lett 2015, 138: 225-227.

[337] Hsu $\mathrm{CH}$, Chang $\mathrm{CH}$. A temperature-stable and high- $Q$ microwave dielectric ceramic of the $\mathrm{MgTiO}_{3}-\left(\mathrm{Ca}_{0.8} \mathrm{Sr}_{0.2}\right)\left(\mathrm{Zr}_{0.1} \mathrm{Ti}_{0.9}\right) \mathrm{O}_{3}$ system. Ceram Int 2015, 41: 6965-6969.

[338] Li LX, Li S, Tian T, et al. Microwave dielectric properties of $(1-x) \mathrm{MgTiO}_{3}-x\left(\mathrm{Ca}_{0.6} \mathrm{Na}_{0.2} \mathrm{Sm}_{0.2}\right) \mathrm{TiO}_{3}$ ceramic system. J Mater Sci: Mater Electron 2016, 27: 1286-1292.

[339] Chen CY, Peng ZJ, Xie LZ, et al. Microwave dielectric properties of novel $(1-x) \mathrm{MgTiO}_{3}-x \mathrm{Ca}_{0.5} \mathrm{Sr}_{0.5} \mathrm{TiO}_{3}$ ceramics. J Mater Sci: Mater Electron 2020, 31: 13696-13703.

[340] Hou GH, Wang ZH, Zhang F. Sintering behavior and microwave dielectric properties of $(1-x) \mathrm{CaTiO}_{3}-x \mathrm{LaAlO}_{3}$ ceramics. J Rare Earths 2011, 29: 160-163.

[341] Liang F, Ni M, Lu WZ, et al. Microwave dielectric properties and crystal structures of $0.7 \mathrm{CaTiO}_{3}-$ $0.3\left[\mathrm{La}_{x} \mathrm{Nd}_{(1-x)}\right] \mathrm{AlO}_{3}$ ceramics. J Alloys Compd 2013, 568: $11-15$.

[342] Li LX, Gao ZD, Liu YR, et al. Influence of $\mathrm{LaAlO}_{3}$ additive to $\mathrm{MgTiO}_{3}-\mathrm{CaTiO}_{3}$ ceramics on sintering behavior and microwave dielectric properties. Mater Lett 2015, 140: 5-8.

[343] $\mathrm{Li} \mathrm{LX}, \mathrm{Li} \mathrm{S}$, Lyu XS, et al. $\mathrm{LaAlO}_{3}$ doped $\left(\mathrm{Mg}_{0.95} \mathrm{Zn}_{0.05}\right) \mathrm{TiO}_{3}-\mathrm{CaTiO}_{3}$ ceramic system with 
ultra-high- $Q$ and temperature-stable characterization. $J$ Mater Sci: Mater Electron 2015, 26: 5871-5876.

[344] Zhang LZ, Lin HX, Zhao XY, et al. Investigation on microwave dielectric properties and microstructures of $(1-x) \mathrm{LaAlO}_{3-x} \mathrm{Ca}_{0.2} \mathrm{Sr}_{0.8} \mathrm{TiO}_{3}$ ceramics. J Alloys Compd 2015, 649: 254-260.

[345] Dou ZM, Jiang J, Wang G, et al. Effect of $\mathrm{Ga}^{3+}$ substitution on the microwave dielectric properties of $0.67 \mathrm{CaTiO}_{3}-$ $0.33 \mathrm{LaAlO}_{3}$ ceramics. Ceram Int 2016, 42: 6743-6748.

[346] Weng MH, Liauh CT, Lin SM, et al. Sintering behaviors, microstructure, and microwave dielectric properties of $\mathrm{CaTiO}_{3}-\mathrm{LaAlO}_{3}$ ceramics using $\mathrm{CuO} / \mathrm{B}_{2} \mathrm{O}_{3}$ additions. Materials 2019, 12: 4187.

[347] Niu ST, Jiang J, Wang JZ, et al. The sintering behavior and microwave dielectric properties of $0.67 \mathrm{CaTiO}_{3}-$ $0.33 \mathrm{LaAlO}_{3}$ ceramics sintered at medium temperatures with the additives of $\mathrm{H}_{3} \mathrm{BO}_{3}-\mathrm{Li}_{2} \mathrm{CO}_{3}$. J Mater Sci: Mater Electron 2020, 31: 14879-14885.

[348] Wang SF, Wang YR, Hsu JC. Densification, microstructural evolution, and dielectric properties of $\mathrm{CaTiO}_{3}-\mathrm{LaGaO}_{3}$ microwave ceramics. J Phys Chem Solids 2011, 72: 1011-1014.

[349] ] Feteira A, Iddles D, Price T, et al. High-permittivity and low-loss microwave dielectric ceramics based on $(x) \mathrm{RE}\left(\mathrm{Zn}_{1 / 2} \mathrm{Ti}_{1 / 2}\right) \mathrm{O}_{3}-(1-x) \mathrm{CaTiO}_{3}(\mathrm{RE}=\mathrm{La}$ and $\mathrm{Nd}) . J \mathrm{Am}$ Ceram Soc 2011, 94: 817-821.

[350] Li LX, Zhang MM, Liao QW, et al. Composite dielectrics $(1-y)\left(\mathrm{Mg}_{1-x} \mathrm{Zn}_{x}\right)_{1.8} \mathrm{Ti}_{1.1} \mathrm{O}_{4}-y \mathrm{CaTiO}_{3}$ suitable for microwave applications. J Alloys Compd 2012, 531: 18-22.

[351] Wang SF, Chen JH, Hsu YF, et al. Effects of $\mathrm{CaTiO}_{3}$ addition on the densification and microwave dielectric properties of $\mathrm{BiSbO}_{4}$ ceramics. Ceram Int 2013, 39: 2857-2861.

[352] Chen YC, Yao SL. Influence of $\mathrm{Ca}_{0.8} \mathrm{Sr}_{0.2} \mathrm{TiO}_{3}$ on the microstructures and microwave dielectric properties of $\mathrm{Nd}\left(\mathrm{Mg}_{0.4} \mathrm{Zn}_{0.1} \mathrm{Sn}_{0.5}\right) \mathrm{O}_{3}$ ceramics. J Mater Sci: Mater Electron 2012, 23: 825-831.

[353] Yang XY, Wang XH, Yao GF, et al. Phase structures and microwave dielectric properties of $x \mathrm{CaTiO}_{3}-(1-x) \mathrm{Sm}_{0.9} \mathrm{Nd}_{0.1} \mathrm{AlO}_{3}$ ceramics. J Mater Sci: Mater Electron 2013, 24: 4662-4668.

[354] Xu P, Yang J, Li JM, et al. Microstructure and microwave dielectric properties of $(1-x) \mathrm{Ca}_{0.6} \mathrm{La}_{0.267} \mathrm{TiO}_{3-x} \mathrm{Ca}\left(\mathrm{Mg}_{1 / 3} \mathrm{Nb}_{2 / 3}\right) \mathrm{O}_{3}$ ceramics. Ceram Int 2012, 38: 3863-3867.

[355] Li JM, Han YX, Qiu T, et al. Effect of bond valence on microwave dielectric properties of $(1-x) \mathrm{CaTiO}_{3-x}\left(\mathrm{Li}_{0.5} \mathrm{La}_{0.5}\right) \mathrm{TiO}_{3}$ ceramics. Mater Res Bull 2012, 47: 2375-2379.

[356] Wang XC, Liu YW, Wang XH, et al. High permittivity and near-zero $\tau \varepsilon$ dielectrics $\mathrm{Ca}_{0.36} \mathrm{Sr}_{0.64} \mathrm{TiO}_{3}-\mathrm{Li}_{0.5} \mathrm{Nd}_{0.5} \mathrm{TiO}_{3}$ for multilayer ceramic capacitors. Jpn J Appl Phys 2015, 54: 111501.

[357] Ning FF, Gan L, Yuan SF, et al. Correlation between vibrational modes of A-site ions and microwave dielectric properties in $(1-x) \mathrm{CaTiO}_{3}-x\left(\mathrm{Li}_{0.5} \mathrm{Sm}_{0.5}\right) \mathrm{TiO}_{3}$ ceramics. $J$
Alloys Compd 2017, 729: 742-748.

[358] Yang XY, Wang XH, Huang M, et al. Synthesis and characterization of $\mathrm{CaTiO}_{3}-(\mathrm{Sm}, \mathrm{Nd}) \mathrm{AlO}_{3}$ microwave ceramics via sol-gel method. J Sol Gel Sci Technol 2014, 69: 61-66.

[359] Qu JJ, Huang DL, Wei X, et al. Effect of $\mathrm{NdAlO}_{3}$ on microstructure, dielectric properties and temperaturestable mechanism of $(\mathrm{Sr}, \mathrm{Ca}, \mathrm{Nd}) \mathrm{TiO}_{3}$ ceramics at microwave frequency. J Mater Sci: Mater Electron 2016, 27: 11110-11117.

[360] Qu JJ, Liu F, Wei X, et al. Sintering behaviour and microwave dielectric properties of a new complex perovskite: $\quad(1-x)\left(\mathrm{Sr}_{0.3} \mathrm{Ca}_{0.427} \mathrm{Nd}_{0.182}\right) \mathrm{TiO}_{3}-x \mathrm{SmAlO}_{3}$ ceramics. Bull Mater Sci 2016, 39: 1645-1649.

[361] Zhang LM, Chang Y, Xin M, et al. Synthesis of $0.65 \mathrm{CaTiO}_{3}-0.35 \mathrm{SmAlO}_{3}$ ceramics and effects of $\mathrm{La}_{2} \mathrm{O}_{3} / \mathrm{SrO}$ doping on their microwave dielectric properties. J Mater Sci: Mater Electron 2018, 29: 21205-21212.

[362] Yang XY, Zhang CY, Wu HY, et al. Structure and microwave dielectric properties of $\mathrm{CaSmAlO}_{4}-\mathrm{CaTiO}_{3}-$ $\mathrm{Sm}_{0.9} \mathrm{Nd}_{0.1} \mathrm{AlO}_{3}$ ceramics with medium to high permittivity. J Ceram Soc Jpn 2020, 128: 756-760.

[363] Zhang LX, Gan L, Cheng HY, et al. Crystal structure, Raman spectra analysis and microwave dielectric properties optimization of $\left(\mathrm{Ca}_{0.22} \mathrm{Li}_{0.39} \mathrm{Sm}_{0.39}\right) \mathrm{TiO}_{3}$ ceramics doped with $\mathrm{SmAlO}_{3}$. J Alloys Compd 2020, 817: 152708 .

[364] Zhou SC, Luan XW, Hu S, et al. Sintering behavior, phase structure and microwave dielectric properties of $\mathrm{CeO}_{2}$ added $\mathrm{CaTiO}_{3}-\mathrm{SmAlO}_{3}$ ceramics prepared by reaction sintering method. Ceram Int 2021, 47: 3741-3746.

[365] Chen YC, You HM. Tuning the microwave dielectric properties of $\mathrm{Zn}_{2} \mathrm{SnO}_{4}$ ceramics by adding $\mathrm{Ca}_{0.8} \mathrm{Sr}_{0.2} \mathrm{TiO}_{3}$. Ceram Int 2015, 41: 9521-9526.

[366] Huang CL, Chien YH, Shih CF, et al. Crystal structure and dielectric properties of $x \mathrm{Ca}\left(\mathrm{Mg}_{1 / 3} \mathrm{Nb}_{2 / 3}\right) \mathrm{O}_{3}-$ $(1-x)\left(\mathrm{Ca}_{0.61} \mathrm{Nd}_{0.26}\right) \mathrm{TiO}_{3}$ at the microwave frequency. Mater Res Bull 2015, 63: 1-5.

[367] Yang XY, Wang XH, Li LT. Effect of $\mathrm{MgO}$ on microstructure and microwave dielectric properties of $0.84 \mathrm{CaTiO}_{3}-0.16 \mathrm{Sm}_{0.9} \mathrm{Nd}_{0.1} \mathrm{AlO}_{3}$ ceramics. Mater Res Bull 2015, 67: 226-229.

[368] Reda AE, Ibrahim DM, Aziz DAA. Microwave dielectric properties of $(1-x) \mathrm{CaTiO}_{3}-x\left(\mathrm{Na}_{0.5} \mathrm{Nd}_{0.5}\right) \mathrm{TiO}_{3}$ ceramics. $J$ Ceram Sci Tech 2016, 7: 243-248.

[369] Lin SH, Chen YB. Structure and characterization of $\mathrm{B}_{2} \mathrm{O}_{3}$ modified $y \mathrm{Nd}\left(\mathrm{Mg}_{1 / 2} \mathrm{Ti}_{1 / 2}\right) \mathrm{O}_{3}-(1-y) \mathrm{Ca}_{0} .8 \mathrm{Sr}_{0.2} \mathrm{TiO}_{3}$ ceramics with a near-zero temperature coefficient at microwave frequency. Ceram Int 2017, 43: 2368-2371.

[370] Yang SW, Liang BL, Liu CH, et al. Microwave sintering and microwave dielectric properties of $(1-x) \mathrm{Ca}_{0.61} \mathrm{La}_{0.26} \mathrm{TiO}_{3-x} \mathrm{Nd}\left(\mathrm{Mg}_{0.5} \mathrm{Ti}_{0.5}\right) \mathrm{O}_{3} \quad$ ceramics. Materials 2021, 14: 438.

[371] Meng LF, Yuan CL, Liu X, et al. Electrical microstructures of $\mathrm{CaTiO}_{3}-\mathrm{Bi}_{0.5} \mathrm{Na}_{0.5} \mathrm{TiO}_{3}$ microwave ceramics with high 
permittivity $\left(\varepsilon_{\mathrm{r}}^{\max } \sim 487\right)$. J Alloys Compd 2019, 803: 850-859.

[372] Zhou XJ, Zhou HF, Luan XW, et al. Structure and dielectric properties of novel series of $3 \mathrm{CaO}-\mathrm{RE}_{2} \mathrm{O}_{3}-$ $2 \mathrm{WO}_{3}(\mathrm{RE}=\mathrm{La}, \mathrm{Nd}$ and $\mathrm{Sm})$ microwave ceramics and the adjustment of $\tau_{\mathrm{f}}$ value. J Mater Sci: Mater Electron 2020, 31: 14953-14960.

[373] Zhang $\mathrm{XH}$, Chang $\mathrm{N}$, Zhang J, et al. Low-loss $(1-x) \mathrm{Ba}_{0.6} \mathrm{Sr}_{0.4} \mathrm{La}_{4} \mathrm{Ti}_{4} \mathrm{O}_{15}-x \mathrm{CaTiO}_{3}$ microwave dielectric ceramics with medium permittivity. J Alloys Compd 2020, 819: 153011.

[374] Zhou XJ, Wang KG, Hu S, et al. Preparation, structure and microwave dielectric properties of novel $\mathrm{La}_{2} \mathrm{MgGeO}_{6}$ ceramics with hexagonal structure and adjustment of its $\tau_{\mathrm{f}}$ value. Ceram Int 2021, 47: 7783-7789.

[375] Hsu CH, Chang CH. Microwave dielectric properties of $\left(\mathrm{Ca}_{0.8} \mathrm{Sr}_{0.2}\right)\left(\mathrm{Sn}_{x} \mathrm{Ti}_{1-x}\right) \mathrm{O}_{3}$ ceramics. Mater Sci Eng: B 2013, 178: $354-357$.

[376] Ravi GA, Azough F, Freer R. Structure and microwave dielectric properties of $\mathrm{Ca}_{0.7} \mathrm{Ti}_{0.7} \mathrm{La}_{0.3}\left(\mathrm{Al}_{0.3-x} \mathrm{Ga}_{x}\right) \mathrm{O}_{3}$ ceramics. Adv Appl Ceram 2012, 111: 398-403.

[377] Lowndes R, Azough F, Cernik R, et al. Structures and microwave dielectric properties of $\mathrm{Ca}_{(1-x)} \mathrm{Nd}_{2 x / 3} \mathrm{TiO}_{3}$ ceramics. J Eur Ceram Soc 2012, 32: 3791-3799.

[378] Li JM, Qiu T. Microwave sintering of $\mathrm{Ca}_{0.6} \mathrm{La}_{0.2667} \mathrm{TiO}_{3}$ microwave dielectric ceramics. Int J Miner Metall Mater 2012, 19: 245-251.

[379] Iqbal Y, Muhammad R. Phase, microstructure and microwave dielectric properties of $\mathrm{Nb}$ and $\mathrm{Ga}$ doped $\mathrm{Ca}_{0.6} \mathrm{La}_{0.267} \mathrm{TiO}_{3}$ ceramics. J Mater Sci: Mater Electron 2015, 26: 10119-10122.

[380] Zhou CR, Chen GH, Cen ZY, et al. Structure and microwave dielectric characteristics of lithium-excess $\mathrm{Ca}_{0.6} \mathrm{Nd}_{0.8 / 3} \mathrm{TiO}_{3} /\left(\mathrm{Li}_{0.5} \mathrm{Nd}_{0.5}\right) \mathrm{TiO}_{3}$ ceramics. Mater Res Bull 2013, 48: 4924-4929.

[381] Hsu CH, Tsai PS, Tseng CF, et al. Microwave dielectric properties of $\mathrm{Ca}_{0.4-x} \mathrm{Mg}_{x} \mathrm{Sm}_{0.4} \mathrm{TiO}_{3}$ ceramics. $J$ Alloys Compd 2014, 582: 355-359.

[382] Muhammad R, Iqbal Y. Microwave dielectric properties of $\mathrm{CaTi}_{1-x}\left(\mathrm{Nb}_{0.5} \mathrm{Ga}_{0.5}\right)_{x} \mathrm{O}_{3}$ ceramics. Mater Lett 2015, 153: 121-123.

[383] Xu Y, Fu RL, Agathopoulos S, et al. Sintering behavior, microstructure, and microwave dielectric properties of $\mathrm{Ca}_{0.66} \mathrm{Ti}_{0.66} \mathrm{Sm}_{0.34} \mathrm{Al}_{0.34} \mathrm{O}_{3}$ ceramics. Ceram Int 2016, 42 : 19036-19041.

[384] Xu Y, Fu RL, Zhao P, et al. Sintering behavior, microwave dielectric properties of $\mathrm{Ca}_{0.66} \mathrm{Ti}_{0.66} \mathrm{Nd}_{0.34} \mathrm{Al}_{0.34} \mathrm{O}_{3}$ ceramics revealed by microstructure and Raman scattering. J Alloys Compd 2019, 785: 335-342.

[385] Chen GH, Chen JS, Kang XL, et al. Structural and microwave dielectric properties of new $\mathrm{CaTi}_{1-x}\left(\mathrm{Al}_{0.5} \mathrm{Nb}_{0.5}\right)_{x} \mathrm{O}_{3}$ thermally stable ceramics. $J$ Alloys Compd 2016, 675: 301-305.

[386] Hameed I, Liu XQ, Li L, et al. Structure evolution and improved microwave dielectric characteristics in
$\mathrm{CaTi}_{1-x}\left(\mathrm{Al}_{0.5} \mathrm{Nb}_{0.5}\right)_{x} \mathrm{O}_{3}$ ceramics. J Alloys Compd 2020, 845: 155435.

[387] Yan YX, Li ZM, Zhang ML, et al. Preparation and microwave dielectric properties of $\mathrm{Ca}_{0.6} \mathrm{La}_{0.8 / 3}\left(\mathrm{Sn}_{x} \mathrm{Ti}_{1-x}\right) \mathrm{O}_{3}$ ceramics. Ceram Int 2017, 43: 8534-8537.

[388] Wang $\mathrm{XH}, \mathrm{Mu} \mathrm{ML}$, Jiang $\mathrm{H}$, et al. Investigation on structure and microwave dielectric properties of novel high dielectric constant $\mathrm{Ca}_{1-3 x / 2} \mathrm{Ce}_{x} \mathrm{TiO}_{3}$ ceramics sintered in nitrogen atmosphere. J Mater Sci: Mater Electron 2019, 30: $1591-1599$.

[389] Liu S, Tang B, Zhou MK, et al. Microwave dielectric characteristics of high permittivity $\mathrm{Ca}_{0.35} \mathrm{Li}_{0.25} \mathrm{Nd}_{0.35} \mathrm{Ti}_{1-x}\left(\mathrm{Zn}_{1 / 3} \mathrm{Ta}_{2 / 3}\right)_{x} \mathrm{O}_{3} \quad$ ceramics $\quad(x=$ 0.00-0.12). Ceram Int 2019, 45: 8600-8606.

[390] Xiong Z, Tang B, Luo FC, et al. Characterization of structure, chemical bond and microwave dielectric properties in $\mathrm{Ca}_{0.61} \mathrm{Nd}_{0.26} \mathrm{TiO}_{3}$ ceramic substituted by chromium for titanium. J Alloys Compd 2020, 835: 155249.

[391] Shi L, Peng R, Zhang HW, et al. Effects of Magnesiumtungsten co-substitution on crystal structure and microwave dielectric properties of $\mathrm{CaTi}_{1-x}\left(\mathrm{Mg}_{1 / 2} \mathrm{~W}_{1 / 2}\right)_{x} \mathrm{O}_{3}$ ceramics. Ceram Int 2021, 47: 3354-3360.

[392] Zaman A, Uddin S, Mehboob N, et al. Structural investigation and improvement of microwave dielectric properties in $\mathrm{Ca}\left(\mathrm{Hf}_{x} \mathrm{Ti}_{1-x}\right) \mathrm{O}_{3}$ ceramics. Phys Scr 2020, 96: 025701.

[393] $\mathrm{Hu} \mathrm{P}$, Jiao $\mathrm{H}$, Wang $\mathrm{CH}$, et al. Influence of thermal treatments on the low frequency conductivity and microwave dielectric loss of $\mathrm{CaTiO}_{3}$ ceramics. Mater Sci Eng: B 2011, 176: 401-405.

[394] Hsu CH, Chang CH. Microwave dielectric properties of new $\left(\mathrm{Ca}_{0.8} \mathrm{Sr}_{0.2}\right) \mathrm{SnO}_{3}$ ceramics. Ceram Int 2012, 38: 4411-4413.

[395] Chen YC, Chen KC, Wu CY. Microwave dielectric properties of $(1-y) \mathrm{Nd}_{1-2 x / 3} \mathrm{Ba}_{x}\left(\mathrm{Mg}_{0.5} \mathrm{Sn}_{0.5}\right) \mathrm{O}_{3}-y \mathrm{Ca}_{0.8} \mathrm{Sr}_{0.2} \mathrm{TiO}_{3}$ ceramic. J Mater Sci: Mater Electron 2013, 24: 819-826.

[396] Shi F, Fu GG, Xiao EC, et al. Lattice vibrational characteristics and dielectric properties of pure phase $\mathrm{CaTiO}_{3}$ ceramic. J Mater Sci: Mater Electron 2020, 31: 18070-18076.

[397] Tian CL, Yue ZX, Zhou YY. Microwave dielectric properties of $\mathrm{Ba}\left[\mathrm{Ti}_{0.4} \mathrm{Ga}_{0.3} \mathrm{Nb}_{0.3}(1-x) \mathrm{Sb}_{0.3 x}\right] \mathrm{O}_{3}$ perovskite ceramics. Mater Res Bull 2013, 48: 455-460.

[398] Liu F, Yuan CL, Liu XY, et al. Effects of structural characteristics on microwave dielectric properties of $\left(\mathrm{Sr}_{0.2} \mathrm{Ca}_{0.488} \mathrm{Nd}_{0.208}\right) \mathrm{Ti}_{1-x} \mathrm{Ga}_{4 x / 3} \mathrm{O}_{3}$ ceramics. Mater Res Bull 2015, 70: 678-683.

[399] Parida S, Rout SK, Subramanian V, et al. Structural, microwave dielectric properties and dielectric resonator antenna studies of $\mathrm{Sr}\left(\mathrm{Zr}_{x} \mathrm{Ti}_{1-x}\right) \mathrm{O}_{3}$ ceramics. $J$ Alloys Compd 2012, 528: 126-134.

[400] Wang JY, Zhou H, Liu JT, et al. Microstructure and dielectric tunable properties of $\mathrm{SrO}\left(\mathrm{Sr}_{1-x} \mathrm{Ba}_{x} \mathrm{TiO}_{3}\right) n$ microwave ceramics. Ceram Int 2012, 38: 3503-3507. 
[401] Zhang MW, Zhai JW, Shen B, et al. Microwave dielectric properties of low loss and highly tunable $\mathrm{Ba}_{0.5} \mathrm{Sr}_{0.5} \mathrm{Ti}_{1-3 y / 2} \mathrm{~W}_{y} \mathrm{O}_{3}$ ceramics. J Mater Res 2012, 27: 910-914.

[402] Zhang JJ, Zhai JW, Wang JY. Structural and dielectric tunable properties of $\mathrm{Ba}_{0.4} \mathrm{Sr}_{0.6} \mathrm{Ti}_{1-y} \mathrm{Si}_{y} \mathrm{O}_{3}$ microwave ceramics. Sci China Technol Sci 2012, 55: 610-615.

[403] Tang LJ, Zhai JW, Shen B, et al. Property optimization of $\mathrm{Ba}_{0.4} \mathrm{Sr}_{0.6} \mathrm{TiO}_{3}-\mathrm{BaMoO}_{4}$ composite ceramics for tunable microwave applications. Ceram Int 2012, 38: 4967-4971.

[404] Tang LJ, Zhai JW, Zhang HJ, et al. Microwave dielectric properties of tunable $\mathrm{Ba}_{0.5} \mathrm{Sr}_{0.5} \mathrm{TiO}_{3}$ and scheelite $\mathrm{AMoO}_{4}$ (A = Ba, Sr) composite ceramics. J Alloys Compd 2013, 551: 556-561.

[405] Tang LJ, Wang JW, Zhai JW, et al. Dielectric tunable properties of $\mathrm{Ba}_{0.5} \mathrm{Sr}_{0.5} \mathrm{TiO}_{3}-\mathrm{MgMoO}_{4}$ composite ceramics for microwave applications. J Mater Sci: Mater Electron 2013, 24: 2576-2580.

[406] Jiang HT, Zhai JW, Zhang MW, et al. Enhanced microwave dielectric properties of $\mathrm{Ba}_{0.40} \mathrm{Sr}_{0.60} \mathrm{TiO}_{3}-$ $\mathrm{Zr}_{0.80} \mathrm{Sn}_{0.20} \mathrm{TiO}_{4}$ composite ceramics. J Mater Sci 2012, 47: 2617-2623.

[407] Zhang QW, Zhai JW, Ben QQ, et al. Enhanced microwave dielectric properties of $\mathrm{Ba}_{0.4} \mathrm{Sr}_{0.6} \mathrm{TiO}_{3}$ ceramics doping by metal Fe powders. J Appl Phys 2012, 112: 104104.

[408] He YY, Zhao JY, Xu YB, et al. Microstructures and dielectric tunable properties of $\mathrm{Ba}_{0.5} \mathrm{Sr}_{0.5} \mathrm{TiO}_{3}-\mathrm{MgO}-$ $\mathrm{Mg}_{2} \mathrm{TiO}_{4}$ composite ceramics. J Mater Sci: Mater Electron 2013, 24: 2372-2378.

[409] He YY, Zhao JY, Xu YB, et al. Anomalous correlation between dielectric constant and tunability in (Ba,Sr) $\mathrm{TiO}_{3}-\mathrm{MgO}-\mathrm{Mg}_{2} \mathrm{SiO}_{4}$ composite ceramics. $\mathrm{J} \mathrm{Am}$ Ceram Soc 2013, 96: 1203-1208.

[410] Liu D, Pu YP, Shi X. Effects of $\mathrm{Bi}_{2} \mathrm{O}_{3}$ and $\mathrm{Cr}_{2} \mathrm{Ti}_{3} \mathrm{O}_{9}$ co-doping on dielectric properties in $\mathrm{BaTiO}_{3}$-based ceramics. Vacuum 2012, 86: 1568-1571.

[411] Hu GX, Gao F, Liu LL, et al. Microstructure and dielectric properties of highly tunable $\mathrm{Ba}_{0.6} \mathrm{Sr}_{0.4} \mathrm{TiO}_{3} / \mathrm{MgO} / \mathrm{Al}_{2} \mathrm{O}_{3} /$ ZnO composite. J Alloys Compd 2012, 518: 44-50.

[412] Jiang K, Zhang JZ, Yu WL, et al. Manganese doping effects on interband electronic transitions, lattice vibrations, and dielectric functions of perovskite-type $\mathrm{Ba}_{0.4} \mathrm{Sr}_{0.6} \mathrm{TiO}_{3}$ ferroelectric ceramics. Appl Phys A 2012, 106: $877-884$.

[413] Tseng CF, Lu SC. Microwave dielectric properties of $\left(\mathrm{Ba}_{0.1} \mathrm{Mg}_{0.9}\right)\left(\mathrm{A}_{0.05} \mathrm{Ti}_{0.95}\right) \mathrm{O}_{3} \quad(\mathrm{~A}=\mathrm{Zr}, \mathrm{Sn})$ ceramics. Ferroelectrics 2013, 451: 76-83.

[414] Liu F, Liu XY, Yuan CL, et al. Microstructures and microwave dielectric properties of $(1-x)\left(\mathrm{Sr}_{0.4} \mathrm{Na}_{0.3} \mathrm{La}_{0.3}\right) \mathrm{TiO}_{3}-x \mathrm{LnAlO}_{3} \quad(\mathrm{Ln}=\mathrm{Sm}, \mathrm{Nd})$ ceramic systems. J Eur Ceram Soc 2015, 35: 2091-2098.

[415] Xie WT, Jiang QX, Cao QL, et al. Effect of $\mathrm{ZnO} / \mathrm{WO}_{3}$ additives on sintering behavior and microwave dielectric properties of $(\mathrm{Sr}, \mathrm{Ca}) \mathrm{TiO}_{3}-(\mathrm{Sm}, \mathrm{Nd}) \mathrm{AlO}_{3}$ ceramics. $J$ Mater Sci: Mater Electron 2018, 29: 9745-9750.
[416] Singh J, Bahel S. Structural and dielectric properties of $\left(\mathrm{Ba}_{x} \mathrm{Mg}_{1-x}\right)\left(\mathrm{Ti}_{0.95} \mathrm{Sn}_{0.05}\right) \mathrm{O}_{3}(x=0.025,0.05,0.075$ and 0.1) solid solutions. J Mater Sci: Mater Electron 2019, 30: 6500-6506.

[417] Ma PP, Liu XQ, Zhang FQ, et al. $\mathrm{Sr}\left(\mathrm{Ga}_{0.5} \mathrm{Nb}_{0.5}\right)_{1-x} \mathrm{Ti}_{x} \mathrm{O}_{3}$ low-loss microwave dielectric ceramics with medium dielectric constant. J Am Ceram Soc 2015, 98: 2534-2540.

[418] Qu JJ, Liu F, Yuan CL, et al. Microwave dielectric properties of $0.2 \mathrm{SrTiO}_{3}-0.8 \mathrm{Ca}_{0.61} \mathrm{Nd}_{0.26} \mathrm{Ti}_{1-x} \mathrm{Al}_{4 x / 3} \mathrm{O}_{3}$ ceramics. Mater Sci Eng: B 2015, 191: 15-20.

[419] Singh J, Bahel S. Synthesis and characterization of temperature stable low-loss $(1-x) \mathrm{Mg}\left(\mathrm{Ti}_{0.95} \mathrm{Sn}_{0.05}\right) \mathrm{O}_{3}-$ $(x) \mathrm{BaTiO}_{3}(0 \leqslant x \leqslant 0.1)$ ceramics for microwave applications. J Mater Sci 2021, 56: 10947-10964.

[420] Ullah B, Lei W, Cao QS, et al. Structure and microwave dielectric behavior of A-site-doped $\mathrm{Sr}_{(1-1.5 x)} \mathrm{Ce}_{x} \mathrm{TiO}_{3}$ ceramics system. J Am Ceram Soc 2016, 99: 3286-3292.

[421] Tian CL, Yue ZX, Meng SQ, et al. Structures and microwave dielectric properties of $\mathrm{Ba}\left[\mathrm{Ti}_{1-x}\left(\mathrm{Co}_{0.5} \mathrm{~W}_{0.5}\right)_{x}\right] \mathrm{O}_{3}$ $(x=0.40-0.90)$ perovskite ceramics. J Am Ceram Soc 2012, 95: 1645-1650.

[422] Tian CL, Yue ZX, Zhou YY, et al. Crystal structures and microwave dielectric properties of $\mathrm{Zn}, \mathrm{W}$ co-substituted $\mathrm{BaTiO}_{3}$ perovskite ceramics. J Solid State Chem 2013, 197: 242-247.

[423] Lin YJ, Wang SF, Chen SH, et al. Microwave dielectric properties of $\left(\mathrm{Ba}_{1-x} \mathrm{Sr}_{x}\right)\left(\mathrm{Mg}_{0.5} \mathrm{~W}_{0.5}\right) \mathrm{O}_{3}$ ceramics. Ceram Int 2015, 41: 8931-8935.

[424] Chen YC, Syu RY. Dielectric properties of $\mathrm{Ba}_{2} \mathrm{Mg}_{0.95} \mathrm{Zn}_{0.05} \mathrm{WO}_{6}$ ceramics at microwave frequency. $J$ Mater Sci: Mater Electron 2016, 27: 6979-6984.

[425] Bian JJ, Wu JY. Structure and microwave dielectric properties of B-site deficient double perovskite- $\mathrm{Ba}\left[\left(\mathrm{Mg}_{(1-x) / 2} \mathrm{Y}_{x / 3} \square_{x / 6}\right) \mathrm{W}_{1 / 2}\right] \mathrm{O}_{3}$. Ceram Int 2016, 42: 3290-3295.

[426] Ullah B, Lei W, Wang XW, et al. Structure instability and high microwave dielectric permittivity of nonstoichiometric $\left(\mathrm{Sr}_{0.4} \mathrm{Ce}_{0.4}\right)_{1-x} \mathrm{Nd}_{x} \mathrm{Ti}_{0.8} \mathrm{Mg}_{0.2} \mathrm{O}_{3}$ system for wireless communication. J Materiomics 2021, 7: 25-33.

[427] Hu X, Huang XJ, Chen YH, et al. Phase evolution and microwave dielectric properties of $\mathrm{SrTiO}_{3}$ added $\mathrm{ZnAl}_{2} \mathrm{O}_{4}-\mathrm{Zn}_{2} \mathrm{SiO}_{4}-\mathrm{SiO}_{2}$ ceramics. Ceram Int 2020, 46: 7050-7054.

[428] Liu F, Qu JJ, Yan HG, et al. Study on phase structures and compositions, microstructures, and dielectric characteristics of $(1-x) \mathrm{NdGaO}_{3-x} \mathrm{Bi}_{0.5} \mathrm{Na}_{0.5} \mathrm{TiO}_{3}$ microwave ceramic systems. Ceram Int 2020, 46: 16185-16195.

[429] Jin X, Guo QH, Bian JJ. Structure and dielectric properties of A-site-deficient perovskite $\mathrm{Nd}_{1-x / 3} \mathrm{M}_{x} \mathrm{NbO}_{3}(\mathrm{M}=\mathrm{Li}, \mathrm{Ag}$; $0 \leqslant x \leqslant 0.20)$ ceramics. J Mater Sci 2012, 47: 6015-6024.

[430] Xiao M, Zhang QQ, Jia CR. The microstructure and properties of $\mathrm{Ag}\left(\mathrm{Nb}_{0.8} \mathrm{Ta}_{0.2}\right)_{1-x}\left(\mathrm{Mn}_{0.5} \mathrm{~W}_{0.5}\right)_{x} \mathrm{O}_{3}$ ceramic system. J Wuhan Univ Technol Mater Sci Ed 2012, 27: 
735-739.

[431] Peng Y, Li LX, Cao LF, et al. Correlation between crystal structure and properties of ultra-high dielectric constant ceramics $x \mathrm{SrCO}_{3}-\mathrm{Bi}_{2} \mathrm{O}_{3}-\mathrm{Ag}(\mathrm{Nb}, \mathrm{Ta}) \mathrm{O}_{3}$. J Electroceramics 2012, 28: 209-213.

[432] Saleem M, Iqbal Y, Qin S, et al. Phase, microstructure and microwave dielectric properties of A-site deficient $(\mathrm{La}, \mathrm{Nd})_{2 / 3} \mathrm{TiO}_{3}$ perovskite ceramics. Mater Sci Pol 2015, 33: 126-130.

[433] Zhang MM, Li LX, Xia WS, et al. Structure and properties analysis for $\mathrm{MgTiO}_{3}$ and $\left(\mathrm{Mg}_{0.97} \mathrm{M}_{0.03}\right) \mathrm{TiO}_{3}(\mathrm{M}=\mathrm{Ni}, \mathrm{Zn}$, $\mathrm{Co}$ and $\mathrm{Mn})$ microwave dielectric materials. J Alloys Compd 2012, 537: 76-79.

[434] Gogoi P, Sharma P, Pamu D. Microwave and broadband dielectric properties of $\mathrm{Ni}$ substituted $\mathrm{MgTiO}_{3}$ ceramics. $J$ Mater Sci: Mater Electron 2016, 27: 9052-9060.

[435] Gogoi P, Singh LR, Pamu D. Characterization of Zn doped $\mathrm{MgTiO}_{3}$ ceramics: An approach for RF capacitor applications. J Mater Sci: Mater Electron 2017, 28: 11712-11721.

[436] Lin SH, Chen YB. Low dielectric loss characteristics of $\left[\left(\mathrm{Mg}_{1-x} \mathrm{Zn}_{x}\right)_{0.95} \mathrm{Co}_{0.05}\right]_{1.02} \mathrm{TiO}_{3.02}$ ceramics at microwave frequencies. J Mater Sci: Mater Electron 2017, 28: 4154-4160.

[437] Li LX, Ding X, Liao QW. Structure and properties analysis for low-loss $\left(\mathrm{Mg}_{1-x} \mathrm{Co}_{x}\right) \mathrm{TiO}_{3}$ microwave dielectric materials prepared by reaction-sintering method. Ceram Int 2012, 38: 1937-1941.

[438] Gangwar RK, Singh SP, Choudhary M, et al. Microwave dielectric properties of $\left(\mathrm{Zn}_{1-x} \mathrm{Mg}_{x}\right) \mathrm{TiO}_{3}$ (ZMT) ceramics for dielectric resonator antenna application. J Alloys Compd 2011, 509: 10195-10202.

[439] Yu HT, Xue XM, Xu GL. Correlation between Sn substitution for Ti and microwave dielectric properties of magnesium titanate ceramics. Int J Appl Ceram Technol 2013, 10: E186-E191.

[440] Santhosh Kumar T, Gogoi P, Perumal A, et al. Effect of cobalt doping on the structural, microstructure and microwave dielectric properties of $\mathrm{MgTiO}_{3}$ ceramics prepared by semi alkoxide precursor method. J Am Ceram Soc 2014, 97: 1054-1059.

[441] Gong ZJ, Wang ZF, Wang LX, et al. Microwave dielectric properties of high- $Q \mathrm{Mg}\left(\mathrm{Sn}_{x} \mathrm{Ti}_{1-x}\right) \mathrm{O}_{3}$ ceramics. Electron Mater Lett 2013, 9: 331-335.

[442] Jia XB, Xu Y, Zhao P, et al. Structural dependence of microwave dielectric properties in ilmenite-type $\mathrm{Mg}\left(\mathrm{Ti}_{1-x} \mathrm{Nb}\right) \mathrm{O}_{3}$ solid solutions by Rietveld refinement and Raman spectra. Ceram Int 2021, 47: 4820-4830.

[443] Wu HT, Jiang YS, Cui YJ, et al. Improvements in the sintering behavior and microwave dielectric properties of geikielite-type $\mathrm{MgTiO}_{3}$ ceramics. J Electron Mater 2013, 42: 445-451.

[444] Wang HP, Yang QH, Li DH, et al. Sintering behavior and microwave dielectric properties of $\mathrm{MgTiO}_{3}$ ceramics doped with $\mathrm{B}_{2} \mathrm{O}_{3}$ by sol-gel method. J Mater Sci Technol
2012, 28: 751-755.

[445] Tseng CF, Lu SC. Influence of $\mathrm{SrTiO}_{3}$ modification on dielectric properties of $\mathrm{Mg}\left(\mathrm{Zr}_{0.05} \mathrm{Ti}_{0.95}\right) \mathrm{O}_{3}$ ceramics at microwave frequency. Mater Sci Eng: B 2013, 178: 358-362.

[446] Yu HT, Cheng JL, Zhang WB, et al. Microwave dielectric properties of $\mathrm{Mg}\left(\mathrm{Zr}_{0.05} \mathrm{Ti}_{0.95}\right) \mathrm{O}_{3}-\mathrm{SrTiO}_{3}$ ceramics. J Mater Sci: Mater Electron 2012, 23: 572-575.

[447] Xue XM, Yu HT, Xu GL. Phase composition and microwave dielectric properties of $\mathrm{Mg}$-excess $\mathrm{MgTiO}_{3}$ ceramics. J Mater Sci: Mater Electron 2013, 24: $1287-1291$.

[448] Huang CL, Huang SH. Low-loss microwave dielectric ceramics in the $\left(\mathrm{Co}_{1-x} \mathrm{Zn}_{x}\right) \mathrm{TiO}_{3}(x=0-0.1)$ system. $J$ Alloys Compd 2012, 515: 8-11.

[449] Liou YC, Yang SL, Chu SY. Effects of $\mathrm{MgO}$ and $\mathrm{Mg}(\mathrm{OH})_{2}$ on phase formation and properties of strontium-doped $\mathrm{MgTiO}_{3}$ microwave dielectric ceramics. J Alloys Compd 2013, 576: 161-169.

[450] Li H, Tang B, Li YX, et al. Effects of $\mathrm{Mg}_{2.05} \mathrm{SiO}_{4.05}$ addition on phase structure and microwave properties of $\mathrm{MgTiO}_{3}-\mathrm{CaTiO}_{3}$ ceramic system. Mater Lett 2015, 145: 30-33.

[451] Tang B, Li YX, Li H, et al. Structure and microwave dielectric properties of $\left(\mathrm{Zn}_{0.3} \mathrm{Co}_{0.7}\right) \mathrm{Ti}_{1-x} \mathrm{Sn}_{x} \mathrm{O}_{3}$ ceramics. $J$ Mater Sci: Mater Electron 2015, 26: 2795-2799.

[452] Huang XP, Liu F, Yuan CL, et al. Microstructures and microwave dielectric properties of $\mathrm{Mg}_{n+1} \mathrm{TinO}_{3 n+1}$ ceramics with ultralow dielectric loss. Mater Lett 2016, 185: 432-435.

[453] Chen CY, Peng ZJ, Xie LZ, et al. Effects of adding $\mathrm{B}_{2} \mathrm{O}_{3}$ on microwave dielectric properties of $0.9625 \mathrm{MgTiO}_{3}-$ $0.0375\left(\mathrm{Ca}_{0.5} \mathrm{Sr}_{0.5}\right) \mathrm{TiO}_{3}$ composite ceramics. Int $J$ Appl Ceram Technol 2020, 17: 2545-2552.

[454] Yu T, Luo T, Yang QH, et al. Ultra-high quality factor of $\mathrm{Mg}_{6} \mathrm{Ti}_{5} \mathrm{O}_{16}$-based microwave dielectric ceramics with temperature stability. J Mater Sci: Mater Electron 2021, 32: 2547-2556.

[455] Chen KC, Chen YC, Chen MD. Microwave dielectric properties of $\mathrm{Mg}_{1 / 3} \mathrm{Nb}_{2 / 3} \mathrm{SnO}_{4}$ ceramics. Ferroelectr Lett Sect 2012, 39: 1-7.

[456] Bhuyan RK, Kumar TS, Pamu D, et al. Structural and microwave dielectric properties of $\mathrm{Mg}_{2} \mathrm{TiO}_{4}$ ceramics synthesized by mechanical method. Int J Appl Ceram Technol 2013, 10: E18-E24.

[457] Bhuyan RK, Kumar TS, Goswami D, et al. Liquid phase effect of $\mathrm{La}_{2} \mathrm{O}_{3}$ and $\mathrm{V}_{2} \mathrm{O}_{5}$ on microwave dielectric properties of $\mathrm{Mg}_{2} \mathrm{TiO}_{4}$ ceramics. J Electroceramics 2013, 31: 48-54.

[458] Bhuyan RK, Kumar TS, Goswami D, et al. Enhanced densification and microwave dielectric properties of $\mathrm{Mg}_{2} \mathrm{TiO}_{4}$ ceramics added with $\mathrm{CeO}_{2}$ nanoparticles. Mater Sci Eng: B 2013, 178: 471-476.

[459] Huang CL, Tseng YW, Chen JY, et al. Dielectric properties of high- $Q\left(\mathrm{Mg}_{1-x} \mathrm{Zn}_{x}\right)_{1.8} \mathrm{Ti}_{1.1} \mathrm{O}_{4}$ ceramics at microwave 
frequency. J Eur Ceram Soc 2012, 32: 2365-2371.

[460] Chen YB. Dielectric properties and crystal structure of $\mathrm{Mg}_{2} \mathrm{TiO}_{4}$ ceramics substituting $\mathrm{Mg}^{2+}$ with $\mathrm{Zn}^{2+}$ and $\mathrm{Co}^{2+} . J$ Alloys Compd 2012, 513: 481-486.

[461] Cheng L, Liu P, Qu SX, et al. Microwave dielectric properties of $\mathrm{Mg}_{2} \mathrm{TiO}_{4}$ ceramics synthesized via high energy ball milling method. J Alloys Compd 2015, 623: 238-242.

[462] Lyu XS, Li LX, Sun H, et al. A novel low-loss spinel microwave dielectric ceramic $\mathrm{CoZnTiO}_{4}$. J Mater Sci: Mater Electron 2015, 26: 8663-8666.

[463] Li H, Tang B, Li YX, et al. Relationships between Sn substitution for Ti and microwave dielectric properties of $\mathrm{Mg}_{2}\left(\mathrm{Ti}_{1-x} \mathrm{Sn}_{x}\right) \mathrm{O}_{4}$ ceramics system. J Mater Sci: Mater Electron 2015, 26: 571-577.

[464] Chen YC, Syu RY. Enhancement quality factor of $\mathrm{ZnNiTiO}_{4}$ microwave ceramics by substituting $\mathrm{Ti}^{4+}$ with $\mathrm{Sn}^{4+}$. J Mater Sci: Mater Electron 2017, 28: 673-678.

[465] Chen YC, Syu RY. Elucidating the microstructures and microwave dielectric properties of $\mathrm{ZnNiTiO}_{4}$ ceramics. $J$ Mater Sci: Mater Electron 2016, 27: 8356-8362.

[466] Li H, Xiang $\mathrm{R}$, Chen XQ, et al. Intrinsic dielectric behavior of $\mathrm{Mg}_{2} \mathrm{TiO}_{4}$ spinel ceramic. Ceram Int 2020, 46: 4235-4239.

[467] Xiang R, Li H, Zhang PC, et al. Crystal structure and microwave dielectric properties of $\mathrm{Mg}_{2} \mathrm{Ti}_{1-x} \mathrm{Ga}_{4 / 3 x} \mathrm{O}_{4}$ $(0.05 \leqslant x \leqslant 0.13)$ ceramics. Ceram Int 2021, 47: 84478452.

[468] Fang ZX, Tang B, Li YX, et al. Microstructures and microwave dielectric properties of $\mathrm{Na}_{0.5} \mathrm{Nd}_{0.2} \mathrm{Sm}_{0.3} \mathrm{Ti}_{1-x} \mathrm{Sn}_{x} \mathrm{O}_{3}$ ceramics $(x=0.00$ to 0.50$)$. $J$ Electron Mater 2015, 44: 4236-4242.

[469] Zhou L, Tang B, Zhang SR. Influence of Sn-substitution on microstructure and microwave dielectric properties of $\mathrm{Na}_{1 / 2} \mathrm{Nd}_{1 / 2} \mathrm{TiO}_{3}$ ceramics. J Mater Sci: Mater Electron 2015, 26: 424-428.

[470] Fang ZX, Tang B, Si F, et al. Effects of Zr-substitution on microwave dielectric properties of $\mathrm{Na}_{0.5} \mathrm{Nd}_{0.2} \mathrm{Sm}_{0.3} \mathrm{Ti}_{1-x} \mathrm{Zr}_{x} \mathrm{O}_{3}$ ceramics $(x=0.00-0.30) . J$ Electron Mater 2016, 45: 5198-5205.

[471] Fang ZX, Tang B, Zhang SR. Microwave dielectric properties of $\mathrm{Na}_{1 / 2} \mathrm{Sm}_{1 / 2} \mathrm{Ti}_{1-x}\left(\mathrm{Cr}_{1 / 2} \mathrm{Nb}_{1 / 2}\right)_{x} \mathrm{O}_{3}$ Ceramics $(x=$ 0-0.025). IOP Conf Ser: Mater Sci Eng 2017, 170: 012029 .

[472] Gan L, An SB, Yuan SF, et al. Sintering characteristics and microwave dielectric properties of $(1-x) \mathrm{Li}_{0.5} \mathrm{Sm}_{0.5} \mathrm{TiO}_{3}-x \mathrm{Na}_{0.5} \mathrm{Sm}_{0.5} \mathrm{TiO}_{3}$ ( $x=0.35$ to 0.45$)$ ceramics. J Electron Mater 2019, 48: 3624-3630.

[473] Zhou YY, Tian CL, Meng SQ, et al. Structural transitions and microwave dielectric properties of $\mathrm{Ba}_{2-2 x} \mathrm{Sr}_{2 x} \mathrm{SmSbO}_{6}$ double perovskites. J Am Ceram Soc 2012, 95: 16651670 .

[474] Wu JY, Bian JJ. Structure stability and microwave dielectric properties of double perovskite ceramics $-\mathrm{Ba}_{2} \mathrm{Mg}_{1-x} \mathrm{Ca}_{x} \mathrm{WO}_{6}(0.0 \leqslant x \leqslant 0.15)$. Ceram Int
2012, 38: 3217-3225.

[475] Chen YC, Wang YN, Syu RY. Effect of sintering temperature on microstructures and microwave dielectric properties of $\mathrm{Ba}_{2} \mathrm{MgWO}_{6}$ ceramics. J Mater Sci: Mater Electron 2016, 27: 4259-4264.

[476] Diao CL, Wang CH, Luo NN, et al. First-principle calculation and assignment for vibrational spectra of $\mathrm{Ba}\left(\mathrm{Mg}_{1 / 2} \mathrm{~W}_{1 / 2}\right) \mathrm{O}_{3}$ microwave dielectric ceramic. $J \mathrm{Am}$ Ceram Soc 2013, 96: 2898-2905.

[477] Li L, Zhang W, Chen XM, et al. Dielectric properties of $\mathrm{CaCu}_{3} \mathrm{Ti}_{4} \mathrm{O}_{12}, \mathrm{Ba}\left(\mathrm{Fe}_{1 / 2} \mathrm{Nb}_{1 / 2}\right) \mathrm{O}_{3}$, and $\mathrm{Sr}\left(\mathrm{Fe}_{1 / 2} \mathrm{Nb}_{1 / 2}\right) \mathrm{O}_{3}$ giant permittivity ceramics at microwave frequencies. $J$ Appl Phys 2012, 111: 064108.

[478] Tay KW, Fu YP, Huang JF, et al. Effect of $\mathrm{Bi}_{2} \mathrm{O}_{3}$ and $\mathrm{B}_{2} \mathrm{O}_{3}$ additives on the sintering temperature, microstructure, and microwave dielectric properties for $\mathrm{Sm}\left(\mathrm{Mg}_{0.5} \mathrm{Ti}_{0.5}\right) \mathrm{O}_{3}$ ceramics. Ceram Int 2011, 37: 1025-1031.

[479] Chen YB. New dielectric material system of $\mathrm{Nd}\left(\mathrm{Mg}_{1 / 2} \mathrm{Ti}_{1 / 2}\right) \mathrm{O}_{3}-\mathrm{SrTiO}_{3}$ in the microwave frequency range. J Alloys Compd 2011, 509: 2285-2288.

[480] Chen YC. Improving microwave dielectric properties of $\mathrm{La}_{2.98 / 3} \mathrm{Sr}_{0.01}\left(\mathrm{Mg}_{0.5} \mathrm{Sn}_{0.5}\right) \mathrm{O}_{3}$ ceramics with $\mathrm{CuO}$ additive. Curr Appl Phys 2012, 12: 483-488.

[481] Hsu CH, Chang $\mathrm{CH}$. Microwave dielectric properties of $\mathrm{Nd}\left(\mathrm{Zn}_{1 / 2} \mathrm{Ti}_{1 / 2}\right) \mathrm{O}_{3}$ ceramics with $\mathrm{V}_{2} \mathrm{O}_{5}$ additives. $J$ Mater Eng Perform 2013, 22: 312-315.

[482] Chen YY, Chen YC, Liu HX, et al. Effect of Sm substitution on microwave dielectric properties of $\mathrm{Nd}\left(\mathrm{Mg}_{0.5} \mathrm{Sn}_{0.5}\right) \mathrm{O}_{3}$ ceramics. J Mater Sci: Mater Electron 2013, 24: 4600-4606.

[483] Chen YC, Yao SL, Wu CY. Microwave dielectric properties and microstructures of $\mathrm{Nd}\left(\mathrm{Mg}_{0.5-x} \mathrm{Co}_{x} \mathrm{Sn}_{0.5}\right) \mathrm{O}_{3}$ ceramics. J Mater Sci: Mater Electron 2012, 23: 13201326.

[484] Wang YN. Enhancing the microwave dielectric properties of $\mathrm{Nd}\left(\mathrm{Mg}_{0.5} \mathrm{Sn}_{0.5}\right) \mathrm{O}_{3}$ ceramics by substituting $\mathrm{Nd}^{3+}$ with $\mathrm{Ca}^{2+}$. J Mater Sci: Mater Electron 2013, 24: 4510-4515.

[485] Chen YC, Wu CY. Effect of $\mathrm{Sr}$ substitution on microwave dielectric properties of $\mathrm{Nd}\left(\mathrm{Mg}_{0.5} \mathrm{Sn}_{0.5}\right) \mathrm{O}_{3}$ ceramics. Ceram Int 2013, 39: 1877-1883.

[486] Chen YC, Weng MZ, Chen YY. Influence of $\mathrm{Ba}^{2+}$ substitution on the microwave dielectric properties of $\mathrm{Nd}\left(\mathrm{Mg}_{0.5} \mathrm{Sn}_{0.5}\right) \mathrm{O}_{3}$ ceramics. J Mater Sci: Mater Electron 2013, 24: 2970-2975.

[487] Chen YC, Chen YY, Yao SL. Improved microwave dielectric properties of $\mathrm{Nd}\left(\mathrm{Mg}_{0.5} \mathrm{Sn}_{0.5}\right) \mathrm{O}_{3}$ ceramics with $\mathrm{Ni}^{2+}$ substituting. J Mater Sci: Mater Electron 2013, 24: 1150-1157.

[488] Chen YC, Chang KC, Yao SL. Improved microwave dielectric properties of $\mathrm{Nd}\left(\mathrm{Mg}_{0.5} \mathrm{Sn}_{0.5}\right) \mathrm{O}_{3}$ ceramics by substituting $\mathrm{Mg}^{2+}$ with $\mathrm{Zn}^{2+}$. Ceram Int 2012, 38: 5377-5383.

[489] Chen YC, Tsai RJ, Wu CY. Microwave dielectric properties and microstructures of $\mathrm{Nd}\left(\mathrm{Mg}_{0.5} \mathrm{Sn}_{0.5-x} \mathrm{Ti}_{x}\right) \mathrm{O}_{3}$ ceramics. Ceram Int 2012, 38: 2927-2934. 
[490] Chen YC, Chang KC, Tsai DY. A hybrid dielectric resonator antenna based upon novel complex perovskite microwave ceramic. Ceram Int 2013, 39: 8043-8048.

[491] Li JM, Qiu T. Microwave dielectric properties of $\mathrm{Nd}\left[\left(\mathrm{Zn}_{1-x} \mathrm{Co}_{x}\right)_{0.5} \mathrm{Ti}_{0.5}\right] \mathrm{O}_{3}(0.025 \leqslant x \leqslant 0.1)$ ceramics. Ceram Int 2012, 38: 2597-2600.

[492] Li JM, Fan CG, Cheng ZX, et al. Influence of Zn nonstoichiometry on the phase structure, microstructure and microwave dielectric properties of $\mathrm{Nd}\left(\mathrm{Zn}_{0.5} \mathrm{Ti}_{0.5}\right) \mathrm{O}_{3}$ ceramics. J Alloys Compd 2019, 793: 385-392.

[493] Cao ZK, Xiao EC, Li XH, et al. Lattice vibrational characteristics, crystal structures and dielectric properties of non-stoichiometric $\mathrm{Nd}_{(1+x)}\left(\mathrm{Mg}_{1 / 2} \mathrm{Sn}_{1 / 2}\right) \mathrm{O}_{3}$ ceramics. $J$ Materiomics 2020, 6: 476-484.

[494] Shi F, Xiao EC, Chen GH, et al. Lattice vibrational characteristics and structures-properties relationships of non-stoichiometric $\mathrm{Nd}\left[\mathrm{Mg}_{0.5} \mathrm{Sn}_{0.5(1+x)}\right] \mathrm{O}_{3}$ ceramics. Appl Phys A 2020, 126: 1-14.

[495] Chen YC, Wang YN, Lee WC. Microstructures and microwave dielectric properties of $\mathrm{La}_{1-x} \mathrm{~B}_{x}\left(\mathrm{Mg}_{0.5} \mathrm{Sn}_{0.5}\right) \mathrm{O}_{3}$ ceramics. Curr Appl Phys 2012, 12: 726-731.

[496] Chen YC. Improved microwave dielectric properties of $\mathrm{La}\left(\mathrm{Mg}_{0.5} \mathrm{Sn}_{0.5}\right) \mathrm{O}_{3}$ ceramics with $\mathrm{Yb}^{3+}$ doping. Int $J$ Appl Ceram Technol 2012, 9: 606-614.

[497] Wang YN, Chen MD. Improved microwave dielectric properties of $\mathrm{La}\left(\mathrm{Mg}_{0.5} \mathrm{Sn}_{0.5}\right) \mathrm{O}_{3}$ ceramic with $\mathrm{Ba}^{2+}$ substitution. J Mater Sci: Mater Electron 2013, 24: 3730-3735.

[498] Remya GR, Dhwajam DB, Thomas JK, et al. Dielectric and optical properties of $\mathrm{ZnO}$ and $\mathrm{Eu}_{2} \mathrm{O}_{3}$ doped $\operatorname{Pr}_{0.22} \mathrm{Y}_{0.78} \mathrm{TiTaO}_{6}$ ceramic. J Mater Sci: Mater Electron 2012, 23: 370-375.

[499] Chen YY, Chen YC, Chen MD. Tuning the microwave dielectric properties of $\mathrm{La}\left(\mathrm{Mg}_{0.4} \mathrm{Sr}_{0.1} \mathrm{Sn}_{0.5}\right) \mathrm{O}_{3}$ by introducing $\mathrm{Ca}_{0.8} \mathrm{Sr}_{0.2} \mathrm{TiO}_{3}$. J Mater Sci: Mater Electron 2013, 24: 3126-3131.

[500] Tseng CF, Huang CC. Microwave dielectric properties of $(1-x) \mathrm{Nd}\left(\mathrm{Co}_{1 / 2} \mathrm{Ti}_{1 / 2}\right) \mathrm{O}_{3}-x\left(\mathrm{Ca}_{0.8} \mathrm{Sr}_{0.2}\right) \mathrm{TiO}_{3}$ composite ceramics. J Mater Sci 2012, 47: 3982-3988.

[501] Wang YN, Chen MD. Improved microwave dielectric properties of $\mathrm{La}\left(\mathrm{Mg}_{0.5} \mathrm{Sn}_{0.5}\right) \mathrm{O}_{3}$ ceramic with $\mathrm{Sr}^{2+}$ Substitution. Ferroelectr Lett Sect 2013, 40: 121-129.

[502] Li JM, Qiu T. Microwave dielectric properties of $(1-x) \mathrm{Ca}_{0.6} \mathrm{La}_{0.267} \mathrm{TiO}_{3}-x \mathrm{Ca}\left(\mathrm{Sm}_{0.5} \mathrm{Nb}_{0.5}\right) \mathrm{O}_{3} \quad$ ceramics. Ceram Int 2012, 38: 4331-4335.

[503] Fan J, Zhao Q, Du K, et al. Lattice structure and microwave dielectric properties of $\mathrm{La}\left[\mathrm{Al}_{1-x}\left(\mathrm{Mg}_{0.5} \mathrm{Ti}_{0.5}\right)_{x}\right] \mathrm{O}_{3}(x=0-0.2)$-based ceramics. $J$ Am Ceram Soc 2020, 103: 3231-3237.

[504] Yang HC, Zhang SR, Yang HY, et al. Vibrational spectroscopic and crystal chemical analyses of double perovskite $\mathrm{Y}_{2} \mathrm{MgTiO}_{6}$ microwave dielectric ceramics. $J$ Am Ceram Soc 2020, 103: 1121-1130.

[505] Chen CT, Huang CY, Lin YM, et al. Structure and microwave dielectric property relations in Barium cobalt magnesium niobate ceramics. Jpn J Appl Phys 2011, 50: 091503.

[506] Wang SF, Wang YR, Liu CY, et al. Microwave dielectric properties of multi-ions $\mathrm{Ba}(\mathrm{Zn}, \mathrm{Ta}) \mathrm{O}_{3}$-based perovskite ceramics. Ceram Int 2012, 38: 1127-1132.

[507] Ning PF, Li LX, Zhang P, et al. Raman scattering, electronic structure and microwave dielectric properties of $\mathrm{Ba}\left(\left[\mathrm{Mg}_{1-x} \mathrm{Zn}_{x}\right]_{1 / 3} \mathrm{Ta}_{2 / 3}\right) \mathrm{O}_{3}$ ceramics. Ceram Int 2012, 38: 1391-1398.

[508] Chen CT, Huang CY, Lin HJ, et al. Effect of small amount of cobalt substitution on structure and microwave dielectric properties of Barium magnesium niobate ceramics. J Eur Ceram Soc 2012, 32: 2373-2380.

[509] Sun TL, Li L, Mao MM, et al. Effects of postdensification annealing on microwave dielectric properties of $\mathrm{Ba}\left(\left[\mathrm{Mg}_{1-x} \mathrm{Co}_{x}\right]_{1 / 3} \mathrm{Nb}_{2 / 3}\right) \mathrm{O}_{3}$ ceramics. Int $J$ Appl Ceram Technol 2013, 10: E210-E218.

[510] Ma PP, Yi L, Liu XQ, et al. Effects of postdensification annealing upon microstructures and microwave dielectric characteristics in $\mathrm{Ba}\left(\left(\mathrm{Co}_{0.6-x / 2} \mathrm{Zn}_{0.4-x / 2} \mathrm{Mg}_{x}\right)_{1 / 3} \mathrm{Nb}_{2 / 3}\right) \mathrm{O}_{3}$ ceramics. J Am Ceram Soc 2013, 96: 3417-3424.

[511] Ma PP, Yi L, Liu XQ, et al. Effects of Mg substitution on order/disorder transition, microstructure, and microwave dielectric characteristics of $\mathrm{Ba}\left(\left(\mathrm{Co}_{0.6} \mathrm{Zn}_{0.4}\right)_{1 / 3} \mathrm{Nb}_{2 / 3}\right) \mathrm{O}_{3}$ complex perovskite ceramics. J Am Ceram Soc 2013, 96: 1795-1800.

[512] Diao CL, Shi F. Effect of sintering temperature on dielectric properties, vibrational modes and crystal structures of $\mathrm{Ba}\left[\left(\mathrm{Ni}_{0.7} \mathrm{Zn}_{0.3}\right)_{1 / 3} \mathrm{Nb}_{2 / 3}\right] \mathrm{O}_{3}$ ceramics. J Mater Sci 2012, 47: 5438-5445.

[513] Wang J, Lu WZ, Lei W. Effects of Ba deficiency on ion ordering, grain growth, and microwave dielectric properties of $\mathrm{Ba}_{1-x} \mathrm{Zn}_{1 / 3} \mathrm{Nb}_{2 / 3} \mathrm{O}_{3}$ ceramics. Jpn J Appl Phys 2012, 51: 041501 .

[514] Diao CL, Shi F. Correlation among dielectric properties, vibrational modes, and crystal structures in $\mathrm{Ba}\left[\mathrm{Sn}_{x} \mathrm{Zn}_{(1-x) / 3} \mathrm{Nb}_{2(1-x) / 3}\right] \mathrm{O}_{3}$ solid solutions. J Phys Chem C 2012, 116: 6852-6858.

[515] Shi F, Diao CL. Evaluation of dielectric properties, vibration modes, and crystal structures in $\mathrm{Ba}\left[\mathrm{Zn}_{1-x / 3} \mathrm{Ni}_{x / 3} \mathrm{Nb}_{2 / 3}\right] \mathrm{O}_{3}$ ceramics. Metall Mater Trans $A$ 2013, 44: 381-387.

[516] Fu MS, Ni L, Chen XM. Abnormal variation of microwave dielectric properties in $\mathrm{A} / \mathrm{B}$ site co-substituted $\left(\mathrm{Ca}_{1-0.3 x} \mathrm{La}_{0.2 x}\right)\left[\left(\mathrm{Mg}_{1 / 3} \mathrm{Ta}_{2 / 3}\right)_{1-x} \mathrm{Ti}_{x}\right] \mathrm{O}_{3}$ complex perovskite ceramics. J Eur Ceram Soc 2013, 33: 813-823.

[517] Sun TL, Mao MM, Chen XM. Structure and microwave dielectric properties of $\mathrm{Ba}\left[\left(\mathrm{Mg}_{1-x} \mathrm{Ni}_{x}\right)_{1 / 3} \mathrm{Nb}_{2 / 3}\right] \mathrm{O}_{3}$ ceramics. Mater Res Bull 2015, 72: 291-298.

[518] Sindam B, James Raju KC. Influence of sintering temperature on microwave dielectric properties, structure and lattice modes of $\mathrm{Ba}\left(\mathrm{Zn}_{1 / 3} \mathrm{Ta}_{2 / 3}\right) \mathrm{O}_{3}$ resonators. J Mater Sci: Mater Electron 2015, 26: 3997-4004.

[519] Sun TL, Zhao YF, Chen XM. Improvement of microwave dielectric properties for $\mathrm{Ba}\left(\mathrm{Ni}_{1 / 3} \mathrm{Nb}_{2 / 3}\right) \mathrm{O}_{3}$ ceramics by 
Zr-substitution. Ceram Int 2015, 41: 5872-5880.

[520] Sun TL, Chen XM. Tailoring the order-disorder transition and microwave dielectric properties of $\mathrm{Ba}\left[\left(\mathrm{Ni}_{0.6} \mathrm{Zn}_{0.4}\right)_{1 / 3} \mathrm{Nb}_{2 / 3}\right] \mathrm{O}_{3}$ ceramics by $\mathrm{Mg}$-substitution. Mater Chem Phys 2015, 165: 142-149.

[521] Wang ZF, Huang BY, Wang LX, et al. Low loss $\left(\mathrm{Ba}_{1-x} \mathrm{Sr}_{x}\right)\left(\mathrm{Co}_{1 / 3} \mathrm{Nb}_{2 / 3}\right) \mathrm{O}_{3}$ solid solution: Phase evolution, microstructure and microwave dielectric properties. $J$ Mater Sci: Mater Electron 2015, 26: 4273-4279.

[522] Zhou XH, Zhang YQ, Yang XS, et al. Effects of $\mathrm{Y}_{2} \mathrm{O}_{3}$ substitution on microwave dielectric properties of $\mathrm{Ba}\left(\mathrm{Co}_{0.6} \mathrm{Zn}_{0.38}\right)_{1 / 3} \mathrm{Nb}_{2 / 3} \mathrm{O}_{3}$ ceramics. J Mater Sci: Mater Electron 2015, 26: 7683-7689.

[523] Zhang YQ, Zhou XH, Yang XS, et al. Effects of $\mathrm{Y}_{2} \mathrm{O}_{3} / \mathrm{CeO}_{2}$ co-doping on microwave dielectric properties of $\mathrm{Ba}\left(\mathrm{Co}_{0.6} \mathrm{Zn}_{38}\right)_{1 / 3} \mathrm{Nb}_{2 / 3} \mathrm{O}_{3}$ ceramics. J Alloys Compd 2016, 679: $247-253$.

[524] Rodrigues JEFS, Castro PJ, Pizani PS, et al. Structural ordering and dielectric properties of $\mathrm{Ba}_{3} \mathrm{CaNb}_{2} \mathrm{O}_{9}$-based microwave ceramics. Ceram Int 2016, 42: 18087-18093.

[525] Ni LZ, Li LX, Du MK. Ultra-high- $Q$ and wide temperature stable $\mathrm{Ba}\left(\mathrm{Mg}_{1 / 3} \mathrm{Ta}_{x}\right) \mathrm{O}_{3}$ microwave dielectric ceramic for 5G-oriented dielectric duplexer adhibition. $J$ Alloys Compd 2020, 844: 156106.

[526] Jinga SI, Stoleriu S, Busuioc C. Microwave dielectric properties of $\mathrm{Ba}\left(\mathrm{Zn}_{1 / 3} \mathrm{Ta}_{2 / 3}\right) \mathrm{O}_{3}$ ceramics doped with $\mathrm{Nb}_{2} \mathrm{O}_{5}$, $\mathrm{MnO}_{2}$ or $\mathrm{V}_{2} \mathrm{O}_{3}$. Mater Res Bull 2012, 47: 3713-3718.

[527] Wang ZF, Huang BY, Wang LX, et al. Sintering characteristics and microwave dielectric properties of $\mathrm{Ba}\left(\mathrm{Co}_{1 / 3} \mathrm{Nb}_{2 / 3}\right) \mathrm{O}_{3}-\mathrm{MnO}_{2}$ ceramics. J Mater Sci: Mater Electron 2015, 26: 1107-1112.

[528] Tang B, Fang ZX, Li YX, et al. Microwave dielectric properties of $\mathrm{Ba}\left(\mathrm{Co}_{0.56} \mathrm{Y}_{0.04} \mathrm{Zn}_{0.35}\right)_{1 / 3} \mathrm{Nb}_{2 / 3+x} \mathrm{O}_{3}(x=-0.004 \sim$ 0.008) ceramics. J Mater Sci: Mater Electron 2015, 26: 6585-6591.

[529] Sindam B, James Raju KC. Microwave dielectric properties of $\mathrm{Ba}\left(\mathrm{Zn}_{1 / 3} \mathrm{Ta}_{2 / 3}\right) \mathrm{O}_{3}$ for application in high power waveguide window. Eur Phys J B 2016, 89: 92.

[530] Peng S, Xu JM, Li H. Microstructure and microwave dielectric properties of $\mathrm{Ba}\left(\left[\mathrm{Mg}_{1-x} \mathrm{Zn}_{x}\right]_{1 / 3} \mathrm{Ta}_{2 / 3}\right) \mathrm{O}_{3}$ solid solution ceramics. J Mater Sci: Mater Electron 2020, 31: 20423-20430.

[531] Peng $\mathrm{S}, \mathrm{Wu} \mathrm{MQ}, \mathrm{Xu} J \mathrm{M}$, et al. Effect of $\mathrm{La}_{2} \mathrm{O}_{3}$ addition on the microwave dielectric properties of $\mathrm{Ba}\left(\mathrm{Mg}_{1 / 3} \mathrm{Ta}_{2 / 3}\right) \mathrm{O}_{3}$ ceramics. J Mater Sci: Mater Electron 2017, 28: 3349-3355.

[532] Peng $\mathrm{S}, \mathrm{Xu}$ JM, Li F. Influence of $\mathrm{Ca}^{2+}$ substitution for $\mathrm{Ba}^{2+}$ on the crystal structure and microwave dielectric properties of $\mathrm{Ba}_{1-x} \mathrm{Ca}_{x}\left(\mathrm{Mg}_{1 / 3} \mathrm{Ta}_{2 / 3}\right) \mathrm{O}_{3}$ ceramics. J Mater Sci: Mater Electron 2020, 31: 15822-15828.

[533] Peng S, Wu MQ, Xu JM, et al. Microwave dielectric properties of $\mathrm{Ba}\left[\mathrm{Mg}_{1-x / 3} \mathrm{Sn}_{x} \mathrm{Ta}_{2(1-x) / 3}\right] \mathrm{O}_{3} \quad(x=0-0.25)$ ceramics. J Mater Sci: Mater Electron 2017, 28: 174-179.

[534] Ni LZ, Li LX, Du MK, et al. Wide temperature stable $\mathrm{Ba}\left(\mathrm{Mg}_{x} \mathrm{Ta}_{2 / 3}\right) \mathrm{O}_{3}$ microwave dielectric ceramics with ultra-high- $Q$ applied for $5 \mathrm{G}$ dielectric filter. Ceram Int 2021, 47: 1034-1039.

[535] Guevarra J, van Smaalen S, Rotiroti N, et al. Crystal structure of $\mathrm{Ca}_{5} \mathrm{Nb}_{5} \mathrm{O}_{17} . J$ Solid State Chem 2005, 178: 2934-2941.

[536] Joseph T, Anjana PS, Letourneau S, et al. Structure and microwave dielectric properties of $\mathrm{Ca}_{5} \mathrm{~A}_{4} \mathrm{TiO}_{17}(\mathrm{~A}=\mathrm{Nb}$, Ta) ceramics. Mater Chem Phys 2010, 121: 77-82.

[537] Manan A, Iqbal Y. Influence of Sm substitution on the phase, microstructure and microwave dielectric properties of $\mathrm{SrLa}_{4} \mathrm{Ti}_{5} \mathrm{O}_{17}$. J Mater Sci: Mater Electron 2011, 22: 1848-1854.

[538] Iqbal $\mathrm{Y}$, Manan A, Reaney IM. Low loss $\mathrm{Sr}_{1-x} \mathrm{Ca}_{x} \mathrm{La}_{4} \mathrm{Ti}_{5} \mathrm{O}_{17}$ microwave dielectric ceramics. Mater Res Bull 2011, 46: 1092-1096.

[539] Iqbal Y, Manan A. Phase, microstructure and microwave dielectric properties of $\mathrm{Zr}$-doped $\mathrm{SrLa}_{4} \mathrm{Ti}_{5-x} \mathrm{Zr}_{x} \mathrm{O}_{17} . J$ Mater Sci: Mater Electron 2012, 23: 536-541.

[540] Li CC, Wei XY, Yan HX, et al. Microwave dielectric properties of $\mathrm{CaO}-\mathrm{La}_{2} \mathrm{O}_{3}-\mathrm{Nb}_{2} \mathrm{O}_{5}-\mathrm{TiO}_{2}$ ceramics. J Mater Sci: Mater Electron 2013, 24: 1947-1954.

[541] Li CC, Wei XY, Yan HX, et al. Microwave dielectric properties of $\mathrm{La}_{3} \mathrm{Ti}_{2} \mathrm{TaO}_{11}$ ceramics with perovskite-like layered structure. J Eur Ceram Soc 2012, 32: 4015-4020.

[542] Manan A, Reaney IM. The effect of processing conditions on the phase, microstructure and dielectric properties of $\mathrm{SrCa}_{4} \mathrm{Nb}_{4} \mathrm{TiO}_{17}$ and $\mathrm{Ca}_{5} \mathrm{Nb}_{4} \mathrm{TiO}_{17}$ microwave ceramics. Mater Sci Pol 2012, 30: 98-104.

[543] Iqbal Y, Muhammad R. Phase, microstructure, and microwave dielectric properties of $\mathrm{NaCa}_{4-x} \mathrm{Sr}_{x} \mathrm{Nb}_{5} \mathrm{O}_{17}(x=$ 0 to 4) ceramics. J Electron Mater 2013, 42: 452-457.

[544] Muhammad R, Iqbal Y. Preparation and characterization of K-substituted $\mathrm{NaCa}_{4} \mathrm{Nb}_{5} \mathrm{O}_{17}$ microwave dielectric ceramics. J Mater Sci: Mater Electron 2013, 24: 2322-2326.

[545] Rejini R, Subodh G, Sebastian MT. $\mathrm{Ca}_{4} \mathrm{La}_{2} \mathrm{Ti}_{5} \mathrm{O}_{17}$ : A novel low loss dielectric ceramics in the $\mathrm{CaO}-\mathrm{La}_{2} \mathrm{O}_{3}-\mathrm{TiO}_{2}$ system. J Mater Sci: Mater Electron 2008, 19: 1153-1155.

[546] Chen GH, Di JC, Xu HR, et al. Microwave dielectric properties of $\mathrm{Ca}_{4} \mathrm{La}_{2} \mathrm{Ti}_{5-x}\left(\mathrm{Mg}_{1 / 3} \mathrm{Nb}_{2 / 3}\right)_{x} \mathrm{O}_{17}$ ceramics. $J$ Am Ceram Soc 2012, 95: 1394-1397.

[547] Di JC, Chen GH, Hou MZ, et al. Low loss and middle permittivity of $(1-x) \mathrm{Ca}_{4} \mathrm{La}_{2} \mathrm{Ti}_{5} \mathrm{O}_{17-x} \mathrm{NdAlO}_{3}$ dielectric resonators with near-zero temperature coefficient of the resonant frequency. J Mater Sci 2012, 47: 2271-2277.

[548] Chen GH, Di JC, Li M, et al. Synthesis, microstructure and microwave dielectric properties of $\mathrm{Ca}_{4-x} \mathrm{Mg}_{x} \mathrm{La}_{2} \mathrm{Ti}_{5} \mathrm{O}_{17}$ ceramics. J Mater Sci: Mater Electron 2012, 23: 746-752.

[549] Fang L, Li CC, Peng XY, et al. $\mathrm{Sr}_{4-m} \mathrm{La}_{m} \mathrm{Ti}_{m-1} \mathrm{Ta}_{4-m} \mathrm{O}_{12}$ $(m=1,2,3)$ : A novel series of $\mathrm{A}_{4} \mathrm{~B}_{3} \mathrm{O}_{12}$-type microwave ceramics with a high Q and low $\tau_{\mathrm{f}} . J$ Am Ceram Soc 2010, 93: 1884-1887.

[550] Fang L, Li CC, Peng XY, et al. Two novel $\mathrm{A}_{4} \mathrm{~B}_{3} \mathrm{O}_{12}$-type microwave ceramics with high- $Q$ and near-zero $\tau_{\mathrm{f}} . J$ Mater Res 2010, 25: 1239-1242. 
[551] Suresh MK, John A, Thomas JK, et al. Structural, spectroscopic and dielectric investigations on $\mathrm{Ba}_{8} \mathrm{Zn}\left(\mathrm{Nb}_{6-x} \mathrm{Sb}_{x}\right) \mathrm{O}_{24}$ microwave ceramics. Mater Res Bull 2010, 45: 1389-1395.

[552] Suresh MK, John A, Thomas JK, et al. Structural analysis and properties of thermally stable $\mathrm{Ba}_{8} \mathrm{Mg}\left(\mathrm{Nb}_{6-x} \mathrm{Sb}_{x}\right) \mathrm{O}_{24}$ microwave ceramics. J Alloys Compd 2011, 509: 2401-2406.

[553] Solomon S, Suresh MK, Thomas JK, et al. Synthesis, structural analysis and dielectric properties of $\mathrm{Ba}_{8}\left(\mathrm{Mg}_{1-x} \mathrm{Zn}_{x}\right) \mathrm{Nb}_{6} \mathrm{O}_{24}$ hexagonal perovskites. Ceram Int 2012, 38: 6487-6494.

[554] Fang L, Su CX, Wei ZH, et al. Phase structure, band gap and microwave dielectric properties of $\mathrm{Ba}_{8} \mathrm{Ti}_{3} \mathrm{Nb}_{4-x} \mathrm{Sb}_{x} \mathrm{O}_{24}$ ceramics. Ceram Int 2013, 39: 579-583.

[555] Tian CL, Yue ZX, Zhou YY. Microstructures and microwave dielectric properties of $\mathrm{Ba}_{4} \mathrm{LiNb}_{3} \mathrm{O}_{12}-\mathrm{BaWO}_{4}$ composite ceramics. Mater Sci Eng: B 2013, 178: 178-182.

[556] Zhou HF, Liu XB, Chen XL, et al. $\mathrm{Ba}_{4} \mathrm{LiNb}_{3-x} \mathrm{Sb}_{x} \mathrm{O}_{12}$ : Phase evolution, microstructure and optimized microwave dielectric properties. Mater Lett 2013, 96: 199-202.

[557] Tang Y, Fang WS, Fang L, et al. Phase transformation and microwave dielectric properties of $\mathrm{Ba}_{4} \mathrm{LiTa}_{3-x} \mathrm{Sb}_{x} \mathrm{O}_{12}$. Ceram Int 2015, 41: 6653-6656.

[558] Liao W, Fang L, Xiang F, et al. Effect of $\mathrm{Sb}^{5+}$ substitution on the dielectric properties of $\mathrm{Ba}_{3} \mathrm{LiTa}_{3} \mathrm{Ti}_{5} \mathrm{O}_{21}$ ceramics. $J$ Mater Sci: Mater Electron 2013, 24: 272-276.

[559] Fang L, Liao W, Wu MX, et al. Microwave dielectric properties of $\mathrm{Ba}_{3} \mathrm{LiNb}_{3-x} \mathrm{Sb}_{x} \mathrm{Ti}_{5} \mathrm{O}_{21}(x=0-3)$ ceramics. Mater Lett 2012, 76: 73-76.

[560] Fang L, Wu MX, Liu QW, et al. High $\varepsilon_{\mathrm{r}}$ and low loss microwave dielectric ceramics $\mathrm{Ba}_{3} \mathrm{LiNb}_{3-x} \mathrm{Ta}_{x} \mathrm{Ti}_{5} \mathrm{O}_{21}$. Mater Chem Phys 2012, 136: 599-603.

[561] Wang KG, Zhou HF, Luan XW, et al. Microwave dielectric properties of $\mathrm{LiSmTa}_{4} \mathrm{O}_{12}$ ceramics with A-site deficient perovskite structure. Mater Lett 2020, 274: 128020.

[562] Fan XC, Chen XM, Liu XQ. Structural dependence of microwave dielectric properties of $\mathrm{SrRAlO}_{4}(\mathrm{R}=\mathrm{Sm}, \mathrm{Nd}$, La) ceramics: Crystal structure refinement and infrared reflectivity study. Chem Mater 2008, 20: 4092-4098.

[563] Fan XC, Mao MM, Chen XM. Microstructures and microwave dielectric properties of the $\mathrm{CaSmAlO}_{4}$-based ceramics. J Am Ceram Soc 2008, 91: 2917-2922.

[564] Yuan HX, Chen XM, Mao MM. Structure and microwave dielectric characteristics of $\mathrm{Ca}_{1+x} \mathrm{Nd}_{1-x} \mathrm{Al}_{1-x} \mathrm{Ti}_{x} \mathrm{O}_{4}$ ceramics. J Am Ceram Soc 2009, 92: 2286-2290.

[565] Mao MM, Fan XC, Chen XM. Effect of A-site ionic radius on the structure and microwave dielectric characteristics of $\mathrm{Sr}_{1+x} \mathrm{Sm}_{1-x} \mathrm{Al}_{1-x} \mathrm{Ti}_{x} \mathrm{O}_{4}$ ceramics. Int $J$ Appl Ceram Technol 2010, 7: E156-E162.

[566] Zhang C, Yi L, Chen XM. Improvement of microwave dielectric characteristics in $\mathrm{SrNdAlO}_{4}$ ceramics by Ca-substitution. Ceram Int 2014, 40: 6077-6082.

[567] Xiao Y, Chen XM, Liu XQ. Microstructures and microwave dielectric characteristics of $\mathrm{CaRAlO}_{4}(\mathrm{R}=\mathrm{Nd}$, $\mathrm{Sm}, \mathrm{Y}$ ) ceramics with tetragonal $\mathrm{K}_{2} \mathrm{NiF}_{4}$ structure. $J \mathrm{Am}$ Ceram Soc 2004, 87: 2143-2146.

[568] Mao MM, Chen XM. Infrared reflectivity spectra and microwave dielectric properties of $\left(\mathrm{Sr}_{1-x} \mathrm{Ca}_{x}\right) \mathrm{SmAlO}_{4}$ $(0 \leqslant x \leqslant 1)$ ceramics. Int J Appl Ceram Technol 2011, 8: 1023-1030.

[569] Mao MM, Chen XM, Liu XQ. Structure and microwave dielectric properties of solid solution in $\mathrm{SrLaAlO}_{4}-$ $\mathrm{Sr}_{2} \mathrm{TiO}_{4}$ system. J Am Ceram Soc 2011, 94: 3948-3952.

[570] Mao MM, Liu XQ, Chen XM. Structural evolution and its effects on dielectric loss in $\mathrm{Sr}_{1+x} \mathrm{Sm}_{1-x} \mathrm{Al}_{1-x} \mathrm{Ti}_{x} \mathrm{O}_{4}$ microwave dielectric ceramics. J Am Ceram Soc 2011, 94: 2506-2511.

[571] Liu B, Yi L, Liu XQ, et al. Structure and microwave dielectric properties of $\mathrm{SrSmAlO}_{4}-\mathrm{Sr}_{2} \mathrm{TiO}_{4}$ solid solutions. J Electroceramics 2015, 34: 114-121.

[572] Liu B, Li L, Liu XQ, et al. Structural evolution of $\mathrm{SrLaAl}_{1-x}\left(\mathrm{Zn}_{0.5} \mathrm{Ti}_{0.5}\right)_{x} \mathrm{O}_{4}$ ceramics and effects on their microwave dielectric properties. J Mater Chem C 2016, 4: 4684-4691.

[573] Ren GR, Zhu JY, Li L, et al. $\mathrm{SrLa}\left(\mathrm{R}_{0.5} \mathrm{Ti}_{0.5}\right) \mathrm{O}_{4}(\mathrm{R}=\mathrm{Mg}$, $\mathrm{Zn)}$ microwave dielectric ceramics with complex $\mathrm{K}_{2} \mathrm{NiF}_{4}$-type layered perovskite structure. J Am Ceram Soc 2017, 100: 2582-2589.

[574] Yan H, Chen GY, Li L, et al. Microwave dielectric properties of $\mathrm{SrLa}\left[\mathrm{Ga}_{1-x}\left(\mathrm{Mg}_{0.5} \mathrm{Ti}_{0.5}\right)_{x}\right] \mathrm{O}_{4} \quad$ and $\mathrm{SrLa}\left[\mathrm{Ga}_{1-x}\left(\mathrm{Zn}_{0.5} \mathrm{Ti}_{0.5}\right)_{x}\right] \mathrm{O}_{4}(x=0.2-0.8)$ ceramics. Int $J$ Appl Ceram Technol 2020, 17: 790-796.

[575] Manan A, Ullah R, Iqbal Y, et al. Tailoring the microwave dielectric properties of $\mathrm{Sr}_{0.6} \mathrm{Ca}_{0.4} \mathrm{LaAlO}_{4}$ ceramic by $\mathrm{TiO}_{2}$ addition. J Aust Ceram Soc 2020, 56: 1013-1019.

[576] Liu B, Li L, Liu XQ, et al. $\operatorname{Sr}_{n+1} \operatorname{Ti}_{n} \mathrm{O}_{3 n+1}(n=1,2)$ microwave dielectric ceramics with medium dielectric constant and ultra-low dielectric loss. J Am Ceram Soc 2017, 100: 496-500.

[577] Yuan ZQ, Liu B, Liu XQ, et al. Structure and microwave dielectric characteristics of $\mathrm{Sr}\left(\mathrm{La}_{1-x} \mathrm{Sm}_{x}\right)_{2} \mathrm{Al}_{2} \mathrm{O}_{7}$ ceramics. RSC Adv 2016, 6: 96229-96236.

[578] Liu B, Liu XQ, Chen XM. Sr $\mathrm{LaAlTiO}_{7}$ : A new Ruddlesden-Popper compound with excellent microwave dielectric properties. J Mater Chem C 2016, 4: 17201726.

[579] Yi L, Li L, Liu XQ, et al. Structure evolution and enhanced microwave dielectric characteristics of $\left(\mathrm{Sr}_{1-x} \mathrm{Ca}_{x}\right) \mathrm{La}_{2} \mathrm{Al}_{2} \mathrm{O}_{7}$ ceramics. J Am Ceram Soc 2014, 97: 3531-3536.

[580] Yi L, Liu XQ, Li L, et al. $\mathrm{SrLn}_{2} \mathrm{Al}_{2} \mathrm{O}_{7}(\mathrm{Ln}=\mathrm{La}, \mathrm{Nd}, \mathrm{Sm})$ microwave dielectric ceramic new materials. Int $J$ Appl Ceram Technol 2013, 10: E177-E185.

[581] Dias A, Viegas JI, Moreira RL. Synthesis and $\mu$-Raman scattering of Ruddlesden-Popper ceramics $\mathrm{Sr}_{3} \mathrm{Ti}_{2} \mathrm{O}_{7}$, $\mathrm{SrLa}_{2} \mathrm{Al}_{2} \mathrm{O}_{7}$ and $\mathrm{Sr}_{2} \mathrm{LaAlTiO}_{7}$. J Alloys Compd 2017, 725: 77-83.

[582] Hameed I, Liu B, Li L, et al. $\left(\mathrm{Sr}_{1-x} \mathrm{Ca}_{x}\right)_{2} \mathrm{TiO}_{4}$ microwave 
dielectric ceramics with R-P structure $(x=0-0.15)$. Int $J$ Appl Ceram Technol 2019, 16: 2040-2046.

[583] Liu B, Huang YH, Song KX, et al. Structural evolution and microwave dielectric properties in $\mathrm{Sr}_{2}\left(\mathrm{Ti}_{1-x} \mathrm{Sn}_{x}\right) \mathrm{O}_{4}$ ceramics. J Eur Ceram Soc 2018, 38: 3833-3839.

[584] Hameed I, Wu SY, Li L, et al. Structure and microwave dielectric characteristics of $\mathrm{Sr}_{2}\left[\mathrm{Ti}_{1-x}\left(\mathrm{Al}_{0.5} \mathrm{Nb}_{0.5}\right)_{x}\right] \mathrm{O}_{4}(x \leqslant$ 0.50) ceramics. J Am Ceram Soc 2019, 102: 6137-6146.

[585] Xie MQ, Song XQ, Du K, et al. Improved microwave dielectric properties of the $\left(\mathrm{Sr}_{1-3 x / 2} \mathrm{La}_{x}\right)_{2} \mathrm{Ti}_{1-y} \mathrm{Ce}_{y} \mathrm{O}_{4}$ ceramics. J Mater Sci: Mater Electron 2020, 31: 13541-13548.

[586] Dai QL, Zuo RZ. A novel ultralow-loss $\mathrm{Sr}_{2} \mathrm{CeO}_{4}$ microwave dielectric ceramic and its property modification. J Eur Ceram Soc 2019, 39: 1132-1136.

[587] Wang Y, Tang TL, Li MX, et al. $\mathrm{Ce}_{0.75} \mathrm{Y}_{0.25} \mathrm{O}_{1.875}$ : New temperature-stable microwave dielectric ceramics with high Q values for microwave application. Ceram Int 2020, 46: 6984-6986.

[588] Ullah A, Liu HX, Manan A, et al. Microwave dielectric properties of $\mathrm{Bi}_{2}\left(\mathrm{Li}_{0.5} \mathrm{Ta}_{1.5}\right) \mathrm{O}_{7}-\mathrm{TiO}_{2}$-based ceramics for $5 \mathrm{G}$ cellular base station resonator application. Ceram Int 2021, 47: 8416-8423.

[589] Wang ZJ, Chen Y. Structures and microwave dielectric properties of Ti-doped $\mathrm{CeO}_{2}$ ceramics with a near-zero temperature coefficient of resonant frequency. $J$ Alloys Compd 2021, 854: 157270.

[590] Du C, Guo HH, Zhou D, et al. Dielectric resonator antennas based on high quality factor $\mathrm{MgAl}_{2} \mathrm{O}_{4}$ transparent dielectric ceramics. J Mater Chem C 2020, 8: 14880-14885.

[591] Qin TY, Zhong CW, Qin Y, et al. The structure evolution and microwave dielectric properties of $\mathrm{MgAl}_{2-x}\left(\mathrm{Mg}_{0.5} \mathrm{Ti}_{0.5}\right)_{x} \mathrm{O}_{4}$ solid solutions. Ceram Int 2020, 46: 19046-19051.

[592] Liu B, Song KX. Vibrational spectroscopy and microwave dielectric properties of two novel $\mathrm{Ca}_{3} \mathrm{Ln}_{2} \mathrm{~W}_{2} \mathrm{O}_{12}(\mathrm{Ln}=\mathrm{La}$, Sm) tungstate ceramics. Mater Res Bull 2021, 133: 111022.

[593] Hu S, Zhou HF, Zhou XJ, et al. Phase structure, sintering behaviour and microwave dielectric properties of $\mathrm{Ln}_{2} \mathrm{MoO}_{6}(\mathrm{Ln}=\mathrm{La}$ and $\mathrm{Y})$ ceramics. Ceram Int 2020, 46: 24552-24556.

[594] Kim E, Huang K, Jegelka S, et al. Virtual screening of inorganic materials synthesis parameters with deep learning. npj Comput Mater 2017, 3: 53.
[595] Raccuglia P, Elbert KC, Adler PDF, et al. Machinelearning-assisted materials discovery using failed experiments. Nature 2016, 533: 73-76.

[596] Weng BC, Song ZL, Zhu RL, et al. Simple descriptor derived from symbolic regression accelerating the discovery of new perovskite catalysts. Nat Commun 2020, 11: 3513 .

[597] Kim C, Pilania G, Ramprasad R. Machine learning assisted predictions of intrinsic dielectric breakdown strength of $\mathrm{ABX}_{3}$ perovskites. $J$ Phys Chem C 2016, 120: 1457514580.

[598] Xue D, Balachandran PV, Yuan R, et al. Accelerated search for $\mathrm{BaTiO}_{3}$-based piezoelectrics with vertical morphotropic phase boundary using Bayesian learning. PNAS 2016, 113: 13301-13306.

[599] Sun YT, Bai HY, Li MZ, et al. Machine learning approach for prediction and understanding of glass-forming ability. J Phys Chem Lett 2017, 8: 3434-3439.

[600] Kim C, Pilania G, Ramprasad R. From organized high-throughput data to phenomenological theory using machine learning: The example of dielectric breakdown. Chem Mater 2016, 28: 1304-1311.

[601] Qin JC, Liu ZF, Ma MS, et al. Machine learning approaches for permittivity prediction and rational design of microwave dielectric ceramics. J Materiomics 2021, https://doi.org/10.1016/j.jmat.2021.02.012.

[602] Qin J, Liu Z, Ma M, et al. Structure and microwave dielectric properties of gillespite-type $\mathrm{ACuSi}_{4} \mathrm{O}_{10}(\mathrm{~A}=\mathrm{Ca}$, $\mathrm{Sr}, \mathrm{Ba}$ ) ceramics and quantitative prediction of the $Q \times f$ value via machine learning. ACS Appl Mater Interfaces 2021, 13: 17817-17826.

Open Access This article is licensed under a Creative Commons Attribution 4.0 International License, which permits use, sharing, adaptation, distribution and reproduction in any medium or format, as long as you give appropriate credit to the original author(s) and the source, provide a link to the Creative Commons licence, and indicate if changes were made.

The images or other third party material in this article are included in the article's Creative Commons licence, unless indicated otherwise in a credit line to the material. If material is not included in the article's Creative Commons licence and your intended use is not permitted by statutory regulation or exceeds the permitted use, you will need to obtain permission directly from the copyright holder.

To view a copy of this licence, visit http://creativecommons. org/licenses/by/4.0/. 